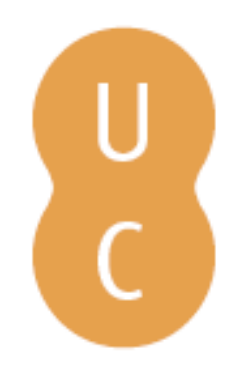

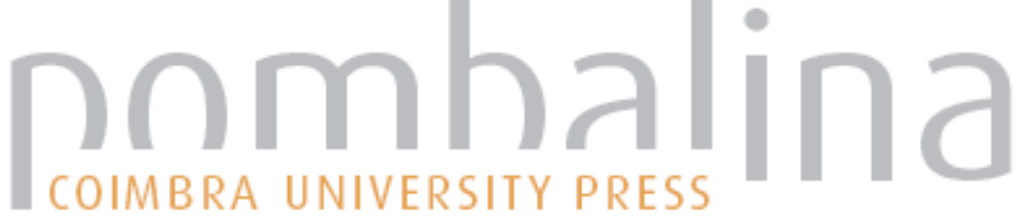

\section{Vidas Paralelas: Péricles e Fábio Máximo}

Autor(es): Plutarco

Publicado por: Imprensa da Universidade de Coimbra

URL

persistente: URI:http://hdl.handle.net/10316.2/2395

DOI: $\quad$ DOI:http://dx.doi.org/10.14195/978-989-26-0776-4

Accessed : $\quad$ 26-Apr-2023 06:48:40

A navegação consulta e descarregamento dos títulos inseridos nas Bibliotecas Digitais UC Digitalis, UC Pombalina e UC Impactum, pressupõem a aceitação plena e sem reservas dos Termos e Condições de Uso destas Bibliotecas Digitais, disponíveis em https://digitalis.uc.pt/pt-pt/termos.

Conforme exposto nos referidos Termos e Condições de Uso, o descarregamento de títulos de acesso restrito requer uma licença válida de autorização devendo o utilizador aceder ao(s) documento(s) a partir de um endereço de IP da instituição detentora da supramencionada licença.

Ao utilizador é apenas permitido o descarregamento para uso pessoal, pelo que o emprego do(s) título(s) descarregado(s) para outro fim, designadamente comercial, carece de autorização do respetivo autor ou editor da obra.

Na medida em que todas as obras da UC Digitalis se encontram protegidas pelo Código do Direito de Autor e Direitos Conexos e demais legislação aplicável, toda a cópia, parcial ou total, deste documento, nos casos em que é legalmente admitida, deverá conter ou fazer-se acompanhar por este aviso.

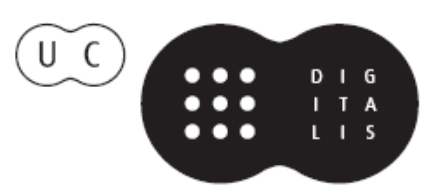




\section{Plutarco}

\section{Vidas Paralelas \\ Péricles e Fábio Máximo}

TRADUÇÃo DO GREGO, INTRODUÇÃo E NOTAS Ana Maria Guedes Ferreira e Ália Rosa Conceição Rodrigues 
(Página deixada propositadamente em branco) 


\section{Plutarco}

\section{Vidas Paralelas: \\ Péricles e Fábio Máximo}

TRADUÇÃo Do GREGo, INTRODUÇÃo E NOTAS DE

Ana Maria Guedes Ferreira

Universidade do Porto

Ália Rosa Conceiçáo Rodrigues

Universidade de Coimbra

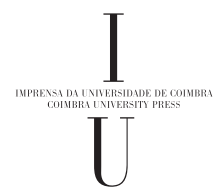


TODOS OS VOLUMES DESTA SÉRIE SÃO SUJEITOS A ARBITRAGEM CIENTÍFICA INDEPENDENTE.

Título • Vidas Paralelas - Péricles e Fábio Máximo

Tradução do grego, introdução e notas • Ana Maria Guedes Ferreira

e Ália Rosa Conceiçấo Rodrigues

Autor • Plutarco

SÉrie TeXTos

Coordenador Científico do plano de edição: Maria do Céu Fialho

Conselho Edtorial

José Ribeiro Ferreira

Francisco de Oliveira

Maria de Fátima Silva

Nair Castro Soares

Diretor Técnico da Colecção:

Delfim Leão

Obra REALIZADa No Âmbito das aCtividades da UI\&D

Centro de Estudos Clássicos e Humanísticos

EDIÇÃo

Imprensa da Universidade de Coimbra

URL: http://www.uc.pt/imprensa_uc

E-mail: imprensauc@ci.uc.pt

Vendas online:

http://livrariadaimprensa.uc.pt

CoORdenAÇÃo EDITORIAL

Imprensa da Universidade de Coimbra

Concepção gráfica e Paginação

Rodolfo Lopes, Nelson Ferreira

Pré-Impressão

Imprensa da Universidade de Coimbra

Impressấo e ACABAmento

SimỐES E LiNHARES

OBRA PUBLICADA COM O APOIO DE:
ISBN

978-989-26-0516-6

ISBN DigITAL

978-989-26-0776-4

DOI

http://dx.doi.org/10.14195/978-989-260776-4

Depósito Legal $358454 / 13$

I a EDIÇÃo: CECH • 2010

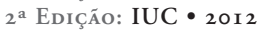

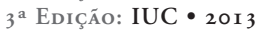

\section{FCT Fundação para a Ciência e a Tecnologia}

MINISTÉRIO DA CIÊNCIA, TECNOIOGIA E ENSINO SUPERIOR Portugal

\section{(C) Abril 2013.}

IMPRENSA dA UnIVERSIDAdE de CoImbra

Classica Digitalia Viniversitatis Conimbrigensis (http://classicadigitalia.uc.pt)

Centro de Estudos Clássicos e Humanísticos da Universidade de Coimbra

Reservados todos os direitos. Nos termos legais fica expressamente proibida a reproduçăo total ou parcial por qualquer meio, em papel ou em edição electrónica, sem autorizaçăo expressa dos titulares dos direitos. É desde já excepcionada a utilizaçăo em circuitos académicos fechados para apoio a leccionaçăo ou extensão cultural por via de $e$-learning. 


\section{ÍNDICE}

INTRODUÇÃo GERAL

Fragmentos: EDIÇÓES E RESPECTIVAS SIGLAS

VidA de PÉRICLES

INTRODUÇÃO

TÁbua cronológica Grécia/Vida de Péricles

VIDA DE PÉRICLES

Vida de FÁbio MÁximo

INTRODUÇÃO

TÁbua cronológica Roma/Vida de FÁbio Máximo

176

VIDA DE FÁBIO MÁXIMO

Comparação entre Péricles e Fábio MÁXImo

BiBLIOGRAFIA

ÍNDICES DE NoMES 
(Página deixada propositadamente em branco) 


\section{INTRODUÇÃO GERAL}

E, por isso, parece bem aprovar a frase de Bias - que o poder revelará o homem; porque o governante na sociedade está em relaçáo com o semelhante.

Aristóteles, Ética a Nicómaco (1130a 1)

O que têm, na verdade, Péricles e Fábio Máximo em comum? Assim questionou K. Zeigler ${ }^{1}$ (1951: 899), editor das Vidas Paralelas de Plutarco. Com efeito, enquanto o primeiro (495/90-429 a.C.) era líder democrático quando Atenas conhecia um tempo áureo e o imperialismo grego estava no apogeu, Fábio Máximo (ca. 283?-203 a.C.), representante da antiga aristocracia, foi eleito dictator e cinco vezes cônsul, numa altura em que Roma enfrentava a sua maior crise de sempre. A influência do político ateniense foi tal que deu nome ao período em que viveu, também designado de século de Péricles, enquanto o ditador romano recebeu a alcunha de cuntactor, "o contemporizador" pela táctica de batalha campal usada contra os Cartagineses.

1 "Was haben...Perikles und Fabius Maximus... in Wahrheit miteinander gemein?”. A mesma questão é alargada a outros pares de Vidas, como Aristides-Catão o Antigo e Timoleonte-Émilio Paulo. Crespo ( $\left.{ }^{4} 2007: 313\right)$ partilha do mesmo ponto de vista, ao sustentar que "Plutarco (...) quedó prisionero de su propio método." 
Assim, perante esta disparidade é verosímil concluir que Péricles fica visivelmente engrandecido face ao segundo elemento, não parecendo possível estabelecer um paralelo justo.

Observemos, contudo, o objectivo deste método comparativo das Vidas expresso no proémio do opúsculo plutarquiano A Coragem das Mulheres (243b):

Não é, decerto, possivel apreender melhor a similaridade e a diferença (...) de um outro modo que não seja através do confronto de vidas com vidas, feitos com feitos (...). De facto, as virtudes adquirem certas diferenças, graças à sua natureza, como se se tratasse de um cromatismo próprio, e assumem semelhanças por via dos costumes em que se radicam, do temperamento das pessoas, da sua criação e modo de vida. Por exemplo, Aquiles era corajoso de um modo diferente de Ajax².

Apesar de esta observação se aplicar ao confronto entre virtudes masculinas efemininas, também se adequa ao caso das Vidas Paralelas, pois as qualidades revelam-se na comunidade, na relação com o semelhante e numa circunstância concreta. Assim, a acção deve ser avaliada neste enquadramento, considerando as variáveis que lhe são relativas. No epílogo das Vidas, que corresponde à comparação (synkrisis) dos dois heróis, o biógrafo evidencia as virtudes e defeitos de ambos e observa

${ }^{2}$ Tradução de Fialho, Dias, Silva (2001: 15). 
Por um lado, Péricles governou um povo que se encontrava na maior prosperidade, muito grande por si mesmo e no cume do poder, pelo que podia parecer que se manteve até ao final seguro e intacto devido ao bem-estar comum e à força do Estado. As acçóes de Fábio, por outro lado, que recebeu a cidade nas circunstâncias de maior infortúnio e mais lamentáveis, não puderam garantir a segurança, mas soube erguer a cidade a partir da desgraça e melhorar a sua situaçâo (Fab. 28.1).

Assim, do ponto de vista militar, enquanto Péricles ergueu nove troféus dedicando-se, depois, mais a festas e reunióes públicas solenes do que a fazer guerra, Fábio, por sua vez, ergueu apenas dois, mas revelou-se homem de firme decisão tendo em conta os flagelos que então se abateram sobre os Romanos.

Além do facto histórico, também a própria estrutura narrativa de cada vida é diferente. Na Vida de Péricles, o biógrafo apresenta o percurso completo desde a infância até à morte, dedicando muita atenção à primeira fase (3-8), onde relata as origens da personagem, a caracterização física e psicológica e a formação e iniciação na vida pública; num segundo momento (9-37), a ascensão, apogeu e decadência no poder e finalmente, na terceira e última parte (38-39), são descritas as circunstâncias da morte, as exéquias e o impacto do desaparecimento do protagonista na comunidade. Na biografia do general romano, num capítulo apenas, são apresentados os dados relativos à filiação, infância e juventude. No capítulo segundo, a narrativa começa quando Fábio tinha já uma idade 
avançada, em 217 a.C., por altura do desastre da batalha do Trasimeno, deixando em branco mais de metade desta vida. Depois desta derrota, nesse mesmo ano é eleito dictator - altura em que a Vida atinge o ponto mais épico -, seguindo-se um relato sumário dos anos seguintes. Três anos depois, Fábio Máximo recupera Tarento (214 a.C.) e, nesse ano, terminaram os seus sucessos militares. Na recta final da biografia, tem lugar a ascensão de Cipião que expulsará definitivamente os Cartagineses de Itália, pondo termo à Segunda Guerra Púnica (218-201 a.C.). Assim, enquanto o primeiro conquista o estado de maturidade moral no final da vida, nos primeiros anos da Guerra do Peloponeso, Fábio conhece-o logo no início da Vida (2), tendo em conta a sua idade.

$\mathrm{O}$ que justifica, afinal, a comparação entre os dois estadistas? ${ }^{3}$ Em primeiro lugar, vários traços de carácter os aproximam: o domínio invulgar da oratória, isenta de ornamento $(5.1 ; 1.8)$; a forma de caminhar, tranquila $(5.1 ; 17.7)$; o não serem supersticiosos, não se

${ }^{3}$ Pietro Vannucci ou Perugino (1446-1524), conhecido pintor da Renascença italiana, é autor de dois frescos (1496-1507) da Sala de Audiência do Colégio de Cambio (Perugia) onde aparecem estas duas figuras. No primeiro é representado Fábio Máximo ao lado de Sócrates e Numa Pompílio, pairando sobre eles a virtude Prudência, enquanto que, no segundo painel, Péricles surge entre Cipiáo e Cincinato e sobre este grupo aparece a virtude Fortaleza. Com efeito, dificilmente um historiador ou um artista encontraria paralelos entre estas duas vidas, pelo que este paralelo não terá firmado uma tradição. Enquanto que um é modelo de fortaleza moral e política, o outro é o primeiro na prudência. Cf. CRespo ( ${ }^{4} 2007$ : 313), GuERrini (1991b: 305 sqq). 
deixando, por isso, surpreender por fenómenos irracionais (6.1; 2.3); o facto de, durante a invasão inimiga, as propriedades de ambos terem sido poupadas enquanto as restantes foram destruídas $(33.3 ; 7.4)$.

Do ponto de vista político, destacamos a ênfase na autoridade de um só homem que, no caso de Péricles durou quase toda a vida, originando a comparação com o tirano Pisístrato ${ }^{4}$, tanto pela voz como pela agilidade no discurso (7.1) - estas semelhanças valeram-lhe comentários jocosos por parte dos cómicos (16.1). Já a ditadura ${ }^{5}$ do general

${ }^{4}$ Em 560 a. C., Pisístrato (600-527 a. C.), toma o poder pela força e conserva-o quase ininterruptamente até ao fim da sua vida. O seu governo, bem como o dos filhos constituiu um período de grande florescimento em Atenas, pois foi nesta altura que se construíram várias obras públicas que prestigiaram a cidade: o templo de Atena, na Acrópole, o altar dos Doze Deuses na ágora, o santuário de Zeus Eleutério, no sudeste da cidade e a Fonte das Nove Bocas, que garantia o abastecimento de água. Durante a tirania dos Pisístratos, a cerâmica ática atingiu o seu apogeu e fomentou-se o culto de Atena e Dioniso através da importância dada às Panateneias e do aparecimento dos concursos trágicos, respectivamente. Após a morte de Pisístrato, o comportamento dos seus filhos tornou-se excessivo, pelo que gerou o descontentamento dos Atenienses e a tirania acabou por ser abolida pelos Alcmeónidas.

${ }^{5}$ Magistratura romana à qual se recorria em situaçóes de crise militar e política, atribuída por um magistrado com imperium (cônsul, pretor ou interrex) previamente autorizado pelo Senado, tratando-se, por isso, de uma nomeação e não de uma eleição. Além deste, também se podia recorrer ao voto popular, mas era invulgar. Esta magistratura terminava ao fim de seis meses (Cícero, As Leis 3.9; Tito Lívio 3.29.7) e, durante este período, o ditador detinha o poder absoluto, tendo a seu cargo o comando unificado do exército em caso de guerra (dictatura rei gerendae), o dever de refrear revoltas (dictatura seditionis sedandae) e de garantir a realização de eleiçóes, na ausência de cônsules (Fab. 9.4), não podendo alterar a constituição vigente. Após a sua eleição, o dictator ou magister populi ("mestre do exército dos cidadãos") deveria também ele próprio 
romano terminou ao fim de seis meses, mas continuou, na qualidade de cônsul (214 e 209 a.C.), a determinar os destinos do povo romano, controlando directamente decisóes do Senado (17.7), seja quando procurou evitar a derrota de Canas, dissuadindo Paulo Emílio da investida (14.4), seja quando tentou travar a ascensão de Cipião, querendo convencer Licínio Crasso da incompetência daquele (25.3). Além disso, os cargos que lhe foram atribuídos entretanto princeps senatus (209 e 204 a.C.), o de áugure (desde 265 a.C.) e pontifex maximus (216 a.C.) - permitiram-lhe

nomear um subordinado, o magister equitum, o chefe de cavalaria. Contudo, como se tratava de uma nomeação para resolver uma questão objectiva, estas magistraturas duravam o menor tempo possível, havendo mesmo relatos de dictatores que abdicaram antes que completar os seis meses (Tito Lívio 3.29.7; 9.34.12; 23.22.11 e 23.3). Os anais da história da República Romana atestam o recurso frequente a esta magistratura até ao final do século III a.C., não sendo conhecido nenhum exemplo ao longo do século II a.C. Reapareceu de forma ostensiva em 81 a.C., com Sula, que sendo nomeado dictator rei publicae constituendae causae, torna-se ditador vitalício até 79 a.C., data da sua morte (Apiano, Guerras Civis 1.3.10) - tendo abdicado, contudo, pouco antes de morrer. Mais tarde, Júlio César, depois de cinco consulados (59, 48, 46, 45, 44 a.C.) e de três magistraturas na qualidade dictator (49, 48, 44 a.C.), converte esta última em perpétua (Apiano, Guerras Civis 1.98.459). É assassinado a 15 de Março desse mesmo ano. Sobre esta magistratura na República Romana, vide o estudo LintotT (2003: 109-13). O conceito de ditadura romana é, com efeito, diverso daquele que se vulgarizou entre nós desde o início do século XX, com o estabelecimento de Estados autoritários e totalitários. Em 1921, o constitucionalista alemão Carl Schmitt (1888-1985) estabeleceu a distinção entre "ditadura de comissário", que parte da concepção de magistratura romana exposta em Tito Lívio - e a "ditadura soberana" que legitima, do ponto de vista jurídico e com fundamento teológico, a ordem "nova" ditatorial que é dotada de uma constituição própria (La Dictature, Paris, 2000, pp. 23-56, 135-54). 
construir uma auctoritas invulgar. No âmbito militar, há também um traço que aproxima estes dois políticos: a táctica defensiva face à invasão espartana e cartaginesa, respectivamente. Péricles optou por não envolver a cidade num combate contra sessenta mil hoplitas do Peloponeso e da Beócia, apesar da indignação do povo (33.5), mas não evitou a Guerra do Peloponeso por não ter revogado o decreto de Mégara (29.1). Fábio, por sua vez, resistiu à invasão cartaginesa, sem atacar, enquanto o inimigo esgotava, pouco a pouco, os seus recursos (5.3). No caso deste último, a estratégia manchou o seu estado de graça político, pois a população não via com bons olhos o avanço do inimigo e a destruição das propriedades dos agricultores face à aparente passividade do ditador. $\mathrm{O}$ traço anti-populista constitui também uma das características de Péricles (7.3) que deixava transparecer pelo aspecto fisionómico, ostentando um rosto austero, um discurso de mau tom, embora ágil (5.1), que se assemelhava ao de Pisístrato; a arrogância (39.2) que foi comentada pelo poeta Íon (5.3), ao ponto de a morte dos seus filhos legítimos, familiares e amigos ser vista como um castigo (37.5); o carácter aristocrático da sua democracia (9.1). O seu par romano, por sua vez, partilhava também deste mesmo traço (10.3), a julgar pelas ostentaçóes de poder durante a ditadura (4.2-3) e pelas observaçóes do biógrafo $(10.3)^{6}$.

${ }^{6}$ A propósito das referências ao povo nas Vidas Paralelas, vide o interessante estudo de SAÏD (2004:10) que reflecte sobre a forma como Plutarco se refere à psicologia da multidão: "the masses are more often than not characterized in a very negative way. As opposed to the members

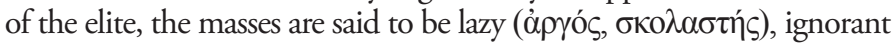

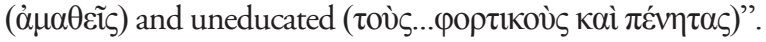


Esta resistência ao populismo não ofuscava, contudo, o pragmatismo político destes dois estadistas, que, em certos momentos, tiraram partido da irreflexão do povo. Péricles, querendo conquistar um poder sólido, aliou-se ao povo (11.1) e tomou as suas rédeas, levando a cabo medidas políticas a seu favor "imaginando constantemente na cidade um espectáculo para todos ou um banquete ou uma procissão, e procurando divertila com prazeres não estranhos às musas" (11.4). Assim, não só distraía a multidão que, ociosa, "se intrometia nas reformas políticas", mas gerava também, junto aos aliados, o medo da revolta (11.6) ${ }^{7}$.

Do mesmo modo, Fábio procura influenciar a população por meio de movimentaçóes de aparência. Em 217 a.C., a sua reforma como dictator começa por recuperar o sentido religioso no povo. Com efeito, era forçoso tornar propícios os deuses, já que Fábio a todos informou que a derrota se devera ao desprezo dos generais pelos deuses (4.4). Contudo, quando estes se manifestaram, pouco antes, sob a forma de sinais, o próprio Fábio tratou de os ignorar (2.3). Mais tarde, propôs também ao Senado que se eliminasse os lamentos femininos, proibindo ajuntamentos públicos para manifestar as desgraças em comum (17.7), mas que se evidenciasse a grandeza do desastre de Canas com a fraca concorrência às celebraçóes da deusa Ceres (18.2). Ambos partilhavam também do sentido de grandeza (megaloprepeia) a liberalidade com investiam

${ }^{7}$ Vide ainda Per. 7.3-5. 
dinheiro em eventos e obras públicas, algo elogiado por Aristóteles na Ética a Nicómaco (1122b7-9) ${ }^{8}$. Péricles, contudo, manifestou esta característica de forma mais expressiva (14.1) tendo em conta o seu volume de investimento em obras públicas (13-14;30.7); Fábio, por sua vez, querendo recuperar a confiança da população, promoveu espectáculos musicais e cénicos depois do desastre do Trasimeno (4.6) e, na celebração da tomada de Tarento (22.8), erigiu uma estátua equestre em bronze de si mesmo, visto como algo "muito extravagante" (atopoteros).

Além destas semelhanças evidenciadas pelo biógrafo, há que destacar aquela que é mais importante, pois nela consiste o programa moral deste par de Vidas, Plutarco refere-a no proémio9 da Vida de Péricles (2.5):

Eram estes homens semelhantes em diversas qualidades, principalmente na doçura (praotes), no sentido de justiça (dikaiosyne) e na capacidade de controlar a imponderação (agnomosyne) dos cidadãos e dos seus colegas, tornando-se muito úteis às suas pátrias.

${ }^{8} \mathrm{Na}$ Ética a Nicómano, Aristóteles elogia também este traço: “O magnificente gastará com coisas deste género com nobreza de carácter. Com efeito, a magnificência é um traço comum a todas as excelências. Além do mais, fá-lo com prazer e profusamente, pois o contar tostão por tostão é mesquinhez." Tradução de CAEIro ('2009: 99).

${ }^{9}$ Os proémios, à semelhança das synkriseis, eram exercícios de retórica. De acordo com essa tradição tinham como objectivo cativar o auditório e criar empatia entre este e o orador, despertando naquele o desejo de aprender com o discurso apresentado. De modo a cumprir esse propósito, Plutarco combinava a sua mensagem com recursos de retórica como as chreiai, as gnomai, comparaçóes e digressóes, de que este proémio é exemplo. 
Com efeito, tal é mesmo confirmado do ponto de vista quantitativo, pois este é o par de Vidas onde o termo praotes $^{10}$ bem como os seus correlatos surgem mais do que em qualquer outra obra, mais precisamente, dezasseis vezes ${ }^{11}$. A qualidade da praotes consta em ambas as caracterizaçóes directas destas figuras $(5.1,1.5)$ e no caso de Fábio, surge, pela primeira vez, quando era ainda uma criança. Em ambos os estadistas é apresentada como uma tendência da natureza (physis), mas os seus efeitos ampliam-se na esfera pública, convertendo-se, por isso, num valor político que marcará a conduta de ambos. A tradução mais próxima é "doçura" ou "moderação" e aparece conceptualizada na Etica a Nicómaco como a disposição intermédia entre os extremos, o irascível e a incapacidade de se irar, o seu oposto, por defeito (1108a 6, 1125b 26). Com efeito, o "doce" ou "moderado" de carácter (praos) permanece imperturbável e é arrastado pela emoção (1126a 1). Este valor surge muitas vezes em oposição à crueldade, violência ou tirania, expressóes de excessos, do extremo irascível.

A propósito deste valor, conclui Aristóteles na mesma obra:

Difícil de distinguir é também até que ponto alguém se irrita correctamente e para lá do qual está a errar. (...)

${ }^{10}$ Sobre a definição deste termo e seu sentido ético, vide o conhecido estudo de De Romilly (1979).

${ }^{11}$ STADTER (1975: 82 n.18). Sobre o conceito de praotes nas Vidas de Plutarco, vide o texto de Martin Jr. (1960). Este valor de "doçura" pode ser expresso em grego pelo termo praotes, por epieikeia, "indulgência" ou por philanthropia, "humanidade". Ribeiro Ferreira (2008b) 112; idem (2008a). 
Uma tal avaliação só pode ser feita pela percepção que se tem das circunstâncias particulares que de cada vez se constituem $^{12}$. (1126a 34, 1126b 4)

Estas "circunstâncias particulares” proporcionamse, com efeito, diversas vezes ao longo das duas Vidas. Esta tendência da physis manifesta-se em Péricles na maneira de andar (5.1), no facto de não ter prejudicado Címon (10.6), no trato humano (5.2) e em diversas decisôes políticas $(30.3 ; 32.3 ; 39.1)$. No caso do par romano, tal virtude é conhecida em Fábio desde a infância, na forma de caminhar (17.7) no convívio (1.5; 17.7), em campanha militar $(7.8 ; 20)$, na cena política (18.4) e ainda na morte dos filhos que suporta com tranquilidade (24.6), tal como Péricles (36.8).

A verdade é que ambos suportaram, com paciência e em silêncio, as maledicências da população (Per. 5.2, 33.6-7; Fab. 5.3 , 7.7, 10.2-3), dos seus pares (Per. 34.1; Fab. 5.5; 7.5), dos cómicos, no caso de Péricles (33.7); aconselharam prudência aos colegas (Per. 18.2; Fab. 2.4, 10.7, 14.4, 25.3) e, neste ponto, destacamos a célebre façanha de Fábio, quando enfrenta o exército de Aníbal para salvar Minúcio Rufo, o mesmo que, pouco antes, o tinha humilhado publicamente $(12.5 ; 29.2)$.

$\mathrm{O}$ facto de permanecerem firmes nas suas resoluçóes converte-os em valores seguros e credíveis para a população. Com efeito, enquanto Péricles é

12 Tradução de Caeiro (32009: 109-10). 
comparado a um médico - símile recorrente em Platão $^{13}$-, que cura as doenças da alma, acalma e encoraja o povo (Per. 37.1); o par romano é, por sua vez, comparado a um "templo" e a um "altar", junto do qual a multidão se refugia em tempo de crise.

Em suma, Plutarco apresenta-nos uma diversidade de "circunstâncias", perante as quais o ouvinte destas Vidas pôde fazer justa avaliação e "distinguir" os limites de cada acção, "de forma a servir de exemplo [apodeixis] aos filósofos" (Fab. 10.2).

Com efeito, como consta no proémio destas Vidas (Per. 1.2), é intrínseco ao espírito o desejo de aprender e observar, pelo que se deve buscar o melhor para contemplar, ou seja, a prática do bem ${ }^{14}$. A contemplação do homem-modelo em acção conduz necessariamente à imitação, e à prática de actos virtuosos de forma a conquistar as mesmas benesses da fortuna. Com efeito, o Bem (kalon) cria um estímulo activo $^{15}$ para aquele que contempla a sua expressão, a acção nobre, que serve de exemplum, neste caso,

${ }^{13}$ Górgias 456b, Fedro 270b-d, República 425a-426b.

${ }^{14}$ Observação semelhante é proferida por T. Carlyle (17951881), historiador e filósofo escocês, na conferência On Heroes, da qual extraímos um excerto: "Não podemos olhar para um homem superior, ainda que o consideremos imperfeitamente, sem ganhar algum benefício com tal contemplação. Um homem superior é sempre fonte de viva luz, junto da qual é aprazível estar. Luz que ainda nos ilumina (...) fonte de cuja radiação todas as almas se iluminam e aquecem pelo que junto dela se sentem bem." Traduzido por Ribeiro (2002: 15-6).

${ }^{15}$ Cf. Platáo, O Banquete 208-212 e Fedro 250 sqq. 
ao seu público, a elite aristocrática grega e romana. Como concluiu Plutarco no proémio destas Vidas, é que é possivel, a partir deste relato, avaliar se apontamos na direç̧âo correcta (2.5). 


\section{Fragmentos: Ediçóes e Respectivas Siglas}

ANACREONTE

Page: D. L. Page (i 962), Poetae melici Graeci, Oxford.

Antístenes

Dittmar: H. Dittmar (i9i 2), Aeschines von Sphettos, Berlin.

ANTÍsTENES Socrático

Walz: C. Walz (i 835), Rhetores Graeci, vol. II, Stuttgart.

Aristóteles

Rose: V. Rose (i 886), ARISTOTELIS QUI FEREBANTUR LIBRORUM

FRAGMENTA, LEIPZIG.

Arquíloco

Diehl: E. Diehl ( ${ }^{3}$ I 964), ANTHOLOGIA LYRICA GRAECA, Lipsiae.

CATÃo

Peter: H. Peter ( ${ }^{2}$ i 9i 4), Historicorum Romanorum Reliquiae (vol. I), LiPSIAE.

Comediógrafos gregos

K-A: R. Kassel e C. Austin (i983-i995), Poetae Comici Graeci, BERLIN.

EURÍPIDES

NAUCK ${ }^{2}$ : A. NAUCK ( ${ }^{2}$ I 889), TRAGicorum GRAECORUM Fragmenta, LEIPZIG.

\section{Heraclides PôNTICo}

Wehrli: F. Wehrli (i969), Die SChule des ARIStoteles, TeXte UND Kommentar, vol. III HeraKLEIDES PONTIKOS, BASEl.

\section{LOGÓGRAFOS E HISTORIADORES}

FGRHist: F. JACOBy (I96I-I968), DIE FRAGMENTE DER GRIECHISCHEN HISTORIKER, LEIDEN.

\section{Teofrasto de Éreso}

Fortenbaugh: W. W. Fortenbaugh et alit (1992), Theophrastus of EREsus (SOURCES For his LifE, WRITINGS, THOUGHY \& INFLUENCE), LEIDEN/New YoRK/KöLN. 
VIDA DE PÉRICLES 
(Página deixada propositadamente em branco) 


\section{INTRODUÇÃO}

Ao escrever as Vidas Paralelas, Plutarco tinha um objectivo pedagógico muito concreto que, como não poderia deixar de ser, influenciou o método em que se baseia para caracterizar os seus protagonistas: apresentar o homem-modelo em acção, pois é essa a melhor forma de se avaliar o seu carácter - virtudes e vícios. Só deste modo sentiremos a necessidade de imitar as suas qualidades e de evitar os mesmos erros e defeitos (Emílio Paulo 1, Demétrio 1. 1-6).

Assim, logo no proémio da Vida de Péricles (Per. 2. 5), Plutarco esboça o perfil do estadista, salientando as características que este possui em comum com o seu par - Fábio Máximo - moderação, justiça e autocontrolo - e que váo ser das mais exploradas e enfatizadas ao longo da biografia:

Pensámos, por isso, persistir na descrição das vidas e compusemos este décimo livro, que engloba a vida de Péricles e a de Fábio Máximo, que desenvolveu uma longa luta contra Anibal. Eram estes homens semelhantes em diversas qualidades, principalmente na moderação, no sentido de justiça e na capacidade de controlar a imponderação dos seus concidadãos e dos colegas, tornando-se muito úteis às suas pátrias. 
Seguindo um esquema tradicional, após o proémio (Per. 3. 1-3), Plutarco começa por identificar a "genealogia" de Péricles: era membro da tribo de Acamante $^{1}$ e do burgo de Colarges ${ }^{2}$, teve por pai $\mathrm{Xantipo}^{3}$, vencedor dos generais persas em Mícale, e sua mãe - Agariste - era neta de Clístenes ${ }^{4}$ (Per. 3. 1-3).

Ao nascimento de tấo ilustre figura, precede-o o sonho de Agariste (Per. 3. 3-4), que assemelha Péricles a um leão 5 . O elemento onírico tem origem mitológica e é tradicional na literatura grega (especialmente nos relatos historiográficos e biográficos), quando se trata de prever o nascimento de um herói, do fundador de uma dinastia ou de um monarca poderoso. Podemos salientar, dentre muitos, o sonho que anuncia o nascimento de Ciro (Heródoto 1. 107-108) e o oráculo que desaconselha o nascimento de Édipo (Sófocles, Rei Édipo 1175 sq.).

${ }^{1}$ Acamante é o epónimo desta tribo. Era filho de Teseu e Fedra e, embora não figure na epopeia homérica, lendas posteriores referem o papel importante que teve, com o seu irmáo Demofonte, na tomada de Tróia. Para conhecer melhor Acamante, consulte-se Grimal (1992: s. v.).

${ }^{2} \mathrm{O}$ demo de Colarges estava situado no extremo norte da Ática, próximo da encosta nordeste do monte Egáleo.

${ }^{3}$ Filho de Árifron, tornou-se membro da família dos Alcmeónidas pelo casamento com Agariste pouco depois de 500 a.C.

${ }^{4}$ Clístenes era um dos Alcmeónidas, aos quais se atribui a expulsão do tirano Hípias em 510 a.C., e foi responsável por importantes reformas que ditarão a criação da democracia.

Talvez o breve elogio de Clístenes, enquanto opositor da tirania e impulsionador da democracia, pretenda sugerir uma certa hereditariedade na dedicação à causa do povo, como meio de esbater as acusaçóes de exercício de poder monocrático feitas contra Péricles.

${ }^{5}$ Cf. Heródoto 6. 131. 
Dadas estas informaçôes, o nosso biógrafo passa ao nascimento da criança. É um momento importante da narrativa, pois embora se saliente que o aspecto geral do novo ser era perfeito e sem censura ${ }^{6}$, também se apresenta uma característica física que o vai acompanhar pela vida fora: a deformidade da cabeça, que viria a ser referida vezes sem conta pelos cómicos ${ }^{7}$, mas que segundo Plutarco, os escultores procuravam disfarçar, já que o representavam sempre com um elmo. Essa marca de nascença e o sonho que Agariste tem podem ser vistos como indiciadores dos principais traços da personalidade de Péricles ${ }^{8}$ : quanto à cabeça - demasiado grande - equivale talvez à parte do corpo onde, por excelência, residem uma inteligência e uma perspicácia inusitadas; o sonho, que identifica Péricles com o rei das selvas, pode ser interpretado como presságio da liderança que o recém-nascido viria a exercer em Atenas na idade adulta, bem como da sua coragem e capacidade de chefia.

É, porém, óbvio que o homem é resultado não só da sua própria natureza, mas também fruto da sua vivência

${ }^{6}$ Este tipo de avaliação é muito helénica, pois segue o conhecido critério do kalos kagathos, segundo o qual importava que tudo e todos fossem belos - em termos físicos - e bons - em termos morais.

7 Cf. Per. 3. 4, 3. 6, 13. 9. É importante, porém, notar que a insistência dos cómicos na deselegância física de Péricles acaba por ser uma forma caricaturada de reconhecer a sua inteligência superior.

${ }^{8}$ Aliás, a análise das qualidades do protagonista, levada a cabo na primeira parte de cada Vida, relaciona-se muitas vezes com a sua vocação pública, isto é, muitos deles apresentam uma forte predisposição para um determinado estilo de actuação política. 
em sociedade e, consequentemente, da aprendizagem que nela faz. Por isso mesmo, a etapa seguinte da caracterizaçáo de Péricles passa pela referência à sua formação cultural e respectivos mestres.

Importa, antes de avançarmos, reflectir um pouco sobre o ensino nos inícios do século V a.C. Nesta altura, vigorava a educação que Aristófanes (Nuvens 961 sq.) chamava de antiga - archaia paideia - e que consistia essencialmente na aprendizagem das letras (com base nos poetas do passado) e dos números, cujo ensino era ministrado pelo gramatistes, na da música (pelo kitaristes) e na exercitação física (pelo paidotribes). Kagan (1990: 20-21) faz-nos uma caracterização bastante clara da educação na Atenas desse tempo:

The traditional education of Athenian youth was practical and ethical rather than intellectual. Physical training prepared the boys for the athletic contests that were a regular part of religious festivals in Athens and of Pan-Hellenic competitions. (...) Musical education taught them to sing and play the lyre and an oboelike instrument called the aulos, but most of all to learn the traditional body of poetry, chiefly the epics of Homer.

Segundo Marrou (1948: 81), o próprio Péricles teria recebido esse tipo de educação:

Ainsi les Athéniens nés dans les années 490 (ils se sont appellés Périclès, Sophocle, Phidias...), qui, dans tous les domaines: la politique, les lettres, les arts, portèrent la culture classique à un si haut degré de maturité, n'avaient 
encore reçu que cette éducation très élémentaire qui, au point de vue de l'instruction, ne sélevait guère plus haut que notre enseignement primaire actuel.

Segundo no-lo relata Plutarco, Péricles teve como mestre na área da música Dámon (Per. 4. 1-4) ${ }^{9}$, um dos mais antigos e importantes cultores desta arte (muito admirado por Sócrates e Platão). Consta que procurava ocultar a sua simpatia pela tirania (mas terá acabado por ser vítima do ostracismo por causa desta sua tendência) - o que de imediato nos faz reflectir sobre os possíveis efeitos deste convívio sobre o governo do filho de Xantipo ${ }^{10}$, que é invocado por Tucídides como o "governo do primeiro dos cidadãos" (2. 65. 9) e comparado, pelos cómicos, a uma tirania (Per. 16. $\left.{ }^{11}\right)$. Veremos adiante que o próprio Péricles parecia temer a sua sorte por ser parecido com Pisístrato.

Mas, depois da formação básica, os jovens podiam (e deviam) aproximar-se de indivíduos que lhes pudessem ensinar outros assuntos mais elevados. Assim, dois outros

${ }^{9} \mathrm{O}$ biógrafo apresenta igualmente outra versão, que atribui a Aristóteles (fr. 401 Rose): de acordo com o Estagirita, o professor seria Pitoclides de Ceos, do qual apenas se sabe que foi pitagórico e músico. No entanto, esta informação baseia-se em Platão (Protágoras 316e, escólio a Alcibiades 118c) e não em Aristóteles, o que pode significar ou que Plutarco confundiu as fontes, ou que esta referência faz parte de uma das muitas obras perdidas.

${ }^{10}$ Plutarco (Per. 4. 4) cita, inclusive, um passo de Platão Cómico (fr. 207 K.-A.) que sugere essa influência.

${ }^{11}$ Para os cómicos, a supremacia de Péricles - que era quem na realidade governava sob a aparência de respeitar a vontade da turba - é prejudicial para a democracia. Já Tucídides parece vê-la como um bem, pois, como considera o povo inconstante, se não fosse $o$ pulso forte de Péricles, o caos seria total. 
nomes se destacam enquanto seus mestres, ambos filósofos ${ }^{12}$ : Zenão de Eleia (Per. 4. 4) ${ }^{13}$ e Anaxágoras de Clazómenas ${ }^{14}$ (Per. 4. 5 - 6. 5). Ao primeiro, parece que poderemos atribuir algum contributo para $\mathrm{o}$ desenvolvimento da capacidade oratória de Péricles. Quando a ele se refere, Plutarco diz que o seu método era discutir com toda a gente, empregar os argumentos mais subtis e levar os adversários a não saberem que responder-lhe (Per. 4. 5). Deste passo, facilmente nos recordamos num dos capítulos seguintes (Per. 8. 5):

Quando, certa vez, Arquidamo, rei de Esparta, the perguntou se era ele ou Péricles quem combatia melhor, [Tucídides, o filho de Melésias ${ }^{15}$ ] disse: "Quando eu o derrubo em combate, ele nega ter caido e leva a melhor, pois altera a opinião de quem assiste."

Esta resposta, de facto, náo poderia caracterizar melhor a eloquência do filho de Xantipo, cuja

${ }^{12}$ Um bom e verdadeiro político deve, na visão platónica, fazer acima de tudo um estudo rigorosíssimo sobre a virtude (i.e. o Bem) - logo, deve dedicar-se à filosofia -, pois o seu objectivo é fazer dos seus concidadãos pessoas melhores, que respeitem a lei.

13 Apenas Plutarco apresenta Péricles como discípulo de Zenão (ca. 490 - 445 a.C.). Vide Guthrie (1969: 80 sq.).

${ }^{14}$ Anaxágoras de Clazómenas viveu no séc. V a.C. e terá chegado a Atenas em 480. Destacou-se pelo seu interesse pelas ciências naturais, nomeadamente pela origem do cosmos e ainda pela negação da religião politeísta e antropomórfica que então vigorava. Foi ele quem introduziu o conceito de noos como força que rege o cosmos. Vide Guthrie (1969: 266 sq.).

${ }^{15}$ Note-se que o Tucídides aqui em causa é o opositor político de Péricles e não o famoso historiador. 
extraordinária capacidade permitia adaptar os próprios acontecimentos aos seus interesses. Era assim a excelência oratória que os sofistas tanto defendiam e que Platão tâo acerrimamente criticava: ser capaz de defender ou criticar o mesmo ponto de vista, de acordo com as conveniências do momento.

Mas será a Anaxágoras que Péricles mais terá ficado a dever - pelo menos segundo Plutarco (e mesmo Platão $\left.{ }^{16}\right)$ - em termos de formação pessoal. Dele "herda" e com ele aperfeiçoa a maioria - se não a totalidade das suas qualidades, desde a elevação e nobreza de sentimentos, à grandeza da alma (phronema), à majestade (onkos) e à dignidade de conduta (axioma).

E essas qualidades morais que Péricles desenvolveu com Anaxágoras manifestam-se exteriormente no discurso do estadista e na sua própria postura. $\mathrm{Na}$ verdade, um bom orador deveria possuir qualidades a vários níveis: internas - como a inteligência e o carácter - e externas, como a pose, a teatralidade e o tom de voz. Possuí-las na justa medida é atingir a perfeição, da qual Péricles é paradigma (Per. 5. 1).

Este é o último capítulo da primeira parte do relato biográfico dedicada à fase anterior ao ingresso na vida pública activa. Nele, como bem podemos depreender pela transcrição feita, o biógrafo salienta algumas características do discurso de Péricles e descreve também a moderação que se manifesta em toda a sua maneira de ser. Quanto à eloquência, convém salientar

${ }^{16}$ Respectivamente Per. 4.6 e Fedro 270a. 
que será um ponto novamente abordado alguns capítulos mais adiante. De facto, uma das principais marcas do estilo biográfico de Plutarco é a redefinição constante e progressiva dos traços de carácter das suas personagens. É assim que ele individualiza, que torna mais singulares, as características que pretende realçar.

Sobre o discurso, diz-se que era "elevado e isento de vulgaridades populares e de mau tom" e que a sua voz era imperturbável. Daqui podemos inferir dois traços fundamentais da personalidade de Péricles - que serão mencionados e sugeridos várias vezes ao longo da biografia, ainda que em outros contextos: a sua moderação e o seu auto-domínio. Também a inflexibilidade do olhar, a tranquilidade do andar, a modéstia no vestir - no fundo, a dignidade do porte e mesmo da linguagem demonstram essas mesmas características e a seriedade do nosso estadista.

Com Anaxágoras, Péricles aprendeu ainda a não ser supersticioso ${ }^{17}$. Segundo Plutarco, isso aconteceu porque a posse de conhecimentos científicos o levou à melhor compreensão e conhecimento dos fenómenos naturais ${ }^{18}$, o que não permite aceitar qualquer justificação sobrenatural para os acontecimentos. Esta característica

${ }^{17}$ Em Per. 6. 1, salienta-se a importância da filosofia para a formação do indivíduo. Lembremo-nos de que, já Platão o dizia, foi o estudo da filosofia - condiçáo sine qua non para um bom desempenho político - que marcou a diferença entre Péricles e os outros políticos mais distintos do seu tempo.

18 Em Caracteres (cap. 16), Teofrasto descreve a figura do supersticioso e define superstição como sendo simplesmente o temor do sobrenatural. 
é exemplificada em Per. 35. 2, quando, no momento da partida para Epidauro, tem lugar um eclipse do sol, que quase paralisa todos de pavor. Verificando o medo do piloto, Péricles fá-lo compreender que nada há a temer, que se trata de um fenómeno inofensivo, tal como o é a escuridão provocada pelo cobrir do rosto com um manto. É assim que consegue fazer com que a armada parta.

No entanto, no final desta biografia, em Per. 38. 2, quando Plutarco nos informa da doença que viria a vitimar o estadista, invoca Teofrasto: ao que parece, Péricles estaria de tal modo debilitado que até aceitava recorrer a amuletos, comportamento tipicamente feminino e que demonstra superstição ${ }^{19}$. Segundo este peripatético, a situação apenas mostra que a dor, o sofrimento e a vivência de momentos difíceis fazem com que uma pessoa altere o seu comportamento. Mas, se de facto isto aconteceu, foi um dos raríssimos momentos em que a moderação de Péricles não conseguiu resistir aos infortúnios do destino por efeito do acumular de situaçóes penosas na fase final da sua vida (recordemos a perda dos filhos legítimos, de outros familiares e amigos em consequência da peste e, agora, o seu próprio contágio). Nota-se, pois, uma certa humanização de Péricles - que, de algum modo, vacila no seu habitual equilíbrio. O que importa é que ele se esforça por se manter inalterável mesmo nas situaçóes de maior adversidade.

${ }^{19}$ Sobre a debatida questão da alteração de carácter de Péricles e a posição de Plutarco sobre a matéria, leiam-se GILL (1983: 469481); SWAin (1989: 62-68); PÉREZ JimÉneZ (1994: 331-340). 
Mas a sobriedade de Péricles nem sempre era bem interpretada. É o que nos diz Plutarco com base em Íon ${ }^{20}$, que opõe à delicadeza e afabilidade de Címon o desprezo pelos outros, o orgulho e a arrogância de Péricles (Per. 5. 3).

Para desfazer essa visão negativa - com a qual Plutarco claramente náo concorda - recorre ao testemunho de Zenão, que explica que há quem confunda a majestade (semnotes) de Péricles com arrogância e orgulho e apresenta o "atacado" como modelo de conduta a seguir (Per. 5.3).

A partir do capítulo sétimo, entramos na segunda parte, dedicada à vida política e militar, onde finalmente encontramos o protagonista em acção. Plutarco começa por nos relatar a iniciação de Péricles na vida pública ${ }^{21}$

${ }^{20}$ FGrH 392 F 15. Íon, cuja vida decorreu entre cerca de 490 e 424 a.C., atacava Péricles provavelmente como consequência do tratamento que os Atenienses deram à sua cidade natal durante a Guerra de Samos (Per. 28. 7). Vide Lesky (1995: 439-441); Guthrie (1969: 158).

${ }^{21}$ Aquele que pretende ingressar na vida pública - quer prefira a carreira política quer a militar - deve possuir determinadas características inatas (physis), que podemos agrupar distintamente, embora devam sempre coexistir para que os indivíduos tenham bons desempenhos: por um lado, a philotimia ('desejo de honras'), a philodoxia ('desejo de glória') e a philonikia ('desejo de vitórias'), entre outras - que servem de incentivo à sua acção; por outro, a praotes ('doçura') e a philantropia ('humanidade').

As do primeiro grupo, se isoladas das do segundo, podem ter consequências nefastas, já que estão directamente relacionadas com a ambição de honras e poder; logo, quando não são bem "doseadas", levam a excessos. Se o homem público apenas possuir as do segundo grupo, pode não se sentir suficientemente motivado para a acção e náo intervir. 
com particular destaque para a actividade político-militar. Interessa-se pelos condicionalismos encontrados pelos estadistas quando ingressam na vida activa, por considerar que este é um dos momentos onde mais se evidenciam as suas características morais e políticas.

No caso de Péricles, de facto, de imediato se manifesta a sua prudência ${ }^{22}$. Plutarco apresenta-nos um jovem que teme o povo por possuir muitas semelhanças com Pisístrato, quer em termos fisionómicos, quer na voz e na agilidade do discurso ${ }^{23}$, com a agravante de pertencer à nobreza e de ter amigos poderosos e influentes. Como sabia que o regime tirânico era profundamente odiado pelos Atenienses, não podia correr o risco de fazer recair sobre si acusaçóes de simpatia por este tipo de opçáo política e de, eventualmente, ser condenado ao ostracismo. Como tal, prefere moderar e adiar a sua intervenção em termos políticos, mas náo se coibe de mostrar, no campo militar, toda a sua coragem ${ }^{24}$ e capacidades.

Só quando o contexto político muda - com a morte ou exílio de alguns dos seus opositores e com a constante ausência de Címon (em expediçōes militares) - é que ele altera a estratégia, por considerar ter chegado

22 Aristóteles (Ética a Nicómaco 1140b 4) define assim a prudência (phronesis): resta, pois, que esta é uma capacidade verdadeira e de acordo com a razáo para se agir segundo aquilo que é bom ou mau para o homem.

${ }^{23}$ Estes traços são aproveitados com alguma frequência pelos cómicos que o acusam de querer restaurar a tirania em Atenas (Per. 16. 1).

${ }^{24}$ Sobre esta virtude - andreia - vide Ética a Nicómaco 1115 a 6-1116a 10. 
o momento oportuno (Per. 7. 3). Então, alia-se ao povo (embora a sua natureza fosse pouco popular - Per. 7 . 4) para tentar esbater a suspeita de apreço pela tirania e para vencer o seu principal adversário, Címon.

A vontade de se dedicar à política faz com que renuncie à vida social, por entender que esse tipo de exposição náo se coaduna com a austeridade que deve caracterizar um verdadeiro político e que pode mesmo comprometer o respeito que o povo lhe tem (Per. 7 . 5). Isolando-se assim, pretendia conservar - no dizer de Plutarco (Per. 7. 6) - a admiração que se tem pela virtude daqueles cujos feitos são de renome, mas com os quais não privamos no dia-a-dia. Penso que este é um critério válido: todos sabemos que a familiaridade pode levar a situaçôes de extremo à-vontade onde há maior probabilidade de se cometer um deslize que macule a opiniâo que os outros fazem de alguém. E isso sobretudo no caso de figuras públicas - como os políticos. Ainda nos nossos dias há a preocupação de julgar as capacidades e os actos políticos com base na vida privada, inclusivamente de atribuir decisóes políticas importantes à necessidade de esbater os comentários sobre "pequenos" tropeços da vida familiar ${ }^{25}$. Assim, quanto menor o tempo de exposição no convívio com as massas - talvez também Péricles o pensasse -, menores seriam as possibilidades

25 Em Per. 31-32, Plutarco menciona uma acusação dessa natureza: havia quem alegasse que Péricles náo cedeu às exigências dos Lacedemónios para dispersar as atençóes das acusaçóes feitas contra Fídias, Aspásia e Anaxágoras e foi por isso que eclodiu a Guerra do Peloponeso. 
de ser apanhado em falso e de perder o respeito que por ele sentiam (o que é importante sobretudo em início de carreira) $)^{26}$.

Deste modo, Péricles póe ao serviço da democracia uma atitude fortemente aristocrática já que se nota uma certa aversáo pelo convívio popular. Mas, por outro lado, esta atitude em exagero tem os traços do arrogante que Teofrasto descreve no capítulo 24 de Caracteres.

Este medo salutar - mas quiçá um pouco exagerado - fez com que delegasse intervençóes relativas a assuntos menores na Assembleia a alguns dos seus correlegionários, intervindo apenas quando as questóes eram verdadeiramente importantes. Péricles, se vivesse nos nossos dias, daria um excelente consultor de imagem para os políticos, pois sabia geri-la muitíssimo bem, analisando correctamente os prós e os contras de uma exposição excessiva, e, mais importante, sabia escolher o momento oportuno para as suas intervençóes.

É no contexto da iniciação política que Plutarco vai aprofundar, tal como referimos atrás, a caracterização da eloquência de Péricles - o que é compreensível, já que esta foi talvez (em conjunto com a moderação e perspicácia) a principal arma utilizada para a sua ascensão. Segundo o biógrafo, não terá sido difícil atingir um nível elevado de perfeição - e já sabemos que até Platão lhe elogiava as capacidades oratórias - pois bastou-lhe conciliar as características inatas de orador - estilo e linguagem 1. 99 .

${ }^{26}$ Sobre a mesma prática nas monarquias orientais, cf. Heródoto 
com a elevação de sentimentos e com os ensinamentos filosóficos veiculados por Anaxágoras. Os próprios comediógrafos (Per. 8. 3) reconheciam a qualidade do seu discurso e com ele justificavam a alcunha por que era conhecido - Olímpico.

Mas a moderação - decerto uma das qualidades mais marcantes de Péricles - também se manifestava neste campo: chegava a invocar o auxílio divino para que nenhuma palavra menos própria lhe escapasse dos lábios (Per. 8. 6).

E os traços da personalidade de Péricles - sobretudo a perspicácia - continuam a extravasar facilmente das suas acçóes, nomeadamente da estratégia que elaborou para alcançar em definitivo o poder: bater o seu principal rival, colocando-se ao lado do povo. Para tal executa uma série de medidas favoráveis ao demos - como a instauração da mistoforia. Quando Címon morre, Péricles fica isolado no poder, mas os aristocratas - que não viam com bons olhos essa situação - escolhem-lhe um adversário: Tucídides, filho de Melésias. Mais uma vez, para fazer frente ao rival, ele tenta a todo o custo agradar à população, recorrendo para isso à organização constante de festas e solenidades (medida utilizada pelos políticos de todos os tempos). Incentiva ainda a formação de mercenários e a colonização como forma de se desfazer dos inactivos que poderiam querer prejudicar as suas reformas políticas, aproveitando para diminuir a miséria e conter possíveis revoltas dos aliados (Per. 11). O impulso às obras públicas é também uma medida ponderada para, além de embelezar a cidade, ocupar a população. 
Ora o que se verifica é que Péricles, quando buscava a solidez do poder, náo se coibe de fazer as vontades do povo. Nada de estranho - o mesmo se passa nos nossos dias com os políticos que, em campanha, a tudo dizem que sim. A diferença entre Péricles e os restantes políticos reside no comportamento "pós-eleitoral" 27 . É que, de um modo geral, quando um candidato ascende ao poder, esquece as promessas e age de modo a obter a sua satisfação pessoal, isto é, zela pelos seus interesses, colocando-os à frente do bem-estar geral. No caso de Péricles, ele também deixa de fazer as vontades à população ${ }^{28}$. No entanto, fá-lo porque, na maior parte dos casos, o povo é uma massa de opiniáo inconstante e precipitada, que

${ }^{27}$ O comportamento de Péricles é ainda mais louvável se tivermos presente o difícil equilíbrio entre demagogia e moderação. Este é, de facto, um dos aspectos mais controversos da política deste estadista. De Platão vieram as críticas, que o acusam de ter conduzido o povo a um comportamento progressivamente mais amoral. Plutarco, porém, parece louvar esta dicotomia de difícil controlo, na medida em que, sendo o povo instável, Péricles fazia bem em tentar manter-se no poder, pois ninguém melhor do que ele - com a sua moderação - poderia orientá-lo.

${ }^{28}$ Como um médico, que náo pode dar ao paciente apenas o remédio mais saboroso, mas que tem de saber receitar o que é mais apropriado para a doença manifestada (Per. 15. 1). Mas mais do que isso, tal como um médico, é necessário ser paciente para não dar importância às injúrias proferidas nos momentos de sofrimento (Per. 34. 5). Este tipo de comparaçáo com base na figura do médico foi talvez influenciado por Platão, onde é muito frequente (vide Górgias 456b). Importa ainda referir a comparaçấo com um piloto (Per. 33. 6) que tem que ignorar as lágrimas, as náuseas e o medo dos passageiros para poder agir de modo a que não naufraguem todos. 
se deixa levar pelos impulsos momentâneos. E não é possível seguir tais pareceres, sob pena de, no futuro, as consequências serem devastadoras. Há necessidade de se ser prudente ${ }^{29}$. Assim, Péricles póe os interesses da pólis à frente dos seus próprios e à frente dos "pseudo" interesses da população. Por vezes, chega mesmo a ser insultado e acusado de cobardia ${ }^{30}$, mas o seu bom-senso e o seu auto-domínio fazem-no suportar com calma e em silêncio as injúrias dos inimigos ${ }^{31}$ : é isso que acontece quando ele, perante a invasão lacedemónia, se recusa a combater no solo da Ática, optando por mostrar o valor dos Atenienses no mar (Per. 33. 6). E o povo, embora muitas vezes discordasse e até se manifestasse contra as suas decisóes, nunca deixava de o seguir e, normalmente, de acabar por concordar com as opçôes por ele tomadas.

Péricles só conseguiu vencer definitivamente Tucídides - que foi condenado ao ostracismo - após resolver a oposição que se fazia sentir por causa das

${ }^{29}$ Em Ética a Nicómaco 1140 b 7, Aristóteles revela uma opinião favorável acerca da prudência de Péricles

30 Segundo o Estagirita (Ética a Nicómaco 1116a 10), os homens corajosos são activos no momento de agir e calmos antes. Era precisamente isso que acontecia com Péricles. Ele sabia que há momentos oportunos para levar a cabo todas as acçôes. É então que devemos dar o nosso máximo; até lá, a serenidade é a melhor forma de reunir as energias necessárias.

${ }^{31} \mathrm{O}$ comportamento de Péricles coincide com o defendido por Aristóteles (Etica a Nicómaco 1100b 35): o homem verdadeiramente bom e sensato, pensamos, suporta decentemente todas as vicissitudes e executa sempre as acçóes mais nobres, como também um bom general faz o melhor uso possivel do exército sob o seu comando. 
despesas que as obras de embelezamento da cidade exigiam. A primeira crítica que lhe foi feita consistia no facto de o dinheiro ser oriundo das contribuiçóes das cidades aliadas da Simaquia de Delos - ao que respondeu que as cidades aliadas tinham a protecção por que pagavam (Per. 12.3-5); a segunda foi motivada pelas despesas que a oposição dizia excessivas - Péricles propôs-se assumir pessoalmente todas elas (Per. 14. 1-2). A eloquência, a perspicácia e o bom-senso de Péricles permitiram-lhe colocar o povo a seu favor.

A liberalidade com que investia dinheiro nas obras faz lembrar a caracterização da magnificência - megaloprepeia - que Aristóteles propóe na Ética a Nicómaco (embora Plutarco náo recorra a este termo nem faça uma caracterização directa relativamente a esta qualidade $)^{32}$.

Mas o filho de Xantipo nunca recorreu aos dinheiros públicos para aumentar a sua fortuna pessoal, enquanto zelava também com todo o rigor - pelo que era muito criticado pelos filhos - pelos bens herdados do pai (Per. 16. 4-5). A sua incorruptibilidade (adorotatos) e o desapego à riqueza (chrematon kreitton), aliados à famosa eloquência e à conduta, eram sem dúvida as bases da sua autoridade e do respeito que o povo por ele nutria. Era obviamente necessária uma grande organização para que o cuidado com os seus bens pessoais não interferisse com as responsabilidades públicas, as receitas, o exército, as frotas, as ilhas e o mar (Per. 16. 2).

${ }^{32}$ Ética a Nicómaco 1122b 6-10. 
Também no domínio militar a prudência, a sensatez de Péricles eram uma constante. Ele próprio enaltecia o facto de nunca ter posto, em vão, a vida dos seus concidadáos em perigo (Per. 18. 1) ${ }^{33}$. Aliás, quando Tólmides pretende recrutar muitos jovens para uma expedição, ele aconselha a que se espere algum tempo. E o certo é que pouco depois aquele pereceu no campo de batalha (Per. 18. 2-3). Os seus concidadãos ficaram admirados com tanta sensatez e com a amizade, com o cuidado que tinha por eles (philopolites).

Procurava refrear os desejos expansionistas e irreflectidos do povo (especialmente em relação ao Egipto, a Cartago e à Etrúria - Per. 21. 1); esforçava-se por agir com humanidade junto aos povos inimigos. Esta ideia fica clara em Per. 23. 4: apenas os Hestieus foram alvo de tratamento inflexível, pois tinham feito refém uma nau ática e matado toda a tripulação. $\mathrm{O}$ facto de só esses serem maltratados mostra que Péricles tinha um forte sentido de justiça e grande moderação - não se deixou tomar pela dor e pela ira de ver os concidadáos mortos para, como vingança, massacrar o maior número possível de inimigos ${ }^{34}$.

${ }^{33} \mathrm{Um}$ bom exemplo desta situação é o alegado suborno de Plistóanax, que fez com que o exército inimigo batesse em retirada, o que evidentemente evitou batalhas e mortes (Per. 22. 2-3). Neste episódio também se evidencia a clarividência de Péricles que previu - e muito bem - a cedência do inimigo.

${ }^{34}$ Este exemplo funciona como excelente argumento contra a acusação feita por Dúris de Samos (Per. 28. 2), que Plutarco nega, invocando a ausência de referência a esse acontecimento em Éforo, Tucídides e Aristóteles, para mostrar a parcialidade daquele autor. 
Também a estratégia para distrair os soldados que participaram no cerco de Samos ilustra bem a sua perspicácia e capacidade de levar o povo a fazer o que a longo prazo será mais benéfico. Com a instituição do dia branco, minora o descontentamento do exército que queria a todo o custo combater. Para tal, divide-o em oito partes: a que tirasse a fava branca faria um festim e descansaria, enquanto as outras iriam para a refrega (Per. 27. 2).

A forma como Péricles incentiva os seus aliados e como exibe o seu poderio aos bárbaros é também um bom exemplo de perspicácia e previsão político-militar: contentes, os aliados manter-se-ão ao seu lado; prudentes ou temerosos, os inimigos hesitaráo em atacar.

A prudência e grandeza de alma de Péricles foram também responsáveis pela não anulação do decreto de Mégara, o mesmo é dizer, pela Guerra do Peloponeso. Essas suas qualidades fizeram-no ver que essa seria a melhor opção, pois as exigências dos Lacedemónios que temiam o crescente poder ateniense - tinham por principal objectivo verificar se "os mais fortes" cediam (o que seria uma inegável prova de fraqueza e um precedente incontornável para exigências ainda maiores). Houve, porém, quem o acusasse de agir assim para demonstrar o poderio. No entanto, a descrição que Plutarco faz do decreto permite realçar indirectamente - e mais uma vez - a prudência e a moderação de Péricles, já que o biógrafo nos diz que o decreto possuía essas virtudes (Per. 30. 3). Outros motivos lhe testaram as mesmas qualidades: o caso da estátua criselefantina (Per. 31. 3) e as invasóes da Ática por Arquidamo (Per. 33. 5-6): é que ele conseguiu prever 
com a antecedência necessária o que poderia acontecer e assim desmentir suspeitas que colocariam em causa a sua honestidade e incorruptibilidade.

Mas Péricles não era só o homem público. Além da amizade que o unia a Fídias e a Anaxágoras (as mais realçadas por Plutarco), era também o companheiro carinhoso, que não entrava nem saía de casa sem beijar Aspásia, que amava com especial ternura (Per. 24. 9). Foi ela quem pela primeira vez o fez perder o controlo em público, quando, por altura do julgamento - segundo o relato de Ésquines (Per. 32. 5) -, ele, chorando em tribunal, implorou por ela aos juízes.

Na verdade, inicialmente, Péricles tinha sido casado com uma aristocrata, sem ter encontrado nesse matrimónio a convencional satisfação. Só o raciocínio de estadista que caracterizava Aspásia despertou nele uma verdadeira paixão. E mais uma vez temos a simbiose entre vida política e privada: é que, ao que parece, a "Nova Hera" tinha um papel de peso nas decisóes políticas que Péricles tomava. Basta recordar o tão apregoado Decreto de Mégara.

Mas, além de companheiro, era pai. Apesar dos muitos desentendimentos com os filhos por causa do rigor com que administrava os seus bens, quando estes morreram vitimados pela peste sofreu bastante. No entanto, conseguiu manter-se imperturbável, sereno, sem demonstrar a sua dor e sem derramar uma lágrima até à morte de Páralo, o seu último filho legítimo (Per. 36). Então não pôde conter as lágrimas e os gemidos, o que parece sugerir uma certa humanização da personagem, ou, se quisermos dizer com Teofrasto, uma alteração de carácter provocada pelo excesso de dor. 
Embora Plutarco lhe reconheça tantas virtudes, o certo é que, como tivemos oportunidade de ver, muitos dos seus concidadáos o criticaram largamente em vida. A tal ponto, que o sofrimento provocado pela morte dos filhos e de outros familiares e amigos foi visto pelos Atenienses como um castigo pela sua arrogância e orgulho (Per. 37. $5)^{35}$. Foi sobretudo após a sua morte, como aliás ainda nos nossos dias é prática corrente, que lhe deram o devido valor, ao verificarem que nenhum dos seus sucessores possuía a "sensibilidade viva e sábia de Péricles", que "era moderado na austeridade e grave na moderaçáo" (Per. 39. 3).

Demoremo-nos, agora, um pouco mais na análise breve do vocabulário específico que é utilizado. Além dos termos que foram sendo referidos, Plutarcoempregou vários sinónimos para determinadas características pessoais, nomeadamente para a moderação.

Mesmo numa primeira análise, depressa se reconhece a influência da escola peripatética ${ }^{36}$ através do recurso à sua terminologia (e às vezes pela reminiscência de conceitos que parecem estar presentes,

${ }^{35} \mathrm{Na}$ verdade, os últimos anos da vida de Péricles foram extremamente difíceis, já que, com o início da guerra contra Esparta seguido do deflagrar da peste, o controle do povo se tornou uma tarefa ainda mais árdua. Este chegou mesmo a afastar o estadista do comando da polis. Mas, com o que o povo não contava era com a inexistência de outro chefe de Estado tão capaz como o filho de Xantipo. Deste modo, a massa inconstante viu-se na necessidade de o reconduzir ao poder. Péricles viria a morrer pouco tempo depois.

36 Os Peripatéticos, que davam especial ênfase ao estudo da personalidade humana, determinaram muitíssimo o método biográfico grego, como se pode constatar pelo estudo atento das Vidas. 
embora não sejam designados). Mas também logo nos apercebemos de que Plutarco não está obcecado pela exactidão da terminologia e que não segue religiosamente as definiçóes de Aristóteles, adaptando-as à sua própria visão do mundo e da personalidade humana. É isso que acontece, parece-nos, com o uso de sophrosyne (Ética a Nicómaco 1118a-1119a). Esta palavra, em Aristóteles, é utilizada em relação à alimentação e a necessidades físicas. Não é esse o sentido com que Plutarco a usa. Na Vida de Péricles, está sobretudo relacionada com acçóes de ordem moral, isto é, com o controle de reacçóes que decorrem de determinados sentimentos - mais ou menos impulsivos e irracionais, mas que nada têm a ver com necessidades físicas.

$\mathrm{O}$ conceito que segue mais de perto a teorização de Aristóteles é talvez a praotes, definida como meio-termo entre o extremo das paixóes e o da apatia ${ }^{37}$. Aparece muitas vezes relacionada com a legalidade em contraste com a crueldade, violência ou tirania e resulta de um esforço consciente: na verdade, aquele que a possui e actualiza está a reprimir reacçóes meramente emocionais e instintivas que substitui por outras mais racionais - custa a crer que Péricles, ao ser apelidado de cobarde, não tivesse vontade de reagir. Isso comprova que a praotes se aprende, que requer muito esforço para se sobrepor a instintos, logo, que não é algo de apenas inato; trata-se da razão que controla os sentimentos.

Em jeito de síntese, poderemos dizer que, segundo Plutarco, Péricles era uma pessoa com boa reputaçáo

${ }^{37}$ Martin JR. (1960: 65-73). 
e prestígio, embora, como o comum dos mortais, não fosse totalmente irrepreensível ${ }^{38}$. Mas, pela sua doçura de carácter e moderação ${ }^{39}$ e consequente imperturbabilidade, pela grandeza de alma e elevação de sentimentos, pela dignidade na conduta, pela força de vontade e pela persistência correspondente, pela perspicácia, demarcava-se da generalidade dos homens do seu tempo e dos séculos seguintes. Outras características faziam dele um ser especial: o sentido de justiça, a liberalidade, a incorruptibilidade e, inclusive para alguns, a majestade que emanava do seu comportamento e da própria maneira de ser.

O prestígio que possuía entre os cidadãos resultava das suas virtudes e permitia-lhe exercer a autoridade exigida a um homem de Estado, para que pudesse tomar todas as medidas que deveriam conduzir a uma melhoria das condiçôes de vida do povo.

Havia, porém, quem lhe criticasse o orgulho, o desprezo pelos outros e a arrogância.

Esta disparidade na forma de encarar o comportamento de Péricles remete-nos de imediato para as reflexôes de Aristóteles na Ética a Nicómaco: como nos diz o Estagirita, a fronteira entre o que se pode considerar uma virtude ou um defeito é muito

${ }^{38}$ Ao fazer esta afirmação, também Plutarco (Per. 10. 7) mostra bom-senso, já que nenhum ser humano é perfeito.

39 Para Aristóteles (Ética a Nicómaco 1106b 27), a principal característica da virtude é o facto de ela corresponder ao meio-termo. Tendo em conta que a moderação é a característica de Péricles que Plutarco mais evidencia e que, de uma maneira ou de outra, influencia toda a acção do estadista, podemos interpretá-la como sendo um dos atributos essenciais para se ser superior. 
ténue. Logo, qualquer qualidade tem um ponto de equilíbrio central. A leitura dessa medida pode originar, consequentemente, elogio ou censura, pois quem a avalia pode interpretá-la, respectivamente, como mais próxima do que é desejável ou não. 


\section{TÁBUA CRONOLÓGICA ${ }^{\mathrm{I}}$}

\section{Grécia/Vida de Péricles}

\section{Século V A.C.}

ca. 495-90 Nascimento de Péricles, filho de Xantipo e Agariste (3. 1-2) ${ }^{2}$.

490 Primeira expedição persa contra Atenas, liderada por Dario. Batalha de Maratona, derrota persa.

488-87 Guerra entre Atenas e Egina.

485-84 Ostracismo de Xantipo, pai de Péricles.

480 Segunda expedição persa contra a Grécia, liderada por Xerxes. Batalha das Termópilas. Batalha naval de Artemísio sem um vencedor evidente. Vitória grega na batalha naval de Salamina.

479 Batalha de Plateias e Mícale. Início da reconstrução de Atenas.

478-77 Constituição da Liga de Delos.

ca. 472 Ostracismo de Temístocles que se exila em Argos (7.1).

472 Representação da peça Os Persas de Ésquilo, tendo como corego Péricles.

1 Para o estabelecimento desta cronologia, baseámo-nos sobretudo nas cronologias fixadas por P. A. Stadter (1989: 357 358) e A. Pérez Jiménez (1996: 2 - 59).

${ }^{2}$ Estas referências dizem respeito à Vida de Péricles. 
ca. 470 Início da actividade política de Péricles (7.3-4). 470-60 Construção do templo de Zeus em Olímpia.

463 Processo contra Címon, no qual Péricles se apresenta como principal acusador (10.6).

462-61 Reforma do Areópago por Efialtes: redução o poder deste tribunal (7.8). Início da influência política de Péricles.

461 Ostracismo de Címon (9.2-5). Assassinato de Efialtes (10.7-8).

460-445 Primeira Guerra do Peloponeso, entre Atenas e Esparta.

ca. 455-4 Casamento de Péricles com a ex-mulher de Hiponico (24.8).

454 Sucessos de Péricles no Golfo de Corinto (19.1).

ca. 454-3 Nascimento de Xantipo, filho de Péricles (24.8).

ca. 453 Transferência para Atenas do tesouro da Liga de Delos, antes depositado nesta ilha (12.1).

ante 451 Nascimento de Páralo, filho de Péricles (24.8).

451-50 Péricles promove a lei que priva os filhos bastardos de cidadania (37.3-4).

450-49 Morte de Címon em Chipre (10.8).

449 Paz de Cálias, resultado do tratado entre a Liga de Delos e a Pérsia (17).

448 Segunda Guerra Sagrada (21. 1-2). 
447 Início da construção do Pártenon (13.7). Derrota ateniense na batalha de Coroneia (18.3). Expedição de Péricles ao Quersoneso (19.1).

446-45 Celebração da paz dos trinta anos entre Atenas e Esparta (24.1).

443 Ostracismo de Tucídides, filho de Melésias (16.3). ante 440 Nascimento de Péricles, filho de Aspásia e de Péricles (24.10).

440-39 Guerra de Samos (26. 2-28).

438 Fundação de Anfípolis na Trácia (11.5).

438-37 Consagração da estátua criselefantina de Atenas Pártenos (13.14).

437-32 Construção dos Propileus, entrada monumental da Acrópole (13.12-13).

ca. 435 Expedição de Péricles ao Mar Negro (20.1-2).

433 Primavera: Regresso de Tucídides, o filho de Melésias. Encontro dos Peloponésios em Esparta (29. 4-6).

432-31 Inverno: última embaixada a Atenas (29. 7-30). Oposição de Péricles à anulação do "decreto contra Mégara”, que interditava o comércio com esta cidade $(30.2 ; 31.1 ; 32.6)$.

431 Maio: Invasão da Ática pelo exército da Simaquia do Peloponeso (33.4). Verão: Expedição ateniense contra o Peloponeso. Expulsão dos Eginetas (34.2). 3 de Agosto: Eclipse solar (35.2). Outono: 
Invasão ateniense de Mégara (34.4).

430 Primavera: deflagar da peste em Atenas (34.5). Segunda invasão ática do Peloponeso. Expedição de Péricles contra Epidauro (35.1-3). Verão: Destituição de Péricles (35.4). Morte dos filhos de Péricles, Xantipo e Páralo, da irmã de outros familiares (26.6-8).

429 Reeleição de Péricles (37.1-2). Pedido de cidadania para o filho bastardo do estadista (37.5). Outono: Morte de Péricles (38). 
VIDA DE PÉRICLES 
(Página deixada propositadamente em branco) 
1. 1. César ${ }^{1}$, ao ver em Roma alguns estrangeiros ricos a passear e a acarinhar cachorritos e macaquinhos que traziam ao colo, perguntou, ao que parece, se no país deles as mulheres não tinham filhos ${ }^{2}$. Repreendeu assim, como um verdadeiro líder, os que desperdiçam com animais o afecto e a ternura que por natureza existem em nós e que se destinam às pessoas.

2. Ora, já que a nossa alma possui um desejo intrínseco de aprender e observar, não é razoável censurar os que usam esse dom para ver e ouvir coisas sem qualquer valor e negligenciam o que é bom e útil?

Para os sentidos, que recebem passivamente a impressão do que os rodeia, existe talvez a necessidade de contemplar tudo o que se lhes apresenta, seja útil ou inútil. Mas, quanto à razão, cada um, se assim o quiser, tem a capacidade natural de a utilizar, de a guiar sem tréguas ou de mudar facilmente para o que lhe pareça melhor. Em consequência, devemos procurar o melhor não só para o contemplar, mas também para nos alimentarmos da sua contemplação.

${ }^{1}$ Augusto (63 a.C. - 14 d.C.) incentivou o matrimónio e a natalidade, concedendo subsídios aos que tinham filhos e aplicando multas aos que se não casavam (cf. Suetónio, Augusto 34).

${ }^{2}$ Esta frase é atribuída por Ptolomeu (FGrHist 234 F 8) a Masinissa, rei da Numídia, que assim interpelou uns sibaritas que compravam macacos. 
3. Assim como a cor apropriada ao olho é aquela cujo tom brilhante e alegre reaviva e alimenta a visão ${ }^{3}$, do mesmo modo é preciso aplicar o pensamento em motivos dignos de contemplação que, pelo seu interesse, o incitem à prática do bem.

4. Tais motivos encontram-se nos actos virtuosos, que despertam nos que os observam certa emulaçáo e desejo que induz à imitação.

Noutros casos, à admiração do feito não se segue de imediato o impulso de cometê-lo. Mais ainda, é frequente apreciarmos a obra, mas desprezarmos o artífice, como é o caso dos perfumes e dos tecidos de cor púrpura, com os quais nos deleitamos, mas os perfumistas e os tintureiros, consideramo-los servis e vulgares 4 .

5. Por isso, com razão, Antístenes ${ }^{5}$ ao ouvir que

${ }^{3}$ Como refere Stadter (1989: 55), Plutarco deixa transparecer aqui a doutrina óptica de Platáo (Timeu 45b-e), segundo a qual existe dentro de cada indivíduo um fogo que se reaviva se receber pelos olhos a luz do fogo exterior.

${ }^{4}$ Parece que a visão negativa dos perfumes e das tintas era corrente no mundo antigo (Heródoto 3. 22; Xenofonte, Banquete $2,3)$ e que resultava da alteraçáo antinatural que produziam (cf. Dio Crisóstomo 7. 117). Consta que o próprio Sólon (Aristóteles, Constituição de Atenas 612a, 687a) terá promulgado uma lei contra os vendedores de perfumes e que os Lacedemónios expulsavam de Esparta os fabricantes de unguentos (porque deterioravam o azeite) e os que tingiam a lã (porque corrompiam o seu branco natural). Em Górgias 465b-c, Platão confirma a opinião pouco favorável dos intelectuais em relação à cosmética.

${ }^{5}$ Este filósofo (ca. 445 - 360 a.C.) foi discípulo de Górgias e, mais tarde, também de Sócrates e autor de diálogos socráticos. É considerado o fundador da Escola Cínica. Ele critica não a acção de tocar flauta propriamente dita, mas o facto de se fazer disso uma profissão. 
Isménias 6 era um bom flautista, comentou: "mas como homem não presta, de outro modo não seria um bom flautista”. 6. E Filipe observou ao filho depois de uma execução com melodia e com arte durante um banquete: "Não tens vergonha de tocar assim tão bem?" Pois é suficiente que um príncipe dispense algum do seu tempo livre a ouvir os que tocam e já muito concede às musas como simples espectador dos que competem em tal matéria.

2. 1. O empenho em ocupaçôes vis evidencia em si mesmo, no esforço que dispensa a essas inutilidades, indiferença pelo que é nobre. E a nenhum jovem de boa índole, por ter visto a estátua de Zeus em Pisa ou de Hera em Argos, passou pela cabeça tornar-se um Fídias ${ }^{7}$ ou um Policleto ${ }^{8}$; nem aspirou a ser um Anacreonte,

${ }^{6}$ Flautista tebano (cf. Plutarco, Obras Morais 632c; Demétrio 1. 6). De boa família, Plutarco teve acesso a uma anedota que o aponta como o melhor flautista (as suas melodias eram tocadas nas trirremes e nas fontes; cf. Plínio, História Natural 37. 6-7).

${ }^{7}$ Arquitecto, escultor e pintor ateniense do século V a.C. Foi amigo de Péricles e morreu na prisão (vide infra Per. 31). Os seus trabalhos mais famosos são estátuas de deuses (em madeira, com trajes de ouro e com os membros que ficavam a descoberto revestidos de marfim), nomeadamente de Atena Parthenos e a de Zeus (de Pisa ou Olímpia). Para outras informaçóes relativas à escultura grega, leia-se, por exemplo, Barron (1981); WOOFORD (1982).

${ }^{8}$ Arquitecto e escultor do século $\mathrm{V}$ a.C., natural de Argos. Dentre as suas obras, destacam-se a estátua criselefantina de Hera e o Doríforo, que é considerado o cânon da escultura clássica.

${ }^{9}$ Poeta lírico do século VI a.C., natural de Teos e considerado na Antiguidade um poeta erótico que tentou sempre observar a moderação tipicamente grega, algo que muitos dos seus seguidores não conseguiram fazer. 
Filémon ${ }^{10}$ ou Arquíloco ${ }^{11}$ por gostar dos seus poemas. É que, mesmo que uma obra nos encante pela sua graciosidade, náo é obrigatório que o seu criador se imponha à nossa estima.

2. De onde resulta que não são úteis aos que as contemplam obras deste género, que não provocam o desejo de imitação nem o entusiasmo que estimula a ambição e a ânsia de igualá-las.

Em contrapartida, a virtude nas acções é de tal maneira estimulante que, ao mesmo tempo que se admiram os actos, se deseja imitar os seus autores. 3 . $\mathrm{Na}$ verdade, as benesses que a Sorte nos proporciona, desejamos possuí-las e gozá-las; as que nos concede a Virtude, queremos praticá-las. As primeiras, pretendemos recebê-las dos outros; estas, que outros as recebam de nós. 4. É que o Bem cria, em relação a si próprio, um estímulo activo ${ }^{12}$ e de imediato inspira um

10 Principal representante da Comédia Nova depois de Menandro, a ponto de ter servido de modelo a Plauto em Mercator, Trinummus e Mostelaria. Pensa-se que seja oriundo de Solos, na Sicília, ou de Siracusa e que tenha vivido entre ca. 365-263 a.C.

${ }^{11}$ Natural de Paros (séc. VII a.C.), filho bastardo de um certo Telésicles, colonizador de Tasos e de máe escrava. De um modo geral, era a realidade que inspirava a sua poesia, onde marcas do individualismo típico da época arcaica surgem a cada passo. Ficou famoso pelos seus iambos e elegias, nos quais desvalorizava as concepçôes tradicionais, nomeadamente o ideal de beleza heróica (cf. fr. 60 Diehl). Serviu como mercenário estrangeiro para poder sobreviver, por isso mesmo define-se como sendo um servo de Ares conhecedor dos dons das musas (cf. fr. 1 Diehl). Os poetas que o Queroneu invoca neste passo são provavelmente seleccionados pelo conteúdo satírico ou lascivo das suas obras.

12 Trata-se de uma conhecida doutrina platónica exposta em Banquete 208-212 e em Fedro 250 sq. 
impulso à acção; actua sobre quem o contempla não como um modelo ideal, mas pelo testemunho da sua actuação efectiva incentiva à determinação.

5. Pensámos, por isso, persistir na descrição das vidas e compusemos este décimo livro que engloba a vida de Péricles e a de Fábio Máximo, que desenvolveu uma longa luta contra Aníbal. Eram estes homens semelhantes em diversas qualidades, principalmente na moderação, no sentido de justiça e na capacidade de controlar a imponderação dos cidadãos e dos seus colegas, tornando-se muito úteis às suas pátrias. É que é possível, a partir deste relato, avaliar se apontamos na direcção correcta.

3. 1. Péricles era da tribo de Acamante, do demo de Colarges, de família e de descendência de primeira nobreza, quer da parte do pai, quer da da mãe. 2 . Xantipo, o vencedor sobre os generais do Rei persa em Mícale, casou-se com Agariste, sobrinha de Clístenes, aquele que com dignidade expulsou os Pisistrátidas e pôs fim à tirania; além disso, estabeleceu leis e instituiu uma constituição excelente para o incremento da harmonia e da segurança. 3. Depois de sonhar ${ }^{13}$ que tinha dado à luz um leão, poucos dias mais tarde, Agariste deu à luz Péricles, de aspecto físico em tudo o mais irrepreensível, mas de cabeça alongada e desproporcionada. 4. Por isso, quase todas as suas estátuas o representam de elmo: decerto os artistas não queriam ofendê-lo. Por seu lado, os poetas áticos chamavam-lhe cabeça de cebola

${ }^{13}$ Vide supra Introdução à Vida de Péricles p. 25. 
(esquinocéfalo): é que há um tipo de cebola ${ }^{14}$ a que também é dado o nome de schinon.

5. De entre os cómicos, Cratino, em Quirones, diz: "A Desordem e o velho Cronos uniram-se para gerar um tirano todo-poderoso, a quem os deuses chamam amontoador de cabeças"; e de novo em Némesis: "Vem, ó Zeus hospitaleiro e cabeçudo" ${ }^{15}$. 6. E Teleclides ${ }^{16}$ diz também que às vezes "de mãos atadas perante os assuntos de Estado, sentava-se na Acrópole, com dores de cabeça; outras vezes daquela tola de palmo e meio soltava-se-lhe uma arruaça monumental”. 7. Êupolis, em Demos ${ }^{17}$, enquanto se informava acerca de cada um dos líderes que regressavam do Hades, como Péricles foi o último a ser nomeado, comenta: "eis que trouxeste agora dos Infernos o cabecilha da malta lá de baixo".

4. 1. A maioria concorda em que o seu professor de música foi Dámon ${ }^{18}$, cujo nome, dizem, deve

${ }^{14}$ Refere-se à urginea maritima, género de planta herbácea com um bolbo grosso, de forma oval, bastante largo (com cerca de 15 $\mathrm{cm}$ de diâmetro) e podendo atingir o peso de $7 \mathrm{~kg}$.

${ }^{15}$ Segundo Heródoto, Histórias 5. 66. 1, Zeus Cário era venerado pela família de Iságoras, facto que permite ao comediógrafo estabelecer um paralelo entre aquele e Péricles, sugestivo do perfil tirânico e antidemocrático do estadista.

16 Comediógrafo que parece ter obtido três vitórias nas Dionísias Urbanas e quatro nas Leneias. Chegaram até nós alguns títulos como Anfictióes, Hesiodos, Castigo, Pritanes e fragmentos que sugerem a orientação política das suas críticas.

${ }_{17}$ Peça que data de 412 a.C., isto é, já bastante posterior à morte de Péricles, período em que a gravidade da situação ateniense era tal que o governo do Alcmeónida acabou por ganhar uma conotaçáo paradigmática.

${ }^{18} \mathrm{O}$ filho de Damónides (infra 9. 2) foi discípulo de Pródico 
pronunciar-se com a primeira sílaba breve. Aristóteles, porém, afirma que foi com Pitoclides ${ }^{19}$ que ele estudou música. 2. Dámon, que era um sofista eminente, parecia esconder-se sob o nome da música, ocultando ao público o seu verdadeiro talento; a Péricles, como a um atleta da política, foi ele que lhe serviu de treinador e mestre. 3 . Contudo, não passou despercebido que Dámon se servia da lira como pretexto; acabou condenado ao ostracismo como um intriguista e partidário da tirania, oferecendo matéria aos cómicos. 4. Por exemplo, Platão [Cómico] criou uma personagem que lhe pergunta o seguinte (fr. 207 K.-A.):

Antes de mais, diz-me cá uma coisa, por favor, porque tu, ao que se comenta por ai, foste como um Quiron a educar Péricles.

5. Péricles foi também discípulo de Zenão de

e amigo de Sócrates (Platão, Laques 197d). Foi muito conhecido pela sua teoria sobre a música (que não chegou até nós), matéria na qual se iniciou com Agátocles ou Lâmprocles. Segundo Platão, que também confirma a relação deste com Péricles (Alcibiades 118c), Dámon defendia que a música estava intimamente relacionada com questôes morais (República 400b, 424c): os vários ritmos podiam provocar efeitos diferentes a nível ético. Foi vítima de ostracismo entre 450-440 a.C., mas pouco mais se sabe a seu respeito. Vide Guthrie (1969: 35, n. 1).

19 Segundo esta segunda versão, que Plutarco atribui a Aristóteles (fr. 401 Rose), de acordo com o Estagirita, o professor seria Pitoclides de Ceos, do qual apenas se sabe que foi pitagórico e músico. No entanto, esta informaçăo baseia-se em Platáo (Protágoras 316e, escólio a Alcibiades 118c) e não em Aristóteles, o que pode significar ou que Plutarco confundiu as fontes, ou que esta referência faz parte de uma das muitas obras perdidas. 
Eleia que se ocupava, como Parménides ${ }^{20}$, das ciências e desenvolveu uma habilidade especial para refutar o adversário e para o reduzir à perplexidade com argumentos contraditórios, como mencionou Tímon de Fliunte $^{21}$ em qualquer parte com estas palavras: "Que grande força tem a língua de dois gumes de Zenão, que não dá tréguas, sempre a atacar tudo e todos."

6. Mas quem mais se relacionou com Péricles e lhe incutiu uma majestade e uma grandeza de alma capaz de suplantar qualquer demagogia, numa palavra, quem lhe inspirou e aperfeiçoou a dignidade de carácter foi Anaxágoras de Clazómenas, que os homens de então proclamavam como a própria Inteligência ${ }^{22}$ personificada, quer por lhe admirarem a enorme e excepcional perspicácia revelada no estudo da natureza, quer por ter sido o primeiro de entre todos a determinar, como origem da ordem universal, não o acaso ou a necessidade, mas a Inteligência pura e simples, que separou as substâncias com elementos em comum ${ }^{23}$ da massa caótica dos restantes.

${ }^{20}$ O pré-socrático Parménides de Eleia (ca. 510 - 430 a.C.) compôs um poema filosófico Sobre a Natureza, no qual definia conceitos como verdade, ser, imutabilidade e aparência. Vide Guthrie (1969: 1 sq.).

${ }^{21}$ Filósofo céptico (320 e 230 a.C.), cuja obra mais famosa é Silloi, constituída por três livros de hexâmetros satíricos contra os filósofos, que dedicou a Xenófanes, de quem era admirador. Vide Guthrie (1969: 336).

${ }^{22} \mathrm{O}$ termo aqui usado é nous ou noos. Cf. Introdução, n. 14.

23 Consta que homeomeria seria o termo utilizado no sistema de Anaxágoras para designar os elementos homogéneos que, desenvencilhados do caos, foram separados dos elementos heterogéneos, com os quais estavam dantes confundidos. Mas o termo não ocorre nos fragmentos de Anaxágoras que chegaram até nós. Sobre este assunto, leia-se Guthrie (1969: 325-326). 
5. 1. Péricles, que admirava extraordinariamente este homem, enchia-se daquilo que se chama "filosofia pura" e "especulação fundamental". Daí lhe advinha não apenas, ao que parece, distinção de espírito; mas também um discurso elevado e isento de vulgaridades e de ridicularias de mau tom; um rosto austero que não se abria a um sorriso; tranquilidade no andar e modéstia no vestir, que nunca se alteravam com a emoção dos discursos; a modulação da voz imperturbável; e outras tantas qualidades que causavam a todos admiração.

2. Certa vez, por exemplo, foi insultado e injuriado na ágora por um homem infame e insolente. Suportou-o todo o dia em silêncio, enquanto despachava assuntos urgentes que tinha a tratar e à tarde foi tranquilamente para casa, ainda seguido pelo sujeito que lhe dirigia todo o tipo de impropérios. Quando já estava para entrar, como havia escurecido, ordenou a um dos escravos que pegasse num archote para escoltar e acompanhar o homem a casa.

3. O poeta Íon ${ }^{24}$, no entanto, fala do contacto arrogante e um tanto altaneiro de Péricles e afirma que ele misturava ao seu orgulho muito desprezo e desdém

${ }^{24}$ Íon (ca. 490-424 a.C.) foi um dos poucos tragediógrafos que os Alexandrinos incluíram no cânone, ao lado de Ésquilo, Sófocles e Eurípides. Mas a sua produção escrita estendeu-se por outros domínios, nomeadamente o elegíaco, o filosófico (Triagmo, onde defende que a realidade é trinitária) e o histórico (História da Fundação de Quios). Uma das suas obras mais famosas é Epidemias, que tratava das viagens do seu autor e também das visitas de homens ilustres à sua terra natal. $\mathrm{O}$ seu estilo revela gosto pelo retrato e pela anedota. Vide Lesky (1995: 439-441); GUTHRIE (1969: 158). 
pelos outros; elogia, em contrapartida, Címon ${ }^{25}$, pelo tacto, delicadeza e elegância que punha nas relaçóes humanas. Mas deixemos Íon que pretende que a virtude, como numa sequência trágica ${ }^{26}$, tenha sempre algo de drama satírico. Zenão ${ }^{27}$, pelo contrário, exortava aqueles que chamavam à majestade de Péricles ânsia de prestígio e orgulho a terem também eles essa mesma ânsia, pois a procura produz imperceptivelmente a emulação e o hábito do bem.

${ }^{25}$ Címon, nascido em 510 a.C., era marido de Isódice (neta do alcmeónida Mégacles) e filho de Hegesípile e de Milcíades (condenado em 489 a.C. por Xantipo, pai de Péricles, a uma multa de cinquenta talentos que só foi paga quando a filha, Elpinice, casou, após a morte do pai na prisão, com Cálias, o homem mais rico de Atenas). Assumiu o comando da armada ateniense em $476 \mathrm{e}$ manteve-o até 462 a.C., altura em que regressou de Itome, afastado pelos Espartanos que não estavam satisfeitos com o desempenho dos aliados atenienses. Embora partidário da aristocracia que o apoiava, era bem visto pelas massas por causa das suas qualidades bélicas e consequentes vitórias. Procurou preservar a aliança entre Atenas e Esparta, motivo pelo qual foi acusado de laconismo e punido com o exílio (461 a.C.). Morreu em combate (vide infra 10. 8) no ano de 449. Parece que as opiniōes de Íon favoráveis a Címon resultam da amizade que existia entre ambos: cf. Plutarco, Cimon 5. 3, 9. 1-6, 16. 10.

${ }^{26}$ Plutarco diz com isto que, para Íon, a virtude não deve ser sempre séria e que deve haver espaço para o riso: a tragédia grega é exemplo desse pensamento, já que, à trilogia, se seguia o drama satírico, que frequentemente tratava, em tom burlesco, o mesmo tema das tragédias.

${ }^{27}$ Possivelmente não Zenão de Eleia (referido em Per. 4. 5), mas Zenão de Chipre (ca. 336-261 a.C.), o fundador do Estoicismo, a quem muitos apotegmas deste género são atribuídos. Cf. GuTHrie (1969: 19 sq); STADTER (1989: 80-81). 
6. 1. Não foram estes os únicos benefícios que Péricles tirou do convívio com Anaxágoras; parece que se tornou também superior à superstição que o espanto diante de certos fenómenos celestes suscita nos que não conhecem as suas causas e nos que, a propósito de assuntos divinos, enlouquecem e se inquietam por nada saberem a esse respeito; o conhecimento da natureza elimina esses temores e faz nascer, em vez da superstição mórbida, a piedade fundamentada em expectativas lógicas.

2. Diz-se que uma vez trouxeram da sua propriedade a Péricles a cabeça de um carneiro de um só corno e que o adivinho Lâmpon ${ }^{28}$, quando lhe examinou o corno robusto e sólido implantado no meio da testa ${ }^{29}$, disse que sendo dois os partidos poderosos que existiam na cidade, o de Péricles e o de Tucídides ${ }^{30}$, a autoridade

${ }^{28}$ Este adivinho ateniense era amigo de Péricles e participou, em 443 a.C., na expedição à Magna Grécia que tinha por intuito fundar a colónia de Túrios. Os comediógrafos não perderam a oportunidade de atacá-lo por ser um mantis (aquele que é considerado capaz de interpretar os sinais dos deuses, mas que náo ocupa cargo oficial na máquina do Estado) e um grande comiláo, já que tinha o direito de comer no Pritaneu a expensas públicas (cf. Aristófanes, Nuvens 332, Aves 521, 987-988, Cratino, fr. 66 K.-A.).

${ }^{29}$ As anomalias da natureza eram consideradas prodígios que poderiam revelar os desejos e as intençóes dos deuses. O corno era visto como um símbolo de poder e de liderança.

${ }^{30}$ Tucídides, filho de Melésias, foi um orador exímio, escolhido pelos aristocratas para ocupar o lugar que a morte de Címon - de quem era parente por afinidade - deixara vago na oposição a Péricles. Apesar de ter sido uma figura importante na política da década de 440 a.C., pouco se sabe a seu respeito, sobretudo porque foi muitas vezes confundido com homónimos, nomeadamente o historiador. Uma das suas principais tentativas para derrubar a influência do 
viria a caber apenas a um, aquele a quem o sinal tinha sido transmitido. Anaxágoras, por sua vez, aberta a cabeça, mostrou que o cérebro não enchia o crânio, mas tinha afunilado, pontiagudo como um ovo, de toda a cavidade em direcção ao local onde tinha início a raiz do corno. 3 . Neste momento, Anaxágoras mereceu a admiração dos presentes, mas, pouco depois, foi Lâmpon a conquistá-la, quando, destituído Tucídides, todos os interesses do povo, sem excepção, ficaram sob o controlo de Péricles. 4. Nada impedia, penso eu, que quer o filósofo, quer o adivinho estivessem correctos: um compreendeu bem a causa, o outro, o propósito. $\mathrm{Na}$ verdade, o papel de um é observar porque nasceu e como se desenvolveu tal fenómeno; o do outro é predizer com que finalidade ocorreu e o que significava.

5. Os que afirmam que a descoberta da causa é a destruição do sentido do sinal não compreendem que, com os símbolos divinos, estão a rejeitar também os símbolos convencionais, o toque dos gongos, a luz das tochas ou a sombra dos relógios de sol; cada um deles tem a sua causa, mas foi preparado para simbolizar qualquer coisa $^{31}$. Mas isso é sem dúvida matéria de outro estudo.

estadista, que crescia visivelmente a cada dia, consistiu no ataque ao programa de reconstruçáo da cidade. No entanto, o único poder que conseguiu abalar foi o seu próprio, já que acabou votado ao ostracismo, deixando o caminho livre para o seu adversário e para o florescimento da democracia. Segundo Diógenes Laércio, terá sido Tucídides a acusar Anaxágoras de impiedade (infra Per. 32. 5), por rivalidade com Péricles.

${ }^{31}$ Desde sempre o homem teve necessidade de descrever o que o rodeia através de signos convencionais, aos quais atribui diferentes significados, também eles convencionados. Plutarco póe em igual plano os símbolos divinos e os humanos, mostrando que nesta 
7. 1. Péricles, quando era jovem, temia enfrentar o povo. É que, segundo a opinião geral, era parecido com o tirano Pisístrato nos traços, na voz agradável e no estilo ágil e fluente do discurso; aos mais velhos tão forte semelhança deixava-os atónitos. 2. Como era rico, membro de uma família ilustre e tinha amigos muito poderosos, temia ser condenado ao ostracismo e náo participava na vida política, mas nas expediçôes militares era um homem corajoso e empreendedor.

3. Quando Aristides morreu e Temístocles foi exilado, as expediçóes militares retinham Címon muito tempo fora da Grécia ${ }^{32}$; nessas circunstâncias,

matéria não se podem separar as águas: ambos têm por objectivo comunicar, transmitir um significado e todos foram criados para significar uma realidade específica. Recusar uns é pôr em causa todos.

${ }^{32}$ Durante as cerca de duas décadas que se seguiram às batalhas de Maratona (490 a.C.), Salamina (480 a.C.) e Plateias (479 a.C.) decisivas para esbater o perigo persa -, Aristides (ca. 540-468 a.C.) e Temístocles (ca. 528-462 a.C.) ocuparam posiçóes de relevo na vida política de Atenas, pois tinham dado grande contributo para a derrota do inimigo: o primeiro alcançara a glória em Maratona; o segundo, além de ter sido o responsável pela organização da frota que viria a ser a mais poderosa da Grécia, tinha sido o comandante da batalha de Salamina. Aristides, conhecido pelo seu sentido de justiça e rigor, foi incumbido da constituição de uma aliança entre Atenas e os seus aliados que tinha por objectivo fazer frente ao inimigo bárbaro: com a Simaquia de Delos, os Gregos pretendiam estar preparados para eventuais retaliaçóes e libertar os muitos Helenos que ainda se encontravam sob o jugo do Rei. Durante esta fase, Aristides foi também o comandante da frota de Atenas. Só em 476 a.C. é que Címon, até então seu subordinado, o substituiu nesta função, passando a ausentar-se com mais frequência de Atenas. Quanto a Temístocles, depois de ter sido arconte em 493 a.C. (período no qual organizou a frota), não voltou a ser eleito 
Péricles decidiu associar-se entusiasticamente ao povo, preferindo, em detrimento dos ricos e das minorias, o lado das maiorias e dos pobres, contra a sua própria natureza que era muito pouco populista. 4. Mas, ao que parece, como temia encontrar-se sob suspeita de tirania, e como via as tendências aristocráticas de Címon e as simpatias de que gozava entre os nobres, voltou-se para a multidão, para garantir a própria segurança e força contra o rival.

5. Imediatamente modificou o modo de vida. Era visto, na cidade, a caminhar numa única rua, a que conduz à ágora e ao conselho; renunciou aos convites para banquetes e a todas as outras relaçóes familiares e sociais, de modo que, durante todo o longo período de tempo em que esteve no poder, nunca foi jantar a casa de um amigo, excepto quando o seu primo Euriptólemo deu uma festa de casamento; mesmo aí ficou até às libaçóes ${ }^{33}$ e saiu em seguida. 6. É que as festas são terríveis para manter a dignidade e é difícil conservar na convivência a seriedade que leva à boa reputação. Porém, a verdadeira virtude tanto mais bela é quanto mais evidente se torna, e, assim, nada nos homens superiores pode causar tanta admiração nos de fora quanto o seu dia-a-dia nos que com eles convivem.

7. Para evitar a exposição constante e a consequente saturaçáo, aproximava-se do povo a intervalos; não falava

para nenhum cargo importante e terminou os seus dias no exílio, acusado de se ter aliado aos Persas (472 a.C.).

33 As libaçôes aos deuses marcavam o final da refeiçấo propriamente dita. Nesta altura, era trazido o vinho para o symposium e só entáo os convivas começavam a beber. 
sobre um assunto qualquer e nem sempre comparecia em público. Como a trirreme Salaminia ${ }^{34}$, segundo Critolau ${ }^{35}$, Péricles guardava-se para as grandes ocasióes e as restantes resolvia-as por meio dos amigos e outros oradores.

8. Um deles foi, ao que se diz, Efialtes ${ }^{36}$, que arrasou o poder do conselho do Areópago, dando a beber, nas palavras de Platão ${ }^{37}$, aos cidadãos liberdade grande e da genuína. Dizem, os comediógrafos que, graças a ela, o povo empinado que nem um cavalo, "não

${ }^{34}$ A Salamínia e a Páralo eram trirremes sagradas com tripulaçóes de elite, que se usavam em missóes especiais, nomeadamente nas deslocaçóes para consultas de oráculos ou para ir buscar generais, como aconteceu, em 415 a.C., quando Alcibíades regressou da Sicília (Tucídides 6. 53. 1).

Plutarco defendia o método de trabalho de Péricles: o estadista não tem condiçốes de fazer tudo o que é necessário para o bom funcionamento da vida de um Estado sozinho. Tem de trazer todos os assuntos controlados e delegar funçóes, reservando para si as tarefas mais importantes.

${ }^{35}$ Filósofo peripatético do séc. II a.C., natural de Fasélis. Já em idade avançada, tomou parte, com o académico Carnéades e com Diógenes Estóico, na expedição de filósofos a Roma em 156-155 a. C. Cf. Guthrie (1969: 62 n. 1).

${ }^{36}$ Deste estadista ateniense, conhecido, como Péricles, pela sua incorruptibilidade, sabe-se muito pouco. Filho de Sofónides, foi um dos poucos líderes atenienses que não era rico. Substituiu Temístocles na liderança dos populares e, consequentemente, teve em Címon o seu principal opositor. Foi responsável pela supressáo de poderes do Areópago em 462 a.C. (Per. 9. 5, 10. 7). Mas, os aristocratas, pouco satisfeitos com o sucedido, mandaram assassiná-lo no ano seguinte (Per. 10. 8). As más-línguas chegaram a responsabilizar Péricles pelo crime (Per. 10. 7). Sobre a reforma do Areópago, uma das últimas medidas para retirar poder da aristocracia e transferi-lo para o povo, leia-se RibeIro FERreIra (1990: 47).

${ }^{37}$ República 562c-d. 
tolerou mais obedecer, mas morde Eubeia e salta sobre as ilhas ${ }^{38 "}$.

8. 1. Ajustando o discurso, como quem afina um instrumento, em harmonia com o seu modo de vida e com a sua grandeza de espírito, era frequente vibrar o tom de Anaxágoras, para derramar uma coloração de ciências da natureza sobre a sua retórica.

2. De facto, "a elevação de pensamento e eficácia de execução que adquiriu”, como diz o divino Platão ${ }^{39}$, "do saber acrescentado aos seus dotes naturais", a que veio somar-se a vantagem de uma qualificação retórica, distinguiu-o muito de todos os outros. 3. Foi daí - é voz corrente - que lhe veio a alcunha; mas alguns pensam que lhe chamavam Olímpico por causa dos monumentos com que embelezou a cidade; outros ainda pela sua autoridade no governo e no comando militar. E não é improvável que essa reputação se deva à combinação de todas as qualidades que possuía. 4. Contudo, as comédias dos poetas do seu tempo que lançavam, em tom sério ou

38 Este verso alude ao tratamento pouco correcto que os Atenienses tiveram em relação aos aliados, nomeadamente a Eubeia, quando esta tentou deixar de pertencer à Simaquia. Atenas usou de uma política de repressão contra todos aqueles que, achando desnecessário manter uma aliança contra o inimigo persa que já não oferecia perigo, quiseram libertar-se do compromisso (vide Ribeiro Ferreira 1990: 131-146). Aristófanes (Nuvens 211-213) apresenta uma anedota semelhante, também relacionada com Péricles: duas personagens estão a observar um mapa da Grécia e uma diz: "Aqui está a Eubeia que, como vês, se estira bem longe, a todo o comprimento". Ao que a outra personagem replica: "Bem sei. Demos-lhe um bom estirão, nós e Péricles."

${ }^{39}$ Fedro 270a. 
a rir, muitas bocas contra ele, mostram que o epíteto lhe veio sobretudo do discurso. Afirmam que produzia trovôes e coriscos, quando falava ao povo, e que trazia um raio medonho na língua ${ }^{40} .5$. Recorde-se uma frase de Tucídides, filho de Melésias ${ }^{41}$, proferida por graça, a propósito da capacidade persuasiva de Péricles. Tucídides era aristocrata e foi opositor de Péricles durante muito tempo. Quando, certa vez, Arquidamo ${ }^{42}$, rei de Esparta, lhe perguntou se era ele ou Péricles quem combatia melhor, Tucídides disse: "quando eu o derrubo em combate, ele nega ter caído e leva a melhor, pois altera a opinião de quem assiste".

6. Todavia, o próprio Péricles era de tal modo prudente no discurso, que, sempre que se dirigia à tribuna, suplicava aos deuses que nenhuma palavra inoportuna

${ }^{40} \mathrm{~A}$ constante aproximaçăo feita entre Péricles e Zeus tem uma intenção: tal como Zeus, ao instaurar uma nova ordem, propiciou a decadência da Idade do Ouro, assim Péricles, ao estabelecer uma democracia radical, inaugura uma nova era na qual se verifica um deteriorar progressivo da moral tradicional. Por outro lado, o controlo quase absoluto que Péricles tinha sobre a cidade assemelha-se ao de Zeus no panteáo. Aliás, ao comparar as palavras de Péricles com os raios e coriscos de Zeus, sugere-se na perfeição não só o domínio de Péricles sobre o povo como também a sua capacidade oratória.

${ }^{41}$ Melésias foi um treinador de luta livre muito conhecido no seu tempo. Segundo Platấo (Menéxeno 94c), o gosto por esta actividade era transmitido de geração em geraçấo, pelo que Tucídides terá não só praticado este desporto, como também iniciado os próprios filhos nessa actividade. No entanto, o combate que aqui se refere é provavelmente metafórico. Cf. PodLecki (1987: 39).

${ }_{42}$ Arquidamo II reinou entre 469 e 427 a.C. Foi ele quem comandou as invasóes à Ática durante a Guerra do Peloponeso em 431,430 e 428 a.C., pelo que o primeiro período da guerra recebe o seu nome. Cf. Tucídides 2. 10-12, 18-20. 
para a questão em causa lhe saísse sem querer.

7. Não deixou nada escrito, excepto decretos, e poucos sáo, na verdade, os ditos que dele se recordam ${ }^{43}$, como o que ordena que se retire Egina ${ }^{44}$, como pus do olho do Pireu; ou um outro em que afirmava já ver a guerra a avançar do Peloponeso. 8. E, num dia em que Sófocles ${ }^{45}$, que com ele comandava uma expedição, ao saírem do porto louvou a beleza de um jovem, Péricles censurou-o: - "Sófocles, é preciso que um general não tenha puras apenas as máos, mas também os olhos". 9. Estesímbroto $^{46}$ testemunha que, ao pronunciar, sobre a tribuna, o encómio dos mortos em Samos, ele teria dito que se tinham tornado imortais como os deuses - a esses, náo os vemos, mas, pelas honras que recebem e pelas

${ }^{43}$ Como sendo da autoria de Péricles, apenas se recordam quatro frases em Plutarco, Obras Morais 186c.

${ }_{44}$ Ainda que inicialmente não tenha feito parte da Simaquia de Delos, tornou-se tributária quando em 459 a.C. foi derrotada numa batalha marítima por Atenas (Tucídides 1. 105. 2, 108. 4). E, embora tenha permanecido na Simaquia após a assinatura do tratado de paz em 446 a.C., continuava a queixar-se a Esparta, facto que foi uma das causas da Guerra do Peloponeso (Tucídides 1. 67.2, 139. 1). Em 431 a.C., os Atenienses expulsaram os habitantes desta ilha, que, pela proximidade do Pireu, facilmente podiam bloquear o acesso ao porto, e instalaram lá os seus próprios cidadãos (Tucídides 2. 27. 1). A comparação entre Egina e uma infecção ocular é tanto mais expressiva se tivermos em conta que a conjuntivite era então uma doença muito frequente e impedia a visão de quem dela padecia. Também Egina impedia o total funcionamento do Pireu.

${ }^{45}$ Trata-se do tragediógrafo que, em 441-439 a.C., foi estratego com Péricles na Guerra contra Samos.

${ }^{46}$ Estesímbroto (activo em finais do séc. $\mathrm{V}$ a.C.) foi rapsodo, comentador dos Poemas Homéricos e escreveu também uma obra intitulada Sobre Temistocles, Tucídides e Péricles, onde, com recurso constante a anedotas, ataca esses políticos atenienses. 
graças que concedem, verificamos que são imortais. Ora essas características são comuns aos que morreram pela pátria.

\section{1. Enquanto Tucídides ${ }^{47}$ descreve o governo de} Péricles como aristocrático - sob o nome de democracia, "na prática era o primeiro dos cidadãos quem governava" - muitos outros dizem que pela primeira vez o povo foi induzido por ele às cleruquias ${ }^{48}$, aos subsídios para assistir ao teatro ${ }^{49}$ e à distribuição de compensaçóes pelos serviços públicos ${ }^{50}$; foi por causa das medidas de então que se habituou mal e se tornou esbanjador e libertino,

${ }^{47}$ Tucídides 2. 65. 9.

${ }^{48}$ Nos territórios que foram libertando do domínio bárbaro ou naqueles que tentavam abandonar a Simaquia de Delos, os Atenienses estabeleceram cleruquias, que eram lotes de terras distribuídos aos cidadáos de Atenas. Aí, os próprios clerucos cultivavam as suas propriedades (ou recebiam rendas dos antigos donos que se tornavam seus granjeiros) e exerciam funçóes militares. Os clerucos mantinham a cidadania ateniense, ao contrário do que acontecia nas colónias usuais (apoikiai), que constituíam uma polis totalmente independente da metrópole (cf. Diodoro Sículo 11. 88. 3). No entanto, as cleruquias possuíam órgãos locais de governo, cuja existência é atestada por documentos epigráficos. Sobre este tema, vide Ribeiro Ferreira (1990: 321); Mossé (1992: 111 112).

${ }^{49} \mathrm{O}$ theorikon era o fundo do Estado com que se financiavam as festas públicas e com que se provia o pagamento de dois óbolos aos cidadáos pobres para que pudessem assistir às representaçôes dramáticas. No entanto, a atribuiçẫo desta medida a Péricles é controversa, pois só temos informações sobre este subsídio a partir do século IV (sobre esta problemática, vide STADTER (1989: 111). Assim, é provável que Plutarco se referisse a um aumento do valor do theorikon em sentido global, medida que certamente agradaria ao povo. Sobre este fundo, leia-se Mossé (1992: 474).

${ }^{50}$ Cf. Platão, Górgias 515e, 518e. 
em lugar de ser prudente e trabalhador. Observemos, em função destas acçóes, a causa da mudança de política. 2. No começo, como já se disse, procurou o favor do povo para fazer frente ao prestígio de Címon, a quem era inferior na riqueza e nos bens, com os quais aquele atraía os pobres. Assim oferecia todos os dias uma refeição aos Atenienses necessitados, vestia os mais velhos e tirou as cercas das suas terras para que quem quisesse colhesse os frutos. Péricles, batido por essas medidas demagógicas, volta-se para a distribuição do tesouro público, aconselhado por Damónides de $\mathrm{Ea}^{51}$, como contou Aristóteles ${ }^{52}$. 3. Rapidamente com os fundos para os espectáculos, com os salários dos juízes e com outras mistoforias e subsídios, corrompeu a multidão e usou-a contra o conselho do Areópago, de que ele não fazia parte por não ter obtido em sorte nem o cargo de arconte, nem o de tesmóteta, nem o de arconte-rei ou polemarco ${ }^{53}$. 4. É que estes cargos

${ }^{51}$ Aristóteles apresenta Damónides como influente conselheiro de Péricles que, por esse motivo, foi votado ao ostracismo. Não deve ser confundido, o que aliás Aristóteles faz, com o filho Dámon (Per. 4. 1-4), que também foi conselheiro de Péricles na década de 30. Vide Rhodes (1981: 341).

${ }^{52}$ Constituição de Atenas 27. 4.

53 Principal magistratura da época arcaica e dos princípios do século V a.C., altura em que as reformas de 488-487 a.C. Ihe reduziram a importância. Nesta fase, os arcontes eram já dez: um rei (com funçóes religiosas), um polemarco (com funçóes militares), um epónimo (dava o nome ao ano), seis tesmótetas (encarregados de redigir as leis) e um secretário. Acediam ao cargo por sorteio (que, aliás, era o método mais utilizado de acesso às magistraturas), à razão de um por tribo, com base numa lista de quinhentos candidatos pré-seleccionados dentre os membros das classes censitárias mais elevadas (pentacosiomedinos e cavaleiros). 
eram desde sempre ${ }^{54}$ sorteados e só através deles os que tivessem provado um bom desempenho ${ }^{55}$ ascendiam ao Areópago. 5. Por isso foi sobretudo quando Péricles teve mais crédito entre o povo que destruiu a autoridade do conselho ${ }^{56}$, de tal maneira que the tirou a maior parte das atribuiçóes por intermédio de Efialtes ${ }^{57}$. Mais ainda,

Vide Ribeiro Ferreira (1990: 42, 108-112); Mossé (1992: 5960).

${ }^{54}$ Desde Sólon, segundo Aristóteles, Constituição de Atenas 8. 2. Esta informação, no entanto, contradiz Política 1273b 41-1274a 3 , onde se afirma que Sólon nâo introduziu nenhuma mudança. RHOdes (1981: 272-274).

55 Em Atenas, dokimasia era uma espécie de audiência ou escrutínio prévios que se fazia aos candidatos às magistraturas, quer fossem eleitos quer fossem sorteados, para verificar se dispunham das qualidades necessárias para assumir funçôes (cf. Constituição de Atenas 55. 2-4). Não há, porém, relatos de procedimento semelhante em relação ao acesso ao Areópago. Plutarco usa com frequência o verbo da mesma família mas, aparentemente, sem o sentido que lhe era atribuído em Atenas. É provável que o Queroneu estivesse a pensar em euthynai, a avaliação a que era submetida a administração de um magistrado no final do seu mandato. Vide Ribeiro Ferreira (1990: 103, 323); Mossé (1992: 171).

${ }^{56} \mathrm{O}$ Areópago, cujo nome advém do do local onde o conselho se reunia - a colina dedicada ao deus Ares -, era o órgão de governo mais antigo de Atenas (Plutarco, Sólon 19. 1). Dele faziam parte os que, depois de servirem o Estado como arcontes (cf. supra n. 53), passavam as euthynai (cf. nota anterior). Até 462 a.C., tinha como atribuiçôes julgar os casos de homicídio, supervisionava os cultos oficiais e infracções contra estes e podia punir os magistrados que não desempenhassem convenientemente as suas funçôes. Com a reforma, apenas manteve a jurisdição sobre os homicídios (Filocoro, FGrHist 328 F 64). Os restantes poderes foram distribuídos pelo Conselho dos Quinhentos, pela Assembleia e pelos tribunais. Vide Ribeiro Ferreira (1990: 44-49, 116-118); Mossé (1992: 6062).

${ }^{57}$ As informaçóes sobre a reforma são poucas e muitas vezes controversas. Neste passo, Plutarco apresenta Efialtes como um agente de Péricles. No entanto, em Plutarco (Címon 15. 2) e em 
desterrou, por ostracismo, Címon ${ }^{58}$ como partidário dos Lacedemónios e inimigo do povo, embora este não fosse nem em fortuna nem em linhagem, inferior a ninguém, e tivesse alcançado belas vitórias sobre os bárbaros e enchido a cidade de riquezas e despojos sem conta, como escrevemos na sua Vid ${ }^{59}$. Tal era o poder de Péricles sobre o povo.

10. 1. Então o ostracismo tinha uma duração de dez anos fixada por lei para os exílios. Entretanto, os

Aristóteles (Constituição de Atenas 25. 1-2), é-nos dito que Efialtes age por sua conta e risco, o que é compreensível, já que era o líder dos populares e Péricles apenas um correlegionário. Vide Mossé \& Schnapp-Gourbeillon (1994: 249). Sobre Efialtes, cf. supra n. 36 .

${ }^{58}$ A acusaçáo de laconismo que aqui se salienta resulta da forte admiração que Címon nutria por Esparta, o que é bastante compreensível se tivermos em conta que era um antidemocrata saudosista da oligarquia aí vigente. Plutarco conta que até os seus cavalos tinham nomes lacedemónios (Címon 16. 1), já para não mencionar os dos filhos, também com a mesma origem, facto que o próprio Péricles utiliza como arma de ataque contra o opositor e respectivos filhos (Per. 29. 1-2). Por isso, Címon procurava auxiliar os Espartanos em questôes militares, valendo-se da aliança que ambos os povos haviam celebrado aquando das Guerras Médicas. Mas Atenas, que se sentia cada vez mais confiante no seu poder, já náo estava muito interessada em manter o pacto - basta lembrar que Efialtes tentou impedir (embora sem êxito) que Címon partisse para a Messénia em auxílio dos Lacedemónios em 462 a.C. A insistência de Címon acabou por ser a sua própria desgraça: consta que as tropas sob o seu comando não tiveram o desempenho que os Espartanos esperavam. Como estes começavam a temer o poderio de Atenas, pensaram que essa "falta de êxito" era propositada e dispensaram as forças atenienses. A autoridade de Címon ficou desacreditada e, quando ele tentou opor-se à reforma do Areópago, não foi difícil acusá-lo de laconismo e votá-lo ao ostracismo.

${ }^{59}$ Címon 10. 1. 
Lacedemónios entraram com um grande exército em Tânagra e de imediato os Atenienses marcharam contra eles $^{60}$. Nessa altura Címon regressou do exílio e pegou em armas para combater com os da sua tribo. Queria, por meio de acçóes concretas, livrar-se da acusação de laconismo ao partilhar o perigo com os concidadáos; mas os amigos de Péricles uniram-se e afastaram-no com o pretexto de se tratar de um desterrado ${ }^{61}$. 2. Por isso, parece que Péricles combateu ${ }^{62}$ com toda a valentia naquela batalha e se distinguiu de todos, sem poupar a vida. 3. Todos os amigos de Címon, que Péricles também acusava de laconismo, sucumbiram. Os Atenienses foram tomados de um profundo arrependimento e de saudade de Címon: vencidos junto às fronteiras da Ática, esperavam uma guerra dura na Primavera seguinte. 4. Apercebendo-se disso, Péricles não hesitou em fazer a vontade à multidáo: ele próprio redigiu o decreto que trouxe Címon de volta. Este, depois de ter regressado, estabeleceu a paz entre as duas cidades ${ }^{63}$.

${ }^{60} \mathrm{Na}$ Primavera de 457 a.C. (cf. e. g. Tucídides 1. 107. 2-108. 1). Os Espartanos tinham partido em socorro da Dórida que fora atacada pela Fócida. Cumprido o intento, no regresso a casa, foram atacados em Tânagra pelos Atenienses que suspeitavam das intençóes dos Lacedemónios: temiam um ataque dos defensores da oligarquia incitado pelos antidemocratas de Atenas.

${ }^{61}$ Segundo Plutarco (Címon 17. 5) o Conselho dos Quinhentos suspeitou que Címon quisesse confundir os soldados para ajudar os Lacedemónios. E Tucídides (1.107.4) chega a dizer que alguns oligarcas de Atenas seriam aliados de Esparta na esperança de derrubar a democracia.

${ }^{62}$ A participação de Péricles nesta batalha talvez seja invenção de Plutarco. Vide Stadter (1989: 123).

${ }^{63}$ A data do acordo de paz entre Esparta e Atenas tem sido alvo de grande interesse por parte dos estudiosos modernos, o que levou 
É que os Lacedemónios tinham tanta simpatia por ele, quanto aversão por Péricles e pelos outros líderes populares. 5. Alguns dizem que o regresso de Címon não foi decretado por Péricles antes de, por intermédio de Elpinice, irmã de Címon ${ }^{64}$, ter sido celebrado entre eles um acordo secreto, segundo o qual Címon iria zarpar com duzentos barcos e comandar o exército no exterior para conquistar o território do $\mathrm{Rei}^{65}$, enquanto Péricles exercia o poder na cidade.

6. Parece que já antes Elpinice tinha ganhado a benevolência de Péricles para com Címon, quando este enfrentava uma acusação capital ${ }^{66}$. Nessa altura Péricles era um dos acusadores, proposto pelo povo; quando Elpinice foi ter com ele e suplicou pelo irmão, este disselhe sorrindo: "Elpinice, estás velha, velha demais para te meteres em tais sarilhos ${ }^{67}$ ". No entanto, levantou-se uma

à produçáo de muitos estudos sobre o tema. Vide STADTER (1989: 124-125). Quanto a Plutarco, neste passo e em Címon 17. 8 -18. 1 , segue a versão de Teopompo (FGrHist $115 \mathrm{~F}$ 88), segundo a qual ainda não teriam passado cinco anos desde o início do exílio de Címon, o que faz com que a intervençáo deste tenha tido lugar em 451-450 a.C.

${ }^{64}$ Desconhece-se a fonte desta anedota, que pode ser uma versão modificada de uma outra da autoria de Antístenes. Este autor, entre outras alusóes mordazes que faz à vida sexual de Péricles, afirma que Elpinice teve de pagar o preço do regresso do irmáo (Antístenes 589e).

${ }^{65}$ Trata-se do rei da Pérsia. De acordo com Plutarco (Címon 18. 1) aquele teria assumido voluntariamente esta tarefa na tentativa de evitar a guerra entre os Gregos.

${ }^{66}$ Em Címon 14. 3-5, Plutarco, com base em Estesímbroto (FGrHist 107 F 5), conta que este incidente teve lugar depois da conquista de Tasos (ca. 463 a.C.). Nesta altura, acusaram-no de ter aceitado subornos para não atacar a Macedónia.

${ }^{67}$ Esta anedota tem uma conotação sexual evidente: Elpinice 
única vez para falar, apenas para cumprir a sua obrigação, e logo se retirou, pelo que foi, dentre os acusadores, o que menos prejudicou Címon ${ }^{68}$.

7. Perante esta atitude, como pode alguém crer em Idomeneu $^{69}$ que acusa Péricles de ter morto à traição o líder popular Efialtes, que foi seu amigo e colaborador nas medidas governativas, por inveja e ciúmes da sua reputação? $\mathrm{Na}$ verdade, não se sabe donde tirou essas conclusóes, como se destilasse bílis contra um homem que decerto não era perfeito, mas que tinha um espírito nobre e uma alma sedenta de glória, onde uma paixão tão cruel e selvagem não teria lugar.

8. Efialtes era terrível para os oligarcas e inflexível nas prestaçóes de contas e perseguiçóes contra os que prejudicam o povo. Os inimigos fizeram então uma conspiração contra ele e, às mãos de Aristódico de Tânagra, mataram-no secretamente, segundo disse Aristóteles ${ }^{70}$.

está velha demais para seduzir Péricles.

${ }^{68}$ Plutarco pretende pôr mais uma vez em evidência a praotes de Péricles. É provavelmente por essa razão que o relato do episódio assume contornos totalmente diferentes consoante a personagem que é objecto de biografia: aqui, o Queroneu sugere que Péricles deu pouca importância à oportunidade de prejudicar o adversário; porém, em Címon 14. 5, afirma que aquele soube tirar partido das circunstâncias em benefício da sua carreira. $\mathrm{Na} V i d a$ de Címon, Plutarco parece partilhar da opinião de Aristóteles (Constituição de Atenas 27. 1), que faz coincidir o acontecimento com a primeira vitória política de Péricles antes de se tornar líder dos populares.

${ }^{69}$ Idomeneu de Lâmpsaco (ca. 325-270 a.C.) foi amigo de Epicuro e participou activamente na vida política da sua cidade. Conservam-se fragmentos de três obras com carácter biográfico de sua autoria: Dos Socráticos, Dos Demagogos e História da Samotrácia.

${ }^{70}$ Constituição de Atenas 25. 4. 
Entretanto, Címon morreu em Chipre durante uma campanha.

11. 1. Os aristocratas, ao verem Péricles, como aliás já antes ${ }^{71}$, tornar-se o mais poderoso dos cidadãos, desejavam que houvesse na cidade alguém que se lhe opusesse e que lhe abatesse o poder, de modo que não se tornasse por completo numa monarquia. Destacaram para liderar a oposição Tucídides de Alópece, um homem sensato e parente de Címon, que, embora fosse menos dotado para a guerra do que Címon, era melhor orador e político. Este manteve-se vigilante na cidade, competiu com Péricles na tribuna e rapidamente criou um equilíbrio de forças políticas. 2. Não deixou que a chamada "nata da sociedade" se dispersasse e se misturasse com o povo, como antes, o que fazia com que a sua dignidade fosse ofuscada pela massificação; tratou de marcar as diferenças e de os reunir todos num corpo coeso, de modo a pôr um contrapeso no prato da balança.

3. É que desde o princípio, subjacente aos factos, havia, tal como no ferro, uma fenda que marcava a divergência entre a preferência democrática e a aristocrática; mas a rivalidade e a ambição destes dois tornou a clivagem da cidade mais profunda e fez com que a uma facção se chamasse povo e a outra, oligarcas.

4. Foi nestas circunstâncias que Péricles afrouxou as rédeas ao povo mais do que em qualquer outra ocasiáo

${ }^{71}$ Referência à época em que Péricles conseguiu o ostracismo de Címon. 
e tomou medidas políticas para lhe agradar, imaginando constantemente na cidade um espectáculo para todos ou um banquete ou uma procissão, e procurando diverti-la com prazeres não estranhos às musas. Enviava anualmente para fora sessenta trirremes em que embarcavam muitos cidadáos assalariados durante oito meses, que ao mesmo tempo praticavam e aprendiam a arte naval. 5. Além disso, enviou mil clerucos para o Quersoneso ${ }^{72}$, quinhentos para $\operatorname{Naxos}^{73}$, metade deste número para Andros ${ }^{74}$; mil para a Trácia com o intuito de fundarem uma colónia com os Bisaltas ${ }^{75}$; outros para a Itália na altura do restabelecimento de Síbaris ${ }^{76}$, à qual chamaram Túrios. 6. Tomou estas medidas para aliviar a cidade de uma multidão inactiva que, por causa da

${ }^{72} \mathrm{O}$ Quersoneso da Trácia, além de possuir um solo muito fértil, era um território estratégico, porque se situava na passagem da Europa para a Ásia, pelo que o seu domínio permitia controlar a afluência dos cereais vindos do Mar Negro para Atenas. No séc. VI a.C., foi propriedade da família de Milcíades; no princípio do séc. $\mathrm{V}$ a. C., a regiáo ficou sob o domínio persa até que por volta de 450 os Atenienses a integraram na Simaquia de Delos e aí fundaram várias cleruquias.

73 Trata-se da ilha mais rica das Cíclades, famosa pelos seus vinhos, que foi um dos primeiros membros da Simaquia de Delos e também a primeira a revoltar-se em 460 a.C. Mas, apesar da tentativa de secessão, foi forçada a permanecer como tributária e passou a cleruquia por volta de 450 a.C.

${ }^{74}$ Ilha mais setentrional das Cíclades e provavelmente também um dos primeiros membros da Simaquia de Delos. Este é o único texto que faz referência a esta cleruquia.

${ }^{75}$ Povo trácio que habitava a Oeste do rio Estrímon.

${ }^{76}$ Antiga cidade da Magna Grécia que ficou conhecida pela sua riqueza e que foi destruída por Crotona em 510 a.C. Em 452 a.C., alguns cidadãos tentaram reconstruí-la, sem grande sucesso, pois foram expulsos. Só em 443 a.C., sob a liderança dos Atenienses, é que, com a nova designaçáo de Túrios, a cidade voltou a existir. 
ociosidade ${ }^{77}$, se intrometia nas reformas políticas, e para atenuar as dificuldades do povo $^{78}$; ao mesmo tempo que instalava junto aos aliados medo e vigilância para que não se revoltassem.

12. 1. O que trouxe encanto e beleza perfeitos a Atenas e originou a maior admiração junto dos outros povos - e que é o único testemunho a favor da Grécia, de que o seu tão celebrado poder e antiga prosperidade não são falácia -, foi a construção dos monumentos. De todas as medidas políticas de Péricles ${ }^{79}$ foi esta a que os inimigos mais criticaram e atacaram na assembleia. Gritavam aos sete ventos que o povo perdia a reputação e era mal falado, porque transferira de Delos para o seu próprio terreno o tesouro comum dos Gregos ${ }^{80}$; e que a justificação mais verosímil que podia contrapor aos que o acusavam era que, temendo os bárbaros, tirara o tesouro dali para o guardar num local seguro - desculpa que Péricles deitou por terra. 2. E a Grécia considera-

77 Com esta afirmação, Plutarco defende Péricles da acusação que alguns, nomeadamente Platão (Górgias 515e), lhe faziam de ser o responsável pela ociosidade do povo.

${ }^{78}$ As razôes até agora apontadas correspondem ao conteúdo do decreto de fundação de Breia (Meiggs-Lewis 1969: 128-129, decreto n. ${ }^{\circ}$ 49), segundo o qual sáo propostos como colonos os tetas e os zeugitas, as classes censitárias mais baixas de Atenas.

${ }^{79}$ Foi Isócrates (15.234) que atribuiu as construçóes do século $\mathrm{V}$ a.C. à responsabilidade individual de Péricles, que interpreta como manifestaçáo da vontade imperialista de Atenas (7. 66).

${ }^{80}$ Refere-se à transferência do tesouro da Simaquia de Delos, inicialmente depositado na ilha que dá nome à coligação, para Atenas por volta do ano 453 a.C., sob o pretexto de que em Delos estaria mais exposto a um hipotético saque bárbaro. Sobre este assunto, vide PritchetT (1969: 17-21). 
-se vítima de uma terrível violência e de uma tirania manifesta, ao ver-nos, com o contributo a que se viu forçada para as necessidades bélicas, recobrir de ouro e embelezar a cidade, como a uma mulher vaidosa, que se cobre de pedras preciosas e de estátuas e templos que valem mil talentos ${ }^{81}$.

3. Por seu lado, Péricles explicava ao povo que não devia satisfaçóes dos fundos aos aliados, pois combatia por eles e mantinha os bárbaros afastados, sem que aqueles contribuíssem com um só cavalo, barco, ou hoplita $^{82}$ que fosse, mas apenas com dinheiro. E esse não pertence aos que o dão, mas aos que o recebem, se cumprem aquilo por que o recebem. 4. Se a cidade já está convenientemente apetrechada com o que é necessário para a guerra, é preciso aplicar os excedentes nestas obras, que, uma vez concluídas, lhe trarão fama eterna, e, enquanto decorrem, ocasionam prosperidade imediata: é que vão proporcionar todo o tipo de trabalho e necessidades diversas, que, ao incitar as várias artes e ao pôr em movimento todas as mãos, darão emprego à

81 Os "adornos" a que o texto faz referência têm um correspondente nas obras da cidade: as "pedras preciosas" dizem respeito ao mármore utilizado na construção dos monumentos; as "estátuas", entre outras, aludem certamente à de Atena Parthenos; os "templos de mil talentos" são uma menção, ainda que hiperbólica, aos custos da construçáo dos templos. Isócrates (7. 66), por exemplo, estimava que se tivesse dispendido uma soma de cerca de mil talentos para construí-los. Mas a quantia exacta foi sempre alvo de polémica: Heliodoro (FGrHist 373 F 1) diz que os Propileus custaram dois mil e doze talentos; Diodoro Sículo (12. 40. 2), por sua vez, fala em quatro mil.

${ }^{82}$ STADTER (1989: 155) afirma que se trata de um argumento falso, já que, por exemplo, em 450 a.C., os aliados auxiliaram Atenas com barcos em Egina e no Egipto e por terra em Tânagra. 
cidade quase inteira, que se auto-embeleza ao mesmo tempo que se alimenta com os próprios recursos.

5. Com efeito, aos que tinham juventude e vigor, as expediçóes proviam de recursos oriundos do tesouro público; quanto à desorganizada multidão operária, Péricles desejava que não fosse excluída do pagamento, e muito menos que fosse paga pelo ócio e inactividade. Por isso, propôs entusiasticamente ao povo grandes projectos de construçóes e planos de obras que implicavam muitas artes e muito tempo de execução, para que a população que ficava em casa náo tivesse menos oportunidade de beneficiar e receber a sua parte do tesouro público do que as tripulaçóes que navegavam, as guarniçôes e os militares.

6. As matérias-primas eram pedra, bronze, marfim, ouro, ébano e cipreste; os ofícios para as trabalharem e elaborarem eram os dos carpinteiros, fabricantes de moldes, forjadores, pedreiros, douradores, artistas do ouro e do marfim ${ }^{83}$, pintores, cravejadores, cinzeladores; já para não falar dos transportadores e fornecedores: por $\mathrm{mar}^{84}$, os comerciantes, marinheiros e pilotos; por terra, os carreteiros, os donos de juntas, os cocheiros; e ainda os cordoeiros, os tecelães, os curtidores, os empreiteiros de estradas, os mineiros. Cada ofício, como um general o seu exército particular, tinha uma multidão organizada de trabalhadores náo especializados, como um instrumento

${ }^{83}$ Sobre o trabalho do marfim, que requer um tratamento para torná-lo manuseável, nos fala Plutarco em Obras Morais 499e.

${ }^{84} \mathrm{O}$ bronze, o marfim, o ouro, o ébano e os ciprestes chegavam a Atenas por mar, porque eram materiais que não existiam na Ática. 
e corpo de serviço ${ }^{85}$. Assim, as necessidades repartiram e distribuíram o bem-estar pelas pessoas a bem dizer de todas as idades e condiçóes.

13. 1. Os edifícios erguiam-se imponentes de proporçôes e detentores de uma beleza e graça inimitáveis, pois os artistas esforçavam-se por superar a prática da sua arte com a perfeição técnica; mas o mais admirável foi a rapidez da execução. 2. É que se previa que cada uma dessas obras levaria várias geraçóes a ser concluída, mas todas chegaram ao fim durante o apogeu de um único governo.

3. Diz-se, no entanto, que uma vez Zêuxis ${ }^{86}$, ao ouvir o pintor Agatarco ${ }^{87}$ vangloriar-se alto e bom som da rapidez e facilidade com que pintava as figuras, replicou: 4. "Pois eu levo muito tempo". É que a destreza e a rapidez na execução não conferem à obra solidez estável, nem beleza perfeita; porém o tempo aplicado de antemão na fadiga da execução dá em troca

85 Segundo Ferguson (1904: 5-20), é possível que, para esta comparaçáo, Plutarco tivesse em mente a medida de Adriano, e que ordenou a organização de certos ofícios quais cohortes, como se de legióes militares se tratasse (cf. S. Aurélio Victor, Epitome de César 14. 5).

${ }^{86}$ Pintor de Heracleia, no sul da Itália, que iniciou a sua actividade em 435 a.C. Mais novo do que Agatarco, ficou conhecido pela subtileza das sombras que fazia. Há uma anedota que ilustra bem o realismo das suas obras: umas uvas pintadas, provavelmente num cenário para um drama satírico, chegaram a ser debicadas pelos pássaros. Sobre este e os outros artistas referidos neste capítulo, veja-se WoOdFord (1982).

${ }^{87}$ Pintor de Samos que viveu no séc. V a.C. Segundo Plutarco (Obras Morais 346a), terá sido o inventor da perspectiva, do sombreado e do uso de cores mistas em vez de puras. 
a durabilidade na preservação do que foi criado. Daí que as obras de Péricles sejam mais dignas de admiração, já que foram produzidas em pouco tempo, para durarem muito.

5. No que respeita à beleza, cada obra se mostrou desde logo venerável; quanto ao esplendor, está ainda agora fresco, como se tivesse sido acabada de fazer. Deste modo, nelas floresce continuamente uma certa juventude, que conserva um aspecto incorruptível pelo tempo, como se as obras incorporassem um espírito sempre jovem e uma alma que não envelhece.

6. Fídias ocupou-se de tudo e de tudo foi o supervisor ${ }^{88}$, embora as obras tivessem grandes arquitectos e artífices. 7. Calícrates ${ }^{89}$ e Ictino ${ }^{90}$ fizeram

${ }^{88}$ É apenas neste passo e em Per. 13. 14 que se atribui a Fídias um papel táo importante no projecto de embelezamento da cidade. No entanto, não é possível identificar as fontes que Plutarco utiliza para fazer tal afirmação. Parece, porém, pouco provável que este escultor tenha sido tão influente. Este passo é certamente hiperbólico e provavelmente consequência da famosa história segundo a qual Péricles e Fídias eram amigos íntimos (vide Per. 31. 1).

${ }^{89}$ Este arquitecto do século $\mathrm{V}$ a.C. trabalhou na construção das muralhas e fez o projecto do templo de Atena Nike, em estilo iónico. Também lhe é atribuído o terceiro templo de Apolo em Delfos.

${ }^{90}$ Segundo Estrabão (9. 395) e Pausânias (8. 41. 9), foi o único arquitecto do Pártenon. Parece que chegou a escrever um livro sobre esta obra, onde explicava os princípios utilizados na sua construçáo. Estrabáo (9.395) afirma que Ictino foi também o autor do telestério de Elêusis, embora Plutarco, seguindo fonte desconhecida, atribua a sua construçáo a Corebo e Metágenes apenas. De acordo com Pausânias (8. 41. 9), foi também o responsável pelo templo de Apolo em Figália. Terá sido o primeiro arquitecto a introduzir elementos iónicos na ordem dórica. 
o Pártenon hecatômpedo ${ }^{91}$; em Elêusis ${ }^{92}$, Corebo começou a construir o telestério - implantou as colunas no pavimento e uniu-as às arquitraves; depois da sua morte, Metágenes de Xípeto ${ }^{93}$ acrescentou os frisos e as colunas superiores; Xénocles de Colarges ${ }^{94}$ concluiu a clarabóia sobre o santuário. A grande muralha, sobre a qual Sócrates diz ter ouvido pessoalmente Péricles propor o projecto, foi Calícrates que a construiu ${ }^{95} .8$. Cratino parodia essa obra pela lentidáo com que foi executada (fr. 326 K.-A.): "Há tempos infinitos que Péricles, em palavras, é um vê se te avias, mas em obras nem se mexe." 96

91 "De cem pés". Consta que o Pártenon, templo de Atena Parthenos, divindade que protegia a cidade, foi construído entre 447-432 a.C. no local anteriormente ocupado por um templo rectangular de cem pés áticos $(29,57 \mathrm{~m}$.). Para mais informações sobre este edifício, leia-se Dinsmoor (1950: 159-179).

${ }^{92}$ Elêusis era uma cidade da Ática situada entre Atenas e Corinto, onde se celebrava o culto de mistérios mais famoso da Grécia: os mistérios de Elêusis, dedicados a Deméter e Perséfone. Este culto decorria a expensas da pólis e a sala dos mistérios - telestério foi alargada e reconstruída por várias vezes: no séc. VI a.C., por Pisístrato; nos princípios do séc. V a.C. (antes de 480 a.C.) e anos mais tarde por Péricles.

${ }^{93}$ Metágenes apenas é mencionado por Plutarco. Pertencia a uma trítia urbana e à tribo Cecrópida.

${ }^{94}$ Apenas é referido por Plutarco.

${ }^{95}$ Esta é a única obra de Péricles que Platão menciona (Górgias 455e). Trata-se do muro central (cf. Plutarco, Obras Morais 351a) que unia directamente o Pireu a Atenas e que era paralelo ao muro que ficava mais a norte e que fora construído entre 445-443 a.C.

${ }^{96}$ A decisão de construir o muro data da primavera de 445 a.C., mas o seu projecto é provavelmente anterior. Para a lentidão dos trabalhos contribuíram a crise em Atenas no ano de 446 a.C., as exigências da guerra com Mégara e Eubeia e uma invasão dos Lacedemónios à Âtica. 
9. O Odeão ${ }^{97}$, que tinha, no interior, muitos assentos e muitas colunas e cujo tecto era inclinado de todos os lados partindo de um único vértice, dizem que foi feito à imagem e semelhança da tenda do Rei Persa, e a sua construção foi presidida por Péricles. 10. Por isso, Cratino, em Trácias, troça dele mais uma vez (fr. 73 K.-A.): "Aí vem o Zeus-Péricles cabeça de cebola com o Odeão enterrado na tola, agora que a história do caco foi à viola." 98

11. Por ambição política, Péricles decretou ${ }^{99}$ então pela primeira vez que houvesse um concurso de música nas Panateneias ${ }^{100}$ e ele próprio, designado

${ }^{97}$ Sala de música situada na vertente sul da Acrópole e a este do teatro de Dioniso. Este edifício tinha 62,4 m x 68,6 m e era constituído por dez filas de nove colunas. Segundo Pausânias (1. 20. 4), foi incendiado por Sila quando este invadiu Atenas. Consequentemente, Plutarco conheceu uma reconstrução posterior. A reproduçáo do edifício pode ver-se em Izenour (1992: 34-35).

$98 \mathrm{O}$ ostrakon era o caco onde se fazia a votação do ostracismo, medida instituída possivelmente por Clístenes para punir aqueles que de algum modo agissem contra a polis. Anualmente, na reunião da Assembleia, cada membro escrevia num "caco" o nome do indivíduo que entendesse dever ser afastado. $\mathrm{O}$ nome que reunisse mais votos era exilado por dez anos. Este era um meio a que, até 443 a.C., frequentemente se recorria para tentar afastar inimigos políticos. Ao que parece, Péricles terá usado este estratagema, nomeadamente para afastar Tucídides, filho de Melésias (Per. 14. 3).

99 Tal decreto deve ser anterior a 446 a.C., data provável da conclusão dos trabalhos do Odeão.

${ }^{100}$ As Panateneias eram um festival que se celebrava anualmente a 28 de Hecatombéon (Julho-Agosto) desde os tempos de Pisístrato para comemorar o nascimento de Atena. De quatro em quatro anos, porém, eram celebradas com especial solenidade, dando origem às Grandes Panateneias. Nestas eram de especial importância a procissão, as competiçóes de ginástica, as corridas de cavalos, os 
presidente do júri, dispôs como convinha que os concorrentes tocassem flauta, cantassem, ou tangessem cítara. Assistiu-se, então, como em outros momentos, a concursos de música no Odeão.

12. Os Propileus ${ }^{101}$ da Acrópole, construídos pelo arquitecto Mnésicles, foram concluídos num quinquénio. Um acontecimento fantástico, que teve lugar durante a sua construção, revelou que a deusa Atena não lhe era indiferente, mas até ajudava a construir e concluir a obra. 13. $\mathrm{O}$ mais activo e zeloso dos artífices escorregou e caiu do cimo do edifício ${ }^{102}$; ficou num estado de tal maneira lamentável, que foi desenganado pelos médicos. Péricles estava desanimado, mas a deusa apareceu-lhe em sonhos

concursos de música e as recitaçóes dos Poemas Homéricos. Sobre este assunto, vide Parke (1977: 33-50); Rocha Pereira ( $\left.{ }^{8} 1998\right)$.

$\mathrm{O}$ primeiro vencedor musical que se conhece é Frinis, que segundo Aristófanes (escólio a Nuvens 969), obteve a vitória em 446 a.C. No entanto, há vestígios arqueológicos que evidenciam a existência de competiçóes musicais nas Panateneias desde o séc. VI a.C., que provavelmente terão sido interrompidas e mais tarde retomadas por Péricles quando construiu o Odeão. Vide DAvison (1958: 23-42).

101 Porta monumental da Acrópole que foi construída entre 437-6 e 433-2 a.C.: são estes os dois monumentos mais famosos edificados sob o domínio de Péricles. Os Propileus foram construídos em mármore pentélico e seguem o estilo iónico no interior, mas o dórico no exterior. Para mais pormenores sobre este monumento, leia-se Dinsmoor (1950: 199-205).

${ }^{102}$ Plínio (História Natural 22.43-44) refere-se ao indivíduo em questão, dizendo que era um escravo muito estimado por Péricles que teria caído do cimo de um templo. Segundo Plutarco, o artífice teria sofrido o acidente enquanto trabalhava nos Propileus. O certo é que chegaram até nós numerosas variaçóes sobre o sucedido (uma, por exemplo, conta que o escravo teria caído do cimo de uma oliveira), o que mostra que esta anedota se transformou num topos retórico, como sugere PÉrez Jiménez (1996: 449). 
e indicou-lhe um remédio ${ }^{103}$, com o qual Péricles tratou e curou o homem com toda a rapidez e facilidade. Por isso, erigiu uma estátua em bronze de Atena Higia $^{104}$ na Acrópole, junto do altar da deusa que, segundo dizem, já existia antes.

14. Foi Fídias quem executou a estátua de ouro da deusa ${ }^{105}$ e, como seu autor, tem o nome inscrito na estela. Quase todos os trabalhos estavam sob a sua orientação e, como disse, superintendia a todos os artistas por causa da amizade com Péricles. 15. Tal facto valeu invejas a um e calúnias ao outro, pois constava que Fídias arranjava, para Péricles, encontros com mulheres livres que vinham de visita às obras. Os cómicos deitaram mão à história e espalharam muita sem-vergonhice a seu respeito, com insinuaçóes contra a mulher de Menipo, seu amigo e subalterno ${ }^{106}$, e contra a criação de aves de Pirilampes ${ }^{107}$, também amigo de Péricles, que era

103 Segundo Plínio (História Natural 22. 43-44), tratava-se da herba urceolaris ou astercum.

${ }^{104}$ Epíteto que Atena recebia enquanto protectora da saúde (cf. Pausânias 1. 23. 4).

${ }^{105}$ A estátua em questão, com cerca de dez metros de altura, era constituída por uma estrutura de madeira abundantemente recoberta de ouro (no que respeita à figuração das roupas) e de marfim (no rosto, nas armas e nos pés) - daí ser chamada de criselefantina.

${ }^{106}$ Menipo apenas é referido em Obras Morais 812c, onde se diz que foi um colaborador militar de Péricles.

107 Filho de Antifonte, casou-se em segundas núpcias com a mãe de Platão que era sua sobrinha (cf. Platão, Cármides 158a, Parménides 126b). Foi como embaixador à Ásia Menor e à Pérsia, de onde trouxe, em 440 a.C., pavóes reais oferecidos pelo Rei. Estes animais exóticos foram durante cerca de trinta anos atracção em Atenas (STADTER 1989: 179). 
acusado de se servir dos pavôes para subornar as mulheres com quem Péricles andava metido. 16. E porque há-de alguém surpreender-se de que homens que levam uma vida libertina sacrifiquem constantemente à inveja geral, como a uma divindade malfazeja, calúnias contra quem lhes é superior, quando até Estesímbroto de Tasos se atreveu a publicitar, contra Péricles, um sacrilégio terrível e repugnante com a mulher do próprio filho ${ }^{108}$ ?

Assim parece ser penoso e difícil a quem investiga encontrar a verdade: os que vêm depois têm o tempo entretanto decorrido a obscurecer o conhecimento dos factos; por seu lado a contemporaneidade com os acontecimentos e com as vidas corrompe e distorce a verdade ora por invejas e hostilidades, ora por favores e adulaçóes.

14. 1. Quando os oradores apoiantes de Tucídides clamavam contra Péricles, acusando-o de delapidar o dinheiro e de desperdiçar os lucros, este perguntou ao povo na assembleia se lhe parecia que gastava muito. Como the responderam que gastava muitíssimo, retorquiu: "Pois bem, imputem-me a mim as despesas e não mais a vocês!... mas apenas o meu nome constará das dedicatórias dos monumentos.” 2. Ora quando Péricles fez esta afirmação, ou por admirarem a sua grandeza de alma, ou por rivalizarem pela glória dos edifícios, foi aos gritos que o exortaram a gastar do erário público e a usá-lo sem olhar a poupanças.

3. Por fim, ousou fazer frente a Tucídides e arriscar

${ }^{108}$ Vide Per. 36. 6. 
uma campanha pelo ostracismo, que lhe permitiu expulsá-lo e derrubar a facção oposta ${ }^{109}$.

15. 1. Foi então, quando esta divergência ficou inteiramente resolvida e a cidade se tornou homogénea e bem unida, que chamou a si Atenas e os assuntos que dependiam dos Atenienses: tributos, tropas, trirremes, ilhas, mar, o potencial de que dispunha entre Helenos e Bárbaros e a hegemonia, garantida pela obediência dos povos, pelas alianças com reis e pelos acordos com dinastas. Ele próprio já não era o mesmo na tolerância para com o povo, nem na complacência para se submeter ou ceder aos desejos da multidáo, que eram como o vento. Por oposição àquela demagogia transigente e por vezes branda, qual melodia florida e delicada, tangeu as cordas de um governo aristocrático e régio que usou com as melhores intençóes de modo justo e inflexível. $\mathrm{Na}$ maior parte das vezes, conduziu, pela persuasão e com sentido pedagógico, o povo que o seguia de bom grado. Mas, quando o via muito descontente, retesava-lhe os freios e obrigava-o a agir de acordo com o que era do interesse público. Parecia realmente um médico ${ }^{110}$

109 De um modo geral, aponta-se como data do ostracismo de Tucídides, filho de Melésias, o ano de 443 a.C., pois em Per. 16. 3, Plutarco afirma que a supremacia de Péricles se prolongou por quinze anos após este acontecimento. No entanto, esta data não é aceite sem controvérsia: se admitirmos que o último ano de Péricles no poder é o da sua deposição (Outono de 430 a.C.), então o ostracismo de Tucídides foi votado no início de 444 a.C.; se considerarmos que Péricles só abandona o poder com a morte (novamente reeleito estratego na Primavera de 429 a.C.) a data é, de facto, 443 a.C.

110 Também Platão (Fedro 270b-d) comparou o verdadeiro 
que, perante uma doença complicada e longa, conforme a ocasiáo, consente prazeres inofensivos, ou prescreve remédios cáusticos que trazem a cura.

2. Como é natural, paixóes de todos os tipos nasceram numa multidão com tamanho poder; Péricles era o único capaz de controlar convenientemente cada uma, utilizando sobretudo esperanças e medos, como um leme, para dominar a arrogância dos Atenienses ou para animar e consolar o seu desalento. Mostrou que a eloquência é, como diz Platáo ${ }^{111}$, a arte de conduzir o espírito e que o seu principal papel é dar acesso aos sentimentos e às paixóes, que são as cordas e sons da alma e que pedem um dedilhar hábil e harmonioso. 3 . A causa do sucesso que granjeou náo foi somente a força do discurso, mas, como diz Tucídides ${ }^{112}$, a reputação da sua vida e o crédito de que gozava, como alguém manifestamente incorruptível e inacessível a subornos. Assim, fez da cidade que recebeu forte, a mais forte e a mais rica, e ele próprio, no que respeita ao poder, ultrapassou muitos reis e tiranos. Várias de entre essas personalidades o designaram até como tutor dos seus fihos. Mas não acrescentou uma única dracma ao património que o pai lhe deixara.

orador a um médico. Segundo o fundador da Academia (República 425a-426b), ambos recorrem a pharmaka, kauseis e tomai. Sobre o uso que Plutarco faz da imagética médica quando se refere ao homem de Estado, leia-se Fuhrmann (1964: 238-240).

${ }^{111}$ Fedro 271 c-d.

${ }^{112}$ Tucídides 2. 65. 8. 
16. 1. Todavia, quanto ao poder que detinha, Tucídides descreve-o com clareza ${ }^{113}$, e mesmo os cómicos (adesp. 703 K.-A.), com os seus azedumes, o deixam patente, quando chamam aos seus correligionários a nova geração dos Pisistrátidas; exortam-no, por outro lado, a jurar que não se irá transformar num tirano, como se fosse desmesurada e opressiva para o sistema democrático a sua supremacia.

2. Teleclides diz que os Atenienses lhe confiaram (fr. 45 K.-A.) "as taxas das cidades e as próprias cidades, umas para serem subjugadas, outras libertadas; as muralhas de pedra, umas para construir, outras, pelo contrário, para deitar de novo abaixo, as alianças, a força, o poder, a paz, a riqueza e a felicidade".

3. E esta situação não foi resultado de uma conjuntura, de um momento de auge ou da popularidade de um governo que floria na sua estação, pois, durante quarenta $\operatorname{anos}^{114}$, Péricles manteve a primazia entre homens como Efialtes, Leócrates ${ }^{115}$, Mirónides ${ }^{116}$,

113 Vide Per. 9. 1.

114 Este número é tradicional e surge também em Cícero, Do Orador 3. 138. Assim, Péricles teria ascendido ao poder por volta de 468 a.C., tendo em conta que a sua morte ocorreu em 429 a.C. Mas os estudiosos modernos, de um modo geral, não o aceitam, pois acreditam que Péricles apenas se tornou proeminente após a morte de Efialtes, em 461 a.C., um ano após a reforma do Areópago. Sobre a posição dos modernos, veja-se MeInHARdT (1957: 46, n. 132).

${ }^{115}$ Filho de Estrebo, foi estratego ateniense entre 479-478 a.C. em Plateias e, em 459-458 a.C., ocupando o mesmo cargo, sitiou Egina (Tucídides 1. 105. 2).

116 Também foi estratego em Plateias e membro de uma embaixada a Esparta, enviada por Aristides em 480-479 a.C., na qual participaram ainda Címon e Xantipo (Heródoto, Histórias 9. 
Címon, Tólmides ${ }^{117}$ e Tucídides [o filho de Melésias]. E depois da derrota e do ostracismo de Tucídides, durante não menos de quinze anos $^{118}$, manteve um poder único e contínuo que lhe advinha do cargo anual de estratego ${ }^{119}$. Conservou-se impermeável ao dinheiro, embora não

6. 11; Plutarco, Aristides 10. 10). Venceu, como estratego, em 458 a.C., os Coríntios em Mégara; em 456 a.C., os Tebanos em Enófita; dois anos mais tarde, comandou uma expedição à Tessália.

${ }^{117}$ Democrata radical que ficou conhecido pela expedição naval à volta do Peloponeso em 456/455 a.C., quando incendiou os estaleiros espartanos em Gítio. Conquistou as cidades de Cefalénia, Naupacto e Cálcis, no Golfo de Corinto, e saqueou as terras de Sícion (Tucídides 1. 108. 5). Liderou cleruquias em Eubeia e Naxos e morreu em Coroneia como comandante das tropas enviadas em 447 a.C. para pôr fim às sublevaçôes na Beócia.

${ }^{118}$ Estes anos incluem-se, obviamente, nos hipotéticos quarenta em que Péricles esteve no poder, com ou sem oposição. Caso contrário, isto é, se a estes quinze anos somássemos os quarenta, Péricles teria sido figura activa nas Guerras Pérsicas, o que é impensável se tivermos em conta que ele nasceu em 492 a.C.

119 Os estrategos constituíam um colégio de dez membros oriundos da classe censitária mais elevada (pentacosiomedimnos). Não eram sorteados como a maioria dos magistrados, mas eleitos anualmente (à razão de um por tribo) pela Assembleia, que lhes indicava as directrizes a seguir e à qual tinham de prestar contas. Os membros desta magistratura - que nos séculos V e IV a.C. foi uma das principais do regime democrático - podiam ser reeleitos sem limite de mandatos, como aconteceu com Péricles durante quinze anos consecutivos. Além do poder militar, que era o que originalmente possuíam, tinham também autoridade política e administrativa, pelo que necessitavam de ser bons oradores para convencerem a Assembleia das suas opçôes políticas. A partir do início da Guerra do Peloponeso, porque ficavam muito tempo no campo de batalha e afastados da tribuna, vão-se assumindo cada vez mais como técnicos militares desligados da política e passam a ser eleitos, já não um por tribo, mas indiferentemente dentre todos os cidadãos. Para mais pormenores sobre esta magistratura, leiam-se, por exemplo, Ribeiro Ferreira (1990: 112-113); Mossé (1992: 457-459). 
fosse totalmente indiferente a questóes de negócios. Assim, para que, por descuido, o património paterno e legítimo não se esvaísse, e para que não trouxesse ainda mais afazeres e preocupaçóes a quem já estava muito ocupado, organizou uma forma de administração que pensava ser a mais fácil e exacta. 4 . Vendia por junto toda a colheita anual e depois comprava na ágora cada produto à medida que era necessário ao seu dia-a-dia e regime de vida. 5. Por isso não agradava aos filhos quando adultos, nem era um administrador generoso para as mulheres deles: criticavam-lhe essa gestão limitada ao dia-a-dia e sujeita a restriçôes, onde não havia as superfluidades habituais numa casa grande e rica, e qualquer despesa ou lucro se contrabalançavam com peso e medida. 6 . Quem lhe controlava toda esta disciplina era o criado Evângelo, que ou era dotado, como nenhum outro, de capacidades inatas para a administração, ou tinha sido instruído por Péricles para o efeito. 7. Esta conduta estava em desacordo com a doutrina de Anaxágoras, se é realmente verdade que aquele deixou a casa e abandonou os campos que possuía incultos para pasto das ovelhas, por inspiração divina e por grandeza de alma ${ }^{120}$. Mas

${ }^{120}$ Anaxágoras era oriundo de família rica e influente. No entanto, teria abdicado da sua herança e das facilidades e sucesso político, que poderia alcançar se daquela dispusesse, para se entregar à ciência e à filosofia (cf. Platão, Hípias Maior 281c, 283a; Diógenes Laércio 2. 6-7). Para ele a vida só tinha valor se servisse para uma melhor compreensáo do cosmos a que se pertence; tudo o resto é supérfluo: o apego aos bens materiais e à felicidade terrena náo vale a pena, pois todo o homem é mortal $\mathrm{e}$, mais cedo ou mais tarde, todos têm o mesmo destino (vide GuThrie 1969: 266 sq.). Péricles, embora admirasse Anaxágoras como ninguém (Per. 5. 1), tinha uma visão mais pragmática da vida e nisso não seguia os 
penso que a vida de um filósofo contemplativo e a de um político não são a mesma coisa: o primeiro estimula a inteligência para o Bem sem precisão de instrumentos ou materiais externos; porém, para o político que mistura a excelência com as carências humanas, há circunstâncias em que a riqueza não só é uma necessidade, mas mesmo uma virtude, como era o caso de Péricles que socorria muitos pobres ${ }^{121}$. 8. Na verdade, contam que o próprio Anaxágoras, já velho, sentindo-se abandonado por Péricles, que estava sempre ocupado, se deitou e cobriu para morrer de fome. Quando o sucedido chegou aos ouvidos de Péricles, este, aturdido, foi logo a correr para junto do amigo e dirigiu-lhe todo o tipo de súplicas, e náo era por aquele que se lamentava, mas por si próprio, se perdesse tal conselheiro dos assuntos de Estado. 9. Anaxágoras descobriu-se e disse-lhe: "Péricles, também os que necessitam de uma lâmpada lhe deitam azeite."

\section{1. Quando os Lacedemónios começaram} a ficar incomodados com a ascensão dos Atenienses, Péricles, para exaltar o povo a orgulhar-se ainda mais e a julgar-se digno de grandes empresas, promulgou um decreto $^{122}$, determinando que todos os Gregos, habitantes

ensinamentos do seu mestre, como no-lo diz Plutarco neste passo.

${ }^{121}$ É costume de Plutarco atribuir a virtude da caridade às suas personagens (cf. Sólon. 2. 1), bem como reflectir sobre o uso que um político deve fazer do dinheiro (cf. Publícola 1. 2, Fab. 7. 7, 8, Per.-Fab. 30.5). Mas náo consta que Péricles fosse possuidor de uma generosidade desinteressada, no que contrasta com Cimon (10) e Nícias (3. 1).

${ }^{122}$ Este é o único testemunho deste decreto de Péricles, de autenticidade, data e natureza controversas. A indicaçáo temporal 
de qualquer parte da Europa ou da Ásia, de uma cidade pequena ou grande ${ }^{123}$, enviassem embaixadores a Atenas para uma reuniáo: para falarem sobre os templos gregos $^{124}$ que os bárbaros tinham incendiado; sobre os sacrifícios que os Gregos prometeram, quando lutaram contra os bárbaros, e que ainda devem aos deuses; e também sobre o mar, para que todos naveguem em segurança e mantenham a $\mathrm{paz}^{125}$.

2. Para o efeito, foram enviados vinte homens com mais de cinquenta anos ${ }^{126}$, dos quais cinco para convidar

que Plutarco avança é muito vaga - "Quando os Lacedemónios começaram a ficar incomodados com o ascensão dos Atenienses" -, o que sugere que também ele não deve ter tido acesso a informação mais precisa ou, pelo menos, náo sentiu necessidade de fornecer esse elemento. Assim, de acordo com o que o Queroneu nos diz, este decreto pode datar de qualquer altura entre 460 a.C. e o início da Guerra do Peloponeso. Tendo em conta que náo faria sentido debater a destruição dos templos levada a cabo pelos Persas após a reconstruçáo do Pártenon (447 a.C.), podemos indicar essa data como terminus ante quem. Para terminus post quem, é possível sugerir que coincida com o período da Paz de Cálias, o que faz com que a data oscile entre 460 e 449 a.C. Sobre este decreto, vide MaCDONALD (1982: 120-123).

${ }^{123}$ Excluindo os Gregos da Itália e da Sicília.

${ }^{124}$ Além dos templos de Atenas, também foram incendiados os da Fócida, de Téspias e Plateias (Heródoto, Histórias 8. 32-33, 50, 53).

${ }^{125}$ Aceita-se de um modo geral que esta menção diga respeito à Paz de Cálias. No entanto, pode perfeitamente ser uma referência a outro tratado, nomeadamente o de cinco anos datado de 451 a.C. (Tucídides 1. 112. 1).

${ }^{126}$ Os decretos atenienses que se conservam fixam a idade de cinquenta anos como mínima para que se possa desempenhar o cargo de embaixador (vide Todn 1948: inscr. 61. 1. 17 sq.). Este decreto náo foi citado por nenhum outro autor cujos textos chegaram até nós, pelo que esta referência de Plutarco tem dado azo a diversas discussóes sobre a sua data e veracidade. A frase em 
os Iónios, os Dórios da Ásia, e os ilhéus até Lesbos e Rodes; cinco percorreram locais do Helesponto e da Trácia até Bizâncio; outros cinco foram para a Beócia, para a Fócida e para o Peloponeso e daí se afastaram, através da Lócrida, para o território vizinho até à Acarnânia eà Ambrácia. 3. Os restantes foram por Eubeia para Eta, para o golfo Malíaco e para a Ftia, para a Acaia e para a Tessália, exortando-os a irem tomar parte na reunião sobre a paz e as actividades conjuntas da Grécia. 4. Mas nada foi feito nem as cidades se reuniram, porque os Lacedemónios se opuseram secretamente, segundo se diz, já que o projecto foi recusado primeiro no Peloponeso. Se conto este episódio é para mostrar a sua nobreza de espírito e grandeza de alma.

18. 1. Nas questôes militares tem boa reputação sobretudo pela prudência, pois não se aventurava voluntariamente se a guerra oferecesse um risco muito incerto, nem invejava ou imitava os grandes generais que se expunham ao perigo, dele tiravam grandes sucessos e colhiam muita admiração. Dizia muitas vezes aos cidadãos que, no que dependesse dele, permaneceriam para sempre imortais.

2. Ao ver que Tólmides, filho de Tolmeu, graças ao êxito anterior e à honra com que era distinguido

causa e as que se lhe seguem são o maior indício de que se trata de um decreto verídico, pois reflecte o estilo formular dos decretos do séc. V a.C. Além disso, se o considerarmos autêntico, aceitamos, com Plutarco, que se trata de uma importante indicação acerca da política externa de Péricles, que queria ultrapassar a proeminência de Esparta relativamente aos aliados. 
pelos seus feitos militares, se preparava para atacar a Beócia num momento pouco oportuno e persuadira os mais valentes e ambiciosos jovens em idade militar a proporem-se como voluntários para a luta - eram mil além das outras tropas -, tentou impedi-lo e dissuadi-lo na assembleia, proferindo aquela frase que ainda é lembrada: se não acreditava em Péricles, não perdia por dar tempo ao tempo, que é o conselheiro mais avisado. 3. $\mathrm{Na}$ ocasião essa frase foi pouco apreciada, mas alguns dias depois, quando foi anunciado que o próprio Tólmides tinha morrido, vencido numa batalha junto de Coroneia, e que com ele tinham perecido muitos nobres ${ }^{127}$, o facto trouxe a Péricles grande reputação e simpatia como homem prudente e patriota.

19. 1. Das suas expediçôes, a do Quersoneso ${ }^{128}$ foi a mais apreciada, pois trouxe a salvação para os Gregos que ali habitam. Não só fortaleceu as cidades com homens vigorosos ao enviar mil colonos atenienses, mas também cintou o istmo com fortalezas e muralhas de mar a mar, impediu as incursōes dos Trácios espalhados ao redor do Quersoneso e pôs fim a uma guerra contínua e penosa, pela qual a região esteve desde sempre oprimida, em contacto com vizinhos bárbaros e infiltrada de tropas piratas nas fronteiras e no interior. 2. Foi admirado e ficou mesmo célebre entre os

127 Dentre os quais Clínias, o pai de Alcibíades (Plutarco, Alcibiades 1. 1; Platão. Alcibiades 112c; Isócrates 16. 28).

${ }^{128}$ A campanha, que libertou a região do flagelo dos piratas, bem como a cleruquia, deve datar de 447 a.C., segundo parece indicar uma inscriçãoo $\left(I G \mathrm{I}^{2} 943\right)$. 
estrangeiros por ter circum-navegado o Peloponeso ${ }^{129}$, fazendo-se ao mar a partir de Pegas ${ }^{130}$ em Mégara, com cem trirremes ${ }^{131}$. Não só devastou grande parte da costa, como antes Tólmides ${ }^{132}$, mas avançou para o interior com a infantaria que seguia nos barcos. Fez recuar para dentro das muralhas todos os que temiam os seus ataques; em Nemeia ${ }^{133}$, depois de ter posto em fuga, pela força, os Siciónios que lhe ofereceram resistência e com ele combateram, erigiu um monumento comemorativo. 3. Depois de receber da Acaia, que era sua aliada, soldados para as trirremes, avançou com a frota para o continente defronte; costeando o Aqueloo ${ }^{134}$, assolou a Acarnânia e aprisionou os Enéadas dentro das muralhas. E depois de lhes devastar e saquear o território, retornou a casa, mostrando-se terrível aos inimigos, prudente e eficaz aos concidadãos. Nenhum obstáculo, nem mesmo acidental, surpreendeu os seus soldados.

${ }^{129}$ Ao contrário de Tólmides que realmente deu a volta ao Peloponeso, Péricles atravessou o golfo de Corinto, partindo de Pegas e regressando ao mesmo porto. Esta expedição também é mencionada por Tucídides (1. 111. 2-3).

130 Este porto no golfo de Corinto foi uma das principais conquistas dos Atenienses após a aliança com Mégara no princípio da década de 450 a.C. (Tucídides 1. 103. 4), porque dava acesso directo ao golfo. Tal acesso era importante, pois se dele não pudessem usufruir, teriam de dar a volta ao Peloponeso.

${ }^{131}$ Segundo Diodoro Sículo (11. 85. 1), eram apenas cinquenta.

${ }^{132}$ Em 456-455 a.C. segundo Tucídides (1. 108. 5) e Diodoro Sículo (11.84).

${ }^{133}$ Vale no território de Cleonas, onde se situava o santuário de Zeus Nemeu e onde se realizavam os jogos do mesmo nome.

${ }^{134}$ Rio mais largo da Grécia que atravessa o Noroeste da Etólia, fazendo fronteira entre esta região e a Acarnânia, na costa ocidental do continente. 
20. 1. Navegou para o Ponto ${ }^{135}$ com uma grande frota, magnificamente equipada. Aí concedeu às cidades gregas o que pediam e tratou-as com humanidade; perante os povos bárbaros das redondezas e os seus reis e príncipes, exibiu a grandeza do seu poder, a segurança e a audácia com que podiam, se desejassem, navegar e dominar todo o mar. Deixou aos Sinópios ${ }^{136}$ treze naus e uma força de infantaria sob o comando de Lâmaco ${ }^{137}$ para lutar contra o tirano Timesilau ${ }^{138} .2$. Expulso este e os seus partidários, Péricles decretou que seiscentos

${ }^{135}$ Esta expedição, que apenas é mencionada por Plutarco, terá ocorrido entre a Guerra de Samos e a do Peloponeso e, segundo STADTER (1989: 217) terá sido uma tentativa de demonstração de poder da parte de Péricles aquando da ascensão de uma nova dinastia no Bósforo (cf. Diodoro Sículo 12.31. 1).

136 Sinope foi um importante empório do centro da costa meridional do Mar Negro, fundado por Mileto no séc. VII a.C. (Heródoto faz-lhe referência, por exemplo em 2. 34. 2; 4. 12.1). Em 437 a.C., Péricles pôs fim à tirania que aí existia e fundou uma cleruquia.

${ }^{137}$ Trata-se, provavelmente, do filho de Xenófanes e do mesmo indivíduo que, como general, perdeu dez navios em 424 a.C. por ocasião da recolha dos tributos na regiáo do Ponto (Tucídides 4. 75. 1-2). Também participou na expedição à Sicília em 415414 a.C., já com cerca de cinquenta anos e muita experiência militar acumulada. Quando teve lugar a campanha a que Plutarco se refere neste passo, deveria ser co-general com Péricles. Foi ridicularizado por Aristófanes em Acarnenses e Paz pela posição belicista assumida durante a Guerra do Peloponeso, e elogiado pelo mesmo comediógrafo por causa da sua morte heróica em Siracusa (Rãs 1039).

${ }^{138} \mathrm{Na}$ década de 1980, foi encontrada em Ólbia uma inscrição onde figura o nome de Timesilau. Por isso se pensa que o tirano e o seu irmão se refugiaram em Ólbia - cidade na costa do Mar Negro, habitada pelos Olbiopolitai (Heródoto 4. 18) -, depois de terem abandonado Sinope. 
Atenienses voluntários navegassem para Sinope e coabitassem com os Sinópios, partilhando as casas e as terras que o tirano e seus sequazes antes possuíam.

3. Mas noutros aspectos, não cedeu aos impulsos dos cidadáos, nem permitiu que, estimulados pelo poderio e êxito conseguidos, atacassem de novo o Egipto $^{139}$ e perturbassem as zonas costeiras do império persa. 4. Então já a muitos dominava aquela obsessão infeliz e desgraçada da Sicíliaa ${ }^{140}$, que depois Alcibíades

${ }^{139}$ A primeira campanha terá sido organizada em 460-459 a.C. para ajudar Inaro, rei da Líbia, que pretendia criar no Egipto um reino independente do persa. Depois de conquistar Mareia (região próxima da futura Alexandria), sentiu dificuldades em controlar o resto do território e, consequentemente, pediu ajuda aos Atenienses. Os aliados, escolhidos sobretudo pelo seu poderio naval, não hesitaram, já que era uma óptima oportunidade de mostrar à Pérsia que era preferível ter Atenas do seu lado a tê-la como inimiga. $\mathrm{Na}$ sequência do pedido de Inaro, partiu em direcção ao Egipto parte do contingente da Simaquia de Delos que entáo se encontrava em Chipre. Nos primeiros tempos, os Atenienses conseguiram corresponder ao objectivo (Tucídides 1. 104). Mas, ao fim de seis anos, foram derrotados por Megabizo e perderam duzentos navios junto à ilha de Prosopítis (Tucídides 1. 109-110).

${ }^{140} \mathrm{O}$ interesse de Atenas pela Sicília e pelo Sul de Itália de um modo geral era muito anterior à primeira expediçáo que empreenderam àquela zona entre 427-424 a.C. (Tucídides 3. 86, $88,90,99,103,4.1-2,25,48.6,65)$. Na verdade, o crescente poderio de Siracusa constituía uma ameaça para o império ateniense, já que esta era aliada da inimiga Corinto. Péricles, porém, não julgava necessária uma intervenção de peso contra esse perigo, nem oportuno alargar o domínio ateniense para Oeste, numa altura em que alguns aliados começavam a manifestar interesse pelo abandono da Simaquia de Delos. Consequentemente, como diz Plutarco, o estadista fez o possível por evitar o avanço das propostas expansionistas e limitou-se a fomentar uma aliança com Régio e Leontinos, de modo a terem um observador atento dos movimentos de Siracusa. Porém, em 427 a.C., já depois da morte de Péricles, os Atenienses acabaram por se envolver com os problemas da Sicília, 
inflamou. Outros já sonhavam com a Etrúria e Cartago, não sem fundamento, dada a grandeza da hegemonia presente e o curso favorável dos acontecimentos.

21. 1. Mas Péricles continha esse ímpeto e sustinha esse afã. Aplicou a maior parte da força existente para guardar e assegurar o que já possuíam, pois pensava que era de si uma grande tarefa manter afastados os Lacedemónios; a este adversário opunha-se totalmente, como mostrara muitas outras vezes, sobretudo na forma como agira na Guerra Sagrada ${ }^{141}$. 2. Os Lacedemónios

visto que os aliados de Atenas combatiam contra Siracusa e estavam a passar por sérias dificuldades. $\mathrm{O}$ apoio seguiu sob a forma de vinte trirremes comandadas por Laques e Caroéades que regressaram em 424 a.C. A segunda expedição à Sicília ocorreu em 415 a.C., mais uma vez para socorrer os aliados. Desta feita, os habitantes de Segesta e uma facçáo de Leontinos buscaram o auxílio de Atenas para a guerra que travavam com Selinunte, cidade apoiada por Siracusa. Embora houvesse a obrigaçáo de não abandonar um aliado que se encontrava em dificuldades, o certo é que nem todos se mostravam a favor desta expedição que viria a ser o desastre que faltava para o princípio do fim do império ateniense. Nícias representava aqueles que não viam o aparecimento de uma nova frente de batalha com bons olhos: segundo Tucídides (6.9 sq.), aquele general desconfiava das pretensóes expansionistas que estariam por trás do nobre propósito de socorrer quem se encontrava em dificuldades, por isso defendia que náo precisavam de mais inimigos (pois já tinham que fazer frente ao inimigo espartano) e que deviam conservar o que já possuíam e deixar de lado ambiçóes desnecessárias. Alcibíades era a favor: defendia acerrimamente o apoio devido aos aliados e menosprezava quer o poder de Siracusa, quer o dos Espartanos; o que o movia era o sonho de, conquistada a Sicília, verem o seu poder reforçado e assim terem meios para subjugar toda a Grécia. Sobre este tema, vide Kagan (1981: 157 sq.).

${ }^{141}$ A guerra em questão recebeu este nome pois a sua causa foi o controlo do santuário de Delfos e do seu tesouro (Tucídides 1 . 112. 5), disputado por Fócios (aliados de Atenas) e Delfos. Sobre 
fizeram uma expedição militar a Delfos e restituíram ao seu povo o templo, que estava na posse dos Fócios. Mal se retiraram, Péricles interveio com o exército e reconduziu os Fócios. 3. Como os Lacedemónios tinham gravado o direito de consultar primeiro o oráculo ${ }^{142}$, que os Delfos lhes tinham concedido, na frente do lobo de bronze ${ }^{143}$, Péricles, depois de assegurar esse direito aos Atenienses, gravou-o no mesmo lobo, mas do lado direito ${ }^{144}$.

este acontecimento bélico, há versôes distintas da responsabilidade de Filócoro (FGrHist 328 F 34), Teopompo (FGrHist 115 F 156), Eratóstenes (FGrHist 241 F 38), mas Plutarco parece ter seguido a de Tucídides, segundo o qual os Atenienses reagiram imediatamente a seguir à intervenção dos Lacedemónios (em 448 a.C.). O facto de os Atenienses apenas avançarem após a retirada dos Espartanos evitou o recontro que seria uma violaçáo da paz firmada entre as duas cidades.

A Guerra Sagrada em causa foi a segunda; a primeira ocorreu por volta de 590 a.C. e as duas últimas já no séc. IV a.C., respectivamente entre 356 e 346 a.C. e entre 340-338 a.C.

142 Devido à importância dos oráculos de Delfos, o santuário de Apolo era muito concorrido. De todos os pontos do mundo antigo chegavam peregrinos para consultar os desígnios divinos. Com tamanha afluência, a espera era naturalmente longa e difícil, até porque o clima da região é bastante rigoroso, quer no Inverno, quer no Verão. A ordem de atendimento era decidida por sorteio. No entanto, determinados povos gozaram do direito de consultar o oráculo em primeiro lugar - a promanteia. Essa regalia era muito desejada e acabava por traduzir a importância da polis que a possuía - daí a rivalidade entre Atenas e Esparta pela detenção desse privilégio que era concedido pelo povo responsável pelo santuário.

${ }^{143} \mathrm{O}$ testemunho de Pausânias (10. 14. 7) indica-nos que o lobo ficava junto do altar-mor e que tinha sido oferecido pelos Delfos. Enquanto sacerdote do templo de Delfos e curioso de tudo o que lhe dizia respeito, é natural que o próprio Plutarco tenha lido as inscriçóes em questão.

${ }^{144} \mathrm{O}$ direito de prioridade na consulta do oráculo é também mencionado por Filócoro (FGrHist 328 F 34), que poderá ter sido a fonte de Plutarco. 
22. 1. Que com razão canalizava as forças dos Atenienses para a Grécia, os acontecimentos testemunharam-no. Primeiro sublevaram-se os Eubeus, contra os quais marchou com as tropas ${ }^{145}$. Imediatamente depois, foi anunciado que os Megarenses tinham declarado guerra e que um exército de Peloponésios, conduzido pelo rei Plistóanax ${ }^{146}$ de Esparta, assolava as fronteiras da Ática.

2. Péricles regressou com prontidão de Eubeia para a guerra na Ática, mas não se atreveu a combater contra tantos e valorosos hoplitas que o provocavam. Ao aperceber-se de que Plistóanax era extremamente jovem e de que, dentre os conselheiros, seguia sobretudo Cleândridas ${ }^{147}$, que os éforos enviaram com ele como guarda e assessor, por causa da sua juventude, Péricles abordou-o em segredo; rapidamente o convenceu

${ }^{145} \mathrm{Cf}$. Tucídides 1. 114. 1. Esta é a segunda incursão de Péricles contra Eubeia. A primeira teve lugar pouco depois da morte de Tólmides em combate, altura em que os Eubeus se rebelaram contra Atenas. A insurreição não foi logo dominada, porque, entretanto, surgiu uma nova frente de batalha, já que também Mégara causava problemas e estava iminente uma invasão da Ática liderada pelos Peloponésios (Per. 22. 1). Só depois de resolvidos estes problemas é que Péricles se pôde dedicar à questáo de Eubeia.

${ }^{146}$ Filho de Pausânias que reinou entre 458 e 408 a.C. (cf. Diodoro Sículo 11. 88. 3). Por esta altura devia ser muito jovem com cerca de vinte e cinco ou trinta anos - já que Plutarco salienta a sua juventude. Depois do fracasso desta expedição, refugiou-se na Arcádia (Per. 22. 3). Só regressou a Esparta em 427 a.C., após a morte de Arquidamo e influenciado por um oráculo pítico.

${ }^{147}$ Era provavelmente um éforo (cf. Suda, s. v. Ě lutara com Terina (Polieno 2. 10.1) e Tégea (id. 2. 10.3). Após o desterro a que Plutarco alude em Per. 22. 3, participou na fundação de Túrios (id. 2. 10). 
a deixar-se subornar e a retirar os Peloponésios da Ática ${ }^{148}$.

3. Quando o exército bateu em retirada e se dispersou pelas diversas cidades, os Lacedemónios, indignados, impuseram uma multa em dinheiro ao rei $^{149}$. Como ele náo tinha a quantia suficiente para pagar, deixou a Lacedemónia ${ }^{150}$. Quanto a Cleândridas, que se tinha afastado, foi condenado à morte ${ }^{151}$. 4. Este era pai daquele Gilipo que derrotou os Atenienses na Sicília ${ }^{152}$. Parece que a natureza transmitiu ao filho, como uma doença hereditária, a mesma ambição; esse foi o motivo por que, surpreendido em delito, depois de actos notáveis, foi também vergonhosamente expulso de Esparta. Contámos este episódio na Vida de Lisandro.

23. 1. Péricles registou, nas contas do seu mandato de estratego, uma despesa de dez talentos

148 O suborno de Cleândridas é apontado como causa da retirada espartana em Tucídides 2. 21. 1, 5. 16. 3. Éforo (FGrHist $70 \mathrm{~F}$ 193) relaciona-o com os vinte talentos que faltavam nas contas apresentadas por Péricles (em Per. 23. 1, o valor indicado é de apenas dez talentos).

${ }^{149}$ Quinze talentos segundo Éforo (FGrHist 70 F 193) e cinco

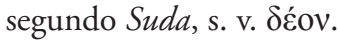

150 Plistóanax refugiou-se no santuário de Zeus Liceu, na fronteira com a Arcádia. Foi-lhe permitido regressar a Esparta e ao trono em 427 a.C. Segundo Tucídides (5. 16. 1-3), apoiou a Paz de Nícias em 421 a.C. e reinou até à sua morte em 408 a.C.

${ }^{151}$ Viveu exilado em Túrios, onde ficou famoso como general (cf. D. S. 13. 106. 10; Antíoco Histórico FGrHist 555 F 11; Tucídides 6. 93. 2; Polieno 2. 10.).

${ }^{152}$ Em 414-413 a.C. Cf. Plutarco, Nícias 28. Foi desterrado porque, após a rendição dos Atenienses, roubou trinta dos mil talentos de saque que Lisandro lhe confiara e escondeu-os debaixo do telhado da sua casa (cf. Plutarco, Lisias 16. 2-17). 
dispendidos como gastos diversos ${ }^{153}$. O povo aprovou sem se intrometer e sem questionar o mistério. 2. Contam alguns ${ }^{154}$, dentre os quais o filósofo Teofrasto, que iam anualmente para Esparta da parte de Péricles dez talentos, com os quais, adulando todos os que estavam no poder, adiava a guerra. Não comprava a paz, comprava tempo, para se preparar calmamente para combater com vantagem.

3. Voltou-se de novo contra os rebeldes, atravessou Eubeia com cinquenta navios e cinco mil hoplitas e submeteu as várias cidades ${ }^{155}$. 4. Expulsou de Cálcis os chamados Hipóbotas ${ }^{156}$, que se distinguiam pela riqueza e pela reputação. Fez partir da sua terra todos os Hestieus e aí instalou Atenienses ${ }^{157}$ - só a estes tratou de

153 Este episódio também é mencionado por Aristófanes em Nuvens 858-859. Segundo o escoliasta deste passo, que provavelmente se baseou em Éforo (FGrHist 70 F 193), a soma era de vinte talentos. Suda s.v. $\delta$ śov refere cinquenta talentos.

${ }^{154}$ Apesar do plural, é provável que Plutarco apenas tivesse em mente Teofrasto, já que este episódio não é relatado em mais nenhuma parte. No entanto, a reacçấo dos Espartanos face ao comportamento de Plistóanax e Cleândridas não confere grande veracidade ao testemunho de Teofrasto: se náo conseguiram admitir um suborno momentâneo, como iriam suportá-lo por dez anos?

${ }^{155}$ Cf. Tucídides 1. 114. 3; Plutarco supra Per. 22. 1.

156 "Criadores de cavalos". Trata-se da classe rica de Cálcis que foi muito penalizada pela cleruquia de 506 a.C. (Heródoto 5. 7477). Segundo Stadter (1989: 232), os Hipóbotas teriam liderado uma revolta contra os Atenienses para instaurar uma oligarquia, mas acabaram por ser expulsos; assim, após o estabelecimento da cleruquia, só em 446 a.C. teria sido possível pôr termo à oposição da classe rica. MANFREDINI (1968: 199-212) pensa que esta referência de Plutarco é uma versão errada da narração de Heródoto sobre os factos de 506 a.C.

${ }^{157}$ Esta colónia recebeu o nome de Oreu e foi uma importante base ateniense na costa norte de Eubeia até ao fim da Guerra do 
modo inflexível, porque tomaram uma nau ática como prisioneira de guerra e mataram a tripulaçãa ${ }^{158}$.

24. 1. De seguida, firmada uma trégua de trinta anos entre Atenienses e Lacedemónios ${ }^{159}$, decretou uma expedição naval contra Samos ${ }^{160}$, acusando os seus habitantes de, apesar de exortados a terminarem a guerra contra Mileto, não obedecerem. 2. Mas, como parece que fez guerra contra Samos para agradar a Aspásia ${ }^{161}$, talvez seja então a melhor ocasião para questionar esta mulher, que arte ou poder tão grande tinha, que dominava os

Peloponeso (Tucídides 8. 95. 7). Teopompo (FGrHist 115 F 387) acrescenta ainda que os clerucos eram em número de mil e que os Hestieus emigraram para a Macedónia.

${ }^{158}$ Esta explicação é exclusiva de Plutarco.

${ }^{159}$ No Inverno de 445-444 a.C. (cf. Tucídides 1. 115. 1).

${ }^{160}$ A guerra de Samos ocorreu entre 441-439 a.C., cinco anos após a celebraçáo do tratado de paz (Tucídides 1. 115. 2). Samos fazia parte da Simaquia, mas tinha uma frota própria e tinha entrado em guerra contra Mileto pela posse de Priene.

${ }^{161}$ A extraordinária influência que se atribui a Aspásia na sociedade ateniense fez com que fosse a mulher grega que melhor se conhece. No entanto, a informação de que dispomos é invariavelmente escassa e por vezes pouco fidedigna. As principais fontes sobre esta figura são as comédias e ainda os diálogos socráticos, nomeadamente as duas Aspásia de Ésquines Socrático e de Antístenes e o Menéxeno de Platão. Importa desde já lembrar que da mulher ateniense nấo se esperava um empenho activo na vida pública; o próprio facto de se conversar ou beber com um homem era sinónimo de vida devassa. Recordemo-nos, contudo, de que Aspásia era estrangeira e possivelmente hetera - e o facto de ela conseguir vencer essas limitaçôes só reforça a excepcionalidade do seu carácter.

Para um melhor conhecimento da situação da mulher na Grécia antiga, leiam-se, por exemplo, Gomme (1937: 89-115); Mossé (1983). 
principais políticos e aos filósofos oferecia matéria, nem má nem pouca, para falarem dela. 3. Que era de origem milésia e filha de Axíoco, todos estão de acordo. Dizem que era para igualar Targélia ${ }^{162}$, uma das antigas cortesâs iónicas, que se entregava aos homens mais poderosos. 4 . Targélia, que era bela e combinava graça com subtileza, teve muitíssimos homens gregos e atraía para a causa do rei persa todos os que dela se aproximavam. E assim, por meio deles, que eram homens poderosos e influentes, espalhou nas respectivas cidades sementes de adesão à Pérsia. 5. Há quem afirme que Aspásia conquistou o apreço de Péricles pela inteligência e capacidade política de que era dotada. Também Sócrates a visitava algumas vezes com os discípulos, e os que lhe eram íntimos levavam as mulheres para a escutarem, embora dirigisse um negócio que era tudo menos honrado e digno, pois mantinha jovens prostitutas. 6. Ésquines diz que Lísicles ${ }^{163}$, o comerciante de gado, um sujeito de origem humilde e de baixa índole, se tornou o primeiro dos Atenienses, por ter passado a viver com Aspásia depois da morte de Péricles. 7. No Menéxeno ${ }^{164}$ de Platão,

${ }^{162}$ Famosa cortesã de Mileto que fez com que a Tessália, de cujo monarca era amante, cedesse à Pérsia por altura da invasão de Xerxes.

${ }^{163}$ F8, 46 Krauss. Trata-se de um dos demagogos que antecederam Cléon. Alude-se ao matrimónio de Lísicles e Aspásia no escólio a Platão, Menéxeno 235e, que menciona o filho de ambos, Poristes, e informa também que Aspásia fez dele um importante orador. Aristófanes faz referência a Lísicles em Cavaleiros 132 e 765.

${ }^{164}$ Menéxeno 235e. Neste diálogo, durante um encontro com Menéxeno, Sócrates recita uma oração fúnebre fictícia destinada às celebraçóes públicas dos caídos em 386 a.C. na expedição à Sicília, e que teria sido escrita por Aspásia. 
embora o texto de abertura esteja escrito em tom jocoso, existe algum fundamento histórico no facto de Aspásia ter fama de se reunir com muitos Atenienses com objectivos retóricos. Mas parece que a afeição de Péricles por Aspásia foi certamente de índole amorosa.

8. Péricles tinha por mulher uma sua parente consanguínea ${ }^{165}$, que casara em primeiras núpcias com Hiponico $^{166}$, de quem deu à luz Cálias, o milionário. De Péricles, teve Xantipo e Páralo. Depois, como a convivência entre eles não era agradável, entregou-a de comum acordo - a outro; e ele ficou com Aspásia, a quem amou com especial ternura. 9. Diz-se ${ }^{167}$ que, todos os dias, quando saía da ágora ou nela entrava a saudava com um beijo. Nas comédias, ela aparece como uma nova Ônfale, Dejanira e como Hera. Cratino chama-lhe directamente concubina nestes versos: "A Sem-Vergonhice dá à luz esta Hera, Aspásia, uma concubina de olhos de cadela." 168

165 Não se sabe ao certo quem foi a primeira esposa de Péricles. Bicknell (1972: 79) defende tratar-se de uma irmá de Dinómaca, máe de Alcibíades. Já Cromey (1982: 203-212) admite que se trata da própria Dinómaca.

166 Filho de Cálias e Elpinice, a irmá de Címon. Fazia parte de uma família muito rica e politicamente activa. Em 427-426 a.C., dirigiu como estratego a expedição contra Tânagra. Faleceu pouco antes de 422 a.C. O Protágoras de Platáo decorre em casa de Cálias, que hospedou o famoso sofista (315e).

167 Antístenes (F1 Dittmar).

168 Fr. 259 K.-A. Neste fragmento, faz-se a genealogia de Aspásia, transformando a normal conotação de dignidade e nobreza do tom épico em vulgaridade gritante. $\mathrm{O}$ epíteto homérico de Hera - boopis - cujo significado literal é "de olhos de vaca", ao que parece, a simbolizar a grandeza dos olhos e a mansidão do olhar -, é adaptado para kynopis "olhos de cadela", como sinónimo de sem- 
10. Parece que teve dela um bastardo ${ }^{169}$, sobre quem Êupolis, em Demos, faz Péricles perguntar assim:

"E o meu bastardo, está de boa saúde?"

E Pirónides responde-lhe:

"Está e de há muito seria um homem feito, se não o abalasse o mal da marafona. ${ }^{170}$

11. Dizem que Aspásia se tornou tấo célebre e famosa que até Ciro $^{171}$, aquele que disputou com o Rei Persa a soberania, chamou Aspásia à sua concubina preferida, que antes se chamava Milto. 12. Era essa mulher de origem fócia e filha de Hermotimo. Quando Ciro morreu em combate, foi levada para junto do Rei e tornou-se influente. Este caso veio-me à memória enquanto escrevia - e era talvez pouco natural omiti-lo e passá-lo por alto.

25. 1. Quanto à guerra contra Samos, acusam Péricles de a ter decretado sobretudo por causa de Mileto,

-vergonhice, o que mostra bem que, pelo menos entre os cómicos, Aspásia não era muito bem vista.

${ }^{169}$ Filho de Péricles mencionado em Per. 37. 2-5. Esta peça, que data de 412 a.C., é já bastante posterior à morte do estadista.

${ }^{170}$ Refere-se provavelmente ao medo que o filho teria de se propor para cargos públicos devido à fama da mãe.

${ }^{171}$ Ciro o Moço, filho de Dario II e Parisátis, que, em 401 a.C., organizou uma expedição para retirar o poder ao seu irmão Artaxerxes (cf. Xenofonte, Anábase 1). Sobre o seu amor por esta Aspásia, vide Eliano, Varia Historica 12. 1; Plutarco, Artaxerxes 26. 5-9. 
a pedido de Aspásia ${ }^{172}$. As duas cidades estavam em guerra por causa de Priene ${ }^{173}$ e os Sâmios, que levavam vantagem, não obedeceram quando os Atenienses mandaram terminar o combate e deixar a resolução do litígio a seu cargo ${ }^{174}$.

2. Péricles fez-se ao mar e derrubou a oligarquia que existia em Samos. Tomou cinquenta dos principais cidadãos e igual número de crianças como reféns e enviou-os para Lemnos ${ }^{175}$. Diz-se que cada um destes reféns lhe ofereceu um talento em favor próprio; e que os que náo queriam que na cidade existisse uma democracia lhe ofereceram muito mais. 3. Além disso o persa Pissutnes ${ }^{176}$, que tinha certa simpatia pelos Sâmios, enviou-lhe dez mil moedas de ouro, intercedendo pela cidade. Contudo, Péricles não aceitou nenhuma dessas

${ }^{172}$ Importa recordar que Aspásia era natural de Mileto, cidade hostil a Samos.

${ }^{173}$ Pequena cidade iónia na foz do Meandro, próxima de Mileto (a Norte) e de Mícale, que controlava o santuário comum de Paniónion. A guerra pode ter sido motivada pela mudança da festa de Priene para Éfeso. Cf. Hornblower (1982: 241-245).

174 Provavelmente os Atenienses argumentavam que os membros da Simaquia de Delos deveriam respeitar os aliados uns dos outros.

${ }^{175} \mathrm{O}$ número de reféns coincide com o que Tucídides (1. 115. 3) apresenta. Fazer reféns era um hábito, cujo principal objectivo era garantir o bom comportamento da cidade sobre a qual recaíam as suspeitas. Neste caso, os reféns foram enviados para Lemnos porque era uma ilha próxima da Ásia Menor onde havia uma cleruquia ateniense (conquistada por Milcíades em 500 a.C.) e porque também era membro da Simaquia de Delos.

176 Filho de Histaspes, sátrapa de Sardes e provavelmente sobrinho de Xerxes, que fomentou a revolta dos Sâmios e também se intrometeu nos assuntos gregos durante a revolta de Mitilene. 
ofertas ${ }^{177}$, tratou os Sâmios como pensara e, depois de estabelecer a democracia, zarpou para Atenas.

4. Mal os Atenienses se afastaram, Pissutnes roubou os reféns para os devolver a Samos e ultimou todos os preparativos para a guerra ${ }^{178}$. Então Péricles fez-se novamente à vela contra eles ${ }^{179}$, que nem estavam inactivos nem com medo; pelo contrário, estavam terminantemente decididos a apoderar-se do mar. 5. Depois de um combate marítimo violento ao redor da ilha a que chamam Trágia, Péricles obteve uma esplêndida vitória, derrotando, com quarenta e quatro barcos, setenta, vinte dos quais transportavam tropas ${ }^{180}$.

177 Plutarco, ao referir a tentativa de suborno dos Sâmios e de Pissutnes, foge ao texto de Tucídides, que nada diz a esse respeito. Ao que parece, era até normal tentar dar dinheiro em troca de reféns. Mas Péricles, ao contrário de Plistóanax (Per. 22. 2), não cai em tentação. Outras fontes, no entanto, náo apoiam de forma tâo evidente a incorruptibilidade de Péricles. Diodoro Sículo (12. 27. 2), por exemplo, diz que aquele recebeu oitenta talentos dos Sâmios e que enviou para Lemnos oitenta crianças.

${ }^{178}$ Tucídides explica que foi uma revolta levada a cabo por um grupo de Sâmios que, aquando da primeira expedição, se havia refugiado no continente. O primeiro passo desta sublevação foi prender os democratas e libertar os reféns. Depois de entregarem a guarnição e os magistrados atenienses a Pissutnes, logo voltaram a atacar os Milésios (Tucídides 1. 115. 4-5).

179 Tucídides (1. 116. 1) precisa que Péricles era um dos dez generais e que a expediçáo era constituída por um total de sessenta embarcaçóes, das quais dezasseis foram para a Cária vigiar os navios fenícios e buscar ajuda a Quios e a Lesbos.

${ }^{180}$ Os números aqui apresentados são os mesmos que surgem em Tucídides 1. 116. 1. Quanto à ilha de Trágia, situa-se a doze milhas ao sul de Samos e a dezasseis a oeste de Mileto. 
26. 1. Com a vitória e a retirada do inimigo, apoderou-se do porto, sitiou os Sâmios, que, de uma maneira ou de outra, ainda se atreveram a sair e a combater em frente às muralhas ${ }^{181}$. Mas depois que chegou de Atenas uma outra frota maior ${ }^{182}$, os Sâmios ficaram completamente encurralados. Péricles, levando sessenta trirremes, navegou para o mar largo, como é voz corrente ${ }^{183}$, para interceptar os navios fenícios ${ }^{184}$ que vinham em auxílio dos Sâmios, pois queria ir ao seu encontro e lutar o mais longe possível; ou, segundo Estesímbroto $^{185}$, porque tinha por objectivo Chipre - o que não se afigura verosímil.

2. Qualquer que fosse a sua intenção, parece que cometeu um erro. Mal partiu, Melisso ${ }^{186}$, filho de

${ }^{181}$ Esta fase da guerra, que decorreu no período entre a batalha de Trágia e a chegada de novos contingentes, não é descrita nem por Tucídides nem por Diodoro Sículo.

${ }^{182}$ Constituída por quarenta navios vindos de Atenas e vinte e cinco de Lesbos e Quios, o que perfazia o total de cento e vinte e cinco embarcaçóes (cf. Tucídides 1. 116. 2).

${ }^{183}$ Cf. Tucídides 1. 116. 3; Diodoro Sículo 12. 27.5.

${ }^{184}$ Os Atenienses, por causa de Pissutnes, temiam que a Pérsia tentasse aproveitar-se da revolta de Samos para fragilizar o controlo que tinham do mar Egeu, muito embora a Paz de Cálias estivesse em vigor.

${ }^{185}$ FGrHist 107 F 8.

186 Pouco se sabe acerca da vida de Melisso, filho de Itágenes e um dos últimos representantes da escola eleática, além do facto de ter sido estadista de Samos e de ter derrotado Péricles no combate naval de 441 a.C. Este filósofo seguia as ideias de Parménides, embora não se possa garantir que alguma vez se tivessem conhecido pessoalmente. Vide Guthrie (1969: 101 sq.). Sobre a batalha em causa no texto em estudo, cf. Plutarco, Temistocles 2. 5. Nem Tucídides, nem Diodoro Sículo referem a sua participação neste combate. 
Itágenes, um filósofo que era então general de Samos menosprezando o pequeno número de $\operatorname{barcos}^{187}$ e a inexperiência dos estrategos ${ }^{188}$, convenceu os concidadáos a atacar os Atenienses. 3. Na batalha que teve lugar, os Sâmios saíram vencedores, capturaram muitos inimigos, destruíram muitos barcos, ganharam o controlo do mar e abasteceram-se do que necessitavam para a guerra e que antes náo possuíam. Aristóteles diz mesmo que Péricles já tinha sido vencido por Melisso num combate marítimo anterior ${ }^{189}$.

4. Os Sâmios, em retaliação, tatuaram a testa dos prisioneiros atenienses com corujas: é que os Atenienses tinham-no feito com uma samena ${ }^{190}$. A samena é um

${ }^{187}$ Sobre o número de embarcações que estariam naquela altura na região, vide Tucídides 1.116. 1-2.

${ }^{188}$ Andrócion (FGrHist 324 F38) indica o nome de oito dos generais de 441-440 a.C., entre os quais se encontram Péricles e Sófocles (cf. Per. 8. 8).

${ }^{189}$ Este passo é o próprio fragmento (fr. 577 Rose). É provável que Plutarco tenha colhido esta informação na Constituição de Samos ou em outras fontes sâmias que consideravam a batalha de Trágia vitória sua, já que os Sâmios tinham sido capazes de regressar de Mileto em segurança.

${ }^{190}$ A tatuagem na fronte era frequente entre os Gregos, sobretudo entre os escravos, com o objectivo de indicar propriedade. Segundo vários testemunhos, também os vencedores de guerra marcavam o inimigo com o símbolo da sua cidade. Por exemplo, os Siracusanos tatuaram um cavalo, símbolo de Siracusa, nos Atenienses capturados na expedição de Nícias e Demóstenes (cf. Plutarco, Nícias 29. 2). Este episódio que Plutarco aqui relata tem como fonte Dúris (FGrHist 76 F 66). Mas, ao que parece, o Queroneu "troca" alguns dados da história: é que segundo vários testemunhos (e. g. Fócio e

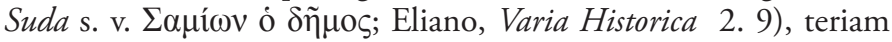
sido os Atenienses a utilizar a coruja nos Sâmios; estes, por sua vez, "presentearam" os Atenienses com samenas. Mas a versão de

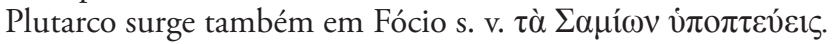


barco de proa em forma de focinho de porco, muito côncava e bojuda, boa para transportar cargas e navegar com rapidez ${ }^{191}$. Chama-se assim porque apareceu pela primeira vez em Samos e foi construída pelo tirano Polícrates ${ }^{192}$. Dizem que a estas tatuagens faz alusão o verso de Aristófanes: "O povo de Samos, que gente letrada!" 193

27. 1. Ora, quando Péricles foi informado do revés da armada, acorreu rapidamente em seu socorro ${ }^{194}$;

191 Embora outros autores se refiram a esta embarcação (e. g. Quérilo de Samos, F. 6, 269 Hinke), esta é a descrição mais completa que se possui. Sobre este assunto, leia-se CAsson (1971: 63).

192 Tirano que esteve no poder desde 538 até 522 a.C., ano em que foi assassinado pelo sátrapa persa Oretes (Heródoto, Histórias 3. 120-125). Subjugou as cidades costeiras da Ásia Menor e as ilhas e, segundo indicação do livro 2 de Nostoi do gramático Lisímaco (vide Fócio, s.v. $\Sigma \alpha \mu i ́ \omega v$ o $\delta \tilde{\eta} \mu \mathrm{o}$ ), foi sob a sua égide que apareceram as primeiras samenas.

${ }^{193}$ F. 71 K.-A. Este trímetro iâmbico era parte da peça Babilónios (426 a.C.), na qual os Sâmios eram comparados a escravos. Fócio e Suda (nas entradas já citadas) propuseram explicaçóes para este verso na Antiguidade. Welsh (1983: 137-150) sugere que o adjectivo polygrammatos faz ironicamente alusão às samenas que os Atenienses tatuaram nos Sâmios por ocasião da rebelião de 440 a.C., como marca da submissão devida ao líder da Simaquia de Delos. Penso que esta interpretação é legítima, na medida em que o sentido denotativo de polygrammatos é, precisamente, "marcado com muitos traços ou letras". Houve ainda outro motivo que me fez optar por traduzir polygrammatos por "letrado": é que já entre os latinos esta palavra servia para designar o tipo de marcas em causa no contexto deste verso, como atestam K.-A. (1983-1995: III. 2, 66) - litteratus appellatur apud Plautum seruus stigmatis nota inustus.

${ }^{194}$ Tucídides (1. 117. 2) refere-se a um reforço constituído por quarenta barcos sob o comando de Tucídides, Hágnon e Formião 
venceu Melisso, que lhe fez frente, e logo depois, perseguiu e sitiou os inimigos no interior das muralhas, pois preferia dominá-los e conquistar a cidade à força de dinheiro e de tempo a fazê-lo com feridas e perigos para os seus concidadáos. 2. Como era obra conter os Atenienses quando ficaram impacientes com a demora e desejosos de combater, Péricles dividiu toda a tropa em oito partes e fez um sorteio: à que obtinha a fava branca $^{195}$, permitia que fizesse um festim e descansasse, enquanto as outras se afadigavam. 3. É este o motivo por que se diz que, por causa da fava branca, quem passa um dia na farra lhe chama "dia branco" ${ }^{196}$.

Éforo ${ }^{197}$ diz que Péricles se servia de engenhos de guerra, na admiração que sentia pela sua novidade, e que era assistido pelo engenheiro Ártemon ${ }^{198}$. Este,

e por vinte sob o de Tlepólemo e Ânticles (num total de sessenta barcos vindos de Atenas) e mais trinta oriundos de Quios e Lesbos.

${ }^{195} \mathrm{O}$ meio mais frequente de se fazer um sorteio em Atenas era retirar de um recipiente a fava branca que estava misturada com pretas. festivos.

196 Trata-se de uma expressão grega utilizada para referir dias

${ }^{197}$ FGrHist $70 \mathrm{~F}$ 194. Éforo de Cime (ca. 405-330 a.C.) foi contemporâneo de Teopompo e discípulo de Isócrates. Este historiador escreveu um livro sobre as tradiçóes da sua cidade natal e um tratado sobre aspectos que despertavam a curiosidade das gentes do tempo, intitulado Sobre Invençóes; mas a sua obra principal é Histórias, a primeira história universal, em trinta volumes, que serviu de fonte a vários autores, dentre os quais Diodoro Sículo, Estrabão, Polieno e Plutarco. Foi, depois de Xenofonte, o historiador mais importante do séc. IV a.C. Vide Lesky (1995: 659-660).

198 Trata-se de um engenheiro oriundo de Clazómenas, ao qual se atribui a invenção do testudo militar (testudines) para cobrir o aríete (Diodoro Sículo 12. 28. 3; Plínio, História Natural 7. 201). Consta que era coxo e que, por essa razão, se fazia transportar em 
como era coxo, era transportado numa liteira para os trabalhos urgentes, pelo que lhe chamavam Periforeto. 4. Mas Heraclides Pôntico ${ }^{199}$ refuta essa afirmação com poemas de Anacreonte, nos quais se menciona um Ártemon periforeto muitas gerações antes da Guerra de Samos e daqueles acontecimentos. Diz ainda que Ártemon tinha hábitos sofisticados e, diante do medo, era cobarde e assustadiço; assim ficava muito tempo em casa com dois escravos que lhe seguravam um escudo de bronze sobre a cabeça para que nada do tecto lhe caísse em cima. Se era forçado a sair, fazia-se transportar numa liteira suspensa a pouca distância do chão e por isso lhe chamaram Periforeto.

28. 1. Quando, oito meses passados, Samos se rendeu, Péricles destruiu-lhe as muralhas, confiscou-lhe os navios e impôs-lhe pesadas multas em dinheiro, de que os Sâmios entregaram logo parte; o resto, comprometeram-se a pagá-lo em tempo convencionado e deram reféns de garantia $^{200}$.

liteiras, o que lhe valeu a alcunha de Periforeto - "o que vai de liteira”. No entanto, Anacreonte já havia atribuído a mesma alcunha a um outro indivíduo chamado Ártemon, famoso pelo seus hábitos sofisticados, que se fazia transportar não por deficiência física, mas por comodidade e ostentação. Vide fr. 43 Page.

${ }^{199}$ F. 60 Wehrli. Heraclides (ca. 390-310 a.C.) era um filósofo académico, oriundo de Heracleia, no Mar Negro. Almejou, em vão, aceder à direcção da Academia em 339 a.C., facto que o fez regressar entâo à sua terra natal. Conhecemos os títulos de quarenta e seis diálogos da sua autoria; de acordo com Diógenes, subdividiam-se em três grupos: o primeiro de cariz cómico, o segundo trágico, e o terceiro mais destinado a filósofos, políticos e militares. Vide GUTHRIE (1969: 483-489).

${ }^{200}$ Cf. Tucídides 1. 117. 3. Este acontecimento teve lugar 
2. Dúris de Samos ${ }^{201}$ imaginou a propósito destes acontecimentos uma grande tragédia, acusando os Atenienses e Péricles de muita crueldade, o que nem Tucídides, nem Éforo ou Aristóteles registam. Mas não parece que diga a verdade, quando afirma que então Péricles levou os trierarcas e os marinheiros dos Sâmios para a ágora dos Milésios e os crucificou durante dez dias. E, quando já estavam mal, mandou matá-los com pauladas na cabeça e em seguida abandonar os corpos insepultos. 3. Mas Dúris que, nem mesmo quando não tinha interesses particulares envolvidos, costumava manter a narrativa dentro da verdade, com toda a probabilidade, neste caso em especial, exagerou os sofrimentos da sua pátria para deixar mal vistos os Atenienses ${ }^{202}$.

4. Quando, depois de ter dominado Samos, Péricles regressou a Atenas, fez funerais gloriosos aos que morreram durante a guerra e granjeou muita admiração,

provavelmente nos princípios de 439 a.C.

${ }^{201}$ FGrHist 76 F 67. Dúris (ca. 340 - 260 a.C.) foi historiador, discípulo de Teofrasto e sucedeu ao seu irmão Linceu na tirania de Samos, sua terra natal. Escreveu, entre outros títulos, uma obra chamada Histórias (sobre o período entre 370 e 281 a.C.) e uma Crónica de Samos (que abrangia os acontecimentos desde o século VII ao $\mathrm{V}$ a.C.). Não foi um autor muito influente, porque além de o seu estilo ser pobre, era demasiado sensacionalista. Vide LESKY (1995: 806 sq.).

202 Plutarco tinha interesses biográficos ao refutar as acusações de Dúris, pois pretendia pôr em evidência a moderação e a humanidade de Péricles. No entanto, consta que os Atenienses, em tempo de guerra, aplicavam duros castigos aos traidores ou a qualquer outro tipo de "criminoso" (isto é, a quem quer que fosse responsável por uma conduta menos própria), como testemunha Diodoro Sículo (12. 28. 3). 
quando, como é costume, proferiu um discurso junto aos túmulos ${ }^{203}$. 5. Mas ao descer da tribuna, enquanto as outras mulheres lhe apertavam a mão e o galardoavam com coroas e fitas, como a um atleta vencedor, Elpinice aproximou-se e disse-lhe: 6. "Que feitos admiráveis e dignos das coroas os teus, Péricles! Tu que fizeste perecer muitos dos nossos valorosos cidadãos, não a fazer guerra contra os Fenícios e contra os Medos, como o meu irmão Címon, mas a destruir uma cidade aliada e da mesma raça da nossa." 7. Contam que, ao ouvir Elpinice, Péricles sorriu calmamente e lhe recitou este verso de Arquíloco: "Velha como és, não devias encharcar-te em perfumes." 204

Íon ${ }^{205}$ afirma que Péricles sentia um orgulho fantástico e imenso por ter vencido os Sâmios, já que, em nove meses, conquistou os primeiros e mais poderosos dos Iónios, enquanto Agamémnon levou dez anos a tomar uma cidade bárbara. 8. E não era descabida essa opinião, porque, na verdade, a guerra trouxe muita

${ }^{203}$ Tucídides descreve a cerimónia em 2. 34. A oração fúnebre (epitaphios logos) era um elogio feito anualmente em Atenas aos que perdiam a vida no campo de batalha. Servia, assim, não só para glorificar os heróis (e, deste modo, convencer os vivos de que morrer por Atenas era uma honra), como a própria polis e os ideais por ela defendidos. Para isso, segundo Aristóteles, que na Retórica nos fala dos discursos epidícticos (nos quais o epitaphios logos se inclui), estes devem incluir referências aos acontecimentos passados e especulaçóes sobre os futuros - o que equivale a dizer que é preciso apelar às memórias gloriosas e aos sonhos de grandeza dos ouvintes. É esse o esquema de oração fúnebre que Tucídides atribui a Péricles, uma das poucas que chegaram até nós.

${ }^{204}$ Fr. 27 Diehl, também citado por Ateneu 688e.

${ }^{205}$ FGrHist 392 F 16. 
incerteza e grande perigo, se, como diz Tucídides ${ }^{206}$, a cidade de Samos por pouco náo usurpou aos Atenienses o domínio do mar.

29. 1. Depois destes acontecimentos, quando a Guerra do Peloponeso começou a fervilhar, convenceu o povo a enviar auxílio aos Corcireus no seu diferendo com Corinto e a associar-se a uma ilha forte pelo seu poder naval, já que os Peloponésios estavam quase a declarar-lhes guerra ${ }^{207}$. Mal o povo aprovou a ajuda, enviou

2068.76 .4 .

${ }^{207}$ Por causa dos interesses biográficos que o levam a salientar o protagonismo de Péricles, Plutarco omite várias vitórias que tiveram lugar entre a expediçáo contra Samos e a embaixada de Corcira, motivada pela disputa da posse de Epidamno com Corinto (em meados de 443 a.C.).

Epidamno era uma colónia de Corcira, que, por sua vez, era colónia de Corinto. Situada na costa norte da Ilíria, viu-se devastada por uma luta interna que culminou numa guerra com os bárbaros vizinhos incitados pelos aristocratas exilados de Epidamno. Aos democratas, devastados por terra e mar, não restou alternativa senão pedir auxílio a Corinto, depois de Corcira lho ter recusado. Se o objectivo de Corinto era atacar a sua colónia, foi bem sucedido, pois Corcira de imediato contactou os Epidamnianos para que se servissem da sua ajuda e dispensassem a dos Coríntios. Aqueles recusaram e Corcira cercou então a sua colónia. Como verificou que Corinto persistia, determinada, naquela política, Corcira enviou, em 435 a.C., uma embaixada à sua metrópole, mas não alcançou os seus intentos. Na Primavera de 433 a.C., depois de cerca de um ano e meio de combates, e como Corinto persistia na guerra, Corcira cumpriu a ameaça feita por ocasiáo da embaixada e pediu ajuda a Atenas. Depois de um debate aceso entre Atenienses, Coríntios e Corcireus, os primeiros decidiram auxiliar Corcira.

Aristodemo (FGrHist 104, 17) resume este episódio e, como Tucídides (1. 55. 2), apresenta-o como uma das causas da Guerra do Peloponeso. 
Lacedemónio ${ }^{208}$, filho de Címon, com apenas dez navios, como para insultá-lo. De facto, a família de Címon tinha muita simpatia e amizade pelos Peloponésios. 2. Assim, para que Lacedemónio fosse ainda mais contestado pelo seu laconismo, se nenhum feito grande ou notável fosse executado sob seu comando, entregou-lhe poucas embarcaçóes e enviou-o contra a sua vontade. Em geral, passou a vida a desacreditar os filhos de Címon que nem sequer nos nomes eram genuínos, mas ilegítimos e estrangeiros, porque um se chamava Lacedemónio, o outro Téssalo, e o terceiro, Eleio. Julgava-se que todos nasceram de uma mulher da Arcádia ${ }^{209}$.

3. Quando Péricles foi duramente criticado por causa das tais dez trirremes, por ter oferecido pequena ajuda aos necessitados e grande pretexto aos detractores, enviou então muitas outras para Corcira, que chegaram depois da batalha ${ }^{210} .4$. Aos Coríntios, que se irritaram

${ }^{208}$ Tucídides (1. 45. 1-2) refere ainda como estrategos Diótimo de Estrômbico e Próteas de Épicles.

${ }^{209}$ Os nomes dos três filhos de Címon correspondem a regióes da Grécia: Lacedemónia e Élide, que se situam no Peloponeso, e Tessália, a Norte da Península dos Balcâs. A origem estrangeira da máe tornava-os vulneráveis por causa da lei de 451 a.C., segundo a qual, para que um filho fosse legítimo, ambos os pais teriam de ser cidadãos atenienses. Embora não afectasse os filhos de Címon, por não ser retroactivo, este decreto impedia o reconhecimento legal do filho de Péricles e Aspásia. Sobre este assunto vide Per. 37. 5.

${ }^{210}$ Tucídides (1. 50. 5) e Diodoro Sículo (12. 33. 4) falam em mais vinte embarcaçóes, cujo envio, segundo este último, já estava previsto em caso de necessidade. De acordo com estes historiadores, os barcos chegaram quando os Corcireus já batiam em retirada das ilhas Síbotos. Ao ver os Atenienses, também os Coríntios se retiraram, o que deu a vitória aos aliados. 
e acusaram os Atenienses em Esparta ${ }^{211}$, associaram-se os Megarenses, culpando aqueles de os afastarem e excluírem de todos os mercados e de todos os portos que dominavam, contra os direitos comuns e os juramentos feitos pelos Gregos. 5. Os Eginetas, que se julgavam oprimidos e maltratados ${ }^{212}$, pediram às ocultas ajuda aos Lacedemónios, pois não se atreviam a acusar publicamente os Atenienses. 6. Entretanto também Potideia $^{213}$, cidade aliada de Atenas, mas colónia de Corinto, desertou e foi bloqueada, o que apressou ainda mais a guerra.

7. Apesar de tudo, foram enviadas embaixadas a Atenas $^{214}$ e Arquidamo, rei dos Lacedemónios, procurou resolver a maior parte das queixas e acalmar os aliados ${ }^{215}$.

${ }^{211}$ Sobre as acusaçóes em causa, feitas em Esparta durante uma reunião que decorreu em 432 a.C. (Tucídides 1. 67), as fontes nada nos dizem de concreto. De acordo com Tucídides, os principais instigadores da guerra foram precisamente os Megarenses e os Eginetas (Tucídides 1. 67. 2), mas refere-os por ordem diferente da de Plutarco, o que realça a importância que o biógrafo dá ao decreto de Mégara (Per. 30. 2-4) como causa da guerra.

${ }^{212}$ Uma das cláusulas da Trégua dos Trinta Anos foi a concessão de autonomia a Egina, embora a ilha continuasse a pagar tributo a Atenas e a fazer parte da Simaquia de Delos. Nos debates em Esparta, que antecederam o eclodir da Guerra do Peloponeso, os Eginetas acusaram os Atenienses de não terem cumprido o combinado, pelo que incorriam em violação do acordo, legitimando assim o início de hostilidades militares.

${ }^{213}$ Colónia coríntia, situada no istmo da península de Palene, que apesar dos fortes laços que a ligavam à metrópole era aliada de Atenas. Descontente por ter visto o valor do seu tributo duplicar, revoltou-se em 433 a.C., quando, depois de Síbotos, Atenas, suspeitando dos planos de secessáo, ordenou que deitassem as muralhas abaixo (Tucídides 1. 56-66).

${ }^{214}$ Vide Tucídides 1. 85-139.

${ }^{215}$ Cf. Tucídides 1. 80-85. 2. 
Ao que parece, náo era pelos outros motivos que a guerra teria sobrevindo aos Atenienses, se se tivessem comprometido a revogar o decreto de Mégara ${ }^{216}$ e a reconciliar-se com eles ${ }^{217}$. 8. Foi por isso que Péricles, que se opunha a essa cedência mais do que ninguém e incitava o povo a persistir na rivalidade com os Megarenses, foi considerado o único responsável pela guerra $^{218}$.

30. 1. Conta-se que quando chegou a Atenas uma embaixada da Lacedemónia para discutir a famosa questão e Péricles se escudou numa lei que proibia a destruição da tabuinha onde o tal decreto se encontrava escrito, um dos embaixadores, Polialces, disse: "Muito

${ }^{216} \mathrm{O}$ decreto de Mégara proibia os seus habitantes, acusados de acolherem escravos fugitivos, de entrar nos mercados de Atenas e das cidades aliadas. Esta proibição punha em causa a subsistência dos Megarenses, que, devido à exiguidade do seu território, eram forçados a obter os bens de primeira necessidade nas cidades vizinhas. Sobre este assunto, vide Fornara (1975: 213-228).

Mas os ressentimentos dos Atenienses eram mais antigos: datavam de 446 a.C., altura em que Mégara se rebelou contra Atenas e massacrou a guarnição que se encontrava no seu território. Assim sendo, o decreto vem vingar todos os ressentimentos (mesmo o cultivo do território sagrado e a morte de Antemócrito) dos Atenienses contra um antigo aliado. Sobre as causas das medidas contra os Megarenses, vide De Sainte Croix (1972: 225-289).

${ }^{217}$ Tucídides 1. 139. 1. Diodoro Sículo (12.39) afirma que essa era a condição imposta pelos Lacedemónios.

${ }^{218}$ Aristófanes (Acarnenses 515-539, Paz 601-611) bem como alguns historiadores (Diodoro Sículo 12. 39. 3-4; Aristodemo, FGrHist 104. 16; Éforo, FGrHist 70 F 196) explicam a obstinação de Péricles na não revogação do decreto de Mégara como meio de desviar a atençáo dos processos que corriam contra os seus amigos e que eram causa do decréscimo da sua popularidade. Para isso, nada melhor do que provocar uma guerra. 
bem, não destruas a tabuinha! Vira-a ao contrário! De certeza que não existe lei que o impeça." Embora a observação parecesse subtil, Péricles não cedeu um ponto.

2. Ao que parece, nutria um ódio pessoal contra os Megarenses; mas apresentou contra eles, como acusação pública eoficial, a apropriação da terrasagrada ${ }^{219}$. Promulgou um decreto para que se lhes enviasse um arauto e o mesmo também aos Lacedemónios, acusando os Megarenses. 3. Ora, este decreto, certamente de Péricles, é prudente e usa argumentos moderados. Mas quando Antemócrito, o arauto enviado, morreu - ao que parece às máos dos Megarenses $^{220}$-, foi Carino ${ }^{221}$ quem escreveu um decreto contra eles: existiria um ódio irreconciliável e inegociável entre as duas cidades; qualquer Megarense que entrasse na Ática seria castigado com a morte ${ }^{222}$; os generais, quando fizessem o juramento da tomada de posse, acrescentariam

${ }^{219}$ Refere-se a orgas, uma terra fértil que não se podia cultivar por estar consagrada à deusa de Elêusis, na fronteira com Mégara. A violação de território sagrado era uma ofensa muito grave (incorria-se em asebeia) e deu origem a outros conflitos ao longo da história da Grécia antiga: o cultivo da planície sagrada de Delfos, por exemplo, foi a causa da Guerra Sagrada de 350 a.C. (supra n. 141). Para mais pormenores e bibliografia, veja-se STADTER (1989: 277).

${ }^{220}$ Esta responsabilidade não foi provada e talvez a morte de Antemócrito tenha sido utilizada como propaganda ateniense para justificar o decreto.

${ }^{221}$ Colaborador de Péricles. Plutarco justifica este decreto contra os Megarenses com o cultivo da terra sagrada e do assassinato de Antemócrito. Stadter (1989: 279) pensa que a atribuição desta lei a Péricles é provavelmente uma simplificação cómica da parte de Aristófanes (Acarnenses 532).

${ }^{222}$ Cf. escólio a Paz 246. 
o compromisso de invadir Mégara duas vezes por ano $^{223}$; que se tributassem honras fúnebres a Antemócrito junto às portas triásias ${ }^{224}$, agora chamadas Dípilo.

4. Mas os Megarenses ${ }^{225}$ negaram o assassinato de Antemócrito e atribuíam as culpas a Aspásia e Péricles, citando estes versos célebres e conhecidos de Acarnenses ${ }^{226}$ : "Jovens embriagados ${ }^{227}$ que iam para Mégara, roubaram uma prostituta, Simeta: Os Megarenses excitados pelo desgosto roubam, por sua vez, duas prostitutas de Aspásia." 228

223 Alguns estudiosos, como Gomme (1945-56: II, 93) relacionaram com esta cláusula do decreto as invasóes anuais de Mégara durante os primeiros anos da Guerra do Peloponeso (cf. Tucídides 2.31. 3, 4. 66)

${ }^{224}$ Saída a Noroeste de Atenas, de onde partia a via sagrada para Elêusis e para a planície de Tria.

${ }^{225}$ Plutarco pode estar a referir-se aos historiadores de Mégara que de um modo geral são evocados em grupo (Piccirilli: 1975) ou aos Megarenses coevos do biógrafo (ConNor 1970: 305-308; De Sainte Croix i 1972: 387 ).

${ }^{226}$ Acarnenses 524-527. Aristófanes justifica a origem da Guerra do Peloponeso de modo fantasioso: tendo em consideração a alegada influência de Aspásia sobre Péricles, faz com que a guerra pareça consequência de uma vingançazinha pessoal por causa do rapto de duas cortesâs da companheira do estadista. Essa represália assumiu a forma de decreto, proibindo os Megarenses de praticarem trocas comerciais com Atenas.

${ }^{227} \mathrm{O}$ cótabo era um jogo muito em voga na Grécia entre os séculos VI e IV a.C.: de pé ou deitado, o jogador lançava os restos de vinho do seu copo para uma lâmina de metal equilibrada na ponta de uma barra, que, por sua vez, caía sobre outra lâmina de metal colocada por baixo, produzindo um som. Segundo outros testemunhos, deitavam-se os restos do vinho num recipiente metálico enquanto se pronunciava o nome da amada: se produzisse um som vibrante, era sinal de sorte no amor.

${ }^{228}$ Como já se viu anteriormente (24. 5), Plutarco aceita como histórico o facto de Aspásia ser uma alcoviteira. A explicação que 
31. 1. Ora, não é fácil conhecer-lhe a origem ${ }^{229}$, mas todos, em uníssono, atribuem a Péricles a culpa de não revogar o decreto. Excepto os que dizem que ele não cedeu por grande prudência, com a convicção de que agia pelo melhor, pois julgava aquela exigência uma tentativa de evidenciar a cedência, transigência e uma confissão de fraqueza ${ }^{230}$. Outros dizem que desdenhou dos Lacedemónios por uma certa arrogância, desejo de vencer e demonstração de autoridade.

2. A acusação pior de todas e que tem mais testemunhas ${ }^{231}$ resume-se assim: o escultor Fídias, como atrás se referiu ${ }^{232}$, estava encarregado da execução da estátua, por se ter tornado amigo de Péricles, junto de quem tinha muita influência: arranjou, por isso mesmo, uns tantos inimigos por motivo de inveja. Outros ${ }^{233}$, para experimentarem através dele que tipo de juiz o povo seria para Péricles, convenceram um tal Ménon, um dos

atribuía a Péricles e a Aspásia a responsabilidade da Guerra do Peloponeso surge, segundo Harpocrácion, s. v. A $\sigma \pi \alpha \sigma i \alpha$, em Dúris e Teofrasto.

${ }^{229}$ Pode referir-se à origem do decreto (morte de Antemócrito, ódio de Péricles pelos Megarenses por razóes pessoais de Péricles e Aspásia), como sugere StADTER (1989: 283); ou à guerra, segundo Flacelière (1969: 41), ou SANTONi (1991: 217). Cf. Aristófanes, Acarnenses 528.

${ }^{230}$ Cf. Tucídides 1. 140. 5.

${ }^{231}$ Quando se refere aos testemunhos, provavelmente Plutarco tem em mente Aristófanes, Éforo e os autores que os seguiram.

${ }^{232}$ Per. 13. 14-15.

233 Plutarco menciona não só os inimigos de Péricles que se servem de Fídias para atacar o estadista, mas também os inimigos pessoais do escultor, pois gosta de mostrar os efeitos negativos da inveja sobre os homens influentes. 
colaboradores de Fídias, a apresentar-se como suplicante na ágora, pedindo imunidade para denunciar e acusar o escultor $^{234}$. 3. O povo acolheu o pedido do homem e a acusação foi formalizada na assembleia ${ }^{235}$, mas os roubos não foram provados. É que Fídias, logo desde o princípio, a conselho de Péricles, tinha trabalhado e colocado o ouro na estátua, de tal maneira que fosse possível retirálo todo e demonstrar-lhe o peso, o que Péricles mandou nesse momento os acusadores fazerem ${ }^{236}$. Mas a fama dos seus trabalhos suscitava inveja contra Fídias, em especial porque, quando cinzelou o combate contra as Amazonas no escudo ${ }^{237}$, gravou a sua própria figura, como um velho calvo que levantava uma pedra com ambas as mãos, e incluiu também um belíssimo retrato de Péricles em luta contra as Amazonas ${ }^{238}$. 4. A posição

${ }^{234}$ De acordo com Diodoro Sículo (12. 39. 1), os inimigos de Péricles fizeram com que alguns colaboradores de Fídias se sentassem junto ao altar dos Doze Deuses (no centro da Ágora) para denunciar o roubo que Fídias teria realizado com o conhecimento de Péricles.

${ }^{235}$ Cf. Diodoro Sículo 12. 39. 1-2. Sempre que um escravo quisesse fornecer informaçóes ao Conselho ou à Assembleia sobre um delito, tinha direito a imunidade (adeia), a menos que a acusaçáo não tivesse fundamentos - nesse caso, poderia incorrer em pena de morte. Era a Assembleia que decidia quem seria responsável pelo julgamento: o Tribunal da Helieia ou o Conselho ou a própria Assembleia. No caso de Ménon, tudo leva a crer que seria cúmplice no roubo.

${ }^{236}$ Segundo Tucídides (2. 13), o objectivo inicial de Péricles era utilizar o ouro numa eventual situação de guerra e não defender-se de calúnias.

${ }^{237} \mathrm{O}$ tema do escudo de Atena, na representação criselefantina da deusa no Pártenon, era a batalha de Teseu contra as Amazonas. Sobre a história da batalha, vide Plutarco, Teseu 26-28.

${ }^{238}$ É natural que o escultor sentisse a necessidade de estabelecer uma ligação mais estreita com a sua obra - e, para isso, nada melhor 
da mão, que erguia uma lança diante do rosto de Péricles, estava feita com habilidade, como se quisesse disfarçar a semelhança, que se nota claramente dos dois lados. 5. Fídias por fim foi levado para a prisão ${ }^{239}$ e lá morreu de doença, ou, como dizem alguns, vítima de venenos, preparados pelos inimigos de Péricles para desacreditá-lo ${ }^{240}$. Ao delator Ménon, o povo, por proposta de Glauco,

do que fazer uma espécie de auto-retrato disfarçado. Essa fraqueza, parece, afectou outros artistas, mesmo séculos mais tarde: há, por exemplo, quem afirme que a pessoa retratada por Leonardo da Vinci em Mona Lisa é o próprio pintor. Quanto a Péricles, é talvez difícil saber se a sua representação foi um tributo inocente de Fídias, para imortalizar o político nunca esquecido nos séculos seguintes por causa das suas qualidades morais e de estadista, ou se foi feita a pedido do daquele. $\mathrm{O}$ certo é que Fídias parece ter previsto que a imagem de Péricles eternizada na sua obra suscitaria nos detractores e invejosos do filho de Xantipo o desejo de destruiçáo. Mas, segundo voz corrente na Antiguidade, o escultor aprendera com Péricles a ser previdente, pois a imagem estaria de tal modo posicionada, que retirá-la implicaria a destruição de toda a estátua (cf. e. g. Aristóteles, Sobre o Universo 399b; Valério Máximo 8. 14. 6).

${ }^{239}$ Como nos relata Plutarco, a defesa proposta por Péricles não resultou e Fídias foi condenado. Segundo Diodoro Sículo (12. 39. 1), Fídias foi preso e Péricles acusado de roubar o templo.

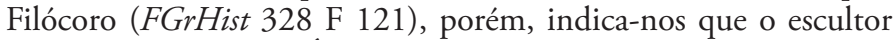
foi desterrado para a Élide onde executou a estátua de Zeus em Olímpia e que pouco depois foi assassinado pelos habitantes, acusado de roubo.

${ }^{240}$ Plutarco não esclarece de que modo a morte de Fídias poderia influenciar a reputação de Péricles. Assim, são três as hipóteses que podemos levantar: ou o estadista era afectado já que ficava desacreditado por não ter conseguido ajudar o amigo; ou porque o aparente suicídio resultava numa confissáo de culpa (logo, Péricles estaria, também ele, implicado); ou ainda visto que o filho de Xantipo acaba por surgir como um indivíduo capaz de matar o cúmplice para se proteger. 
concedeu a isenção de impostos e encarregou os generais de lhe garantirem a segurança ${ }^{241}$.

32. 1. Por essa altura, Aspásia sofreu uma acusação de impiedade ${ }^{242}$, quando o comediógrafo Hermipo ${ }^{243}$ a perseguiu e acusou de receber mulheres livres num lugar onde Péricles pudesse ter encontros com elas ${ }^{244}$. 2. Então Diopites ${ }^{245}$ propôs um decreto (psephisma), segundo o qual quem não acreditasse nas divindades ou ministrasse ensinamentos sobre fenómenos celestes, seria

241 Plutarco deve ter tido acesso a este decreto na colecção epigráfica do macedónio Crátero (cf. Plutarco, Címon 13. 1; Aristides 26. 1-2). Sobre Glauco, não há qualquer outra informação.

${ }^{242}$ Esta informação surgia no diálogo Aspasia de Antístenes Socrático (cf. Aristóteles, Constituição de Atenas 589e; Aristófanes, escólio a Cavaleiros 969; Hermógenes, escólio 7. 165 Walz). A historicidade da acusação de asebeia é negada por MonTUORI (1981: 87-109), porque Aspásia não era cidadã ateniense, logo não podia incorrer neste delito.

${ }^{243}$ Os temas preferidos deste comediógrafo eram a política contemporânea, a paródia de mitos e teorias filosóficas. Péricles, Hipérbolo, e talvez mesmo Alcibíades, sentiram na pele tal incómodo. Segundo Montuori (1981: 92, n. 33), a atribuição da autoria desta acusação a Hermipo coaduna-se com os frequentes ataques feitos a Péricles nas suas comédias. Em Moirai (430 a.C.), ataca violentamente o estadista pela sua estratégia na Guerra do Peloponeso (Per. 33. 8).

${ }^{244}$ Cf. Per. 13. 15, onde se faz uma acusação semelhante contra Fídias.

${ }^{245}$ Adivinho que os comediógrafos (e. g. Aristófanes, Cavaleiros 1085, Vespas 380, Aves 988) ridicularizavam com bastante frequência pelo seu fanatismo, pelo que se compreende que fosse contra uma interpretação racional dos fenómenos naturais. Segundo Aristófanes (escólio a Cavaleiros 1085) foi companheiro de Nícias, o que, por si só, não permite considerá-lo um. Era sobretudo um oportunista que aproveitava as superstiçóes dos Atenienses nas suas intervençóes políticas. 
sujeito a um processo de denúncia pública ${ }^{246}$, dirigindo as suspeitas contra Péricles, por causa de Anaxágoras ${ }^{247}$. 3. $\mathrm{O}$ povo acolhia e aceitava este tipo de ataque, de tal maneira que, aproveitando a ocasião, foi aprovado um decreto por proposta de Dracôntides ${ }^{248}$, exigindo que Péricles apresentasse as contas dos dinheiros públicos ${ }^{249}$

${ }^{246}$ Eisangelia era um tipo de processo reservado para questóes graves e urgentes que não admitiam atrasos.

${ }^{247}$ Cf. Diodoro Sículo (12. 39. 2) e Diógenes Laércio (2. 12 14), que narra quatro versóes do julgamento. Quer a sua data, quer a própria cronologia da vida de Anaxágoras têm sido alvo de acesa controvérsia. Quanto ao primeiro, propóem-se datas entre 450-430 a.C. Para um estudo mais aprofundado deste assunto, vide Mansfeld (1980: 80-84). A melhor solução é admitir com Plutarco que o julgamento de Anaxágoras teve lugar pouco depois do de Fídias. No entanto, em Per. 32. 5, o biógrafo sugere que, com a ajuda de Péricles, Anaxágoras nunca chegou a ir a tribunal, mas muitos estudiosos, como Mansfeld (1980: 82-84), discordam.

${ }^{248}$ Dracôntides e o seu decreto são mencionados apenas por Plutarco. Trata-se provavelmente do mesmo Dracôntides que era epistates da Boulê por altura da aprovação do decreto de Cálcis em 446-445 a.C. e do general que em 433-432 a.C, acompanhou Glauco na expedição a Corcira. Segundo Meinhardt (1957: 61), a fonte de Plutarco em relação a este assunto terá sido a colecção de decretos de Crátero.

249 Segundo Stadter (1989: 301), há uma anedota que seguramente está relacionada com esta situação: Alcibíades, ao ver Péricles preocupado, diz-lhe que não devia pensar na maneira de apresentar as contas, mas sim em como náo fazê-lo. O estratego, seguindo o seu conselho, deu início à guerra (Diodoro Sículo 12. 38. 3-4 e 39. 3; Aristodemo, FGrHist 104 F 16 e Valério Máximo 3. 1). Alguns autores identificam o processo em causa nesta anedota com o de 430 a.C., na sequência do qual Péricles foi destituído (vide Gomme 1945: 187). Frost (1964: 69-72) e Donnay (1968: 19-36) não aceitam esta interpretação, argumentando que a acusação de 430 a.C. dizia respeito a questóes militares (para estes, o processo em causa data de 438-437 a.C.). 
aos prítanes ${ }^{250}$; e que os juízes, com pedras de voto do altar de Atena ${ }^{251}$, decidissem na Acrópole. 4. Hágnon ${ }^{252}$, porém, suprimiu esta cláusula do decreto e propôs que o processo fosse julgado diante de mil e quinhentos juízes ${ }^{253}$, quer se quisesse entender o caso como de roubo e corrupção, quer de malversação.

5. Por Aspásia, Péricles ${ }^{254}$ intercedeu derramando, como diz Ésquines ${ }^{25}$, durante o processo, lágrimas sem conta fazendo apelos aos juízes. Quanto a Anaxágoras,

${ }^{250}$ Os prítanes eram uma comissão de cinquenta elementos de uma tribo que presidiam às reuniôes do conselho e da assembleia, mas apenas num período curto: um décimo do ano, sendo depois substituídos por outra comissão, de outra tribo, até perfazerem as dez existentes.

251 Conferia-se, assim, mais solenidade ao veredicto. O altar mencionado é o de Atena na Acrópole, junto à fachada oriental do Erecteion, onde terminava a procissão das Panateneias.

${ }^{252}$ Filho de um homem de nome Nícias, participou na Guerra de Samos, em 440 a.C., como estratego (Tucídides 1. 117). É comummente aceite como provável fundador de Anfípolis (Tucídides 4. 102. 3, 5. 11. 1). Foi novamente estratego em 431 a.C. (por ocasiāo do cerco de Potideia - cf. Tucídides 2. 58) e em 429 a.C. (Tucídides 2. 95. 3). Participou na assinatura da Paz de Nícias (Tucídides 5. 19. 2, 24. 1) e, em 413 a.C., foi eleito proboulos. Esta sua emenda ao decreto sugere que era apoiante de Péricles.

${ }^{253}$ Consequentemente, o julgamento que de início assumia um carácter extraordinário, tornou-se um processo ordinário, embora o júri fosse mais numeroso do que o habitual.

254 É razoável pensar que agisse como seu defensor, já que Aspásia era meteca. Provavelmente por altura da sua chegada de Mileto, Péricles assumiu as funçóes de seu representante (prostates) e a inerente responsabilidade pela sua conduta moral e civil. Vide MONTUORI (1981: 93).

255 Ateneu (589e) atribui esta notícia a Ésquines, segundo o qual Péricles chorou mais por Aspásia do que nos momentos em que a sua vida ou riqueza correram perigo. 
por receio, enviou-o para fora da cidade ${ }^{256}$. 6. Como, no caso de Fídias, desagradara ao povo, tinha medo de um julgamento; avivou então o fogo ${ }^{257}$ da guerra que estava iminente e que ardia em segredo, esperando dissipar as acusaçôes e diminuir as más vontades; é que, nas empresas grandes e arriscadas, era só nele que a cidade confiava por causa do prestígio e do poder que detinha. São estas as razóes apresentadas para não ter permitido que o povo cedesse aos Lacedemónios - mas a verdade é incerta.

33. 1. Os Lacedemónios, apercebendo-se de que, se o destituíssem, encontrariam os Atenienses mais complacentes para tudo, exortaram-nos a expiar o crime sacrílego de Cílon ${ }^{258}$, no qual, como contou Tucídides ${ }^{259}$, a família materna de Péricles estava envolvida. 2. Mas, para os que tomaram essa iniciativa, o projecto resultou ao contrário: é que em vez de suspeita e calúnia,

${ }^{256}$ Segundo Diodoro Sículo (12.39. 2), Anaxágoras foi acusado de impiedade e, em Plutarco, Nícias 23. 4, diz-se que chegou a estar preso.

${ }^{257}$ Imagem também usada por Aristófanes (Paz 608-610).

${ }^{258}$ Cílon, ateniense nobre e influente, vencedor dos Jogos Olímpicos, casou-se com a filha do tirano de Mégara. Quando, certa vez, consultou o oráculo de Delfos, convenceu-se de que devia tornar-se tirano em Atenas, ocupando a Acrópole. Falhada a tentativa - os Atenienses aperceberam-se e houve um confronto -, Cílon fugiu com o irmáo, mas os outros que o ajudaram foram assassinados, alguns dos quais no interior dos templos, pelo que se considerava que os assassinos tinham cometido sacrilégio contra os deuses. Exortar à exclusão dos que eram amaldiçoados por assassinar suplicantes deve ter parecido uma excelente réplica àquela a que os Atenienses votaram os de Mégara por sacrilégio.

${ }^{259}$ Cf. Tucídides 1. 126-127. 
Péricles obteve ainda mais confiança e prestígio entre os cidadãos, como alguém que os inimigos odeiam e temem particularmente. 3. Por isso, antes de Arquidamo atacar a Ática com os Peloponésios, Péricles declarou aos Atenienses que, se Arquidamo, embora devastando as restantes, poupasse as suas propriedades, ou por laços de hospitalidade que existiam entre eles, ou para dar aos seus inimigos motivos de calúnia, entregaria à cidade a terra e as casas de campo que lhe pertenciam ${ }^{260}$.

4. Os Lacedemónios e seus aliados atacaram a Ática com um grande exército, sob o comando do rei Arquidamo; e, devastando a região, avançaram para Acarnas $^{261}$ onde acamparam, pois julgavam que os Atenienses não o suportariam, mas lutariam contra eles por raiva e orgulho ${ }^{262}$.

5. No entanto, parecia a Péricles perigoso envolver a cidade num combate contra sessenta mil hoplitas do Peloponeso e da Beócia - tantos eram os que participaram na primeira invasão. Acalmou por isso os que, indignados ${ }^{263}$ com os acontecimentos, queriam combater, dizendo que as árvores cortadas e abatidas voltavam a crescer rapidamente, mas que não é fácil recuperar os homens destruídos.

${ }^{260}$ Cf. Tucídides 2. 13. 1.

${ }^{261} \mathrm{Na}$ Primavera de 431 a.C. (cf. Tucídides 2. 18-20; Diodoro Sículo 12. 42). Acarnas era o maior dos demos da Ática e situava-se a sessenta estádios a Norte de Atenas, perto da planície de Triásia. Aristófanes dedicou uma das suas comédias - intitulada Acarnenses - a essa regiáo táo afectada pela guerra.

${ }^{262}$ Este passo é o resumo de Tucídides 2. 19-20. Segundo o historiador, Arquidamo baseava as suas esperanças na juventude dos Atenienses e na atitude dos Acarnenses que náo permitiriam o saque da sua região.

${ }^{263}$ Cf. Tucídides 2. 21. 
6. Deixou de reunir o povo em assembleia ${ }^{264}$, temendo ser forçado a agir contra a sua vontade. Como o piloto de um barco que, quando sopra o vento no alto-mar, depois de pôr tudo em ordem e de esticar as velas, usa a sua técnica, sem se preocupar com as lágrimas dos passageiros que sofrem de náuseas e de medo, também Péricles, depois de ter fechado as portas de Atenas e de, por segurança, a ter protegido toda com guardas, seguiu os seus planos, pouco se inquietando com protestos e descontentamentos ${ }^{265} \cdot 7$. Na verdade, muitos dos amigos pressionaram-no com súplicas e muitos dos inimigos fizeram ameaças e acusações, os coros entoaram cançôes e piadas contra a sua honra, insultando a estratégia que defendia como cobarde e demasiado frouxa para com os inimigos $^{266}$.

${ }^{264}$ A Ecclesia reunia obrigatoriamente pelo menos uma vez por mês. Não temos qualquer indicação que nos diga que os generais tinham o poder de suspender as reunióes regulares da Assembleia. Sabemos, porém, que em situaçóes de emergência podiam convocar uma sessão extraordinária. Sobre a acção de Péricles neste momento de crise, leia-se Tucídides 2. 22.

265 Plutarco aproveita o texto de Tucídides (2. 22) para evidenciar, mais uma vez, a calma e a segurança de Péricles. A comparação platónica (República 488a-e; Górgias 512b-d) com o piloto de um navio mostra as preocupaçóes literárias do biógrafo, que procura adornar a imagem do político ateniense como homem sábio e prudente, que, em situaçóes difíceis, apenas ouve a voz da razão.

${ }^{266}$ Está em causa a controversa estratégia adoptada por Péricles: não ripostar aos ataques terrestres que os inimigos faziam à Ática (o que iria certamente aumentar a destruição), mas contra-atacar por mar (pois o poderio ateniense a este nível era manifestamente reconhecido por todos). Segundo Tucídides, este plano era muito prudente e teria tido hipóteses de sair vencedor, náo fosse o deflagrar da peste em Atenas. Implicava, contudo, que a população assistisse 
8. Já também Cléon ${ }^{267}$ o atacava, aproveitando a ira dos cidadáos contra ele para alcançar a liderança do povo, como mostram estes anapestos da autoria de Hermipo (fr. 47 K.-A.):

"Ó rei dos sátiros, porque não queres empunhar a lança e pronuncias em vez disso extraordinários discursos sobre a guerra? É a alma de Teleto ${ }^{268}$ que se te insinua sob a pele? Enquanto o punhal se afia na pedra de amolar, tu arreganhas os dentes por causa das facadinhas e mordidelas que já sentes do Cléon, essa linguinha cortante.”

34. 1. Péricles não se perturbou com nenhuma dessas investidas e suportava com calma e em silêncio a impopularidade e o ódio. Enviou para o Peloponeso uma frota de cem navios ${ }^{269}$, mas ele próprio não embarcou, antes ficou a vigiar e a controlar a cidade até que os Peloponésios se retirassem.

2. Para acalmar a multidão irritada por causa da guerra, atraiu-a com subsídios e propôs cleruquias. Assim, à destruiçáo e pilhagem dos seus bens sem nada poder fazer. $\mathrm{O}$ povo, talvez por não compreender o alcance desta estratégia, acusa o estratego de cobardia e tolerância em relação aos inimigos.

${ }^{267}$ Um dos principais sucessores de Péricles que quer Aristófanes quer Tucídides atacaram pela demagogia que representava (cf. Aristófanes, Cavaleiros, Vespas, Paz; Tucídides 3.36. 6). Consta que nos princípios da Guerra do Peloponeso (429 a.C.) atacou Péricles (cf. Per. 35. 5) com graves acusaçôes. Foi intransigente na oposiçẫo aos Espartanos e morreu em 422 a.C. na batalha de Anfípolis.

${ }^{268}$ Trata-se de uma personagem conhecida pela cobardia, mas que não se encontra identificada. STADTER (1989: 313) sugere que talvez corresponda a Téleas (cf. Aristófanes, Paz 1008; Aves 167170 e respectivo escólio).

${ }^{269}$ Cf. Tucídides 1. 143. 
depois de expulsar todos os Eginetas, distribuiu a ilha, por tiragem à sorte, entre Atenienses ${ }^{270}$. 3. Alguma consolação resultou também dos danos causados aos inimigos. De facto, os que circum-navegavam o Peloponeso destruíram muitos campos, aldeias e pequenas cidades ${ }^{271}$; enquanto ele próprio se dirigiu por terra para Mégara e a devastou completamente ${ }^{272} \cdot 4$. Assim, era evidente que se os inimigos causavam, por terra, muitos danos aos Atenienses, também sofriam por mar muito graças a eles; nem teriam prolongado tanto a guerra e teriam cedido rapidamente, como desde o príncipio Péricles previra ${ }^{273}$, se a vontade divina não se opusesse secretamente às intençóes humanas ${ }^{274}$.

5. Foi entâo que, pela primeira $v^{275}$, um surto

${ }^{270}$ Segundo Tucídides (2. 27. 1), a razão é estratégica e não pessoal como em Plutarco: é que Egina era muito próxima do Peloponeso e da Ática e, além disso, esta era uma boa forma de acomodar os desalojados que se encontravam nessa situação por causa da invasáo efectuada pelos Espartanos.

${ }^{271}$ Cf. Tucídides 2. 25; Diodoro Sículo 12. 42. 7; Justiniano 3. 7. 5-6.

272 Esta acção vem muito provavelmente na sequência do decreto de Mégara (Per. 30. 3). Ao contrário de Tucídides (2. 31) e de Diodoro Sículo (12. 44. 3), Plutarco esbate o protagonismo do estadista nesta ofensiva, pois não pretende descrever a acçáo de Péricles enquanto estratego durante a Guerra do Peloponeso.

273 Cf. Tucídides 1. 141-144, onde Péricles responde aos argumentos dos Coríntios e analisa as hipóteses de ambas as potências (Atenas e Esparta).

${ }^{274}$ Plutarco aproveita a única referência de Tucídides à divindade (2.64. 1) como elemento que altera a seu prazer os planos humanos. Note-se o paralelo com Fab. 17. 1, onde se diz que Aníbal se desvia de Roma por vontade divina.

$275 \mathrm{O}$ surto surgiu nos começos do Verão de 430 a.C. Por causa do encadeamento do raciocínio que o levou a passar da responsabilidade divina pela derrota ateniense para a peste, Plutarco omitiu determinados acontecimentos cruciais no decurso da guerra (cf. Tucídides 2. 47 e 55; Diodoro 12. 45. 1), nomeadamente a 
de peste os atacou e lhes devastou em pleno vigor a juventude e a força. Atingidos no corpo e no espírito por causa da doença, foi geral o exaspero contra Péricles e a tentativa de o molestar, como os enfermos que deliram fazem ao médico ou ao pai. Deixaram-se persuadir pelos inimigos dele de que a concentração da multidão do campo na cidade originara a doença, pois, no Verão, muitos eram forçados a viver amontoados em casas pequenas e barracas abafadas, numa vida sedentária e ociosa em vez da anterior passada ao ar livre. E o responsável pela situação era quem, por causa da guerra, encurralou a multidão do campo dentro das muralhas sem dar nada que fazer a estes homens, permitindo assim que se empestassem uns aos outros ao aprisioná-los como gado, sem lhes proporcionar nenhuma mudança ou melhoria ${ }^{276}$.

35. 1. No desejo de remediar a situação e de causar algum dano aos inimigos, equipou cento e cinquenta barcos e, depois de embarcar muitos e valentes hoplitas e cavaleiros, preparava-se para partir, causando grande esperança aos cidadãos e medo não pequeno aos inimigos com tamanha força ${ }^{277}$. 2. Quando os navios já estavam prontos e Péricles tinha embarcado na sua

segunda invasão lacedemónia que motivou a concentração da população no interior das muralhas.

${ }^{276}$ Cf. Tucídides 2. 47-54 que Plutarco aqui resume, acrescentando a reacçáo do povo em relaçáo à estratégia de Péricles.

${ }^{277}$ Tucídides 2. 56. 1-2 fala da frota em questão, constituída por cem embarcaçóes fornecidas por Atenas e cinquenta por Quios e Lesbos. Este número, aliado aos quatro mil hoplitas e trezentos cavaleiros, mostra bem a dimensão e potencial de uma tal força. 
própria trirreme, sucedeu que o sol se eclipsou e as trevas apareceram $^{278}$, o que a todos perturbou como um sinal tremendo. Ora Péricles, ao ver o piloto muito assustado e hesitante, pôs-lhe o manto diante dos olhos e, depois de os tapar, perguntou-lhe se não via naquele gesto algo terrível ou um sinal de algo terrível. Como ele respondeu que não, disse-lhe: "Em que é que a outra situação difere desta, a não ser porque o factor que provoca as trevas é maior do que o meu manto?" Pelo menos, este episódio contado nas escolas de filosofia ${ }^{279}$.

3. Então Péricles zarpou, mas parece não ter conseguido nada digno dos preparativos. Cercou a sagrada Epidauro ${ }^{280}$, que lhe despertou a esperança de cair em seu poder, e no entanto falhou por causa da

${ }^{278} \mathrm{O}$ eclipse aqui mencionado teve lugar a 3 de Agosto de 431 a.C., como afirma Tucídides (2. 28).

${ }^{279}$ Cícero (República 1. 16) e Valério Máximo (8. 11, ext. 1) mostram Péricles a explicar o eclipse, sem no entanto relacionarem tal explicação com o momento da partida da expedição. Segundo Stadter (1989: 320), esta pequena incongruência de Plutarco relativamente a outras fontes (já que combina uma expedição que teve lugar em 430 a.C. com um eclipse que, como já vimos, ocorreu em 431 a.C.) resulta do próprio método de composição do biógrafo: embora estivesse a seguir de perto o texto de Tucídides, ao dedicar-se à narrativa da peste, ter-se-á esquecido da referência que o historiador faz ao fenómeno e de imediato passa para o episódio anedótico (de fonte diversa). Assim, pode-se partir do princípio de que lia as notas para organizar o pensamento, mas que nem sempre ia reconfirmar os dados. Esta anedota também lembra a importância que o conhecimento filosófico adquiriu com Anaxágoras.

${ }^{280}$ Epidauro era a segunda cidade da Argólida e forneceu oito navios em Artemísio e dez em Salamina. A sua hostilidade com Argos, primeira cidade da regiáo, fez com que fosse partidária de Esparta. Epidauro era famosa pelo santuário dedicado a Asclépio. O facto de Péricles atacar esta regiáo durante uma situaçáo de peste causa admiração, pois era mais lógico que tentasse pedir ajuda ao deus da medicina. 
doença. $\mathrm{Na}$ verdade, a peste não dizimou apenas os Atenienses, como também os que de algum modo se aproximavam do seu exército ${ }^{281}$. Quando, por causa do sucedido, os Atenienses ficaram furiosos com ele, tentou consolá-los e encorajá-los. 4. Mas não lhes apazigou a cólera nem os dissuadiu enquanto, com votos contra ele na mão e reinvestidos na sua autoridade, lhe não tiraram o comando do exército e lhe não impuseram uma multa em dinheiro; essa soma era inferior a quinze talentos, segundo os que contam por baixo; ou superior a cinquenta, de acordo com os que contam por cima ${ }^{282}$. 5. O acusador que o processou foi Cléon, segundo diz Idomeneu $^{283}$; Símias, segundo Teofrasto ${ }^{284}$; Heraclides Pôntico ${ }^{285}$ indica Lacrátidas.

${ }^{281}$ Neste passo, Plutarco funde dois acontecimentos diferentes: o cerco de Epidauro (Tucídides 2. 56. 4) e o de Potideia (Tucídides 2. 58. 1-2), interrompido por causa da peste que atacou o exército ateniense. A confusão justifica-se mais uma vez pelo método de Plutarco, que se baseia sobretudo na memória.

${ }^{282}$ Sobre este assunto, veja-se Tucídides 2. 65. 3 (em parte parafraseado por Plutarco) e Diodoro Sículo 12. 45. 4. Segundo Platão (Górgias 516a), o facto de o povo afastar Péricles do comando é sinónimo de que o estadista não estava a tornar os cidadãos melhores. De acordo com esta mesma fonte, Péricles era acusado de roubar o erário público.

O processo de deposição chamava-se epicheirotonia. Votava-se, então, no princípio de cada pritania, a actuação dos generais e magistrados. Se essa fosse considerada negativa, o general ou magistrado seria objecto de julgamento: se fosse condenado, o tribunal estabeleceria a pena; se fosse absolvido, reassumiria o seu cargo (cf. Aristóteles, Constituição de Atenas 61. 2).

${ }^{283}$ FGrHist $338 \mathrm{~F} 9$.

${ }^{284} \mathrm{O}$ facto de o nome Símias ser raro em Atenas reforça a autenticidade desta referência. Plutarco também o invoca em Obras Morais 805 c.

${ }^{285}$ Fr. 47 Wehrli. Lacrátidas é referido apenas neste passo. Trata-se 
36. 1. Mas os problemas públicos que o afectavam haviam de cessar rapidamente, pois o povo descarregou a ira contra ele na picada, como um ferrão ${ }^{286}$. Foram então as questóes domésticas que se lhe tornaram penosas: durante a peste, perdera não poucos familiares e as relaçóes em casa vinham sendo, de há muito, perturbadas pela discórdia. 2 . Xantipo, o mais velho dos seus filhos legítimos ${ }^{287}$, que era por natureza gastador e estava casado com uma mulher nova e esbanjadora, filha de Tisandro e neta de Epílico ${ }^{288}$, suportava com dificuldade a economia do pai, que lhe dava pouco e ... com peso e medida. 3. Por isso, dirigiu-se a um amigo e pediu-lhe dinheiro emprestado, como se o fizesse por indicaçáo de Péricles. 4. Mais tarde, quando

provavelmente de um membro de uma família antiga. Vide Davies (1971: 43-47).

286 Introduz-se neste momento uma quebra do relato cronológico - que só será retomado em 37. 1 - para dar a conhecer os problemas pessoais de Péricles com a família. Nesta comparação com o ferrão das abelhas, Plutarco foi provavelmente influenciado por Platão (Fedro 91c) e Aristófanes (Vespas 405 sq., onde os juízes atenienses deliberam como quem distribui ferrôes para punir os que têm comportamentos indignos).

${ }^{287}$ Filho da primeira esposa de Péricles, provavelmente nascido em 457 a.C. Era costume dar ao filho mais velho o nome do avô paterno. Segundo Platão (Menéxeno 94b), Péricles deu aos filhos uma excelente educação no que concerne à arte da cavalaria, música e ginástica, mas não conseguiu fazer deles agathoi. Ésquines Socrático (5.220d) critica-os pelas más companhias.

${ }^{288}$ Membro da família dos Filíades (embora de um ramo diferente do de Milcíades e do de Címon), nasceu cerca do ano 490 a.C. Teve certa importância política, de tal modo que o seu nome chega a aparecer num ostrakon, como candidato ao ostracismo (440 a.C.). Vide MeIGGs \& Lewis (1969: 45-46). A referência à natureza dissipadora das mulheres de boas famílias faz recordar as queixas de Estrepsíades em relação à sua consorte (vide Aristófanes, Nuvens 46-68). 
o amigo pediu ao pai o reembolso, Péricles intentou um processo contra ele $^{289}$. O jovem Xantipo, irritado com o assunto, insultou o pai. Primeiro divulgou, para o meter a ridículo, a forma como geria a casa e as discussóes que mantinha com os sofistas. 5. Durante um pentatlo, por exemplo, alguém ferira involuntariamente com um dardo Epítimo de Farsália ${ }^{290}$ que acabou por morrer - e Péricles, durante um dia inteiro, pôs-se a discutir com Protágoras ${ }^{291}$ quem se devia considerar, numa perspectiva rigorosa, o responsável pelo incidente, se o dardo ${ }^{292}$, se quem o lançou, se os juízes dos jogos.

${ }^{289}$ A anedota, aparentemente, omite pormenores: é provável que o credor tivesse accionado os tribunais para recuperar o dinheiro. Nestas circunstâncias, Péricles terá replicado também com recurso aos tribunais.

290 Segundo a lei ateniense, matar involuntariamente um adversário durante os jogos náo era delito (cf. Aristóteles, Constituição de Atenas 57. 3). Quanto a Epítimo, não é referido em mais nenhuma fonte.

291 Protágoras de Abdera (ca. 490-420 a.C.) foi um dos primeiros sofistas e talvez o mais famoso, conhecido pela célebre máxima "o homem é a medida de todas as coisas". Consta que visitou Atenas algumas vezes e que se tornou amigo de Péricles que lhe confiou a legislação de Túrios (444 a.C.). STADTER (apud PÉREZ JimÉnez 1996: 510), porém, demonstra a incompatibilidade destas personagens e nega a veracidade das anedotas que se referem às discussóes entre ambos, considerando-as um topos retórico na época de Plutarco. Fontes tardias informam-nos de que Protágoras foi julgado e condenado a sair de Atenas (ou mesmo à morte) por asebeia (cf. Diodoro Sículo 9.54). Terá morrido por afogamento a caminho do exílio. Para pormenores a respeito da sua vida e obra, vide Guthrie (1969: 262-269).

${ }^{292}$ A lei ateniense determinava que os animais ou objectos responsáveis pela morte de um homem fossem julgados (cf. Aristóteles, Constituição de Atenas 57. 4) e atirados para fora das fronteiras da Ática, caso fossem considerados culpados. Vide MACDOWELl (1963: 85-89). 
6. Em cima de tudo isto, Estesímbroto ${ }^{293}$ conta que as calúnias sobre a sua própria mulher foram trazidas a público por Xantipo e que, em traços gerais, a divergência com o pai se manteve inalterável por parte do jovem até à morte: é que Xantipo morreu vítima de peste. 7. Péricles perdeu entáo também a irmã e a maioria dos parentes e amigos, além dos seus melhores colaboradores no governo. 8. No entanto, náo cedeu nem abandonou a nobreza e a elevação de alma por causa destas desgraças, nem foi visto a chorar, nem a celebrar os funerais, nem junto do túmulo de nenhum dos seus ${ }^{294}$, até que, por fim, perdeu Páralo ${ }^{295}$, o único sobrevivente dos seus filhos legítimos. 9. Embora abatido por este golpe, esforçou-se por ser fiel ao seu carácter e manter a coragem. Porém, ao colocar a coroa de flores sobre o cadáver, deixou-se vencer pela dor daquela visão, de tal maneira que desatou a gemer e a chorar grande quantidade de lágrimas, o que nunca tinha feito no resto da vida.

37. 1. Entretanto, a cidade experimentava outros generais e oradores para conduzirem a guerra - mas

${ }^{293}$ FGrHist $107 \mathrm{~F} 11$.

294 Para Plutarco, o controlo do sofrimento demonstra a virtude filosófica do autodomínio. A serenidade de Péricles em tais circunstâncias causou a admiração de Valério Máximo (5. 10. ext. 1) que, na ignorância da reacçấo do estadista por altura da morte de Páralo, o apresenta como exemplo de fortaleza e estabelece a relaçáo entre essa característica e a alcunha de Olímpico.

${ }^{295}$ Recebeu o seu nome, como uma das duas trirremes sagradas, do filho de Poséidon, herói de Atenas e protector dos marinheiros. Pouco se sabe a seu respeito. Cf. Platão, Protágoras 315, 319e, 328c. 
nenhum revelou ter a autoridade adequada ou um prestígio que garantisse semelhante liderança. Sentindo a falta de Péricles, chamou-o para a tribuna e para o exército. Este permanecia em casa, desanimado pela dor, mas foi persuadido a regressar por Alcibíades ${ }^{296}$ e por outros amigos. 2. Depois que o povo pediu desculpas da sua ingratidão para com ele, Péricles retomou o governo e foi eleito general ${ }^{297}$. Pediu que fosse revogada a lei sobre os bastardos ${ }^{298}$, que ele próprio promulgara antes, pois não queria deixar o seu nome e linhagem privados de sucessão.

3. Eis as circunstâncias em que a lei surgiu: muito tempo antes, quando Péricles estava no auge da sua carreira política e tinha, como se disse, filhos legítimos,

296 Péricles e Árifron, seu irmão, tornaram-se tutores de Alcibíades após a morte do pai deste, Clínias (batalha de Coroneia, 446 a.C.).

${ }^{297}$ Cf. Tucídides 2. 65. 4; Diodoro Sículo 12. 45. 5. A data da reeleição é controversa: Tucídides diz que tal aconteceu pouco depois do afastamento de Péricles - assim, ou foi convocada uma eleição extraordinária algumas semanas após a destituição, ou os Atenienses aguardaram o escrutínio regular, que teria lugar na Primavera de 429 a.C. (neste caso, Péricles apenas teria reassumido funções em Julho do mesmo ano). Importa salientar que, muito provavelmente, o estratego nunca chegou a pagar a multa determinada (Per. 35. 4).

298 Tucídides e Diodoro Sículo nada dizem a este respeito. Plutarco combina neste relato elementos que não surgem juntos em nenhuma outra fonte: a reeleição de Péricles; o pedido de revogaçáo da lei; a distribuição de cereais vindos do Egipto; a ironia da posição de Péricles; o registo do seu filho como cidadão. Uma descrição táo pormenorizada justifica-se pela necessidade que o biógrafo sentiu de descrever com realismo a situação dramática. Este tema deve ter alimentado as comédias, nomeadamente Demos de Êupolis (Per. 24. 10). 
propôs uma lei segundo a qual apenas eram Atenienses os que tivessem nascido de Atenienses pelas duas partes ${ }^{299}$. 4. Depois, quando o rei do Egipto enviou como presente ao povo quarenta mil medimnos de cereal ${ }^{300}$, era preciso distribuí-lo pelos cidadáos. Por causa daquela lei, muitos processos foram levantados contra bastardos, até então ignorados e desconhecidos. E muitos foram vítimas de acusações caluniosas. Após avaliação, foram discriminados e condenados pouco menos de cinco mil; os que mantiveram a cidadania e foram considerados Atenienses depois do exame perfaziam a soma de catorze mil e quarenta ${ }^{301}$.

5. Embora fosse estranho que uma lei severamente aplicada contra tantos fosse revogada outra vez pelo mesmo que a propôs, a desgraça familiar que sobreveio a Péricles, como se tivesse representado um castigo pela arrogância e orgulho que manifestara, comoveu os

${ }^{299}$ Esta lei data de 451-450 a.C., período do arcontado de Antídoto (cf. Aristóteles, Constituição de Atenas 26. 4). Para mais pormenores sobre as leis atenienses que concernem casamentos entre cidadãos e não cidadãos e também sobre filhos ilegítimos, veja-se Harrison (1968: 61-68). Segundo Aristóteles, a única fonte antiga a avançar com uma explicação, o que conduziu à aprovaçáo desta lei foi a dimensão excessiva do corpo de cidadãos (Constituição de Atenas 26. 4; cf. Política 1278a). Para as várias justificaçóes apresentadas pelos estudiosos modernos, vide STADTER (1989: 334-335).

${ }^{300}$ Um medimno equivale a cerca de 41.5 litros. É provável que se trate da distribuição de cereais mencionada por Filócoro (FGrHist 328 F 119 = escólio a Aristófanes, Vespas 718) e atribuída ao rei egípcio Psamético, não claramente identificado.

301 Também Filócoro (FGrHist 328 F 119) avança dados muito semelhantes aos de Plutarco: 4.760 excluídos e 14.240 reconhecidos. 
Atenienses: estes, considerando que ele sofrera uma pena justa e pedia algo humano, permitiram que inscrevesse o bastardo nos registos da sua fratria e lhe desse o seu próprio nome ${ }^{302}$. 6. Foi esse o filho que mais tarde, depois de vencer os Peloponésios em Arginusas, o povo condenou à morte com os seus co-generais.

38. 1. Parece que foi então que a peste atingiu Péricles. Mas, no caso dele, não se manifestou de forma tão aguda e intensa como nos outros; apresentou-se como uma doença branda e prolongada, com altos e baixos, que lhe esgotava lentamente o corpo e lhe minava a força de espírito.

2. De facto, Teofrasto, na sua obra Ética ${ }^{303}$, depois de se ter questionado sobre se o carácter se transforma conforme as circunstâncias e, se, perturbada pelo sofrimento físico, a excelência degenera, conta que, quando Péricles estava doente, mostrou a um dos amigos que o foi visitar um amuleto ${ }^{304}$ que as mulheres lhe tinham posto ao pescoço, porque a verdade é que

302 A fratria é uma subdivisão da tribo ateniense na qual apenas se podiam inscrever os filhos legítimos que atingissem os dezasseis anos. Este Péricles deve ser fruto do relacionamento do pai com Aspásia e deve ter nascido por volta de 440 a.C. Em 406 a.C., foi um dos generais que participou na batalha de Arginusas (arquipélago constituído por três pequenas ilhas a Sul de Lesbos), no final da qual os Lacedemónios, comandados por Calicrátides, foram derrotados. No entanto, uma tempestade que os apanhou de surpresa impediu que resgatassem e sepultassem os cadáveres. $\mathrm{O}$ povo, furioso, levou a tribunal os seis comandantes que regressaram e condenou-os à morte (cf. Xenofonte, Helénicas 1. 6. 28).

${ }^{303}$ Fr. 463 Fortenbaugh.

${ }^{304}$ Os amuletos eram habitualmente usados por ocasiāo de doenças e febres (cf. Platão, República 426b; Plutarco, Obras Morais 920b). 
só estando muito doente suportaria uma tolice dessas. 3. Quando já estava às portas da morte ${ }^{305}$, os cidadáos mais eminentes e os amigos que tinham sobrevivido, sentados à sua volta, falavam da sua superioridade e poder - quão grande fora! - e recordavam os seus feitos e a quantidade de troféus ${ }^{306}$ : eram nove os que tinha erigido, como general vitorioso, em honra da cidade. 4. Falavam uns com os outros, como se ele já não os escutasse e tivesse perdido a consciência: mas Péricles, perfeitamente consciente, estava atento a tudo o que diziam e levantou a voz para se meter na conversa. Disse que se admirava de os ver louvar e recordar os seus feitos, onde a fortuna tem também parte activa e que já foram executados por muitos generais, e de náo mencionar o mais belo e importante: "É que nenhum Ateniense" disse - "se vestiu de luto por culpa minha ${ }^{307 "}$.

39. 1. Foi, sem dúvida, um homem admirável, não só pela moderação e serenidade que conservou no meio de tantas responsabilidades e de tão grandes animosidades de que foi alvo; mas também pela grandeza

${ }^{305}$ Outono de 429 a.C.

${ }^{306}$ Os troféus eram compostos das armas capturadas e erigiam-se, normalmente, no fim de cada batalha.

${ }^{307}$ Esta mesma anedota surge em Obras Morais 543b. Plutarco explica (Per. 39. 1) que ela alude ao facto de Péricles não ter recorrido à violência nem à guerra civil para obter o poder, como tantos outros. Mas, no contexto em que surge neste passo - logo a seguir à referência aos troféus -, faz lembrar outra qualidade fundamental deste estadista, muito apreciada pelo biógrafo: a asphaleia. É que, apesar das inúmeras batalhas e da Guerra do Peloponeso, nenhuma morte poderia ser atribuída à falta de cuidado ou de sensatez do comandante (cf. 18. 1-3). 
de alma, dado que considerava a mais importante das suas virtudes o facto de, detentor de táo grande poder, nunca ter cedido nem à inveja, nem à ira, nem ter tratado qualquer inimigo como irreconciliável.

2. E parece-me que apenas este facto torna aceitável e explica aquela famosa alcunha pueril e arrogante que lhe deram: só um carácter benévolo e uma vida limpa e imaculada no exercício do poder lhe permitiram ser chamado Olímpico ${ }^{308}$; do mesmo modo que consideramos correcto que, à raça dos deuses, que governa e preside ao universo, só se pode, por natureza, atribuir o bem e não o mal. Demarcamo-nos dos poetas que nos confundem com as suas opiniôes ignorantes e se contradizem nas invençóes que engendram; chamam ao lugar, onde dizem que os deuses vivem, morada segura e tranquila, onde não penetram ventos nem nuvens, que goza, por toda a eternidade, de uma atmosfera agradável e de uma luz puríssima ${ }^{309}$ : e afirmam que assim deve ser a vida porque convém aos bem-aventurados e imortais. Em contrapartida, apresentam os próprios deuses dados a perturbaçóes, hostilidades, ódio e outras paixôes, que nem aos homens de bom-senso são convenientes. 3 . Mas este é talvez assunto para outro estudo.

Os acontecimentos inspiraram aos Atenienses um rápido reconhecimento e uma saudade evidente de Péricles. Aqueles que, enquanto ele vivia, estavam descontentes com o seu poder, porque os obscurecia, depois da sua morte, mal experimentaram outros

${ }^{308}$ Vide Per. 8. 3.

${ }^{309}$ Plutarco deveria ter em mente a descriçáo do Olimpo no canto 6 da Odisseia (vv. 42-45). 
oradores e demagogos, concluíram que nunca existira carácter mais moderado na majestade e mais imponente na condescendência. 4. Aquele tipo de poder contestado, a que antes se chamava monarquia e tirania, revelou-se então como um baluarte salvador do Estado - tal era a corrupção e a quantidade de vícios que ameaçavam os assuntos políticos; esses defeitos, ao debilitá-los e reprimi-los, tinha-os ele mantido ocultos, impedindo deste modo que se tornassem numa realidade incontornável ${ }^{310}$.

${ }^{310}$ Plutarco, como realça STADTER (1989: 350), deixa-se levar pelo entusiasmo nas últimas reflexões sobre a importância política de Péricles e esquece-se de mencionar as indicaçóes relativas à sua sepultura - que seguramente visitou mais do que uma vez. A referência às sepulturas é um topos comum às outras Vidas que escreveu, pelo que só assim se justifica este esquecimento. Segundo Pausânias (1. 28. 2-3), ficava próxima da Academia, junto às de Trasibulo, Cábrias e Fócio (cf. Cícero, Dos Limites Extremos 5. 5). 


\section{VIDA DE FÁBIO MÁXIMO}


(Página deixada propositadamente em branco) 


\section{INTRODUÇÃO}

Ecco Fabio! Nella serenità del cielo la Somma Maestà vuol ch'egli dimori.

Guarda che grande condottiero! Sebbene da tutto il popolo fosse detto Temporeggiatore, tuttavia una grande gloria meritatamente risplende ai cauti consigli.

(Petrarca, Africa 1.371 sqq.)

O fresco de Pietro Vannucci, o Perugino, intitulado "alegoria da Prudência e da Justiça”" (1497)1, não podia ser mais expressivo na representação de Fábio Máximo, o primeiro na prudência, seguindo-se Sócrates e só depois Numa Pompílio. Sob este trio paira a deusa da Prudência.

Do mesmo modo, a prudência ${ }^{2}$ (phronesis) constitui a virtude política e militar que, segundo Plutarco, melhor definiu Fábio Máximo, sendo o traço forte do seu ethos. Esta tendência da natureza (physis), fortalecida pela formação intelectual, foi ampliada e

${ }^{1}$ Trata-se do fresco do Colégio de Cambio (Sala da Audiência) em Perugia, Itália. As figuras são identificadas pelos nomes que aparecem aos pés de cada uma. Da esquerda para a direita: Fábio Máximo, Sócrates e Numa Pompílio; seguem-se Fúrio, Pítaco de Mitilene e Trajano. Numa posição superior, encontram-se as virtudes da Prudência e da Justiça.

${ }^{2}$ Vide os seguintes passos desta Vida 4.4.3; 5.1.4; 17.6.4; 29.2.4. 
posta em prática na comunidade, quando apresentou, em 217 a.C., a célebre táctica militar contra a invasão cartaginesa que consistia em não fazer guerra, deixando que a força de Aníbal se extinguisse por si mesma (2.4) ${ }^{3}$. Esta estratégia cristalizou a memória do general romano, fixando um modo de actuação militar determinante na Segunda Guerra Púnica (218-201 a.C.) que, não tendo expulsado os Cartagineses de Roma, sempre evitou um desastre pior. Tal prática valeu-lhe, na posteridade, o título de cunctator, "contemporizador", conforme o poeta Énio, um dia, reconheceu: Unus Homo nobis cunctando restituit rem (12. 363), "Um só homem, contemporizando, restaurou-nos o Estado" Todavia, apenas em retrospectiva, reconhecemos o sentido heróico destas palavras; na verdade, o momento histórico (kairos) em que Fábio Máximo foi agente não reconheceu o carácter providencial desta táctica militar, tão alheia à agressividade bélica dos Romanos.

Tal como Énio, assim Plutarco o representa: unus homo, isolado, impassível perante as calúnias, conquistando o outro pelo silêncio e pela paciência, qual sapiens estóico. Plutarco evidencia mesmo esta solidáo desde a infância, uma prefiguração do seu carácter e, por extensão, da acção que marcou a sua conduta política e militar. Ainda jovem, são-lhe reconhecidas qualidades éticas como "doçura" (praotes, 3.5), "tranquilidade" (hesychion, 3.5), "silêncio" (siopelon, 3.5), "muita

3 Outras fontes que atestam esta táctica de batalha campal: Políbio 3. 82.4 e Tito Lívio 22. 3.8-9.

${ }^{4}$ Sobre este verso de Énio, vide o recente estudo de ElliotT (2009). 
prudência" (polles men eulabeia, 3.5), que se reflectiam na própria aprendizagem: "a muita prudência que tinha em entregar-se aos prazeres infantis, a lentidáo e a dificuldade com que aprendia as matérias, a complacência e a submissão para com os seus amigos" (1.5). Muitos, porém, desconfiavam de alguma "estupidez e preguiça", e apenas alguns reconheciam, então, a superioridade daquele ethos que despontava (1.5). Com efeito, é nesta dialéctica que se vai construir e definir a figura deste general romano, entre a estima de poucos e o desprezo de muitos. Na República, quando discute a educação dos guardiães, Platão refere também que aqueles que se revelam seres de tempero estável e resistente a qualquer inconstância da vida têm, geralmente, dificuldades na aprendizagem (503c-d) $)^{5}$. Contudo, logo o biógrafo desconstrói estes atributos: "a todos provou que a aparente apatia era, na verdade, impassibilidade, a precaução, prudência e que falta de reacção e agilidade perante qualquer circunstância antes eram constância e firmeza” (1.6).

Assim, a paideia e o contacto com a comunidade permitiriam despertar e optimizar qualidades já detectadas na infância, convertendo em acto o que era potência. $\mathrm{O}$ que não constava na physis, recebeu-o Fábio da comunidade, "treinou o seu corpo para o combate,

5 "Os caracteres sólidos e difíceis de alterar, em quem se podia confiar mais, e que em combate são inabaláveis perante o temor, comportam-se do mesmo modo nos estudos. São parados e aprendem com dificuldade, como se estivessem entorpecidos, cheios de sono e a bocejar, quando têm de executar um trabalho dessa espécie." (503 c-d). Tradução de Rocha Pereira $\left({ }^{10} 2007: 299\right)$. 
como uma arma natural, e o discurso como instrumento de persuasão dirigido ao povo" (1.7). Virtudes como praotes (doçura), pronoia (providência) e eulabeia (prudência), acompanharão sempre este general, sendo invocadas nos momentos mais cruciais do seu percurso, sobretudo a primeira que, apesar de estar geralmente associada à physis, amplia os seus contextos de ocorrência até ao domínio político ${ }^{6}$, como veremos.

Membro da antiga aristocracia romana, pertenceu àquela geração de varóes, como Marcelo (19), por exemplo, que alcançou a maturidade durante a Primeira Guerra Púnica eque se encarregou de liderar Roma durante a crise gerada neste período. Nomeado cinco vezes cônsul, como o seu bisavô, ficou conhecido pelo triunfo sobre os Lígures no primeiro consulado (233 a.C.), exerceu a censura em 230 a.C., conquistando uma autoridade ímpar junto dos seus pares e do povo. Depois de um breve capítulo (1) sobre os antepassados e a educação deste general, Plutarco inicia o relato da Vida quando Fábio Máximo teria por volta de 66 anos $^{7}$, deixando em branco a maior parte dela, dada a escassez de fontes. $\mathrm{O}$ biógrafo inicia a narrativa no ano de 217 a.C. para descrever os sinais que antecederam a batalha do Trasimeno (2.2).

${ }^{6}$ Note-se o último capítulo do proémio de Címon (3), onde Plutarco conclui que ambos os homens (Címon e Luculo) foram calmos (praoi) a nível político, pelo que proporcionaram às suas cidades uma pausa da guerra civil. Martin JR. (1960); Vide De Romilly (1979); Ribeiro Ferreira (2008a) e (2008b).

${ }^{7}$ A data de nascimento de Fábio é incerta. A primeira referência mais segura é a indicação da sua eleição como áugure em 265 a.C., pelo que se fixou, a partir daí, a data de nascimento no ano 283 a.C. Vide F. MünZER (1909: col. 1815). 
Ano de 217 a.C., fórum de Roma. O pretor Pompónio dirige-se ao povo e, friamente, anuncia o desastre do lago Trasimeno: morrera o cônsul Flamínio e, com ele, os melhores dos homens do exército. A crise exigia uma autoridade única que garantisse a segurança. Naquele ano, Fábio contava já dois consulados (233 a.C., 228 a.C.), um triunfo sob os Lígures (233 a.C.) e uma ditadura (ca. 221 a.C. $)^{8}$ e distinguia-o a sabedoria (phronema) e a nobreza de carácter (axioma tou ethous). Fábio é eleito dictator nesse ano (3.6) ${ }^{9}$. A sua acção política começa pelos deuses - o mais belo (kallisten, 4.4) dos inícios - de forma a que o povo recuperasse de novo a confiança (4.4-6). O mesmo se repete, em 215 a.C. quando for eleito cônsul, depois da Batalha de Canas (18.2-4). Com efeito, o seu percurso político foi paralelo ao desempenho de cargos de natureza religiosa: aos 28 anos, foi eleito áugure, e mais tarde, em 216 a.C., é nomeado Pontifex Maximus ${ }^{10}$, funçóes que exerceu até à sua morte (203 a.C.).

Conquistado o povo, Fábio e as tropas vão ao encontro de Aníbal, não para oferecer combate, mas para o seguir ao longe e para esgotar pouco a pouco a sua força e, com o tempo, tirar vantagem da falta de recursos e de

${ }^{8}$ Este dado não consta no relato de Plutarco. A eleição terá ocorrido seguramente entre 221 e 219 a.C. Vide Pérez JimÉneZ (1996: 65 n. 130).

${ }^{9}$ Vide "Introdução Geral", n. 5 e Vida de Fábio Máximo n. 27. ${ }^{10}$ Vide $4.4 ; 4.5 ; 5.1 ; 8.1 ; 17.1 ; 18.2 ; 19.8$. 
tropas $^{11}$. Embora estranha ao típico general romano ${ }^{12}$, esta atitude coaduna-se com os padróes da teoria militar contemporânea, conforme afirma o historiador militar A. Goldsworthy ( $2007: 46)$ : “Fábio, tal como o bom comandante dos manuais militares, evitava a batalha e procurava os meios para mudar as circunstâncias a seu favor.". Com efeito, o general só deve arriscar quando a perspectiva de sucesso for favorável e, após as derrotas romanas de Trébia e Trasimeno, a confiança das tropas de Aníbal era elevadíssima.

Criticado por Minúcio Rufo, o chefe de cavalaria ${ }^{13}$, pelas tropas, pelo Senado e pelo povo, Fábio Máximo recebera já a alcunha de paedagogus de Aníbal. Este, porém, revelava-se confuso e perturbado pois, como

$11 \mathrm{O}$ exército de que Fábio dispunha era precário, sendo constituído por sobreviventes da guerra de Trébia, cuja única experiência de guerra que tinham era a da derrota; as quatro legióes estavam desprovidas de cavalaria, que havia sido destruída no lago Trasimeno e o resto do exército tinha apenas umas semanas de existência. "Seja como for, por muito impressionante que o exército de Fábio pudesse parecer, de modo algum podia equivaler às tropas veteranas de Aníbal”, reconheceu Goldsworthy (22007: 46). É neste contexto que devemos analisar a campanha levada a cabo pelo ditador. Sobre esta táctica fabiana, vide Frontino, Estratagemas (1.3.3; 10) e Polieno, Estratagemas (8.14.1).

${ }^{12}$ Onasandro, filósofo do séc. I d.C., autor de um comentário à República de Platão - hoje perdido - legou-nos o tratado O General, no qual define o perfil do general perfeito (agathos strategos, cap. 2). Este modelo reflecte um estilo de comando tipicamente romano, que persistiu, pelo menos, durante setecentos anos: "O general, quando é recrutado, deve ser útil, afável, diligente, calmo, não tão brando ao ponto de ser desautorizado, não táo severo que ponto de odiado, pelo que nem deve relaxar o exército com favores, nem afastar o exército através do medo." (2. 2-3). Vide também o passo de Estratagemas (1.3.3) de Frontino.

${ }^{13}$ Vide "Introdução Geral", n. 5. 
compreendera o objectivo daquela táctica, procurava, a todo a momento, criar alarmes e emboscadas para o atrair para o combate (5.4). No seio da turbulência de medos, ânsias e precipitaçóes, conservava-se Fábio "fiel e inalterável" (5.5); é ele a personagem tese, o sapiens que conserva a apatheia perante a adversidade, um exemplo prático de uma ética, sempre lida, mas raro experimentada ou de utilidade provada. Com efeito, nada é mais indigno do que ceder ao insulto do mais insensato ou da maioria (5.8):

Não é vergonhoso temer pela pátria e não me parece digno de um homem de tamanho cargo deixar-se influenciar pelas calunias e censuras dos homens, mas antes próprio do escravo que se submete aos insensatos, sobre os quais ele deve ser chefe e mestre.

Pouco depois, porém, Fábio seria vítima da sua própria estratégia. Enganado pelo ardil dos bois de cornos em chamas (6;7.3), a maior parte dos Romanos lança-se em fuga. Ainda assim, Fábio, receando um ataque nocturno, não avançou e, pela manhá, sofre um ataque que ditou a derrota romana (7.1-2) e são feitos vários prisioneiros de ambos os lados. Depois disto, Aníbal, querendo despertar a ira contra Fábio, manda incendiar várias propriedades, poupando apenas aquela do dictator (7.4). Esta, porém, não permaneceria sua por muito mais tempo, pois vendêla-ia para pagar o resgate dos soldados feitos reféns pelos Cartagineses, depois de o Senado se ter recusado a garantir a quantia que ele acordara com Aníbal (7.7). 
Constituiu este o primeiro acto de "doçura" (praotes) desta biografia, isto é, a manifestação pública de um traço da physis, que se irá revelar em mais quatro momentos (12.3; 18.4; 20.2; 20.5). O maior oponente público era o seu chefe de cavalaria, Minúcio Rufo que, encorajado pelos últimos acontecimentos, procurava a todos convencer da necessidade de um ataque directo. Certa vez, quando metade do exército de Aníbal tinha saído em busca de provisôes, ficando, por isso, mais vulnerável, Minúcio, com alguns homens, ataca de surpresa e faz algumas baixas. A Roma chega a notícia de algo mais grandioso do que realmente acontecera; a ira do povo e do Senado contra Fábio aumenta e evidencia-se numa nova resolução, inédita $^{14}$ : a nomeação de Minúcio como co-ditador (9.3).

${ }^{14}$ Esta resolução é inédita na história da república romana, pois a magistratura dictatura concedia ao magistrado o poder absoluto e, segundo algumas fontes (Tito Lívio 2.18.8/ 3.20.8; Dionísio de Halicarnasso, Antiguidades Romanas 10.24.2) sem direito a provocatio, isto é, o direito que assiste qualquer cidadáo romano de chamar (prouocare) o povo para se opor a uma coacção ou morte imposta pelo magistrado. Este ius prouocationis aplicava-se somente a cidadãos e estrangeiros, não abrangendo a esfera militar. Contudo, embora fosse uma prática corrente, nenhum ditador terá, de facto, abolido esta lei, conforme sugerem as fontes (Lintotт 2003: 111). Deste modo, o dictator não teria paralelo no imperium (Fab. 4.3), caso contrário não poderia cumprir a função primeira desta magistratura: o comando unificado do exército. Note-se que o chefe de cavalaria (magister equitum), apenas tinha direito a seis lictores com fasces, enquanto o dictator possuía vinte e quatro. Assim, esta equiparação de Minúcio Rufo ao cargo de dictator de Fábio partiu da população que temia que Fábio usasse de um direito que lhe assistia na qualidade de ditador: "como o ditador tinha o direito de prender e condenar à morte sem julgamento prévio, pensavam que o espírito de Fábio, agora sem a sua mansidão, se tornaria inflexível e implacável" (Fab. 9.1). Sem o direito de provocar o povo para uma sedição contra uma eventual condenação, Minúcio contou com o apoio de Metílio (Fab. 
Impopular e com menos poder, Fábio passa a comandar duas legióes, o seu colega outras duas e o acampamento divide-se. Pouco tempo depois, Fábio tem que se deslocar a Roma para oferecer sacrifícios aos deuses e Minúcio aproveita a ocasião para atacar Aníbal (11). O desastre desta ofensiva só não foi maior, porque Fábio acorreu ao local para salvar o colega Minúcio. Constituiu este acto o segundo momento de praotes que, no enquadramento moral dos Romanos, encontra expressão no valor da clementia, "a mansidão e a misericórdia, a capacidade de dar e de perdoar" ${ }^{15} \mathrm{e}$ no interesse da res publica, que é superior a qualquer diferença. Comovido por este acto, Minúcio, com a sua parte do exército, a ele se dirige para o aclamar como "pai", reconhecendo que tem mais capacidade para obedecer do que para liderar (13). Esta cena é plena de dramatismo, pois Plutarco descreve todos os movimentos dos intervenientes como de didascálias se tratassem (13.5-6; 13.9), atribuindo duas falas extensas a Minúcio (13.2-4; 13.7). O pathos atinge o clímax no momento em que ambos se abraçam e beijam, à semelhança dos próprios soldados ${ }^{16}$. Esta

9.2) que, na qualidade de tribuno da plebe - a única magistratura que não perde o poder durante a dictatura - decretou, por votação, que o cargo de general (magister equitum) se equiparava ao de chefe e actuava na guerra com a mesma autoridade que o ditador (rogatio Metilia). A propósito desta lei, vide Políbio 3.103.3-5, Cornélio Nepos, Aníbal 5.3 e Tito Lívio 22.25-26. Note-se que Metílio era, segundo Plutarco, parente de Minúcio (Fab. 7.5).

${ }^{15}$ Salústio, Catilina 54, em traduçáo de Rocha Pereira (52005: 103). Sobre este valor romano, vide Rocha Pereira (32002: 368-73).

${ }^{16} \mathrm{O}$ pormenor da descrição aprofunda, com efeito, o pathos e a psicologia das personagens. Encontra-se também em Tito Lívio 
cena de reconciliação inspirou artistas como Peter Paul Rubens $^{17}$ e Francesco de Siena ${ }^{18}$, que ilustrou também outras sequências narrativas da vida do general romano.

Seis meses depois ${ }^{19}$, Fábio termina o seu mandato e regressa a Roma. No ano seguinte (216 a.C.), um desastre maior haveria de sobrevir: a derrota de Canas ${ }^{20}$. Numa nova crise política e Fábio Máximo é reeleito para o quarto consulado em 214 a.C. O seu colega é Marcelo ${ }^{21}$, arrojado e agressivo em combate e, com Fábio, fazia o par perfeito: um era o escudo e o outro a espada ${ }^{22}$ (19.4).

(22. 30, 6), embora sem a carga emotiva e patética que Plutarco lhe confere.

${ }^{17}$ Von Alten (1933).

${ }^{18}$ Vide as reproduçôes que constam em GuerRini (1991b). Eis as sequências que foram representadas: a eleição como ditador (FAB. MaX. Ditactor Designiatus [sic]), o sacrifício aos deuses (Fab. Sacrificium), lealdade para com Aníbal (Fab. Fides Erga Hannibalem), a astúcia no confronto com Aníbal (Fab. Astutia in Hannibalem), o socorro a Minúcio (Fab. Minutio Succurso PENOS fUGAT), a reconciliação com Minúcio (Fab. Minutius Patrem appellat), a reconquista de Tarento (Fab. Tarentum RECUPERAT), em honra da memória do filho falecido (FABiUs FILIUM CONSULEM HONORAT). Esta colecção encontra-se no Palácio Abadia de Grottaferrata (Lácio, Roma).

${ }^{19}$ Vide "Introdução Geral", n. 5.

${ }^{20}$ Sobre a disposição campal das tropas nesta batalha, vide Cambell (2004: 109).

${ }^{21}$ Marco Cláudio Marcelo, plebeu, fora cônsul em 222 a.C. e pretor em 224 a.C. Quando era mais jovem, combatera na Sicília durante a Primeira Guerra Púnica, e conseguiu várias condecoraçōes por actos individuais de heroísmo, uma corona ciuica, a maior condecoração de Roma, concedida pelo seu irmáo Otacílio, por aquele lhe ter salvo a vida.

${ }^{22}$ Posidónio ( $F G r H 87 \mathrm{~F} 42$ ). Sobre esta dupla de generais, afirma GOLDSWORTHY (2007: 54): "Uma significativa experiência em campanhas passadas, aliada à capacidade natural, permitiu 
A acção de Fábio era como um rio que "fluía sem ruído e pouco a pouco e consumia continuamente as suas bordas" (19.5), enquanto a de Marcelo era como um "rio violento". Não conquistaram uma derrota definitiva aos Cartagineses, mas conseguiram evitar um desastre pior. Ambos os generais são reeleitos para um quinto consulado em 209 a.C., o último.

Nesta altura, em plena invasão cartaginesa, quando se torna mais premente resolver a questáo do afastamento das cidades e da revolta dos aliados, Fábio é chamado a resolver dois casos de indisciplina no exército. $\mathrm{O}$ primeiro trata-se de um soldado marso, de grande mérito militar, que tentara desencadear um revolta contra Fábio; este, em vez de o repreender, ofereceu-lhe um cavalo de guerra e outros prémios como reconhecimento do seu valor. No outro caso, um soldado lucano, também ele muito corajoso, ausentava-se do acampamento para ir pernoitar com uma mulher que morava longe. Nisto, Fábio mandou vir a mulher para o acampamento de forma a que ele não tivesse que fazer mais caminhadas e, por isso, diminuir o seu contributo ao exército. Estas acçóes constituem também expressão de praotes, pois aquele que comanda os homens deve usar da benevolência e da mansidão para conquistar lealdade de quem mais precisa (20.4), algo peculiar à conduta do herói, como refere J. Ribeiro Ferreira (2008b: 116): "Em Plutarco encontramos frequentes vezes sublinhada a ideia de que a humanidade do herói para com os

a Marcelo e a Fábio distinguirem-se da maioria dos restantes comandantes romanos seus contemporâneos e tornou o seu estilo de liderança em algo bastante próximo do helenístico". 
vencidos ou os subordinados é muitas vezes mais eficaz do que a violência e a dureza." ${ }^{23}$

Fábio, já de idade avançada, recupera Tarento à traição (21-24). É a partir deste momento que se dá a chamada "metamorfose" 24 ética que inicia a uma inesperada fase de insolência que ensombra a constância deste percurso ético. Em primeiro lugar, ainda em Tarento, assassina os cidadãos brútios mais importantes para que não se soubesse da traição (22.5), e, por isto, "recebeu a acusação de deslealdade e crueldade"; levou consigo o património artístico da cidade, nomeadamente a estátua colossal de Hércules que colocou no Capitólio, erigindo, ao lado, uma estátua equestre de si próprio em bronze (22.7-8), celebrando o triunfo da tomada de Tarento, "com mais pompa que o primeiro" (23.2).

Neste ponto, a perspectiva de Plutarco torna-se ambivalente pois, apesar destes factos, parece forçado a continuar a mesma linha luminosa de constância e ponderação que fora perspectivada no início e que vinha sendo confirmada pelo percurso de vida. Com efeito, neste momento já não reconhecemos o mesmo "cordeirinho" (ovicula, 1.4) da infância ou o político de oratória transparente e moderada (1.8). Contudo, esta tendência já antes se manifestara de forma pontual: depois da eleição de Fábio como dictator, o primeiro pedido que fez ao Senado foi o de poder ir a cavalo

${ }^{23}$ Cf. Marcelo 19. 2-6, 12; Aristides 23.1; Cimon 6.2; Flaminio 2.5, 5.7 .

${ }^{24}$ Vide Rebuffat, M. R. (1978), "Métamorphose de Fabius Cunctator: Thomas Diaforius", in Colloques d'Histoire et Historiographie, Paris, pp. 335-sqq. apud Guerrini (1991a: 256). 
durante as expediçóes militares, algo proibido por ser mais uma marca de ostentação de poder de alguém que já detinha o poder absoluto (4.1-2), bem como o facto de querer mostrar a grandeza do cargo da ditadura ao desfilar em público com vinte e quatro lictores reunidos à sua volta, de forma a conquistar a obediência dos cidadãos (4.3).

Nesta medida, a tendência mais evidenciada na fase final da sua vida não é inédita, mas já se encontrava em potência, na physis, mas refreada pela paideia e pela vivência em comunidade durante a sua fase mais activa. Esta fase de decadência ética torna-se ainda mais óbvia pela atribuição de qualidades do campo semântico da senilidade, como "velhice" (geras), "debilidade" (astheneia 24.1), "intratável" (dyskolos), "invejoso" (baskanos), "cobarde" (atolmos) e "pessimista" (dyselpis, 26.3), "antiquado" (arcaios), "obsoleto" (presbytikos, 25.1) adjectivos que caracterizam a sua táctica de batalha campal. Longe do tom encomiástico, estas qualidades apresentam um carácter disfórico, um estado que é uma consequência da degenerescência natural e, como tal, já distante das exigências políticas e militares do presente.

Aberta esta crise na constância deste ethos, Plutarco intercala dois episódios que, de certa forma, anunciam o final da carreira política de Fábio como prefiguraçóes. O primeiro tem lugar quando o seu filho é eleito cônsul e surge uma menção à velhice do pai (24.1); num outro momento, Plutarco recorda um episódio do bisavô de Fábio, quando regressava com o seu filho da guerra no desfile triunfal. Aquele seguia-o a cavalo com os outros 
elementos da comitiva e mostrava-se orgulhoso, pois estava subordinado à lei e ao magistrado, o seu filho (24.5). Além do elogio das tradiçóes militares e de enaltecer o sentido aristocrático da família, o biógrafo estabelece este paralelo entre Q. Fábio Máximo Ruliano e Fábio para demonstrar que a finitude do exercício político é inevitável e necessária à comunidade.

Depois destes momentos, Plutarco dedica os capítulos seguintes (25-27) à última fase da vida do general, tempo de decadência política, que contrasta com a audácia de Cipião ${ }^{25}$. Fábio cedera, enfim, aos imperativos da natureza humana: agora, cego pelo desejo de glória, temia ser ultrapassado por um general mais jovem e brilhante que pusesse fim à guerra contra Aníbal, algo nunca conquistado por ele. Pela primeira vez, deu primazia ao interesse privado ( $\dot{\varepsilon} \alpha v \tau$ òv, 25.3) em detrimento da res publica; e expulsar os Cartagineses e deslocar a guerra para o norte de África. Pela primeira vez, a comparação pendia negativamente para Fábio, ao contrário do que antes sucedera nos paralelos com Gaio Flamínio (2.4), Minúcio Rufo (9) e Terêncio Varrão (14).

Esta angústia do inesperado desencadeou, em Fábio, uma série de comportamentos contrários à apatheia que antes o caracterizava e que se afiguravam ridículos no palco político. $\mathrm{O}$ antigo ditador tentava agora travar os planos de Cipiáo: infundia todo o tipo de medos na cidade, acusando Cipião de insensatez e

${ }^{25}$ Plutarco valorizou especialmente esta vida, pois teria sido um dos elementos do primeiro par de Vidas, Cipião-Epaminondas, hoje perdido. Vide Crespo ( $\left.{ }^{4} 2007: 314\right)$. 
inexperiência, encarregou o colega Crasso de demover o colega de atacar Aníbal e impedia ainda os jovens que se queriam alistar na sua campanha. Mais tarde, quando começaram a chegar notícias das façanhas de Cipião, exigiu o envio de um substituto para Cipião, alegando que é difícil que a mesma pessoa seja sempre afortunada. E nem depois de Aníbal ter abandonado Itália, deixou de o criticar ou de incutir o receio e a desconfiança nos cidadáos $(25.3 ; 26)$, algo tão diverso da acção de Fábio enquanto ditador (4.4). Nesta fase, repete-se a mesma situação que ocorrera com Minúcio Rufo, quando Fábio o advertiu de que "o seu combate não era contra Fábio, mas sim contra Aníbal” (10.7). Com efeito, também agora o seu inimigo deixara de ser Aníbal para passar a ser Cipião, já que era contra ele que Fábio se pronunciava no Senado, em vez de encontrar soluçóes conjuntas para vencer o poderoso exército cartaginês. Assim, os verdadeiros inimigos parecem ser a ambiçáo, a necessidade de glória pessoal e reconhecimento público, pois determinaram as acçôes de Minúcio Rufo, Terêncio Varrão e agora, nesta última fase, até a de Fábio Máximo; o drama desta Vida centra-se mais na densidade psicológica destas lutas internas, do que no combate contra Aníbal, cujo retrato é sobretudo encomiástico.

Nesta medida, o julgamento do biógrafo torna-se já artificial, pois se, por um lado, há a tendência para completar idealmente este perfil, por outro náo pode corrigir a história e os traços negativos também têm de ser "contemplados". Tal oscilação é evidente quando 
procura justificar este comportamento com a prudência habitual - "é provável que o propósito inicial de se opor a estes planos se tenha devido mais à segurança e à prudência” (25.3) -, mas logo acrescenta que foi, afinal, "arrastado por uma certa ambição e rivalidade de modo a impedir o engrandecimento de Cipião" (25.3). Concluiu, portanto, que se tratava de uma política de Fábio que "estava em conformidade com a sua natureza [heautou physin]" (26.2). Com efeito, sendo um traço excessivo da sua essência, converteu-se numa afecção da qual ficou prisioneiro. Podemos, assim, comparar esta última fase de Fábio com as figuras com que ele se confrontou ao longo do seu percurso político: Gaio Flamínio (2.3.3; 3.3.6), Minúcio Rufo (10.4.1) e Terêncio Varrão (14.2), que personificaram eles mesmos estas afecçóes, das quais Fábio sempre se demarcou por apresentar uma atitude contrária à guerra. Na verdade, os confrontos entre Fábio e a figura de outro estadista, um sensato e um ambicioso num eixo de superioridade e inferioridade, constitui um eco platónico da forma de governo timocrática, uma mistura de bem e mal (República 548c7). Note-se que ambas as expressóes assinaladas apresentam os mesmos termos gregos: philotimia e philonikia.

Contudo, tornou-a uma questão pessoal e foi mais longe arrastado por uma certa ambição e sede de vencer, de modo a impedir o engrandecimento de Cipiāo.

Fábio Máximo 25. 3. 4 
- A forma de governo a que te referes é uma mistura completa, de bem e de mal.

- É uma mistura, efectivamente - disse eu-Mas há uma caracteristica evidente, devido a ser governada por um exaltado, que é a ambição e o gosto de honrarias ${ }^{26}$.

Platão, República 548c7

Tal ambivalência teve lugar durante a ditadura “dupla” em 217 a.C. de Fábio e Minúcio Rufo e, em 216 a.C., com Gaio Flamínio e Terêncio Varrão, aquando da derrota de Canas. Neste caso, o confronto entre Fábio e Cipião só engrandece este último; o primeiro, outrora referência de prudência, desloca-se para um ponto diametralmente oposto.

Só a geração mais jovem, liderada por Cipião, conquistou a vitória contra os Cartagineses na batalha de Zama, mas Fábio já não viveu para assistir a esta glória. A descrição do funeral de Fábio é outro dos momentos de pathos desta Vita. O título de pater que Minúcio lhe atribuíra é recuperado para completar o clímax da cena que apresenta o desfecho ideal de uma vida exemplar do ponto de vista ético e filosófico: "cada particular contribuiu com a mais pequena das moedas, não por falta de ajuda por causa da sua pobreza, mas porque o povo o enterrou como a um pai." (27.3).

Este final demonstra que a fase de decadência de Fábio foi completamente superada e, como tal, recebeu, na morte, as honras que merecia enquanto pai. Assim

${ }^{26}$ Tradução de Rocha Pereira ('2001: 369). 
se fixou a memória de um homem prudente, religioso, dotado de uma perspicácia invulgar e com um profundo sentido de res publica, apesar de, no final da vida, ter revelado excessos contrários a esses ideais. Com efeito, denunciar os defeitos em paralelo com as virtudes estava já previsto no programa moral das Vidas, pois como o biógrafo afirmou no proémio da Vida de Címon (2.3). Assim, do mesmo modo que o pintor náo pode enfatizar os traços negativos, pois produz uma imagem vergonhosa (aischran opsin), também não os pode omitir, sob pena de parecer inverosímil (anomoian), pois também para o biógrafo é pouco provável apresentar um percurso de vida irrepreensível ${ }^{27}$.

Desta Vita, salientamos o valor da praotes (doçura) que, em conjunto com a pronoia (providência), caracteriza F. Máximo a nível físico (1.5; 17.7), moral (1.4) e político (20.4), manifestando-se na infância com os colegas, alargando-se mais tarde à esfera pública, tendo ainda marcado a sua conduta política e a intervenção na Segunda Guerra Púnica. Trata-se de um ideal de vida essencialmente grego, que tudo comanda, que exprime tolerância e indulgência e que na obra de Plutarco atinge o seu apogeu, como sublinhou J. De Romilly (1979: 275): "Le vocabulaire de la douceur est, chez lui, plus riche et plus complet que chez aucun autre écrivain." A praotes consiste assim numa resistência interior à violência e aos prazeres ${ }^{28}$, pelo que entra plenamente em

${ }^{27}$ Vide, a propósito, STADTer (1997).

${ }^{28}$ Cf. Bruto 1.3. Esta virtude é também descrita por Aristóteles (Ética a Nicómaco 1126a1): "Porque o gentil [praos] quer permanecer imperturbável e não quer ser levado pela emoçáo, e 
diálogo com outra tendência deste general já referida, a apatheia, traço do sapiens estóico.

A praotes, à luz da ética do povo romano, aproximase da clementia que consiste na mansidão, misericórdia, na capacidade de dar e perdoar ${ }^{29}$, mas esta é menos ampla por se tratar de uma prática da esfera política, ao contrário da grega, que começa por ser um traço da physis, alargando-se ao campo político e social. Os actos referidos como expressão de praotes seriam designados por outros conceitos que reflectem valores específicos romanos. Por exemplo, o facto de Fábio ter cumprido o compromisso que firmou com Aníbal, contra a vontade do Senado e tendo, para isso, que vender a sua propriedade, trata-se de um acto de fides, a fidelidade a um juramento; o gesto de Minúcio Rufo que aclama Fábio de "pai", reconhecendo a sua imprudência face à grandeza de espírito do general, pode ser visto como uma manifestação de pietas, um sentimento de obrigação para com aqueles a quem se tem uma ligação familiar, com pais e parentes, ou social, como outros membros da comunidade ${ }^{30}$. Expressão deste mesmo valor é também a relação de Fábio com os deuses, que manifestava publicamente uma relação de temor para com a divindade $(4.4 ; 8.1 ; 18,2)$, tendo desempenhado cargos religiosos, como vimos.

apenas o sentido orientador lhe poderá prescrever as situaçóes em que deve irritar-se e durante quanto tempo. Ou seja, o gentil parece pecar mais por defeito, porque não é do tipo vingativo mas mais do género que perdoa." Tradução de CAEIro (2004: 98). Vide ainda Ribeiro Ferreira (2008b: 112).

${ }^{29}$ Vide n. 15 deste estudo.

${ }^{30}$ A este respeito, vide Rocha Pereira ( ${ }^{3} 2002$ : 338-9). 
Com efeito, o acto de receber, em festa, Terêncio Varráo que tinha desaparecido depois do desastre de Canas (18.4), também pode ser entendido como um acto de clementia: "elogiaram-no por não ter renunciado à cidade depois de tamanho infortúnio e por estar ali presente para desempenhar o seu cargo, velar pelas leis dos cidadãos" (18.5). O ponto de vista do biógrafo é grego, pelo que faz corresponder estas acçóes a conceitos existentes na cultura helénica, permitindo assim uniformizar o valor programático inerente a cada par de Vidas - neste caso, a praotes.

Constatámos, ao longo desta Vida, que certos momentos são invulgarmente extensos, recorrendo ao biógrafo ao uso do discurso directo conferindo verosimilhança à cena descrita, de forma a conquistar a empatia do ouvinte e garantir a adesão ao modelo ético apresentado. A inclusão de certos momentos aparentemente sem importância para a economia narrativa $(12.2 ; 5.7-8 ; 15.3)$ cumpre, afinal, outro objectivo: iluminar e fixar a memória de uma figura ${ }^{31}$, como esclareceu Plutarco no início da Vida de Alexandre (1. 1-2):

(...) nem sequer é nos acontecimentos mais espectaculares que reside especialmente a demonstração da virtude e do

${ }^{31}$ A verdade é que quase toda a narrativa está concentrada entre a Batalha do lago Trasimeno (217 a.C.) e a de Canas (216 a.C.), pois aí se localizam as descriçôes mais completas e dramatizadas desta $V i d a$, tendo como tema principal, o confronto com Aníbal. Depois de Canas, a narrativa só retoma o ritmo mais lento e descritivo aquando da tomada de Tarento (214 a.C.), o último momento de expressão heróica deste general. 
vicio; pelo contrário, muitas vezes um pequeno gesto, uma palavra ou uma brincadeira reflectem melhor o carácter do que os combates com baixas incontáveis (... $)^{32}$

Na verdade, "os combates com baixas incontáveis" constituem o objecto de histórias mais pormenorizadas (16.6; 21.5), fontes para a construção das Vidas, neste caso as obras de Tito Lívio, Políbio ou a História de Posidónio de Apameia (que não chegou até nós). Em relação aos episódios ocorridos no final do século III, por altura da derrota de Canas (216 a.C.) terá recorrido aos testemunhos de Díon Cássio, à Guerra de Aníbal de Apiano, ao [anónimo] Sobre os varóes ilustres, a Valério Máximo, e outros autores do século II e I, como os historiadores Célio Antípatro e Valério Ântias ${ }^{33}$. Assim, enquanto estas fontes se ocupam da história de um povo em geral, as Vidas de Plutarco são expressão do fascínio pelo particular, a vida de um homem, ainda que muitas vezes se confunda com a história do seu povo. Como ele mesmo afirma "nós não escrevemos histórias [historias] mas sim biografias [bious]” (Alexandre 1.2).

A experiência de guerra seria algo familiar aos ouvintes e leitores das Vidas, pelo que o comportamento do político teria uma função didáctica e um efeito performativo, pois apresenta a história de grandes homens em acção, conforme lembra P. A. Stadter (1997: 69): "Plutarch's biographies respond to this deeply felt need among the elite of the empire". Esta

${ }^{32}$ Tradução de LEÃo (2008: 103).

${ }^{33}$ Vide Pérez Jiménez (1996: 37). 
premência de exempla era já sentida nos escritos de ética romana, como no De Officiis ${ }^{34}$ (3.19) de Cícero, que representa já um estádio significativo do pensamento ético e permite explicar a decisão de Plutarco de escrever biografias, algo também expresso por Séneca ${ }^{35}$. Assim, estas Vitae combinam história e filosofia ética, de forma a demonstrar a utilidade dos princípios filosóficos, que, por si só, não são suficientes. Com efeito, como nota Stadter (1997: 67), as circunstâncias reais de uma acção afectam a avaliação ética da mesma: por exemplo, matar um homem é um princípio errado, mas pode não ser reprovável se se tratar de um tirano.

Com efeito, para o mesmo fim fora criada a Ética a Nicómaco de Aristóteles, de forma a fixar padróes de conduta, analisando o problema ético face ao seu horizonte prático, onde as possibilidades de variação se multiplicam consoante as circunstâncias, pois "a excelência ética constitui-se, portanto, em vista de fenómenos de prazer e de sofrimento (1104b3)"36.

Nesta medida, a biografia plutarquiana adequa-se a um determinado programa moral previamente delineado, partindo já de um referencial, Péricles, com o qual o general romano se assemelha ou diverge. Assim, a história de uma

${ }^{34}$ Vide Stadter (1997: 67 sqq.).

${ }^{35}$ Em Cartas a Lucílio 94, Séneca expóe, com clareza, esta questáo: "O problema da parenética divide-se, portanto, em duas questôes: ela é útil ou inútil? É por si só capaz de formar o homem de bem ou não? Em suma, ela é supérflua, ou, pelo contrário, torna supérfluo todo o resto da filosofia?”. Tradução de Campos ( $22004:$ 480).Vide também STAdTer (1997: 69).

36 Tradução de Caeiro (2004: 46). 
vida é moldada para se ajustar a um determinado conjunto de valores políticos e éticos.

Do mesmo modo, Fábio suportou os seus ultrajes, impassivelmente (apathos) e com mansidão, de forma a servir de exemplo (apodeixin) aos filósofos que sustentam que não é possível nem insultar, nem desonrar o homem bom e virtuoso (10.2)

O biografado torna-se assim um actor moral, cujo comportamento é apresentado com vista a confirmar dogmata, que carecem de exemplos práticos que reflictam a sua utilidade ${ }^{37}$. Assim, a vida deste general parece construída para confirmar o axioma da apatheia ${ }^{38}$, a impassibilidade face aos afectos da natureza humana. Com efeito, não podemos perder de vista o intuito didáctico da sua obra, pois Plutarco era sobretudo um grande divulgador da filosofia.

Só o tempo devolveu justiça e actualidade a esta figura. Além de ter conhecido alguns florescimentos na posteridade, com referências pontuais a nível literário ${ }^{39}$, no domínio da $\operatorname{arte}^{40}$, a sua táctica de batalha campal

${ }^{37}$ STADTER (1997: 70): "A few examples of Plutarch's use of history to create moral portraits will help us appreciate his ability to highlight the moral dimensions of political action, and allow his readers to have that bonorum uirorum conversatio urged by Seneca".

38 Além da ocorrência acima mencionada, há outro registo do mesmo termo em 1.6.2, quando tratava a sua caracterização espiritual na infância: "a todos provou que a aparente inacção era, na verdade, impassibilidade [apatheian]".

${ }^{39}$ Uma antologia de textos sobre Fábio consta em SANTONI (1991: 287-99).

${ }^{40}$ Vide nota 18 deste estudo. 
teve também muita repercussão na teoria militar contemporânea, como vem confirmar Goldsworthy (22007: 46): “(...) o ditador agia correctamente. Muita desta literatura cita o exemplo de Fábio na abordagem das circunstâncias em que um chefe militar deve travar abertamente uma batalha."

Contudo, nenhuma recepção se pode equiparar àquela que teve lugar no final do século XIX, no Reino Unido e na Irlanda. Recuperada no âmbito da filosofia política, a estratégia militar de Fábio actualizou-se numa nova dimensão, com a fundação, em 1884, da Sociedade Fabiana $^{41}$. A criação deste movimento intelectual é atribuída a Thomas Davidson, um filósofo escocês, e reunia cientistas, escritores, políticos e intelectuais como George Bernard Shaw, Sidney Webb e Berthand Russell. Com efeito, tal como Fábio Máximo optava pela ausência de combate como estratégia, também esta sociedade tinha como fim estabelecer um Estado democrático baseado no socialismo, renunciando à necessidade de criar uma revolução para operar esta mudança social e política. Assim, esta filosofia é implantada na sociedade mediante uma educação decorrente de eventos públicos criados para este efeito, como palestras - cerca de 700 no ano de 1888 -, grupos de discussão, conferências e escolas de verão ${ }^{42}$. Em 1906, a Sociedade Fabiana conhecia já

${ }^{41}$ Eis a primeira resolução da Sociedade tomada na reunião intitulada "The Fellowship of a New Life", datada de 7 de Dezembro de 1884: "That the Society be called The Fabian Society (as Mr. Podmore explained in allusion to the victorious policy of Fabius Cunctator) was carried by 9 votes to 2.” in PeAse (2008: 21).

${ }^{42}$ Em 1889, G. Bernard Shaw publica aquele que é o seu tratado mais conhecido da Sociedade, Fabian Essays in Socialism, seguindo-se 
alguns frutos, sendo uma uma das responsáveis pela fundação do Partido Trabalhista britânico (1900). Além da Sociedade a nível nacional, outras emergiram em âmbito local - actualmente cerca de 63 -, tendo-se difundido na América e na Austrália já na década de cinquenta do século passado ${ }^{43}$.

Actualmente, esta Sociedade continua bastante activa: publica a revista Fabian Review, lança várias ediçóes de matéria política, organiza seminários, conferências e debates sobre temas cívicos. Além disso, ainda criou recentemente, em 2005, outra vertente, a Fabian Women's Network, que reúne cerca de 2000 mulheres.

Unus homo - um homem só visionário que empreendeu uma táctica militar tão criticada, mas que vigora, afinal, até aos nossos dias, como paradigma político e com repercussóes efectivas na sociedade, inspirando, desde o século XIX, geraçôes de políticos.

em 1952, New Fabian Essays, editado por Richard H. S. Crossman.

43 In "Fabian Society", The New Encyclopaedia Britannica, vol. 4 ( ${ }^{15} 1995$ : 647-8). A obra de Edward R. Pease, secretário da Sociedade durante vários anos, History of the Fabian Society: The Origins of English Socialism de 1916, conheceu duas reediçôes nos últimos dois anos. 


\section{TÁBUA CRONOLÓGICA}

\section{Roma/Vida de Fábio MáXimo}

\section{Século III A.C.}

ca. 283 Ano provável do nascimento de Fábio Máximo².

265 Eleito áugure, cargo que exerceu até à sua morte, durante 62 anos.

237-219 Os Barcas chegam à Hispânia e lá permaneceram durante 18 anos.

233 Cônsul pela primeira vez. Triunfo sob os Lígures $(2.1 ; 29(2))^{3}$.

230 Eleito censor.

228 Segundo consulado. Oposição à Lei Flamínia que propunha a distribuição do terreno, o ager Gallicus ${ }^{4}$, pelos colonos romanos mais necessitados.

221-19 Ditador pela primeira vez. Provavelmente em $221^{5}$.

218 Avanço de Aníbal. Vitória cartaginesa em Trébia (2. 2).

1 Para o estabelecimento desta cronologia, baseámo-nos sobretudo nas fixadas por R. Guerrini (1991: 285-286) e A. Pérez Jiménez (1996: 64-66)

${ }^{2}$ Vide nota 7 do capítulo "Introdução".

${ }^{3}$ Estas referências dizem respeito à Vida de Fábio Máximo.

${ }^{4}$ Terreno dos Sénones, situado entre Sena Gálica e Ravena, que fora conquistado pelos Romanos.

${ }^{5}$ Cf. Valério Máximo 1. 1. 5. 
217 Derrota do lago Trasimeno a 21 de Junho (3. 3). Fábio é nomeado ditador pelo povo (3.7).

Coloca em prática a estratégia contra Aníbal: adiar o ataque até que o inimigo desgaste a sua força com a falta de recursos (5. 1-2).

Fábio é enganado pela estratégia dos bois de cornos em chamas e soldados romanos são feitos prisioneiros (6.6-10).

O general vende a sua propriedade para poder pagar o resgate dos soldados (7.7).

Minúcio Rufo, o seu chefe de cavalaria, é eleito co-ditador, algo inédito (9.3-4).

Fábio salva Minúcio Rufo e suas legióes das tropas de Aníbal (12.4).

Termina o período de ditadura e são nomeados novos cônsules, G. Servílio Gémino e M. Atílio Régulo (14.1).

216 Derrota romana na Batalha de Canas (15-16).

Morte do cônsul Emílio Paulo (16.9) e fuga do colega Terêncio Varrão para a cidade de Venúsia.

Regressa, mais tarde, a Roma (18.4).

Fábio é eleito Pontífice Máximo.

215 Terceiro consulado na qualidade de consul suffectus $^{6}$, depois da morte do cônsul L. Postúmio Albino e da renúncia de M. Cláudio Marcelo, pois a sua eleição não foi validada pelos áugures (19.1).

214 Cônsul pela quarta vez juntamente com M. Cláudio

6 Substituto do cônsul que morre antes do termo da magistratura. 
Marcelo, a chamada dupla "O escudo e a espada de Roma” (19.4). Ambos defrontaram Aníbal (19. 5-6).

213 Q. Fábio Máximo, filho de Fábio, é eleito cônsul (24. 1-4).

211 Aníbal marcha sobre Roma (17.1). Cápua é reconquistada por Fúlvio e Ápio (29. (2)).

210 Cipião é nomeado procônsul na Hispânia (25.1).

209 Quinto consulado de Fábio juntamente com Q. Fúlvio Flaco. Reconquista de Tarento à traição (21-24).

205 Consulado de Cipião com Licínio Crasso (25.1). Morte do filho de Fábio. Encómio ao filho falecido $(1.9 ; 24.6)$.

Fábio tenta impedir a expediçẫo de Cipião ao norte de África (25. 2-26).

204 Cipião prossegue a campanha em África e conquista as primeiras vitórias (26.3).

203 Aníbal abandona Itália (26.4).

Morte de Fábio (27.2).

202 Cipião vence definitivamente Aníbal na batalha de Zama (27.1).

201 Tratado de paz entre Roma e Cartago. 


\section{VIDA DE FÁBIO MÁXIMO}


(Página deixada propositadamente em branco) 
1. Depois de expor o que foi Péricles nas acçóes dignas de memória, tal como as recebemos, passamos agora à história de Fábio.

2. Dizem que de uma ninfa ou, segundo outros, de uma mulher daquele sítio, que se uniu a Herácles na margem do rio Tibre, nasceu Fábio, o fundador da família dos Fábios, numerosa e notável em Roma1. Contudo, alguns autores estabeleceram que os primeiros membros desta família se chamavam, antigamente, Fódios pelo facto de caçarem com buracos, pelo que ainda hoje se dá o nome de fossae aos buracos e fodere à acção de cavar; mas, com o tempo, alteraram-se as duas letras e foram apelidados de Fábios.

3. Muitos e grandes homens produziu aquela casa, nomeadamente Ruliano ${ }^{2}$, o mais importante, que por isso era chamado Máximo entre os Romanos, sendo dele que descende, em quarta geração ${ }^{3}$, o Fábio Máximo

${ }^{1}$ Este dado é também testemunhado por Juvenal, Sátiras 8. 14.

${ }^{2}$ Q. Fábio Máximo Ruliano foi cinco vezes cônsul em 322, 310 , 308, 297, 295 a.C., pelo que foi o elemento mais influente desta família no século IV a. C. Durante os seus consulados, obteve a vitória sobre os Samnitas, Apúlios, Etruscos, bem como na batalha de Sentino, em 295 a.C.

${ }^{3}$ Reconhecida também por Plínio, História Natural 7.133, a genealogia em que Plutarco se baseia é a seguinte: Q. F. Máximo Ruliano foi pai de Q. F. Máximo Gurges, de quem procede Q. F. Máximo Gurges, que tem como descendente o Fábio Máximo biografado. O avô de Fábio Máximo - segundo a genealogia seguida por Plutarco - teve dois consulados em 292 e 276 a.C.; o pai de 
sobre quem escrevemos a biografia. 4. Um pormenor físico valeu-lhe o apelido de Verrugoso ${ }^{4}$, pois tinha uma pequena verruga a crescer acima do lábio; o de Ovícula, que significa "cordeirinho", foi-lhe atribuído graças à doçura e tranquilidade do seu carácter, quando era ainda uma criança. 5. A sua calma e silêncio, e a muita prudência com que se entregava aos prazeres infantis, a lentidão e a dificuldade com que aprendia as matérias, a complacência e a submissão para com os seus amigos, fez com que aqueles que o conheciam mal suspeitassem de alguma estupidez e preguiça. Apenas alguns distinguiam, no fundo, a firmeza, a generosidade e a coragem leonina na sua natureza. 6. Contudo, o tempo rapidamente passou e sendo despertado pela actividade política, a todos provou que a sua aparente apatia era, na verdade, impassibilidade, a precaução, prudência, e a falta de reacção e agilidade perante qualquer circunstância antes eram constância e a firmeza. 7. Observando a grandeza do Estado e as numerosas guerras, treinou o seu corpo para o combate, como uma arma natural, e o discurso como instrumento de persuasão dirigido ao povo, adequandose perfeitamente ao seu modo de vida. 8. Não havia, no seu discurso, nem o ornamento nem a vã eloquência forense, mas a razão tomava nas suas palavras um estilo particular e uma profundidade invulgar nas sentenças,

Fábio, homónino deste último, teria sido também cônsul em 265 a.C. Os testemunhos dividem-se quanto à paternidade de Fábio, pois enquanto uns consideram que F. Máximo Ruliano é avô (Tito Lívio 30. 26. 8), outros defendem, como Plutarco e Plínio, que é seu bisavô.

${ }^{4}$ Cf. Sobre os varōes ilustres 43. 1 e Cícero, Bruto 57.5. 
muito semelhantes, dizem, àquelas de Tucídides. 9. Conservamos ainda, com efeito, um discurso dele proferido diante do povo: um encómio ao filho ${ }^{5}$ que morreu depois de ter sido cônsul.

2. Dos cinco consulados que exerceu, no primeiro conquistou o triunfo sobre os Lígures ${ }^{6}$. Vencidos por ele na batalha, quando muitos tinham já perdido contra eles, foram repelidos até aos Alpes, deixando de pilhar e fazer estragos na regiáo fronteiriça à Itália. 2. Aníbal, depois de invadir a Itália e vencer a primeira batalha nas margens do rio Trébia ${ }^{7}$, penetrou através da Etrúria e arrasou o país, provocando em Roma consternação e um medo terrível. Sinais surgiram, alguns familiares aos Romanos como os raios, outros completamente inéditos e muito estranhos ${ }^{8}$. Diz-se, por exemplo, que certos escudos transpiraram, eles mesmos, sangue, que perto de Âncio se cortaram espigas de trigo ensanguentadas, que do ar caíram pedras de fogo ardentes, que sobre os Falérios ${ }^{9}$ se via o céu abrir-se e, nisto, caíam numerosas tabuinhas, que se espalhavam aqui e ali, numa das quais, estava

${ }^{5}$ Cf. Cícero, Da Velhice 12-13, Tusculanas 3, 70, Cartas aos Amigos 4. 6.1.

${ }^{6}$ A vitória teve lugar no ano de 233 a.C.

${ }^{7}$ Em Dezembro de 218 a.C., Aníbal venceu P. Cornélio Cipiáo e T. Semprónio.

${ }^{8}$ Estes prodígios e outros mais sáo mencionados por Tito Lívio 22.1, 8-12, ao contrário de Políbio, historiador racionalista, que não faz referência a estes acontecimentos. Vide o tratado de Plutarco, Da Superstição (164e-171f).

${ }^{9}$ Cidade capital dos Faliscos, situada na zona meridional da Etrúria, actualmente designada por Cività Castellana. 
escrito com todas as letras: "Marte agita as suas armas." 10

3. Nenhum destes prodígios impressionou Gaio Flamínio $^{11}$. Homem de natureza ardente e ambiciosa, exaltado pelos grandes sucessos que antes conseguira de forma imprevista, quando, apesar da ordem do Senado e da veemente oposição do seu colega de consulado, empreendeu uma guerra contra os Galos e os derrotou ${ }^{12}$. Fábio, por sua vez, apesar de muitos terem ficado impressionados, não se deixou perturbar por aqueles sinais, dada a sua irracionalidade. 4. Informado, porém, do número reduzido de inimigos e da sua escassez de recursos, aconselhou os Romanos a ter paciência e a não fazer guerra contra um homem que comandava um exército treinado em muitos combates para aquele em concreto, e, em vez disso, a enviar ajuda aos aliados de forma a manter o controlo sobre estas cidades, deixando que a força de Aníbal se extinguisse por si mesma, como uma chama que brilha com todo o vigor até ficar pequena e fraca ${ }^{13}$.

${ }^{10}$ Vide Tito Lívio 21. 11.

${ }^{11}$ Gaio Flamínio foi nomeado tribuno da plebe em 232 a.C. e era um novus homo, ou seja, o primeiro elemento da sua família a alcançar um lugar no Senado, tendo levado a cabo uma política agrária contrária à classe senatorial. Eleito pretor em 227 a.C., Flamínio foi o primeiro governador anual da Sicília, mas foi no seu consulado (223 a.C.) que alcançou maior notoriedade, pela sua vitória contra os Ínsubres. Nomeado depois censor em 220 a.C., foi o único defensor de Q. Cláudio em 218 a.C. na lex Claudia. Este acto público e a sua origem conquistaram a confiança do povo, que o elevou ao consulado em 217 a.C.

12 A vitória teve lugar em 223 a.C., durante o seu primeiro consulado sobre os Galos. Cf. Políbio 2. 32-33; Plutarco, Marcelo 4. 2-6.

${ }^{13}$ Imagem homérica; Ilíada 9. 212. 
3. Não convenceu, contudo, Flamínio. Este declarou que não consentiria que a guerra se aproximasse de Roma e que não faria como o antigo Camilo ${ }^{14}$, que travou um combate pela cidade dentro da mesma ${ }^{15}$, pelo que ordenou aos tribunos que mandassem sair o exército e ele mesmo saltou para o cavalo. $\mathrm{O}$ animal, sem causa aparente, começou a tremer de forma inesperada, assustou-se e Flamínio foi derrubado e caiu de cabeça ${ }^{16}$. Este incidente, contudo, não alterou a sua resolução e seguiu o seu primeiro impulso: ir ao encontro de Aníbal e colocar as suas tropas em linha de batalha perto do chamado lago de Trasimeno, na Etrúria ${ }^{17}$. 2. Quando os exércitos se preparavam para o combate, precisamente no momento crucial da batalha, ocorre um terramoto que arrasou cidades, desviou os rios dos seus leitos e abriu fendas nas montanhas até à base. Contudo, apesar

${ }_{14}$ Trata-se de Fúrio Camilo, tribuno consular em 401, 398, 394, 386, 384, 381 a.C., supostamente censor em 403 e dictator em 396, 390, 389, 368, 367 a. C. e que conduziu uma investida contra os Gauleses em 390 a.C.

${ }^{15}$ Cf. Tito Lívio 22. 3. 10.

${ }^{16}$ Tito Lívio (22. 3. 11) quando menciona este episódio, refere que "o cavalo se abateu subitamente e fez cair o cônsul por cima da sua cabeça” [equus repente corruit consulemque lapsum super caput effudit]. É, por isso, provável que Plutarco não tenha compreendido o texto latino. O biógrafo reconheceu, com efeito, estas limitaçóes em Demóstenes 2. 2-3, recordando que quando se encontrava em Roma não tinha tempo para se dedicar ao estudo da língua latina pois tanto os afazeres públicos como os que buscavam os seus conhecimentos de filosofia absorviam todo o tempo. Só mais tarde, pôde começar a estudar a literatura romana.

${ }^{17} \mathrm{O}$ combate teve lugar na Primavera de 217 a.C., no dia 21 de Junho, segundo Ovídio, Fastos 6. 765-768. 
da violência do fenómeno, nenhum dos combatentes se apercebeu $^{18}$. 3. Flamínio, depois de ter dado provas de muitos actos de audácia e coragem, morreu e, com ele, os melhores homens. Os restantes entregaram-se à fuga e houve grande mortandade: quinze mil foram talhados em pedaços e outros tantos foram feitos prisioneiros ${ }^{19}$. Aníbal, querendo dignificar o corpo de Flamínio com ritos fúnebres e prestar-lhe honra pelo seu valor, não o encontrou, entre os cadáveres, e jamais souberam como desapareceu ${ }^{20}$.

4. A derrota ocorrida junto ao rio Trébia, nem o general que escreveu a notícia, nem o mensageiro enviado, a anunciaram claramente, tendo mentido, dizendo que a vitória tinha sido controversa e duvidosa ${ }^{21}$. Contudo, assim que o pretor Pompónio teve conhecimento desta notícia, reunindo o povo em assembleia geral e sem perífrases ou mais rodeios, avançou e disse abertamente: 5. "Romanos, fomos vencidos numa grande batalha ${ }^{22}$; o exército foi destruído e o cônsul Flamínio morreu. Deliberai agora sobre a vossa salvaçáo e segurança." 6. Esta declaração lançada sob uma multidão tão ingente, como um furacão no mar, espalhou a desordem na cidade, e diante de tamanho terror, as faculdades racionais não se puderam conservar ou manter firmes. 7 . Nisto, todos

${ }^{18}$ Cf. Tito Lívio 22.5.8.

${ }^{19}$ Estes números coincidem com os de Políbio 3.84-85 e Tito Lívio 22.7, 2-5, menciona o número de mortos, mas não refere prisioneiros.

${ }^{20}$ Cf. Tito Lívio 22.7.5 e Valério Máximo 1.6.6, que fazem também referência ao desaparecimento do corpo.

${ }^{21}$ Cf. Políbio 3.75.

${ }^{22}$ Cf. Tito Lívio 22.7.8 e Políbio 3.85.7. 
chegaram a um acordo: a situação exigia uma autoridade e o poder de um só, o que chamam de ditadura ${ }^{23}$, e um homem que o exercesse sem hesitação e com segurança; e este homem só podia ser Fábio Máximo, que possuía a sabedoria, e a nobreza de carácter à altura daquele cargo, além de que estava na idade em que o vigor do corpo suporta as resoluçóes do espírito e em que a audácia se alia à prudência.

4. Tomada esta decisão, Fábio, nomeado ditador ${ }^{24}$, designou ele próprio Marco Minúcio ${ }^{25}$ para a função de comandante da cavalaria ${ }^{26}$. O primeiro pedido que fez

${ }^{23}$ Vide "Introdução Geral", n. 5.

${ }^{24}$ Neste caso, o título seria, em rigor, prodictator, pois a nomeação foi feita pelo voto popular nos comitia centuriata. Outros testemunhos como Tito Lívio 22.8 e Políbio 3. 87. 6-9 não atribuem a eleição do ditador ao povo. Com efeito, só um magistrado com imperium (cônsul, pretor ou interrex) tinha o poder de nomear, em público (dictatorem dicere) e com autorização prévia do Senado, o ditador ou magister populi. Contudo, não era possível fazer as eleiçóes por esta via, pois um cônsul, Gaio Flamínio, tinha morrido em combate enquanto o seu colega, o cônsul Servílio, estava ausente de Roma. Semelhante à monarquia (Cícero, República 2. 59), raramente se recorria a esta forma de governo, sendo usada apenas em situaçóes de crise militar, pois o eleito detinha poder absoluto sobre as instituiçóes políticas, ainda que fosse apenas por seis meses.

${ }^{25}$ M. Minúcio Rufo tinha sido nomeado cônsul em 221 a.C. em conjunto com P. Cipião Ásina. Morrerá, no ano seguinte na batalha de Canas (216 a.C.).

${ }^{26} \mathrm{O}$ relato de Plutarco diverge daquele de Tito Lívio (22.8.7) e de Políbio (3.87.9). Com efeito, ambos os historiadores dizem que foi o povo quem elegeu o magister equitum juntamente com o ditador. Como refere, a propósito desta eleição, o historiador Goldsworthy (22007: 44): "Normalmente, o ditador escolhia o seu chefe da Cavalaria, mas, nas excepcionais circunstâncias em 
ao Senado foi o poder ir a cavalo durante as expediçôes militares. 2. Ele não tinha, com efeito, este direito: uma antiga lei o proibia, seja porque consideravam a infantaria a força principal do seu exército e julgavam que o general devia permanecer junto da falange, náo a podendo abandonar, seja porque o poder que o cargo, lhe concede é enorme e tem todas as características da tirania, e é suposto que ao menos nisto pareça que o ditador está subordinado ao povo.

3. Com efeito, o próprio Fábio, querendo logo mostrar a grandeza e a majestade do cargo, de forma a tornar mais dóceis e obedientes os cidadáos, saiu a público com vinte e quatro lictores reunidos à sua volta $^{27}$. Assim, quando o outro cônsul ia ao seu encontro, enviou o seu ajudante e ordenou-lhe que mandasse embora os lictores, deixasse as insígnias daquele cargo e se apresentasse como um cidadáo comum.

4. Depois disto, inaugurou o cargo com o mais belo princípio, começando pelos deuses, dando a entender ao povo que a derrota tinha ficado a dever-se

que Fábio foi eleito, foi decidido conceder também aos eleitores o direito de escolher o seu subordinado." Este título pode ser um vestígio dos tempos arcaicos da história de Roma, quando a maioria do exército correspondia à falange hoplita, e, enquanto o ditador comandava a infantaria pesada, o subordinado, magister equitum, dirigia a cavalaria. Tal como o do dictator, este cargo tinha também um carácter temporário, terminando com o fim da ditadura. Sobre os problemas associados às eleiçóes de 217 a.C., vide Sumner (1975).

${ }^{27}$ A cada cônsul era permitido ter doze lictores, mas o ditador, como concentrava em si todo o imperium, teria direito a vinte e quatro, símbolo de um poder pleno equivalente a dois cônsules. Sobre este episódio, cf. Tito Lívio 22.11.5-6. 
à negligência e ao desprezo do general pelos deuses, e náo à incapacidade dos combatentes; exortou-o a não temer os inimigos, encorajando-o antes a apaziguar e honrar os deuses ${ }^{28}$. Não para alimentar a superstição, mas para fortalecer com a piedade e a coragem, e, com as esperanças postas nos deuses, apagar o medo dos inimigos, reconfortando-os. 5. Recorreu-se, então, a muitos livros secretos utilizados pelos Romanos, que se chamavam sibilinos ${ }^{29}$ e diz-se que algumas das profecias que aí constavam se reportavam a situaçóes e a acontecimentos de entáo. 6. A nenhuma outra pessoa era permitido saber o que lá se lia, à excepção do ditador. Este, apresentando-se diante da multidão, fez o voto de oferecer aos deuses tudo quanto se produzisse na Itália inteira, entre cabras, porcos, reses e bois, tanto nas montanhas como nas planícies, nos rios e pradarias, na Primavera seguinte ${ }^{30}$; de celebrar espectáculos musicais e cénicos ${ }^{31}$ no valor de trezentos e trinta e três sestércios e trezentos e trinta e três denários

${ }^{28}$ Cf. Tito Lívio 22. 9. 7 e Políbio 3.88.7.

${ }^{29}$ Designados também de Livros do Destino (libri fatales), os Livros Sibilinos eram uma colectânea muito antiga de oráculos gregos provenientes, segundo a lenda, da Etrúria e de Cumas, na Campânia, sendo na realidade uma herança etrusca. A leitura destes livros permitia conhecer a vontade divina e era solicitada em alturas de grande infortúnio, tendo tal acontecido pela primeira vez em 436 a.C. No tempo de Fábio Máximo, a consulta destes livros era exclusiva de um colégio, o grupo dos Decemviri sacris faciundis.

${ }^{30}$ Trata-se do Ver sacrum ("Primavera sagrada"), prática religiosa itálica que consistia na consagração aos deuses, em momentos de crise, de tudo o que nascesse na Primavera seguinte.

${ }^{31}$ Segundo Tito Lívio (22.10.7), tratavam-se dos Ludi Magni, oferecidos em honra de Jupiter Optimus Maximus. 
e ainda um tritartemórion ${ }^{32}$, soma que hoje equivale a oitenta e três mil, quinhentas e oitenta e três dracmas e dois óbolos. 7. É, com efeito, difícil dizer qual a razão da exactidáo e da minúcia deste montante, a não ser que, porventura, quisesse enaltecer o valor do número três, já que é ele, por natureza, o número perfeito: o primeiro dos números ímpares, o princípio causal da pluralidade, reúne em si mesmo as primeiras diferenças e os elementos de todos os números, combinando-os, e harmonizando-os numa união conjunta ${ }^{33}$.

5. Ao levantar o ânimo da multidão por meio da religião, Fábio inspirou mais confiança no futuro. Com efeito, colocando em si mesmo todas as esperanças na vitória, convencido de que os deuses concedem os sucessos mediante o valor e a sabedoria, irá ao encontro de Aníbal, não com a intenção de combater, mas decidido a desgastar e consumir a sua força com o tempo, a falta de recursos dele com o seu dinheiro, e a falta de homens daquele com a abundância deles da sua parte $^{34}$. 2. Por esta razáo, ficava sempre nas alturas, acampando em zonas montanhosas, longe do alcance da cavalaria inimiga, tranquilo quando o inimigo estava calmo, e, quando este se movia, andava às voltas sem deixar os pontos altos, mostrando-se à distância e de

${ }^{32}$ Moeda de prata que equivale a três quatros de um óbolo e a um oitavo de um dracma. Cf. Pólux 9.65.

33 Sobre o interesse de Plutarco pelo número três, vide Obras Morais 288 D, 374 A, 738 F, 744 F, 1020 D.

${ }^{34}$ É esta a estratégia que celebrizou Fábio como Cunctator, o contemporizador. Cf. Políbio 3, 82, 4 e Tito Lívio 22.3, 8-9. 
forma a não apresentar combate sem querer e, com a espera, fomentar o medo nos inimigos como se fosse apresentar combate a qualquer momento.

3. Contudo, por deixar o tempo passar, era criticado por todos. Falava-se mal dele no acampamento e, entre os inimigos, era visto como cobarde e inútil; à excepção de Aníbal. 4. Era este o único que reconhecia a habilidade e a forma como ele conduzia a guerra, convencido de que ou o obrigava a combater por meio de qualquer estratégia ou pela força ou, caso contrário, estaria perdida a causa dos Cartagineses. Como náo podiam servir-se de armas que os tornariam mais fortes $\mathrm{e}$, sendo inferiores em homens e dinheiro, via os seus recursos diminuírem e esgotarem-se em vão. Aníbal recorreu a todo o tipo de estratégias e manobras, fazendo constantes intentos, como um hábil atleta que procura a ocasião para atacar: aproximava-se, criava confusão e procurava atrair Fábio para diversos lugares, querendo que ele desistisse da táctica que garantia a sua segurança. 5. Contudo, como este estava convencido da sua utilidade, a sua resolução permanecia fiel e inalterável. Importunava, porém, Minúcio, o comandante da cavalaria, que, sedento de combate, com impertinência procurava seduzir os soldados, encorajando-os para um acto tresloucado, enchendo-os de vãs esperanças. Assim, estes faziam pouco e desprezavam Fábio, chamando-o de pedagogo ${ }^{35}$ de Aníbal, e a Minúcio, por sua vez,

35 Esta acusação era especialmente ofensiva, pois indicava uma relação de subordinação e inferioridade. $\mathrm{O}$ pedagogo era o escravo que tinha a missão de acompanhar a criança à escola e vigiá-la onde quer que ela estivesse. Cf. Tito Lívio 22.12.11-12. 
viam-no como um grande homem e um general digno de Roma. 6. Este, deixando-se levar pelo orgulho e pela insolência, ridicularizava o facto de ter acampado nas alturas, dizendo que deste modo o ditador oferecia bons lugares para assistir ao belo espectáculo de uma Itália devastada e queimada; e perguntava aos amigos de Fábio se, com tanto subir, pretendia levar o exército para o céu, como se tivesse já desistido da terra, ou se, para escapar aos inimigos, lhes atiraria nuvens e neblinas. 7. Quando os amigos contaram a Fábio estas notícias e o aconselharam a libertar-se destas afrontas com uma empresa arriscada, ele respondeu: "Assim, certamente", disse, "parece-me que seria mais cobarde do que agora pareço se, por temer sarcasmos e injúrias, deixasse cair a minha estratégia. 8. Além disso, não é vergonhoso temer pela pátria e náo me parece digno de um homem de tamanho cargo deixar-se influenciar pelas calúnias e censuras dos homens, mas antes próprio do escravo que se submete aos insensatos, sobre os quais ele deve ser chefe e mestre" ${ }^{36}$.

6. Algum tempo depois, Aníbal cometeu um erro ${ }^{37}$. Querendo levar o seu exército para bem longe de Fábio e ocupar as planícies que tivessem pasto, ordenou aos guias que, depois do jantar, o conduzissem atéà região de Casino. 2. Estes, porém, não entenderam bem a ordem por causa da sua pronúncia bárbara e levaram-no até aos limites

${ }^{36}$ Cf. Plutarco, Obras Morais 195 C e Marcelo 9.7; Diodoro 26.3.

${ }^{37}$ Para os assuntos narrados neste capítulo 6, cf. Tito Lívio 22. 13-17 e Políbio 2.92-94. 
da Campânia e fizeram o exército entrar nas imediaçôes de Casilino, regiáo que dividia em duas metades o rio Lótrono, que os Romanos chamavam de Volturno ${ }^{38}$. 3. A região está coroada de montanhas por todos os lados, menos por um, abrindo-se um canal para o mar, onde se revela um rio que forma pauis e tem profundos bancos de areia que culminam numa praia com forte ondulação e de difícil acesso. 4. Quando Aníbal descia por ali, Fábio deu uma volta, e aproveitando o facto de conhecer bem os caminhos, bloqueou a saída dispondo lá quatro mil homens da infantaria; depois, tendo colocado o resto do seu exército num lugar estratégico nos pontos mais altos, ataca, com as tropas mais ligeiras e melhor organizadas, a retaguarda do inimigo, gerando confusão em todo o exército e matando cerca de oitocentos combatentes. 5 . Aníbal, querendo bater em retirada com o exército dali para fora, reconheceu o erro e o perigo daquele lugar, crucificou os guias, mas renunciou empreender uma luta contra os inimigos, pois eram superiores nas zonas altas. 6. Vendo os soldados desanimados e temerosos por pensarem que estavam cercados por todos os lados e sem escapatória, Aníbal arquitectou um ardil para enganar os inimigos ${ }^{39}$. O estratagema era o seguinte: mandou recolher cerca de dois mil bois entre os despojos, atando a cada corno uma tocha, um feixe de vime de sarça ou de mato seco. Mais tarde, quando a noite sobreveio, acenderam as tochas e conduziram os bois

${ }^{38}$ Cf. Tito Lívio 22.13.5-6.

${ }^{39}$ Cf. Tito Lívio 22.16.17 e Políbio 3.93-94. 
até às alturas, em direcção aos desfiladeiros e aos vigias dos inimigos. 7. Enquanto uns recebiam ordens para fazer os preparativos necessários, ele mesmo colocou em marcha o resto do exército, já na escuridão, fazendo-os avançar lentamente.

Os bois, enquanto o fogo era fraco e ardiam apenas as ramas, avançavam lentamente, sendo conduzidos até ao cume das montanhas: os fogos que brilhavam no alto dos cornos constituíam um espectáculo para pastores e boieiros que observavam do alto, pensando que era um exército que marchava ordenado à luz de muitas tochas. 8. Mas quando o fogo queimou as hastes e atingiu a raiz dos cornos, então sentiu-se o odor a carne, as reses dispersaram-se, sacudindo as cabeças, pegaram fogo umas às outras e já não se mantiveram na ordem em que caminhavam. Aterrorizadas e flageladas pela dor, lançaram-se em corrida pelos montes abaixo, com os rabos e a testa em chamas, e no mato, por onde fugiam, espalhavam o fogo. 9. Horrível era a visão para os Romanos que vigiavam as zonas mais altas. De facto, as chamas pareciam tochas carregadas por homens correndo, e com isto instala-se entre eles muita confusão e pânico, pois acreditavam que os inimigos viriam de todos os lados e que estavam cercados por toda a parte; por isso, não ousaram permanecer nos seus postos, e retirou-se a maior parte do exército, abandonando os desfiladeiros.

10. Neste momento, as tropas ligeiras de Aníbal alcançam e ocupam as alturas, enquanto o resto do exército avança sem temor, arrastando consigo um volumoso e pesado despojo. 
7. Ainda durante a noite, Fábio apercebeu-se do ardil, pois alguns bois, que se dispersaram durante a fuga, foram cair nas suas mãos; mas porque temia alguma emboscada, não avançou e manteve o seu exército em alerta. 2. Quando nasceu o dia, começou a perseguição e atacou a retaguarda do inimigo. Ocorreram confrontos em terrenos acidentados e o tumulto foi grande, até que da parte de Aníbal foram enviados os ágeis e rápidos Iberos $^{40}$, treinados para subir montanhas, que atacaram a pesada infantaria dos Romanos, e, depois de matarem alguns homens, obrigaram Fábio a recuar ${ }^{41}$.

3. Este recebe, então, as piores imprecações e desprezo $^{42}$. Ao renunciar à audácia das armas, de forma a fazer guerra à força de prudência e previsão, foi ele quem, afinal, saiu derrotado por estas e vítima da sua própria estratégia ${ }^{43}$.

4. Aníbal, querendo incendiar ainda mais a ira dos Romanos contra ele, quando se aproximou das suas terras, ordenou que destruíssem e queimassem todas as outras, mas proibiu que tocassem nos campos de Fábio - e apenas nestes ${ }^{44}$ - e colocou mesmo aí um vigia que não permitisse qualquer dano ou ataque.

40 Designação étnica de um dos primitivos povos da Hispânia. No final do século V a.C., os Iberos eram conhecidos como mercenários: habituados às adversidades das montanhas, caracterizavam-se pela sua agilidade e rapidez e correspondiam à maior parte do exército de Aníbal.

${ }^{41}$ Cf. Políbio 3.94. 6.

${ }^{42}$ Cf. Políbio 3.94. 8.

${ }^{43}$ Cf. Tito Lívio 22.23.4.

${ }^{44} \mathrm{O}$ mesmo sucedeu ao primeiro elemento deste par de Vidas, Péricles (33.2). 
5. Quando estas notícias chegaram a Roma, aumentaram as calúnias contra Fábio. Os tribunos da plebe náo paravam de gritar contra ele diante da multidão. Quem os incitava e provocava ainda mais era Metílio, não por ódio pessoal contra Fábio, mas por ser parente de Minúcio, o comandante da cavalaria, e por pensar que aquelas maledicências traziam a este último honra e glória. Acontece que também o Senado estava irado contra ele e o censurava sobretudo por causa do acordo que tinha firmado com Aníbal em relação aos cativos de guerra: tinham acordado entre si trocar homem por homem dos prisioneiros, e a dar-se o caso de um ter mais do que o outro, pagar por cada um dos capturados duzentas e cinquenta dracmas. 6. Com efeito, realizadas as permutas de homens, descobriu-se que duzentos e quarenta romanos ${ }^{45}$ estavam em poder de Aníbal, pelo que o Senado decidiu não enviar o montante e culpou Fábio pelo facto de, sem olhar à honra nem ao interesse, querer resgatar soldados tấo cobardes que se deixaram capturar pelo inimigo. 7. Fábio, tendo conhecimento da recusa, suportou, pacientemente, a ira dos cidadáos. Assim, como não tinha riquezas, mas tampouco queria faltar à palavra a Aníbal ou abandonar os seus concidadáos, enviou o seu filho a Roma, ordenou-lhe que vendesse as terras ${ }^{46}$ e que lhe remetesse o dinheiro o mais rápido possível para o acampamento.

8. Quando o jovem vendeu as terras e regressou, Fábio enviou a importância a Aníbal e recuperou os

\footnotetext{
${ }^{45}$ Cf. Tito Lívio 22.23.7.

${ }^{46}$ Cf. supra 7.2.
} 
cativos. Mais tarde, muitos quiseram devolver-lhe a quantia, mas não aceitou da parte de ninguém e perdoou a todos.

8. Pouco tempo depois, os sacerdotes chamaramno a Roma para alguns sacrifícios; entregou as forças a Minúcio, proibindo-o expressamente de oferecer guerra ou confrontar-se com o inimigo, não só na qualidade de ditador, mas fazendo também muitas exortaçóes e $\operatorname{pedidos}^{47} .2$. Ele, porém, não os levou em conta e atacou logo o inimigo. Certo dia, tendo reparado que Aníbal tinha enviado a maior parte do exército para recolher provisóes, atacou aqueles que tinham permanecido no acampamento, empurrou-os para dentro da paliçada, matou um número não pequeno, e aterrorizou todos aqueles que estavam cercados por ele. 3. Nisto, enquanto Aníbal reunia de novo as suas forças para o acampamento, retirou-se de forma segura. Tal sucesso encheu-o a ele e aos soldados, de uma soberba desmedida e de insolência.

4. Rapidamente se espalhou em Roma uma fama maior do que a própria acção. Fábio, tomando conhecimento do sucedido, disse que temia mais o sucesso de Minúcio do que o insucesso. $O$ povo, porém, exaltou-se e, alvoraçado, reuniu-se no fórum. Metílio, tribuno da plebe, quando subiu à tribuna, discursou enaltecendo Minúcio e acusando Fábio, não de brandura ou cobardia, mas já de traição. Culpava, ao mesmo tempo, os mais poderosos e importantes

${ }^{47}$ Cf. Tito Lívio 22.18. 8-10; Políbio 3.94.9. 
entre os Romanos pela forma como a guerra tinha sido conduzida, determinando a ruína do povo desde o início, lançando directamente a cidade para um poder único sem controlo; e Fábio, por sua vez, perdendo tempo na sua estratégia, oferecera a Aníbal comodidade e tempo para trazer novas forças da Líbia, como se fosse dono de Itália ${ }^{48}$.

9. Fábio apareceu diante de todos e não procurou defender-se do tribuno e disse apenas que era necessário celebrar o quanto antes os sacrifícios ${ }^{49}$ e as cerimónias religiosas, de forma a regressar ao acampamento e impor a Minúcio o castigo por ter apresentado batalha aos inimigos, contra a sua proibição. Espalhou-se então pelo povo um grande tumulto, por causa do risco que ameaçava Minúcio. Com efeito, como o ditador tinha o direito de prender e condenar à morte sem julgamento prévio, pensavam que o espírito de Fábio, agora sem a sua mansidão, se tornaria inflexível e implacável ${ }^{50}$. 2 . Assim, todos os outros, assustados, fizeram silêncio, mas Metílio, graças à imunidade que detinha enquanto tribuno - é a única magistratura que não perde o poder quando é eleito o ditador, conservando-o enquanto que os outros são dissolvidos - perseguia insistentemente o povo e pedia-lhe que não abandonasse Minúcio nem o deixasse sofrer o que Mânlio Torquato $^{51} \mathrm{fez}$

${ }^{48}$ Cf. Tito Lívio 22.25.3-11.

${ }^{49}$ Cf. Tito Lívio 22.18.8 e Políbio 3.94.9.

${ }^{50}$ Cf. Tito Lívio 22.25.2 e Plutarco, Obras Morais 195 C.

51 T. M. Imperioso Torquato teve uma carreira política fulgurante, tendo sido o membro mais influente da sua família no 
a seu filho, que, apesar de estar triunfante e coroado de louros, cortou-lhe o pescoço com um machado; que retirasse a tirania a Fábio e transferisse os assuntos públicos para quem podia e queria salvá-los. 3. Exaltada com estes discursos, a multidão não se atreveu a pedir a Fábio que depusesse o poder absoluto, apesar da sua impopularidade. Ao invés, no que a Minúcio diz respeito, decretou, por votação, que o cargo de general se equiparava ao de chefe e actuava na guerra com a mesma autoridade que o ditador. 4. Com efeito, esta situação nunca se tinha dado antes em Roma, e repetiuse mais tarde aquando do desastre de Canas.

Então, quando Marco Júnio, o ditador, estava à frente do exército, na cidade, nomearam como segundo ditador Fábio Butéon ${ }^{52}$, de forma a completar o Senado, já que muitos senadores tinham morrido na batalha. 5. A única diferença foi que este, depois de eleito, tão depressa quanto nomeou membros e completou o Senado, no mesmo dia, despediu os lictores, livrou-se da sua escolta e, misturando-se no meio da multidão, com ela se confundiu, e, como um particular, regressou

século IV: tribuno militar em 361 a.C., três vezes ditador (353, 349, 320 a.C.), foi também cônsul por três vezes em 347, 344, 340 a.C. Um dos episódios mais conhecidos com ele relacionado diz respeito à condenação do seu filho Tito Mânlio à morte por ter avançado contra o inimigo, contra as suas ordens. Apesar de o filho ter derrotado o inimigo em 340 a.C., não deixou de lhe aplicar a pena de morte. Cf. Tito Lívio 8.7.

2 Cf. Tito Lívio 23, 22, 10. M. Fábio Butéon foi eleito cônsul em 245 a.C. e censor em 241 a.C. Após o desastre da batalha de Canas, como era o censor mais antigo, foi eleito ditador no final desse ano (216 a.C.) de forma a reunir poderes para completar o Senado. 
ao fórum para controlar e tratar dos seus próprios negócios ${ }^{53}$.

10. Depois de terem atribuído a Minúcio as mesmas funçôes do ditador, julgavam ver Fábio diminuído e humilhado, mas não conheciam bem este homem. 2. Com efeito, não considerava desgraça sua a ignorância dos outros, mas antes agia como o sábio Diógenes ${ }^{54}$ quando alguém lhe disse "Este riem-se de ti", e ele respondeu "mas eu, não me rio", pois entendia que os únicos que eram alvo de riso eram aqueles que fraquejavam e se deixavam perturbar perante tais situaçóes. Do mesmo modo, Fábio suportou os seus ultrajes, impassivelmente e com serenidade, de forma a servir de exemplo aos filósofos que sustentam que não é possível insultar ou desonrar o homem bom e virtuoso. 3 . Lamentava, contudo, a irreflexão das massas em relação ao interesse público, já que tinham proporcionado oportunidades de guerra à insana ambição daquele homem. 4. E, temendo que Minúcio, completamente desequilibrado pela sua vanglória e orgulho, se apressasse a fazer algum disparate, saiu escondido de todos. 5. Com efeito, ao chegar ao acampamento, constatou que Minúcio já não era controlável, pois, insolente e arrogante, exigia o comando alternado do exército ${ }^{55}$.

${ }^{53}$ Cf. Tito Lívio 23.22.10 e 23.

${ }^{54}$ Trata-se de Diógenes de Sinope (ca. 412/403- ca. 324/321 a.C.), famoso Cínico. Vide Halliwell (2008: 375-81).

${ }^{55}$ Esta resolução confere a Minúcio Rufo o título de co-ditador, colocando Fábio Máximo numa situaçáo ambígua. O mesmo se repete com Fábio Butéon, depois da batalha de Canas, facto referido mais adiante (9. 4-5). 
Este, porém, não aceitou, tendo dividido com ele as forças, de forma a controlar uma das partes, que era melhor do que comandar todo o exército de forma alternada. 6. Tomou para si a primeira e quarta legióes e entregou àquele a segunda e a terceira, repartindo por igual as tropas aliadas ${ }^{56} .7$. Minúcio estava muito jactante e contente porque o fausto do cargo mais elevado foi rebaixado e ultrajado por sua causa. Nisto, Fábio recorda-o de que o seu combate não era contra Fábio, mas sim contra Aníbal, se era sensato, e que, se queria competir com o seu colega, se preocupasse então em evitar que aquele que tinha sido honrado e saído vitorioso diante dos cidadáos parecesse cuidar menos da segurança e estabilidade deles do que aquele que tinha sido vencido e ultrajado.

11. Pretensóes senis, lhe pareciam estas advertências. Tomou a parte do exército que lhe coube em sorte e acampou à parte e noutro lugar ${ }^{57}$. Aníbal não ignorava nada do que acontecia, e prestava atenção a todas as movimentaçóes. Entre Cartagineses e Romanos havia uma colina ao meio, que não era difícil de tomar, mas que uma vez ocupada seria uma posição forte para

56 Segundo Políbio (3.103.5-8), Fábio Máximo permitiu que Minúcio escolhesse uma das duas possibilidades e este escolheu a que Plutarco atribui a Fábio. Este relato coincide com Tito Lívio 22.27, mas difere do mesmo no que respeita às escolhas das legióes, pois aquelas que Plutarco atribui a Fábio, são as mesmas que Tito Lívio diz terem sido escolhidas por Minúcio.

${ }^{57}$ Os dados dos capítulos 11 e 12 coincidem com os testemunhos de Tito Lívio 22.28-29 e Políbio, 3.104-105. 
um acampamento e suficiente para todas as precisóes ${ }^{58}$. 2. A planície que a rodeava, vista de longe, parecia uniforme por ser calva e lisa, mas havia nela alguns fossos não profundos e também covas. Apesar de ser possível tomar, com facilidade e de forma secreta, a colina, Aníbal não o quis fazer, mas deixou-a no meio como pretexto para desencadear o combate. 3. Quando viu Minúcio separado de Fábio, espalhou, durante a noite, alguns soldados pelos fossos e pelas $\operatorname{covas}^{59}$, e no dia seguinte enviou ostensivamente náo muitos para tomar a colina, de forma a atrair Minúcio para se encontrarem naquele lugar. 4. E assim sucedeu. Primeiro, este enviou a infantaria ligeira, depois a cavalaria, e, por último, vendo que Aníbal vinha em socorro daqueles que se encontravam na colina, acabou por pôr todo o exército em ordem de batalha.

5. Desencadeou-se um violento combate e os Romanos defendiam-se dos soldados cartagineses que atacavam a partir do alto da colina; o combate permanecia incerto, até que Aníbal, vendo que Minúcio caíra bem na armadilha, e que tinha retaguarda descoberta, vulnerável ao ataque inimigo, fez sinal. 6. Nisto, estes soldados levantaram-se, ao mesmo tempo, de muitos lugares e com gritaria atacaram e foram matando os que estavam nas últimas filas. A desordem e o terror

${ }^{58}$ Para uma versão mais detalhada, vide Políbio 3.104 sqq. e Tito Lívio 22.28 sqq.

${ }^{59}$ Segundo Tito Lívio (22.28), tratava-se de cinco mil cavaleiros e soldados a pé, enquanto Políbio (3.104) faz referência a cinco mil homens armados e outra infantaria, além de quinhentos elementos de cavalaria. 
que se apoderaram dos Romanos eram indescritíveis e a audácia do próprio Minúcio caiu por terra. Ele não fazia mais do deitar um olhar inquieto a cada um dos seus oficiais; nenhum se atrevia a permanecer no seu posto, lançavam-se numa fuga sem salvação possível. 7. Os cavaleiros Númidas, que já dominavam a situaçáo, andavam em círculo na planície e matavam os que fugiam.

12. Os Romanos encontravam-se numa situação de desgraça, mas o perigo não escapou a Fábio. Com efeito, prevendo, como parece, o que ia acontecer, tinha já colocado as suas forças em linha de batalha e providas de armas; preocupava-se em saber o que se passava, não por meio de mensageiros, mas tendo ele próprio uma atalaia diante da paliçada. 2. Quando viu que o exército estava cercado e em desordem e ouviu os gritos daqueles que, não mais resistindo, se lançavam em fuga aterrorizados, bateu na $\operatorname{coxa}^{60} \mathrm{e}$, suspirando profundamente, disse para aqueles que estavam perto de si: "Por Héracles! Como Minúcio se perdeu mais rápido do que eu esperava, mas já tarde para o que foi a sua precipitação!”. 3. Em seguida, mandou o exército desenrolar os estandartes o mais rápido possível, ordenou que o seguissem e gritou: "Agora, soldados, que cada um, recordando Marco Minúcio, corra em sua ajuda, pois é um homem corajoso e um patriota, e se com a sua precipitação em expulsar o inimigo cometeu algum erro, logo the pediremos contas." 4. Com efeito, assim que apareceu, afugentou

${ }^{60}$ Gesto peculiar ao herói homérico. Cf. Ilíada 16.124-5. 
e dispersou os cavaleiros Númidas, que cercavam a planície; atacou depois aqueles que combatiam e estavam na retaguarda dos Romanos e matou aqueles que resistiam; os restantes, por sua vez, antes de sofrer e receber em troca o mesmo que eles tinham infligido aos Romanos, cederam e puseram-se em fuga. 5. Aníbal, vendo a mudança da situação e que Fábio, com um vigor superior à sua idade, empurrando, abria caminho no meio dos combatentes, para subir a colina em socorro de Minúcio, suspendeu o combate. Com a trombeta, deu sinal de retirada, fez voltar os Cartagineses à paliçada e, contentes, regressaram também os Romanos. 6. Diz-se que, na volta, o próprio Aníbal disse aos seus camaradas, em tom jocoso, algo semelhante sobre Fábio: "Náo vos tinha já eu avisado, várias vezes, que essa nuvem que pendia sobre os cumes, um dia, haveria de rebentar em granizo e tempestades?" ${ }^{1}$.

13. Depois da batalha, Fábio despojou todos os inimigos que tinha matado e retirou-se sem proferir palavra alguma, insolente ou ofensiva, sobre o seu colega. Quanto a Minúcio, reuniu o seu exército e 2. disse: "Soldados, o não errar em grandes empresas está acima da condição humana. Contudo, errar e aproveitar os insucessos como lição para o futuro, isso é próprio do homem bom e sensato. 3. Na verdade, eu confesso que se, por alguns motivos, me queixo da fortuna, mais razóes tenho para a bendizer. O que, em tanto tempo, não me dei conta, num instante de um

${ }^{61}$ Cf. Tito Lívio 22.30.10 e Plutarco, Obras Morais 195 D. 
só dia o aprendi: reconheci que não tenho capacidade para mandar nos outros, mas preciso que outro mande em mim, e não devo aspirar a vencer aqueles para quem é mais belo ser derrotado.

4. Para vós, daqui em diante, não haverá outro chefe além do ditador; mas como forma de gratidão para com ele, eu mesmo irei à vossa frente para lhe demonstrar o nosso reconhecimento, assegurando-lhe que serei o primeiro a obedecer-lhe e a cumprir o que ele me ordenar". 5. Depois destas palavras, ordenou que se erguessem as águias e que todos o seguissem, levou o seu exército para a paliçada de Fábio e caminhou em direcção à tenda do general, perante a admiração e espanto de todos. 6. Quando Fábio saiu, Minúcio, colocou diante de si os estandartes e chamou-o de pai em alta voz. Os soldados saudavam os de Fábio como patronos, título que os libertos atribuem a quem os libertou.

7. Feito silêncio, Minúcio disse: "Duas vitórias, ó ditador, conquistaste neste mesmo dia: uma face a Aníbal, pela tua coragem, e outra face ao teu colega pela prudência e bondade. Se com uma nos salvaste, com a outra a todos nos deste uma lição. Vítimas de uma vergonhosa derrota face a Aníbal, mas bela e libertadora face a ti. 8. Como um pai benévolo te saúdo, pois náo tendo outro título mais honroso, já que maior do que a gratidáo devida a um pai é a gratidáo que eu te devo. Daquele recebi apenas a vida, enquanto de ti recebi a salvaçáo, como muitos 
outros $^{62}$ ". 9. Depois destas palavras, acercou-se de Fábio e abraçou-o. O mesmo se via fazerem os soldados: abraçavam-se e beijavam-se uns aos outros, de tal modo que o acampamento estava pleno de júbilo e de lágrimas de alegria ${ }^{63}$.

14. Depois desta campanha, Fábio depôs o cargo e designaram-se novos cônsules ${ }^{64}$. Destes, os primeiros nomeados continuaram a mesma táctica bélica: evitar combater com Aníbal em batalha campal, ir em socorro dos aliados para prevenir revoltas ${ }^{65} .2$. Contudo, quando Terêncio Varrão ${ }^{66}$ foi elevado a cônsul, de família nada ilustre, ficou conhecido pela sua atitude demagógica e temerária. Era evidente que, pela sua inexperiência e excesso de ousadia, iria arriscar, como quem joga um dado, o destino do Estado. Gritava nas assembleias que a guerra ia continuar, enquanto a cidade se servisse de Fábios como generais e que, num mesmo dia, ele veria e venceria os inimigos. 3. Ao mesmo tempo que dizia isto, reunia e alistava um exército táo grande como nunca antes os Romanos tinham utilizado contra nenhum inimigo: oitenta e oito mil ${ }^{67}$ foram os homens dispostos

${ }^{62}$ Estes dois discursos de Minúcio constam já em Tito Lívio 22.29 e 30 .

${ }^{63}$ Cf. Tito Lívio 22.29.7-11 e 30.1-7.

${ }^{64}$ Os cônsules Gneu Servílio Gémino e M. Atílio Régulo recuperam o poder.

${ }^{65}$ Cf. Tito Lívio 22.32.1-3.

${ }^{66}$ Cônsul em 216 a.C. Tito Lívio (22.25) refere que seu pai era talhante e que se ocupava do pequeno comércio.

${ }^{67}$ Políbio 3.107.9 faz referência a oito legióes de 5000 homens cada, às quais se juntaram os aliados. 
para a batalha. Este era um motivo de grande temor para Fábio e para os Romanos sensatos, pois não tinham esperança de que a cidade recuperasse se uma derrota fizesse perder tamanha juventude. 4. Fábio dirigiu-se ao colega de Terêncio, Paulo Emílio, homem de experiência militar que não era grato ao povo e estava receoso em relação à plebe, na sequência de uma condenação que lhe fora atribuída num processo contra o Estado ${ }^{68}$. Fábio incitava-o e encorajava-o a refrear a loucura do colega, 5. Advertiu-o de que a sua luta pela pátria não seria tanto contra Aníbal quanto contra Terêncio, pois apressavam-se ambos para a batalha, um por não estar ciente da força do inimigo e o outro por estar ciente da fraqueza da sua posição. 6. "Eu, Paulo", disse Fábio, "mereço, no que toca à questão de Aníbal, mais crédito do que Terêncio, e asseguro-te que, se ninguém lhe apresentar batalha este ano, ele sucumbirá se permanecer ou fugirá e abandonará a Itália; pois mesmo agora que nos parece ter vencido e dominado a situação, nenhum dos seus inimigos passou para o seu lado e das forças da pátria não sobrará, no total, nem sequer um terço." 7. A isto, dizem que Paulo respondeu: "Para mim, Fábio, se olho pelos meus interesses, é melhor cair debaixo das lanças dos inimigos novamente do que submeter-me

${ }^{68}$ O patrício L. Emílio Paulo foi cônsul em 219 a.C. e obteve o triunfo contra os Ilírios. O seu filho, L. Emílio Paulo da Macedónia, foi o vencedor de Perseu na batalha de Pidna (168 a.C.), sobre o qual Plutarco escreveu uma biografia (Timoleonte - Emílio Paulo). Ele e o seu colega M. Lívio Salinator criticaram os seus chefes pelo facto de os despojos de guerra terem sido mal repartidos. Segundo Tito Lívio 22.35.5, Emílio Paulo não foi condenado, ao contrário do seu colega. 
aos votos dos cidadãos. No entanto, se a República se encontra em tal situaçáo, esforçar-me-ei por parecer a ti um bom general, mais do que a todos os outros, que me pressionam para o contrário." Com estes intentos, partiu Paulo para a guerra ${ }^{69}$.

15. Terêncio, contudo, que se tinha proposto a comandar em dias alternados e estava acampado próximo de Aníbal, junto ao rio Áufido ${ }^{70}$ e à cidade chamada Canas, ao amanhecer lançou o sinal de combate - uma túnica púrpura que se estende sobre a tenda do general - de tal modo que os Cartagineses, a princípio, ficaram perturbados, vendo a ousadia do general e o numeroso exército, enquanto eles não eram nem metade. 2. Aníbal, porém, ordenou às suas forças que pegassem nas armas, subiu a cavalo e, acompanhado de alguns homens, subiu a uma colina para ver os inimigos que se estavam formados em linha de batalha.

3. Um elemento da comitiva de Aníbal, chamado Gíscon $^{71}$, da mesma condição que ele, comentou que the parecia descomunal a quantidade dos inimigos, ao que Aníbal, franzindo a face, retorquiu: "Outra coisa, Gíscon, ainda mais extraordinária te esqueceste de admirar." "Qual?", perguntou Gíscon. "É que, de todos quantos ali estáo", respondeu o general "nenhum se chama Gíscon.” Esta graça tão inesperada fez rir quantos lá estavam, e, descendo a colina, não deixavam de a transmitir a todos os que ali se encontravam, de tal

${ }^{69}$ Cf. Tito Lívio 22.39 e 40, 1-3.

${ }^{70}$ Rio da regiáo de Apúlia, actualmente designado de Ofanto.

${ }^{71}$ Nem Políbio, nem Tito Lívio fazem referência a esta figura. 
forma que a graça passou por muitos e nem a escolta de Aníbal conseguiu ficar séria. 4. A visão de tanto riso encheu os Cartagineses de coragem, que pensaram que, se o seu general dizia piadas em face do perigo, isso era sinal evidente de que o desprezava profundamente ${ }^{72}$.

16. Naquela batalha, Aníbal serviu-se de duas estratégias. A primeira, em relação ao terreno: colocou as suas tropas de forma a que ficasse de costas para o vento, pois um furacão, semelhante a um sopro de fogo, tinha-se desencadeado e levantado, daquelas planícies arenosas e abertas, uma terrível poeira, que se alçava por cima da falange dos Cartagineses contra os Romanos e agredia-lhe as faces, fazendo-os voltar para trás e alterar a formação ${ }^{73}$. 2. A segunda estratégia dizia respeito à forma de dispor as tropas: colocou em ambos os lados do centro aquela que é a parte mais forte e combativa do exército, tendo enchido o centro com as menos capazes, utilizando-os como uma saliência que se destacava do resto da falange. Instruiu as melhores tropas para que, quando os Romanos abrissem um espaço na frente e se precipitassem para o centro, que cedendo pela acção da força deixaria uma reentrância; que eles permanecessem no interior $\mathrm{da}$ falange, voltando-se rapidamente de ambos os lados, os atacassem pelos flancos e os cercassem, fechando a retaguarda. 3. Foi esta manobra, ao que parece, que produziu maior mortandade, já que o centro cedeu e absorveu os Romanos que os perseguiam.

${ }^{72}$ Sobre a dimensão apotropaica do riso, vide Halliwell (2008: 199-201).

${ }^{73}$ Cf. Tito Lívio 22.46.8. 
Nisto, a falange de Aníbal alterou o esquema e adoptou a forma em meia-lua e então os oficiais das melhores tropas, carregando com os seus homens uns à esquerda, outros à direita, lançaram-se sobre os flancos descobertos do inimigo; e, com isto, fecharam no centro e mataram todos os que não se apressaram a fugir daquele enlace.

4. Conta-se também que, à cavalaria dos Romanos, aconteceu um inesperado acidente. Paulo, segundo parece, foi deitado abaixo pelo seu cavalo, que se tinha ferido, e aqueles que estavam perto de si abandonaram os cavalos e foram a pé, a partir de vários sítios, para o socorrem. 5. Quando os cavaleiros viram isto, pensando que se tratava de uma ordem geral, desceram todos do cavalo e lutaram a pé com os inimigos. Deparando-se com tal situação, Aníbal disse "antes isto do que terem-mos entregado atados." ${ }^{44}$ 6. Mas estas coisas são transmitidas por aqueles que escreveram histórias muito pormenorizadas ${ }^{75}$.

Dos cônsules, Varrão chegou a cavalo com alguns à cidade de Venúsia, enquanto que Paulo, entre o abismo e a onda daquela fuga, com o corpo coberto de feridas por causa dos muitos dardos e com o espírito oprimido por tamanho sofrimento, sentou-se junto a uma pedra à espera de receber o golpe de misericórdia dos inimigos ${ }^{76} \cdot 7$. Contudo, por causa da abundância do

${ }^{74}$ Cf. Tito Lívio 22.49.

${ }^{75}$ Aqueles que escreveram relatos mais detalhados são Políbio (3.110-117) e Tito Lívio (22.44-50). Com efeito, no início da vida de Alexandre, Plutarco acentua a diferença estes os dois registos, a biografia, que relata o percurso do indivíduo, e a história, de tema mais amplo.

${ }^{76}$ Cf. Tito Lívio 22.38.6-13. 
sangue, que lhe desfigurava a cabeça e o rosto, muitos não o distinguiam, e amigos e servidores que passaram não o reconheceram. Apenas Cornélio Lêntulo ${ }^{77}$, jovem patrício, o viu e se apercebeu de quem era, desceu do cavalo, acercou-se dele e exortou-o a salvar-se para bem dos cidadãos, que nunca antes precisaram tanto de um bom general. 8. Este, contudo, não aceitou o pedido e obrigou o jovem, apesar das lágrimas, a montar de novo o cavalo e logo, tomando a sua mão direita, levantou-se ao mesmo tempo que ele e disse: "Anuncia, Lêntulo, a Fábio Máximo, e sê tu mesmo testemunha, de que Paulo Emílio permaneceu fiel às suas resoluçôes até ao fim, e que não quebrou nenhum acordo com ele, mas foi vencido primeiro por Varrão e depois por Aníbal.” 9. Com tais instruçôes, despediu-se de Lêntulo, abandonou-se às máos dos seus assassinos e morreu. Conta-se que, nesta batalha, caíram cinquenta mil Romanos, foram feitos prisioneiros quatro mil e que, depois do combate, foram capturados não menos de dez mil em ambos os campos.

17. Depois de tamanha vitória, os amigos de Aníbal incitavam-no a aproveitar a fortuna, a seguir os inimigos em fuga para entrar com eles na cidade e, no quinto dia da vitória, jantar no Capitólio ${ }^{78}$. Com efeito, não é fácil dizer por que razão terá recuado nessa intenção, mas parece que a hesitação e receio foram

${ }^{77}$ Gneu Cornélio Lêntulo era então tribunus militum. Em 201 a.C., seria eleito cônsul e comandante da frota na Sicília.

${ }^{78}$ Cf. Catão, Origens fr. 86 Peter; Tito Lívio 22.51. 
mais obra de algum génio ou deus que o demoveram ${ }^{79}$. 2. Por isso, dizem que o cartaginês Barca, enraivecido, terá comentado: "Tu sabes vencer, mas não sabes tirar proveito da vitória." 80 3. Não obstante, a vitória trouxe uma grande mudança. Antes da batalha, Aníbal não dispunha, em Itália, nem de cidade, nem de mercado ou de porto, e só com dificuldade conseguia providenciar o indispensável ao exército através do roubo; não havia qualquer base firme para empreender uma batalha, senão através da pilhagem e indo de um lado para outro com o exército, como um bando de piratas. Naquela altura, pelo contrário, quase toda a Itália ficou submetida à sua obediência.

4. Na verdade, os povos mais numerosos e importantes a ele aderiram voluntariamente, e até mesmo Cápua, a cidade mais importante depois de Roma, a ele se juntou. Com efeito, uma grande adversidade serve para provar não só, como diz Eurípides ${ }^{81}$, quem são os amigos, mas também os generais sensatos. 5. Assim, o que antes da batalha se pensava ser cobardia e apatia da parte de Fábio, imediatamente a seguir à batalha não parecia já perspicácia humana, mas alguma obra da inteligência celeste ou divina, pois previra com muita antecipação acontecimentos futuros e que mesmo agora pareciam apenas verosímeis para aqueles que os sofriam. 6. Por isso, assim que Roma depositou nele as últimas

${ }^{79}$ Segundo Sílio Itálico 10.337, Juno teria enviado a Aníbal um sonho para o dissuadir de avançar sobre Roma. $2-4$.

${ }^{80}$ Este comentário foi igualmente referido por Tito Lívio 22.51.

${ }^{81}$ Verso de uma tragédia perdida (fr. $993 \mathrm{Nauck}^{2}$ ). 
esperanças e se refugiou na resolução daquele homem como em um templo e altar, foi essa a primeira e principal razáo pela qual a cidade se manteve firme, em vez de dispersar, como sucedeu *** durante a invasão gaulesa. 7. Com efeito, ele que, quando parecia não haver nenhum perigo, se revelava prudente e pessimista, naquela altura, quando todos se tinham entregado a uma dor infinita e ao temor, sem capacidade de reacção, era o único a passear tranquilamente pela cidade com um passo calmo, de aparência serena e falava às pessoas com mansidão. Eliminou os lamentos femininos, eliminou os ajuntamentos dos que se agrupavam em espaços públicos para lamentar as desgraças em comum. Convenceu, o Senado a reunir-se e a inspirar confiança aos magistrados, tornou-se assim a força e o suporte e tinha todos os olhares virados para si.

18. Colocou então vigias nas portas, de modo a evitar que a multidão saísse e abandonasse a cidade, e fixou lugar e tempo para o lamento, permitindo, a quem quisesse, chorar em casa durante trinta dias. Contudo, terminado este período, teria que eliminar todo o lamento e purificar a cidade de tais manifestaçóes, 2. pois as celebraçóes de Deméter ${ }^{82}$ teriam lugar naqueles dias, pelo que pareceu melhor cessar completamente os sacrifícios e a procissão, antes que se evidenciasse a grandeza do desastre com a fraca concorrência e o desalento dos assistentes. Além disso, é também agradável aos deuses ser

${ }^{82}$ Designação correspondente à deusa Ceres. 
honrados por homens contentes ${ }^{83} .3$. Nisto, cumpriu-se tudo quanto os sacerdotes aconselharam para propiciar os deuses e afastar os males. Com efeito, enviou-se também a Delfos, para consultar o oráculo, Pictor ${ }^{84}$, um familiar de Fábio. Quando se descobriu que as duas Vestais se deixaram seduzir, uma foi sepultada viva ${ }^{85}$, conforme o costume, enquanto que a outra, infligiu a morte a si mesma. 4. Contudo, o mais admirável foi a generosidade e a clemência da cidade, quando o cônsul Varrão regressava da sua fuga - tal como regressa alguém que se comporta de forma vergonhosa e lamentável, humilhado e cabisbaixo -, o senado e todo o povo foram, ao seu encontro até às portas da cidade para o receber. 5 . Os magistrados e os principais do Senado, entre os quais se encontrava Fábio, quando se fez silêncio, elogiaramno por náo ter renunciado à cidade depois de tamanho infortúnio e por estar ali presente para desempenhar o seu cargo, por velar pelas leis dos cidadáos e por achar que era ainda possível a salvação ${ }^{86}$.

${ }^{83}$ Cf. Tito Lívio 22.56.4. Tratava-se do sacrum anniversarium Cereris.

${ }^{84}$ Cf. Tito Lívio 22.57.2-6. Trata-se de Fábio Pictor, o primeiro historiador romano. Como membro do Senado, combateu contra os Cartagineses na Segunda Guerra Púnica (218-201 a.C.). Após o desastre de Canas, foi enviado numa embaixada ao oráculo de Delfos em 216 a.C. A sua obra, hoje perdida, relata os primeiros tempos da história de Roma e rapidamente passa para o momento histórico coevo. Escreveu em grego, não só pela qualidade literária desta língua, mas também para defender a política romana no mundo grego. Mais tarde, historiadores como Políbio, Dionísio de Halicarnasso e Tito Lívio recorreram à sua obra como fonte.

${ }^{85}$ Cf. Plutarco, Numa 10.4 sqq.

${ }^{86}$ Cf. Tito Lívio 22.61.14. 
19. Quando souberam que Aníbal, depois da batalha, se tinha afastado para o outro extremo da Itália, ganharam confiança e enviaram outra vez generais e exércitos. Daqueles, os mais ilustres eram Fábio Máximo e Cláudio Marcelo ${ }^{87}$, ambos igualmente admirados, apesar das suas orientaçóes políticas serem quase totalmente opostas.

2. Quanto a Marcelo, como se disse na biografia escrita sobre ele ${ }^{88}$, distinguia-se pela sua acção brilhante e impetuosa, como um homem de braço de ferro e de natureza semelhante àqueles a quem Homero chama sobretudo de "belicosos" e "orgulhosos" 89 ; por isso, travou os seus primeiros combates com uma táctica bélica vigorosa e temerária e, a um homem ousado como Aníbal, opunha igualmente a sua audácia. 3. Fábio, por outro lado, levando em mente os planos iniciais, tinha a esperança de que, se ninguém combatesse ou provocasse Aníbal, ele se prejudicaria a si mesmo e acabaria por desgastar-se com a guerra, como acontece com a energia do corpo de um atleta, quando se submete a um esforço excessivo e exaustivo. 4. Por esta razão, disse Posidónio ${ }^{90}$

${ }^{87}$ Cônsules em 214 a.C.

${ }^{88}$ Cf. Plutarco, Marcelo 1 e 9.

${ }^{89}$ E.g. Iliada 3.36 e 16.65.

${ }^{90}$ FGrHist 87 F 42. Cf. Plutarco, Marcelo 9.7. Posidónio de Apameia (sécs. II-I a.C.), filósofo estóico, escreveu um relato histórico em cinquenta e dois livros, que abarcava acontecimentos desde 146 a.C. até à ditadura de Sila. Considerado o pensador mais influente do Império Romano seria comparável apenas a Aristóteles, superando-o mesmo no que respeitava à unidade sistemática da sua ciência. Representante do Estoicismo médio, foi discípulo de Panécio em Atenas e mestre de ilustres romanos como Cícero e Pompeu. Como é o único autor mencionado nesta 
que os Romanos lhe chamariam $o$ escudo e a Marcelo, $a$ espada e que a firmeza e a segurança de Fábio, misturadas com o ímpeto de Marcelo, eram a salvação dos Romanos. 5. Por um lado, Aníbal confrontando-se muitas vezes com este, como um rio violento, sacudia e aniquilava a sua força; por outro, Fábio, semelhante a um rio que fluía sem ruído e pouco a pouco, consumia continuamente as suas bordas. Assim chegou a um impasse que consistia em perder o ânimo quando lutava com Marcelo e recear Fábio quando com ele não lutava. 6. Em suma, pode dizer-se que a maior parte do tempo se fez guerra contra estes, ora generais, ora procônsules, ora cônsules e cada um deles foi cônsul cinco vezes ${ }^{91}$. Marcelo, porém, durante o seu quinto consulado, caiu numa emboscada e morreu ${ }^{92}$. Fábio, por outro lado, muitas vezes foi alvo de todo o tipo de ardis e provas, mas nada resultou. Excepto uma única vez em que se lhe preparou uma cilada que esteve a ponto de o enganar: 7 . Aníbal forjou umas cartas dos cidadáos mais influentes e poderosos do Metaponto e remeteu-as a Fábio, como se a cidade a ele se fosse entregar caso ele se apresentasse; e aqueles que o pediam esperariam que ele chegasse e que estivesse nas proximidades. 8. Estas cartas convenceram, com

biografia e na de Marcelo, por quatro vezes, é verosímil que tenha sido uma das principais fontes de Plutarco na elaboração da Vida de Fábio Máximo.

${ }^{91}$ Cláudio Marcelo foi eleito cônsul em 222, 215, 214, 210 e 208 a.C., enquanto que Fábio granjeara essa distinção em 233, 228, 215, 214 e 209 a.C., tal como o seu bisavô, Q. F. Máximo Ruliano.

${ }^{92}$ Em 208 a.C. na Lucânia. Vide Plutarco, Marcelo 29. Cf. Tito Lívio 27.26-27. 
efeito, Fábio, e estava disposto a actuar durante a noite com uma parte do exército. Contudo, como o vaticínio do voo das aves não foi favorável, desistiu. Em pouco tempo se descobriu que a carta a ele dirigida tinha sido escrita por Aníbal para o enganar, e que este o aguardava numa armadilha ao pé da cidade. Este sucesso, porém, teríamos de o atribuir ao favor dos deuses ${ }^{33}$.

20. Em relação ao afastamento das cidades e das revoltas dos aliados, Fábio pensava que deviam ser controlados e trazidos de volta à razão de forma suave e afável, antes de investigar qualquer suspeita ou ser demasiado severo para com os suspeitos. 2. Diz-se que, ao saber que um soldado marso ${ }^{94}$, o primeiro entre os aliados na bravura na linhagem, tinha falado de revolta com alguns do acampamento, Fábio não se irritou com ele, antes admitiu que o seu mérito não tinha sido reconhecido e disse, naquele momento, que a culpa era dos generais por distribuírem as recompensas conforme os favores e não de acordo com o mérito; mas que daí em diante, seria ele o culpado se não the manifestasse a sua vontade e a ele não recorresse quando tivesse alguma reclamação. 3. Dito isto, ofereceu-lhe um cavalo de guerra e distinguiu-o com outros prémios de valor, de forma que, a partir de então, aquele homem foi um

${ }^{93}$ Este episódio data do ano 209 a.C. Tito Lívio (27.16.9-16) apresenta um testemunho mais completo, referindo que a armadilha tinha sido confessada pelos próprios habitantes de Metaponto que vieram pedir que Fábio se aproximasse da cidade.

${ }^{94}$ Valério Máximo (7.3.7) refere que se trata de um soldado originário de Nola de nome Mário Estatílio. Vide também Sobre os varöes ilustres 43.5; Frontino 4.7.36. 
modelo de lealdade e zelo. 4. Com efeito, Fábio achava incompreensível que os criadores de cavalos e de cáes de caça recorressem a cuidados, atençóes e à alimentação, mais do que a açoites e coleiras, para retirar aos animais a aspereza, o temperamento selvagem e a rebeldia. Aquele que governa os homens, pelo contrário, não faz da benevolência e da mansidão o meio principal para corrigir os defeitos, mas age com mais dureza e violência do que aquela com que os camponeses tratam as figueiras, pereiras e oliveiras selvagens, quando as cultivam e as convertem em oliveiras, pereiras e figueiras mansas, respectivamente ${ }^{95}$. 5. Os oficiais informaramno sobre outro homem de origem lucana que fugira do acampamento e abandonara muitas vezes o seu posto. Fábio perguntou-lhes como era ele visto em tudo o resto. 6. Com efeito, todos testemunharam que não seria fácil encontrar outro soldado igual, ao mesmo tempo que lhe contavam algumas das suas notáveis proezas e façanhas. Questionou, então, a causa da sua indisciplina e descobriu que, por estar dominado pelo amor a uma mulher, se arriscava a fazer grandes caminhadas longe do acampamento, de cada vez que a visitava. 7. Enviou alguns, sem que ele o soubesse, e fazendo vir a mulher, esconderam-na na tenda. Chamou, em seguida, o lucano em privado e disse-lhe: "Não ignoro o facto de, contrariamente às tradiçóes e leis romanas, teres pernoitado muitas vezes fora do acampamento, mas

${ }^{95}$ A mesma ideia aparece expressa em Plutarco, Obras Morais 492 E-F. A doçura e a tolerância são qualidades peculiares tanto a Fábio como a Péricles, algo que será bem evidenciado na comparaçáo final. 
também não ignoro o facto de seres um bom soldado. 8 . Assim, que sejam as tuas faltas compensadas pelas tuas proezas, e daqui em diante, colocarei a tua vigilância a cargo de outra pessoa." 9. E, perante o espanto do soldado, mandou sair a jovem e entregou-a aos seus braços, dizendo: "É esta a minha garantia de que vais permanecer no acampamento connosco. Tu, com o teu trabalho, demonstrarás se nos abandonas por alguma outra maldade e se o amor e esta mulher eram apenas um pretexto que usavas." É o que contam sobre estes episódios ${ }^{96}$.

21. Fábio tomou ainda a cidade dos Tarentinos por meio de traição ${ }^{97}$, conquistando-a da seguinte maneira: um jovem tarentino do seu exército tinha, em Tarento, uma irmã que lhe dedicava grande lealdade e afecto. 2. Estava apaixonado por ela um brútio ${ }^{98}$ que integrava a guarnição encarregada por Aníbal de manter a cidade sob o seu controlo; esta situaçáo criou no tarentino a expectativa de um plano e, com o conhecimento de Fábio, regressou à cidade dizendo que tinha desertado para se juntar à irmá. Os primeiros dias decorreram e

${ }^{96}$ Vide Plutarco, Obras Morais 195 E, Valério Máximo 7.3.7, Sobre os varóes ilustres 43.5

${ }^{97}$ Em 209 a.C. Cf. Tito Lívio 27.15.9-11. Aníbal tinha conquistado Tarento em 212 a.C. O domínio, contudo, nấo foi absoluto, pois a acrópole manteve uma guarniçâo romana. Durante esse mesmo ano, Aníbal tomara aliás quase todas as cidades do Golfo de Tarento.

${ }^{98}$ Brútio corresponde à periferia da actual Calábria. Este foi o último refúgio de Aníbal em Itália, que lhe valeu uma severa punição da parte dos Romanos, depois da vitória. 
o brútio ficava em casa, pois pensava que o irmão náo estava inteirado da relação deles. 3. Nisto, o jovem disse à irmã: "Circulava por aí, com frequência, o boato de que tu mantinhas relaçóes com um homem de influência e poderoso. De quem se trata? Se se trata, como dizem, de alguém bem conceituado e distinto, não importa a origem, pois a guerra tudo confunde. Além disso, com a necessidade nada é vergonhoso, mas é, pelo contrário, uma sorte no momento em que a justiça não tem força, ser tratado com benevolência por quem tem mais poder." 4. Em sequência disto, a mulher mandou vir o brútio e apresentou-lhe o seu irmão. Este, por sua vez, favorecendo a paixão do bárbaro e parecendo-lhe ficar a sua irmã mais apaixonada e submissa do que antes a seu respeito, ganhou a sua confiança a ponto de, sem dificuldade, conseguir mudar o pensamento de um homem apaixonado e mercenário com a expectativa das grandes recompensas que, segundo este lhe dizia, Fábio lhe oferecia. 5. É esta a versão, com efeito, que a maioria dos autores tem escrito sobre este tema ${ }^{99}$. Alguns, contudo, defendem que a mulher pela qual brútio mudou de ala não era tarentina de nascimento, mas antes brútia, e ainda que ela seria concubina de Fábio. Ao tomar conhecimento de que o chefe dos Brútios era concidadáo e conhecido seu, revelou-o a Fábio e, numa conversa que teve com ele ao pé da muralha, conseguiu convencer e vencer o homem por completo ${ }^{100}$.

${ }^{99}$ Vide Tito Lívio 27. 15. 9-11.

100 Não se conhecem outros testemunhos que atestem esta versão. 
22. Enquanto decorriam estes factos, Fábio engendrou algo para distrair Aníbal; ordenou aos soldados que estavam em Régio para fazer uma incursão por Brútia e acampar junto a Caulónia de forma a tomála pela força. Os soldados, cerca de oito mil, eram na sua maioria desertores e os mais inúteis dos proscritos entre os homens enviados por Marcelo da Sicília, pelo que a sua morte traria menos dor e prejuízo à cidade ${ }^{101} .2$. Ele esperava que, enviando-os a Aníbal, pudesse afastálo de Tarento, algo que, de facto, aconteceu, pois logo Aníbal se lançou a persegui-los com as suas forças ${ }^{102} .3$. No sexto dia desde que Fábio acampou em Tarento, o jovem, que antecipadamente entrara em acordo com o brútio, veio de noite com a irmá à sua presença, pois conhecia com exactidão e tinha marcado o lugar onde, estando de vigia, o brútio se ia entregar e render-se aos atacantes. 4. Fábio, porém, fez com que a empresa não dependesse unicamente da traição; ele apresentou-se no lugar combinado e manteve-se calmo, enquanto que o resto do exército assaltava as muralhas a partir da terra e do mar, ao mesmo tempo que se fazia uma grande gritaria e se gerava confusão. Nisto, enquanto a maior parte dos Tarentinos acorria em socorro e lutava contra os que assaltavam a muralha, o brútio indicou a Fábio o momento oportuno, este subiu a uma escada e tomou a cidade. 5. Parece, porém, que nesta altura terá sido dominado pelo desejo de glória, pois mandou decapitar os Brútios importantes, de modo a evitar que

101 Segundo Tito Lívio 23.25.7, estes soldados desertores provinham, na sua maioria, de Canas.

${ }^{102}$ Cf. Tito Lívio 27.12.4-6. 
se descobrisse que tinha tomado a cidade por meio de uma traição. Contudo, não obteve o efeito esperado, recebendo pelo contrário a acusação de deslealdade e crueldade $^{103}$. 6. Morreram também muitos Tarentinos e venderam-se trinta mil, o exército saqueou a cidade e foram enviados para o tesouro público três mil talentos. 7. Diz-se que, quando todos estavam a roubar e a levar bens, o secretário de Fábio perguntou-lhe quais eram as suas ordens em relação aos deuses, referindo-se deste modo a quadros e estátuas. Fábio, perante isso, respondeu: "Deixemos aos Tarentinos os seus deuses irritados"104. 8. Contudo, levou consigo de Tarento a estátua colossal de Héracles que colocou no Capitólio, ao lado da qual erigiu uma estátua sua equestre em bronze. Nisto se mostrou mais extravagante que Marcelo, ou melhor, fez com que aquele varão fosse mais admirado pela sua clemência e humanidade, como se escreveu na sua biografia.

23. Diz-se que Aníbal veio em socorro, mas terá ficado a uma distância de quarenta estádios, e que disse em público: "Havia, sem dúvida, algum outro Aníbal entre os Romanos; pois perdemos a cidade de Tarento da mesma forma como a ganhámos"105. E em particular, reconheceu, pela primeira vez, perante os seus companheiros, que, depois de muito tempo, via que seria

${ }^{103}$ Cf. Tito Lívio 27.15.9-16.6.

${ }^{104}$ Este comentário de Fábio consta igualmente em Tito Lívio 27.16.7-8.

${ }^{105}$ Cf. Plutarco, Obras Morais 195 F; Tito Lívio 27.16.10; Cícero, O Orador 2.273; Da Velhice 11. 
difícil para eles, mas que agora lhe parecia impossível apoderar-se de Itália naquelas circunstâncias.

2. Este segundo triunfo, celebrou-o Fábio com mais pompa do que o primeiro ${ }^{106}$. Viam-no agora como um bom atleta que, lutando com Aníbal, facilmente se liberta dos ataques do adversário, como se a presa e seu nó não tivessem já o mesmo vigor de outrora. 3. Com efeito, parte das suas forças estava deslumbrada pelo luxo e pelas riquezas, enquanto que a outra estava debilitada e esgotada por causa dos contínuos combates. Havia um certo Marco Lívio ${ }^{107}$, que comandava a guarnição de Tarento quando Aníbal conseguiu que esta desertasse. Ocupou entáo a acrópole que continuou a proteger sem ser expulso dela, vigiando-a até que os tarentinos voltassem a cair novamente nas mãos dos Romanos.

4. A este importunavam-no as honras que se prestavam a Fábio, e um dia, movido pela inveja e pela ambição, disse perante o Senado que não era Fábio, mas ele próprio, o responsável pela conquista de Tarento. Fábio, rindo-se, disse: "Tens razão! Pois se não tivesses perdido a cidade, eu não a teria recuperado.” ${ }^{108}$.

${ }^{106} \mathrm{O}$ primeiro triunfo conquistado foi sobre os Lígures, referido anteriormente em 2.1.

${ }^{107}$ Cf. Tito Lívio 27.25.34 e Plutarco, Obras Morais 195 F.

108 Referido em Marcelo 21.4. Afirma Plutarco que Marcelo levara para Roma, a maior parte das estátuas e objectos artísticos e que com eles desfilou no cortejo do triunfo. Cf. Tito Lívio 27.16.8 que estabelece a mesma comparação, mas manifesta preferência pela conduta de Fábio, pois Marcelo tinha saqueado Siracusa e levado vários tesouros artísticos. 
24. Os Romanos, além das várias honras que concederam a Fábio, nomearam cônsul o seu filho Fábio $^{109}$. Quando tomou posse do cargo e estava ocupado com um certo assunto relacionado com a guerra, o seu pai, seja por velhice seja por debilidade ou para por o filho à prova, aproximou-se dele montado a cavalo entre aqueles que ali se encontravam e rodeavam o cônsul. 2 . $\mathrm{O}$ jovem vendo-o ao longe, não o permitiu, e mandou um lictor que ordenasse ao seu pai que desmontasse e se apresentasse pelo próprio pé, se tinha algo a pedir ao cônsul. 3. A todos os outros importunou a ordem, e olharam para Fábio em silêncio, como se tivesse sido alvo de um tratamento indigno. Aquele, contudo, rapidamente se desceu do cavalo e acelerou o passo em direcção ao seu filho e, abraçando-o e beijando-o, disse: 4. "Filho, pensas e procedes bem. Pois conheces aqueles em que mandas e a grandeza do cargo que recebeste. Assim foi como nós próprios e os nossos antepassados engrandecemos Roma, colocando sempre os pais e filhos em segundo lugar, depois do bem da pátria." ${ }^{110}$.

5. Na verdade, diz-se que o bisavô de Fábio ${ }^{111}$ era um homem muito conceituado e influente entre os Romanos, pois foi cinco vezes cônsul e celebrou triunfos das maiores guerras. Quando, porém, já velho, partiu com o filho para a guerra, fez a entrada numa quadriga

${ }^{109}$ No ano de 213 a.C., juntamente com Tibério Semprónio Graco. Sobre o combate do filho de Fábio em Arpos, vide Frontino, Estratagemas 3.9.2.

110 Cf. Plutarco, Obras Morais 196 A; Tito Lívio 24. 44. 9; Valério Máximo 2. 2. 4.

111 Este episódio refere-se a Fábio Máximo Ruliano, já mencionado em 1.3. 
no desfile triunfal, seguindo-o com o seu cavalo e com os outros elementos da comitiva ${ }^{112}$. Disto se orgulhava, porque ele, apesar de ter sob o seu filho o poder paternal ${ }^{113}$ e ser considerado o mais importante entre os cidadãos, estava subordinado à lei e àquele magistrado. 6. Com efeito, nem só por isto aquele foi admirável. Aconteceu falecer o filho de Fábio, e ele suportou com muita contenção a desgraça, como um homem prudente e bom pai. Ele mesmo pronunciou, da tribuna do foro, o elogio que nos enterros de individualidades ilustres compóem os familiares e, redigindo o discurso, publicou-o.

25. Cornélio Cipiáo, que tinha sido enviado à Hispânia, expulsou os Cartagineses, depois de os vencer em muitas batalhas e de conseguir para os Romanos muitos povos, grandes cidades e brilhantes empresas, regressando enquanto detentor de popularidade e glória como nenhum outro. Nomeado cônsul ${ }^{114}$, apercebeuse de que o povo pedia e esperava dele uma façanha. Pareceu-lhe muito antiquado e obsoleto continuar a ofensiva contra Aníbal em Itália, pelo que planeava

${ }^{112}$ Cf. Valério Máximo 5.7.1. Este episódio teve lugar durante o primeiro consulado do seu filho Q. Fábio Cruges, avô de Fábio Máximo, em 292 a.C.

${ }^{113}$ Trata-se da patria potestas, que estabelecia que o paterfamilias tinha o direito de vida e de morte sobre os filhos.

${ }^{114}$ Em 205 a.C. a estratégia romana consistiu em invadir a Hispânia de forma de impedir a renovação do exército de Aníbal em Itália, retirando-lhe assim as suas bases de apoio. Como tal, a conquista e presença romanas na Hispânia resultaram de uma manobra defensiva contra Cartago. 
navegar directamente para Cartago e para a Líbia, enchendo-as de armas e exércitos, e transferir a guerra de Itália para esse lugar, incitando o povo com todas as suas forças a executar este plano. 2. Fábio infundia todo o tipo de medos na cidade, como se fosse levada por um homem insensato e jovem ao mais extremo e grave perigo. Náo poupava palavras ou acçóes para afastar os cidadãos destes projectos, e ia conseguindo convencer o Senado. Contudo, ao povo parecia-lhe que estava contra Cipião por inveja dos seus êxitos e que temia que, se ele realizasse alguma façanha grande e notável, terminaria definitivamente com a guerra ou a afastaria de Itália, e ele pareceria uma pessoa indolente e cobarde por náo ter concluído a guerra em tanto tempo.

3. Com efeito, é provável que o propósito inicial de se opor a estes planos se tenha devido mais à segurança e à prudência, pois temia o perigo que este constituía. Contudo, tornou-a uma questáo pessoal e foi mais longe, arrastado por uma certa ambição e sede de vencer, de modo a impedir o engrandecimento de Cipião. A verdade é que fazia o possível para convencer Crasso, colega de Cipião no consulado, para que não autorizasse a expedição nem cedesse, a não ser que, se assim decidisse, que navegasse ele mesmo contra os cartagineses. Além disso, também não deixou que se aprovassem os fundos para a guerra.

4. Deste modo, Cipião vendo-se obrigado a arranjar, por sua própria conta, o dinheiro, reuniu das cidades na Etrúria aquelas que se encontravam numa relação de amizade para com ele e disponíveis para 
comparecer. Quanto a Crasso, permaneceu na sua pátria, por um lado pela sua natureza tranquila e pouco conflituosa $^{115}$, e por outro por respeito à lei divina, pois era Pontífice Máximo.

26. Então, Fábio voltou a opor-se a Cipião por outra via: impedia os jovens que se queriam alistar com ele e retinha-os, gritando nas reunióes do Senado e nas assembleias que Cipião tinha, não só tentado escapar a Aníbal, como também pretendia sair de Itália, levando com ele o exército que ali estava, seduzindo a juventude com esperanças e convencendo-os a abandonar os seus pais, as suas mulheres e a sua cidade, no momento em que o inimigo, vitorioso e imbatível, estava às suas portas. 2. Com estes discursos assustou os Romanos, que decretaram, por votação, que Cipião só iria fazer uso dos exércitos que estavam na Sicília e que não levaria mais do que trezentos dos que tinham estado com na Hispânia e nos quais depositava especial confiança. Esta política de Fábio estava em conformidade com a sua natureza.

3. Contudo, depois de Cipião passar a Líbia ${ }^{116}$, começaram a chegar a Roma notícias das suas notáveis acçóes e façanhas, que se destacavam pela sua grandeza e beleza extraordinárias ${ }^{117}$. Estas notícias foram confirmadas pela chegada de muitos despojos e de um

115 Os discursos pronunciados por Fábio Máximo e Cornélio Cipião diante do Senado foram relatados por Tito Lívio 28.40-45. ${ }^{116}$ Em 204 a.C.

117 Trata-se da batalha nos Campi Magni. 
rei dos Númidas cativo ${ }^{118}$. Soube-se também que dois acampamentos foram destruídos e incendiados num único dia e que com eles arderam muitos homens, muitas armas e cavalos. Chegaram também a Aníbal embaixadas de Cartagineses, chamando-o e pedindolhe que abandonasse aquelas vãs esperanças e fosse em socorro da sua pátria ${ }^{119}$. Por causa de tais sucessos, em Roma, não havia ninguém que não falasse no nome de Cipião. Apesar disso, Fábio exigiu o envio de um substituto para Cipiáo, e, não alegando mais nenhum pretexto, foi dizendo o que já tinha sido dito, que era arriscado confiar assuntos tão importantes a um só homem, pois é difícil que a mesma pessoa seja sempre afortunada. Com ele se incompatibilizou o povo que o considerava já um homem intratável e invejoso, que com a velhice se tornara muito cobarde e pessimista, e que se assustava com Aníbal além da medida.

4. Com efeito, nem sequer depois de Aníbal se fazer ao largo com as suas forças e abandonar a Itália ${ }^{120}$, deixou livre de medos e segura a alegria e a confiança dos cidadãos; pelo contrário, repetia que a conjuntura era frágil e que a cidade corria perigo extremo, pois na Líbia, diante de Cartago, Aníbal cairia sobre eles com todo o seu peso $^{121}$ e colocaria diante de Cipiáo um exército ainda quente com o sangue de numerosos

118 Plutarco não respeita aqui a cronologia dos acontecimentos: os campos cartaginês e númida foram incendiados antes da prisão Sífax, o rei númida.

${ }^{119}$ Cf. Tito Lívio 30.19.

${ }^{120}$ Em 203 a.C. Cf. Tito Lívio 30.26.

${ }^{121}$ Cf. Tito Lívio 28.42.18. 
generais, ditadores e cônsules. A cidade voltou, por isso, a ficar perturbada com estes discursos e, apesar de a guerra ter sido trasladada para a Líbia, parecia que o perigo estava ainda mais próximo de Roma.

27. Pouco tempo depois, Cipião, porém, vence Aníbal numa batalha ${ }^{122}$ e além de derrubar e pisar o orgulho de Cartago definitivamente caído, concede aos seus concidadãos uma alegria maior que toda a esperança e a hegemonia de Roma, realmente

sacudida por uma grande agitação, voltou a erguê-la ${ }^{123}$.

2. Fábio Máximo, contudo, não viveu o suficiente para ver o fim da guerra, não teve conhecimento da derrota de Aníbal, nem pôde contemplar a grande e sólida prosperidade da pátria, pois por volta da altura em que Aníbal zarpava de Itália, ficou doente e morreu ${ }^{124}$.

3. A Epaminondas ${ }^{125}$, enterraram-no os Tebanos a expensas do Estado por causa da sua pobreza, pois, na altura da sua morte, dizem que acabou por não se encontrar nada à excepção de uma moeda de ferro. 4. A Fábio, os Romanos não realizaram o funeral a expensas

${ }^{122}$ A batalha de Zama, que pôs fim à Segunda Guerra Púnica, teve lugar em Outubro de 202 a.C. A vitória de Cipião, nesta batalha, valeu-lhe o título de "Africano".

123 Sófocles, Antígona 163.

${ }^{124}$ Em 203 a.C. Cf. Tito Lívio 30.26.7.

125 Plutarco também escreveu a vida de Epaminondas, famoso general, responsável pela hegemonia tebana no século IV a.C., que venceu os Espartanos em Leuctras e morreu na batalha de Mantineia em 371 a.C. Esta Vida de Plutarco, contudo, não chegou até nós. 
da República, mas cada particular contribuiu com a mais pequena das moedas, não por falta de ajuda por causa da sua pobreza, mas porque o povo o enterrou como a um pai ${ }^{126}$. Assim, a sua morte recebeu a honra e a glória que o distinguiam em vida. 


\section{COMPARAÇÁO ENTRE PérICles e FÁBIo MÁXIMO}


(Página deixada propositadamente em branco) 
28 (1) Eis a história das vidas destes homens ${ }^{1}$. Como ambos deixaram muitos e belos exemplos de virtude política e militar, tomemos em primeiro lugar aquele relativo aos méritos militares. Por um lado, Péricles governou um povo que se encontrava na maior prosperidade, muito grande por si mesmo e no cume do poder, pelo que podia parecer que se manteve até ao final seguro e intacto devido ao bem-estar comum e à força do Estado. As acçóes de Fábio, por outro lado, que recebeu a cidade nas circunstâncias de maior infortúnio e mais lamentáveis, não puderam garantir a segurança, mas soube erguer a cidade a partir da desgraça e melhorar a sua situação. 2. Além disso, as façanhas de Címon, os troféus de Mirónides e de Leócrates e os numerosos e grandiosos sucessos de Tólmides, serviram a Péricles mais para engrandecer a cidade com festas e solenidades do que para fazer guerra e salvaguardar o império.

3. Fábio, porém, assistiu a muitas fugas e derrotas, a muitas mortes e assassínios de generais em pleno poder e pretores, a lagos, planícies e bosques cheios de cadáveres de soldados e rios que corriam

${ }^{1}$ Plutarco identifica semelhanças éticas entre Péricles e Fábio Máximo, como a moderação, a tolerância em relação à maledicência dos seus pares e do povo. $\mathrm{O}$ facto de os inimigos, quando saquearam a cidade, terem respeitado apenas as suas propriedades; o não serem supersticiosos; a prudência antes de avançar para uma batalha, bem como o facto de resistirem com dignidade à morte dos seus familiares. 
para o mar com sangue e morte. Assim, tomando em seu poder a cidade, não permitiu, pela sua força e constância, que se destruísse totalmente, arrastada pelos erros dos outros. 4. Com efeito, pode parecer que, ao homem sensato, não é tão difícil exercer poder sobre uma cidade, humilhada em circunstâncias ruinosas, e torná-la obediente pela necessidade quanto refrear o povo quando está excitado por um sucesso, cheio de orgulho e temeridade. E foi sobretudo desta maneira que Péricles revelou aos Atenienses a sua superioridade. 5. Contudo, a magnitude e o número dos flagelos que então se abateram sobre os Romanos revelou Fábio como homem de decisão e grandeza de carácter que náo se deixou abalar nem abandonou as convicçóes que orientaram a sua conduta.

29 (2) A conquista de Samos por Péricles pode comparar-se à tomada de Tarento e à de Eubeia, por Zeus, à das cidades da Campânia, com excepção de Cápua, que foi conquistada pelos cônsules Fúlvio e Ápio $^{2}$. Náo parece que Fábio tenha vencido numa batalha campal, à excepção daquela com a qual obteve o primeiro triunfo ${ }^{3}$, enquanto que Péricles ergueu nove troféus por vitórias conseguidas aos inimigos em terra e no mar. 2. De Péricles também não se relata nenhuma façanha semelhante àquela que realizou Fábio quando livrou Minúcio de Aníbal e conseguiu salvar, completo, um exército de Romanos, pois foi uma magnífica acção

${ }^{2}$ Em 212 a.C.

3 Trata-se do triunfo sob os Lígures, já mencionado em Fábio Máximo 2.1. 
e nela participaram, ao mesmo tempo, a coragem, a prudência e a bondade. Do mesmo modo, não se relata qualquer erro de Péricles como a derrota que sofreu Fábio quando se deixou enganar por Aníbal com estratagema dos bois: depois de ter apanhado o inimigo, que avançou pelos desfiladeiros por acaso e espontaneamente, deixou-o, sem dar conta, escaparse durante a noite, e no dia seguinte, recorre à força e antecipa-se a quem já estava para o fazer e é derrotado quando já o tinha nas mãos ${ }^{4}$.

3. Contudo, se um bom general deve não só guiar-se pelo presente, mas também prever sensatamente o futuro, para os Atenienses a guerra terminou tal como Péricles tinha previsto e predito: por estarem envolvidos em demasiadas frentes, deitaram a perder a sua hegemonia.

Os Romanos, por outro lado, ao enviarem, contra os planos de Fábio, Cipião contra os Cartagineses, tornaram-se donos de tudo, não por acaso, mas graças à habilidade e à coragem do seu general que venceu os inimigos. Nesta medida, para aquele os fracassos da pátria foram o testemunho de que as suas previsóes estavam correctas, enquanto que para este se provou, pelos êxitos, que estava completamente errado. 4. De igual modo erra um general quando cai em desgraça sem o esperar, como o que deixa passar a oportunidade de um êxito por desconfiança. Com efeito, segundo parece, somente a inexperiência produz a temeridade e suprime a audácia. Eis os factos sobre as questóes bélicas.

${ }^{4}$ Vide capítulos 6 e 7. 
30 (3) No âmbito político, a grande acusação contra Péricles era a guerra. Diz-se, com efeito, que foi ele quem a suscitou por se opor a qualquer concessão aos Lacedemónios. Parece-me a mim que nem Fábio Máximo teria feito qualquer concessão aos Cartagineses, antes teria, com nobreza, enfrentado o perigo para assegurar a hegemonia. 2. Certamente que a bondade e a amabilidade de Fábio para com Minúcio são a condenação das intrigas contra Címon e Tucídides, homens nobres e aristocratas que, por acção de Péricles, foram votados ao ostracismo e ao desterro. Contudo, a influência e o poder de Péricles foram, indubitavelmente, maiores. 3. Com efeito, não deixou que nenhum outro general atirasse a cidade para a desgraça com más resoluçóes. Somente Tólmides lhe escapou, rejeitando veementemente a sua influência, e sofreu uma derrota com os Beócios ${ }^{5}$; todos os outros aderiram e alinharam com o seu parecer por causa da sua grande autoridade.

4. Quanto a Fábio, apesar de ser seguro e infalível, não foi capaz de controlar os que cometeram os erros, pelo que parece inferior a Péricles. A verdade é que os Romanos não teriam sofrido tamanhas derrotas se Fábio tivesse sido tão influente entre os Romanos quanto o foi Péricles em Atenas.

5. Em relação à grandeza de espírito perante as riquezas, um manifestou-a ao não aceitar nada do que lhe ofereciam, enquanto o outro ao dar muito àqueles que lhe pediam, quando libertou, com o seu próprio

${ }^{5}$ Em 447 a.C. na batalha de Coroneia. 
dinheiro, os prisioneiros; 6. é verdade que neste caso a soma não era elevada, apenas seis talentos ${ }^{6}$. Contudo, de Péricles não se pode dizer, com segurança, quanto proveito e favor terá recebido de aliados e reis, graças à sua influência, mas manteve-se absolutamente íntegro e sem mácula.

7. Quanto à grandeza dos monumentos e templos e à magnificência das edificaçôes com que Péricles embelezou Atenas, não são dignos de comparação nem com todos os monumentos juntos de Roma antes dos Césares, pois a grandeza e a elegância das obras de Péricles são superiores àquelas e não consentem comparação.

${ }^{6}$ Em função do que se disse em 7. 5-6, Plutarco estaria a referirse a dez talentos. 


\section{Bibliografia}

\section{EDIÇÕES, TRADUÇÓES E COMENTÁRIOS}

Aavv. (1948), Eneas Tactico. Asclepiodotus. Onasander, Harvard, Mass.

Burnet, J. (1903), Platonis Opera, Oxford.

Bywater, I. (1963), Aristotelis. Ethica Nicomachea, Oxford.

Caeiro, A. C. ('2009), Aristóteles. Ética a Nicómaco, Lisboa.

Campos, J. A. S. (2004), Lúcio Aneu Séneca. Cartas a Lucílio, Lisboa.

Chambers, M. (1986), Aristotelis Athenaion Politeia, Lipsiae.

Crespo, E. ( $\left.{ }^{4} 2007\right)$, Plutarco. Vidas Paralelas. PericlesFabio Máximo, Madrid.

De Romilly, J. (1962), Thucydide. La Guerre du Péloponnèse, Paris.

Diels, H. (1964), Theophrasti Caracteres, Oxford.

Fialho, M. C., Dias, P. B., Silva, C. C. (2001), Plutarco. A Coragem das Mulheres, Coimbra.

Flacelière, R., Chambry, E. (1964), Plutarque. Vies, tomo III: Périclès-Fabius Maximus, Paris.

Foulon, E., WeIl, R. (1990), Polybe. Histoires: livre X et livre XI, Paris. 
Lourenço, F. (2005), Homero. Iliada, Lisboa.

Meiggs, R., LewIs, D. (1969), A Selection of Greek Historical Inscriptions to the End of Fifth Century B. C., Oxford.

Pérez Jiménez, A. (1996), Plutarco. Vidas Paralelas, vol. II: Péricles. Fabio Máximo, Madrid.

Perrin, B. (1967), Plutarch's Lives, vol. III: Pericles and Fabius Maximus, Harvard, Mass.

Podlecki, A. J. (1987), Plutarch. Life of Pericles, Bristol.

Pulquério, M. O. (1997), Platão. Górgias, Lisboa.

Ribeiro, A. (2002), Os heróis de Thomas Carlyle, Lisboa.

Ribeiro Ferreira, J. (1997), Platão. Fedro, Lisboa.

Rocha Pereira, M. H. (52005), Romana: antologia da cultura latina, Lisboa. ( $\left.{ }^{10} 2007\right)$, Platão. A República, Lisboa.

Rodhes, P. J. (1981), A Commentary on the Aristotelian Athenaion Politeia, Oxford.

Santoni, A. (1991), Plutarco. Vite Parallele - Pericle, Milano.

Scott-Kilvert, I. (1960), The Rise and Fall of Athens: nine Greek lives by Plutarch, London. 
Silva, M. F. S. (1980), Aristófanes. Os Acarnenses, Coimbra.

_ (1999), Teofrasto. Os Caracteres, Lisboa.

Stadter, P. A. (I989), A Commentary on Plutarch's Pericles, Chapel Hill and London.

Tod, M. N. (1948), A Selection of Greek Historical Inscriptions, vol. 2, From 403 to 323 B. C., Oxford.

Tricot, J. (1967), Aristote. Ethique d̀ Nicomaque, Paris.

Ziegler, K. (1959), Plutarchi Vitae Parallelae, Leipzig.

\section{Estudos SOBRe PérICLes:}

Ameling, W. (1985), "Plutarch, Perikles 12-14", Historia 34, pp. 47-63.

Andrewes, A. (1978), "The Opposition to Pericles", JHS 98, pp. 1-8.

Barbu, A. N. (1933), Les Procédés de la Peinture des Caractères et la Verité Historique dans les Biographies de Plutarque, Paris.

Boardman, J. et alii ( $\left.{ }^{2} 1988\right)$, The Cambridge Ancient History, vol. IV - Persia, Greece and the Western Mediterranean c. 525 to 479 B. C., Cambridge. 
Breebart, A. B. (1971), "Plutarch and the Political Development of Pericles", Mnemosyne ser. 424 , pp. 260-272.

Brenk, F. (1975), “The Dreams of Plutarch's Lives", Latomus 34, pp. 336-349.

Bury, J. B. et alii ( 11969$)$, The Cambridge Ancient History, vol. V - Athens 478-401 B. C, Cambridge.

Canfora, L. (1995), "Il Pericle di Plutarco: Forme del Potere Personale", in I. Gallo, B. Scardigli (eds.), Teoria e Prasi Politica nelle Opere di Plutarco, Napoli, 1995, pp. 83-90.

Cawkwell, G. L. (1975), “Thucydides Judgment of Periclean Strategy", YCIS 24, pp. 53-70.

Cromey, R. D. (I982), “Pericles' Wife: Chronological Calculations”, GRBS 23, pp. 203-212.

Davison, J. A. (I958), "Notes on the Panathenaea", JHS 78, pp. 23-42.

De Romilly, J. (I988), "Plutarch and Thucydides or the Free Use of Quotations", Phoenix 42, pp. 2234.

De Sainte Croix, G. E. M. (1972), The Origins of Peloponesian War, London.

Ferguson, W. S. (1904), "The Historical Value of the Twelfth Chapter of Plutarch's Live of Pericles", TAPA 35, pp. 5-20. 
Fornara C. (1975), "Plutarch and the Megarian Decree", YCIS 24, pp. 213-228.

Frazier, F. (1989), "Remarques à propos de l'usage des citations en matière de chronologie dans les Vies", ICS 13. 2, pp. 297-309.

Guthrie, W. K. (1969), A History of Greek Philosophy, Cambridge.

Kagan, D. (1990), Pericles of Athens and the Birth of Democracy, London.

Lesky, A. (1995), História da Literatura Grega, Lisboa.

Lewis, D. M. et alii (21992), The Cambridge Ancient History, vol. V - The Fifth Century B. C, Cambridge.

Mansfeld, J. (1980), “'The Chronology of Anaxagoras' Athenian Period and the Date of his Trial, II”, Mnemosyne ser. 4 32, pp. 17-95.

Marrou, H. I. (I948), Histoire de l'Education dans l'Antiquité, Paris.

Martin JR., H. (I960), "The Concept of Praotes in Plutarch's Lives", GRBS 3, pp. 65-73.

Pelling, C. (I980), "Plutarch's Adaptation of his Source-Material”, JHS 100, pp. 127-140.

_ (1989), "Aspects of Plutarch Characterization", ICS 13. 2, pp. 257-273. 
_ (I 986), "Synkrisis in Plutarch's Lives", in F. Brenk, I.

Gallo (eds.), Miscelanea Plutarchea, Ferrara, pp. 83-96.

Pérez Jiménez, A. (1994), "Precisiones a la Doctrina de Plutarco sobre el Carácter”, in M. G. ValdÉs, (ed.), Estudios sobre Plutarco: Ideas Religiosas, Madrid, pp. 331-340.

_ (I995), "Proairesis: las Formas de Acceso a la Vida Pública y el Pensiamento Político de Plutarco", in I. Gallo, B. Scardigli (eds.), Teoria e Prassi Politica nelle Opere di Plutarco - Acti del V Convegno Plutarcheo, Napoli, pp. 363-381.

_ (I996), "La Asociación de Ideas como Criterio Formal en las Vidas Paralelas", in J. A. F. Delgado, F. P. PArdo (eds.), Estudos sobre Plutarco: Aspectos Formales. Actas del IV Simposio Español sobre Plutarco, Madrid, pp. 257-265.

Prandi, L. (1977), "I Processi contro Fidia, Aspasia, Anassagora, e l'opposizione a Pericle", Aeuum 51, pp. 10-26.

Ribeiro Ferreira, J. (1990), A Democracia Ateniense, Coimbra.

Rocha Pereira, M. H. ( $\left.{ }^{8} 1998\right)$, Estudos de História da Cultura Clássica, vol. I - Cultura Grega, Lisboa.

Sansone, D. (1989), "Notes on Plutarch: Pericles and Fabius", ICS I 3. 2, pp. 3 I I-3 I 8 
Sommerstein, A. H. (1997), "Platón, Éupolis y la comedia de demagogo", in A. López EIRE (ed.), Sociedad, Politica y Literatura Comédia Griega Antigua - Actas del I Congresso Internacional, Salamanca, pp. 183-195.

Stadter, P. A. (I975), "Plutarch's Comparison of Pericles and Fabius Maximus", GRBS 16, pp. 77-85.

_ (1989), "The proems of Plutarch Lives", ICS 13. 2, pp. 275-295.

_ (1997), "Plutarch's Lives: The Statesman as a Moral Actor", in C. Schrader, V. Ramón, J. Vela (eds.), Plutarco y la Historia. Actas del V Simposio Español sobre Plutarco, Zaragoza, pp. 65-81.

- (1992), Plutarch's and the Historical Tradition, London.

_ (1996), "Anecdotes and the Thematic Structure of Plutarchean Biography”, in J. A. F. Delgado, F. P. PArdo (eds.), Estudos sobre Plutarco: Aspectos Formales. Actas del IV Simposio Español sobre Plutarco, Madrid, pp. 291-303.

SwaIn, S. (1989), "Character Change in Plutarch", Phoenix 43, pp. $62-68$.

Wardman, A. E. (I97I), "Plutarch Methods in the Lives", CQ 21, pp. 254-261. 


\section{Estudos SOBRE FÁBIO MÁXIMO}

Cambell, B., ed. (2004), Greek and Roman Militar Writers, London and New York.

De Romilly, J. (1979), La douceur dans la pensée grecque, Paris.

Goldsworthy, A. (2007), Generais Romanos. Os homens que construiram o Império Romano (trad. de Carlos Fabiáo), Lisboa.

Guerrini, R. (1991a), "L'Ethos di Fabio. Costanti e Metamorfosi”, in A. Santoni, Plutarco. Vite Parallele - Pericle. Fabio Massimo, Milano, pp. 245-283.

_ (1991b), "Dall'exemplum alla biografia: Fabio Massimo nell'arte del Rinascimento" in A. Santoni, Plutarco. Vite Parallele - Pericle. Fabio Massimo, Milano, pp. 301-315.

Halliwell, S. (2008), Greek Laughter. A Study of Cultural Psychology from Homer to Early Christianity, Cambridge.

Elliott, J. (2009), “Ennius 'Cuntactor' and the history of a gerund in the Roman historiographical tradition", CQ 59. 2, pp. 532-542.

LEÃo, D. L. (2008), "Introdução", in D. L. LEẤ, M. C. Fialho, Vidas Paralelas. Teseu e Rómulo, Coimbra, pp. 97-108. Disponível também em formato digital: 
http://bdigital.sib.uc.pt:8080/classicadigitalia/ handle/123456789/9.

Lintott, A. (2003), The Constitution of the Roman Republic, Oxford.

Martin JR, M. (1960), "The concept of Praotes in Plutarch's Lives", GRBS 3. 2-3, pp. 65-73.

Münzer, F. (1909), “Q. Fabius Maximus, 116”, RE 6, cols. 1814-1830.

Pease, E. (2008), History of the Fabian Society. The Origins of English Socialism, Florida.

Ribeiro Ferreira, J. (2008a), "O doce afago da Philanthropia" in C. SoAres et alii, Ética e Paideia em Plutarco, Coimbra, pp. 8797. Disponível também em formato digital: http://bdigital.sib.uc.pt:8080/classicadigitalia/ handle/123456789/7.

(2008b), "Os valores de Plutarco e sua actualidade" in C. SoAres et alii, Ética e Paideia em Plutarco, Coimbra, pp. 99-120. Disponível também em formato digital: http://bdigital.sib.uc.pt:8080/ classicadigitalia/handle/123456789/7.

Rocha Pereira, M. H. ( $\left.{ }^{4} 2009\right)$, Estudos de História da Cultura Clássica, vol. 2. Cultura Romana, Lisboa.

SAÏD, S. (2004), "Plutarch and the people in the Parallel Lives", Mnemosyne Supplementum, vol. 2, pp. 7-26. 
Stadter, P. A. (1975), "Plutarch's Comparison of Pericles and Fabius Maximus", GRBS 16.1, pp. 77-85.

_ (1997), "Plutarch's Lives: The Statesman as Moral Actor" in C. Schrader, Vicente Ramón, J. Vela (eds.), Plutarco y la Historia. Actas del V Simposio Español sobre Plutarco, Zaragoza, pp. 65-81.

Sumner, G. V. (1975), "Elections at Rome in 217 a.C.”, Phoenix 29, pp. 250-9.

Von Alten, W. (1933), “Two works by Rubens”, The Burlington Magazine for Connoisseurs vol. 62 (no 358), pp. 15-7.

Williamson, G. C. (1990), Pietro Vannucci called Perugino, London.

Ziegler, K. (1951), "Plutarchos”, RE 21, col. 899. 
(Página deixada propositadamente em branco) 


\section{ÍNDICE DE NOMES}

ACaia: Per. 19.3

Acamante: Per. 3. 1.

Acrópole: Per. 3. 6; 13. 12; 32. 3.

Agamémnon: Per. 28. 7.

Agariste: Per. 3. 2.

Agatarco: Per. 13. 3.

Ágora: PeR. 5. 2: 7. 5; 16. 4; 24. 9; 28. 2.; 31. 2.

Alcibíades: Per. 20. 4; 37. 1.

Alópece: Per. 11. 1.

ALPES: FAB. 2. 1.

Ambrácia: Per. 17. 2

Anacreonte: Per. 2. 1; 27. 4.

Anaxágoras de Clazómenas: Per. 4. 6; 6. 1-3; 8. 1; 16. 7-9; 32. 2 , 5.

ÂNCIO: FAB. 2. 2.

ANdros: PER. 11. 5.

Aníbal: Per. 2. 5. Fab. 2. 2, 4; 3. 1, 3; 5. 1, 3, 5; 6. 1, 4, 5, $10 ; 7$.

$2-8$; 8. 2, 3, 4; 10. 7; 11. 1, 2, 4, 5; 12. 5-6; 13, 7; 14. 1, 5, 6;

15.1-3; 16. 3, 5, 8; 17. 1; 19. 1-3, 5; 21. 2; 22. 1-2; 23.1-3; 25. 1;

26. 1, 3, 4; 27. 1, 2. COMP. PER.-FAB. 29 (2) 2.

Antemócrito: Per. 30. 3-4.

Antístenes Socrático: Per. 1. 5.

Aqueloo: Per. 19.3.

ArCÁdios: Per. 29. 2.

Arcanânia: Per. 17. 2; 19. 3.

ArCanas: Per. 33. 4.

Arginusas: Per. 37. 6.

Argos: PER. 2. 1.

Marte: FAB. 2. 2.

Aristódico de TÂNagra: Per. 10. 8.

Aristófanes: Per. 26. 4

ACARNENSES: PER. 30.4.

Aristóteles: Per. 4. 1; 9. 2; 10. 8; 26. 3; 28. 2.

Arquidamo: Per. 8. 5; 29. 7; 33. 3, 4.

Arquíloco: Per. 2. 1; 28. 7.

Ártemon: PeR. 27. 3, 4.

ÁsIA: PER. 17. 1, 2.

Aspásia: PeR. 24. 2, 5, 6, 8, 11; 25. 1; 30. 4; 32. 1, 5. Vide Hera-Aspásia.

Atena (Higia): Per. 13. 13.

Atenas: Comp. Per/Fab. 30 (3). 4. 
Atenienses: Per. 9. 2; 10. 1; 17. 1; 20. 2; 22. 4; 23. 3; 24. 1, 6, 7 ; 26. 2 , 4; 27. 2; 28. 2, 3, 8; 29. 4-7; 33. 1, 3-4; 34. 2, 4; 35. 3; 37. 3-5; 38. 4; 39. 3. COMP. PER./FAB. 28 (1). 4; 29 (2). 3 Ática: PER. 10. 3; 22. 1, 2; 30. 3; 33. 3, 4.

Áufido: $F A B .15 .1$.

Axíoco: PER. 24. 3.

BARCA: FAB. 17. 2.

Bárbaros: Per. 9. 6; 12. 1; 15. 1; 17. 1; 19. 1; 20. 1; 28. 7. FAB. 21. 4. BeócIa: PER. 17. 2; 18. 2; 33. 5.

Bisaltas: PER. 11. 5 .

BizÂNCIO: PER. 17.2.

BRÚtia: FAB. 22. 1.

Brútios: $F_{A B}$. 21. 2, 4, 5; 22. 3, 4, 5.

ButÉON (FÁBIo): FAB. 9. 4.

CÁlCIS: PER. 23. 3.

CÁlias: Per. 24. 8.

Calícrates: Per. 13.7.

Camilo: Fab. 3. 1.

Campânia: Fab. 6. 2. Comp. PeR./Fab. 29 (2). 1.

CANAS: FAB. 9.4; 15.1.

Carino: Per. 30. 3.

Capitólio: FAB. 17. 1; 22. 8.

Cápua: Fab. 17. 4. COMP. PER./Fab. 29 (2). 1.

Cartagineses: $F_{A B} .5 .4 ; 11.1,5 ; 12.5 ; 15.1,4 ; 16.1 ; 17.2 ; 25.1$, 3; 26. 3. COMP. Per./Fab. 29 (2). 3; 30 (3). 1.

Cartago: Per. 20. 4. Fab. 25. 1; 26. 4; 27.1.

Casilino: FAB. 6. 2.

Casino: Fab. 6. 1.

Caulónia: Fab. 22. 1.

César (Augusto): Per. 1. 1.

CÉsares: Comp. Per-Fab. 30 (3).7.

Chipre: Per. 10. 8; 26. 1.

CílOn: PER. 33. 1.

Címon: PER. 5. 3; 7. 3, 4; 9. 2, 6; 10. 1-3, 5-6, 8; 11. 11; 16. 3; 28. 6; 29. 1-2. Comp. Per.-FAB. 28 (I). 2; 30 (3). 2.

Cipiâo (Cornélio): Fab. 25. 1, 2, 3, 4; 26. 1-4; 27. 1. Comp. PerFAB. 29 (2). 3.

Ciro, o Moço: Per. 24, 11, 12.

Claúdios: vide Marcelo.

Clazómenas: Per. 4.6.

CleÂndridas: PER. 22. 2, 3. 
Cléon: PeR. 33. 8; 35.5.

Clístenes: Per. 3. 2.

Colarges: Per. 3.1.

Comédia: Per. 8. 4; 24.9.

Comediógrafos: Per. 7. 8; 13. 15; 16. 1; 24.9.

Conselho: Per. 7. 5.

Corcira: Per. 29. 3.

Corcireus: Per. 29. 1.

Corebo: Per. 13. 7.

Coríntios: Per. 29. 1, 4, 6.

Cornélio: Vide Cipiáo, Lêntulo.

Coroneia (Batalha de): Per. 18. 3.

Crasso: Fab. 25. 3, 4.

Cratino: Per. 3. 5; 13. 8, 10; 24.9.

NEMESIS: PER. 3. 5.

QUIRONES: PER. 3. 5.

TRACIAS: PER. 13.10.

Critolau: Per. 7.7.

Cronos: Per. 3. 5.

DÁmon: PER. 4. 1-3.

DAMÓNIDES DE EA: PER. 9. 2.

Delfos: Per. 21. 2. Fab. 18. 3.

Delos: PER. 12. 1.

DemÉter: FAB. 18. 2.

Diógenes: FAB. 10. 2.

Diopites: PeR. 32. 2.

Dípilo (Portas): Per. 30. 3.

DórIos: PER. 17. 2.

Dracôntides: Per. 32.3.

Dúris de Samos: Per. 28. 2, 3.

EA: PER. 9. 2.

Efialtes: Per. 7. 8; 9. 5; 10. 7-8; 16. 3.

Éforo: PER. 27. 3; 28. 2.

Egina: PER. 8. 7.

Eginetas: PeR. 29. 5; 34.2.

EgÍPCIOS: PER. 37. 4.

Egipto: PeR. 20. 3.

Eleia: PER. 4. 5.

Eleio: Per. 29. 2.

ELÊUSIS: PER. 13. 7.

Elpinice: Per. 10. 5, 6; 28. 5, 7. 
Emílio (Paulo): Fab. 14. 4, 6, 7; 16. 4, 6, 8.

ENÉADAS: PER. 19. 3.

EPAMINONDAS: FAB. 27. 3.

Epidauro: Per. 35. 3.

EPÍLICo: PER. 36. 2.

Epítimo de Farsália: Per. 36. 5.

Esparta: Per. 22. 4; 23.2.

Ésquines Socrático: Per. 24. 6; 32. 5; 32.5.

EsQuinocÉfalo: PER. 3. 4.

ETA: PeR. 17. 3.

Estesímbroto de Tasos: Per. 8. 9; 14. 16; 26. 1; 36. 6.

Ética (Teofrasto): Per. 38. 2.

Etrúria: Per. 20. 4. FAB. 2. 2; 3. 1; 25. 4.

Eubeia: Per. 7. 8; 17. 3; 22. 2; 23. 3. Comp. Per./Fab. 29 (2). 1.

Eubeus: PeR. 22. 1.

Êuolis: PER. 3. 7; 24.10.

DEMOS: PER. 3. 7; 24. 10.

EURÍPIDES: $F_{A B} \cdot 17.4$.

Euriptólemo: Per. 7. 5.

Europa: Per. 17. 1.

EvÂNgelo: PER. 16. 6.

Fábio (filho de Fábio Máximo): FAB. 24.1.

FÁbio Máximo: PeR. 2. 5.

Fábios: FAB. 1. 2. Vide Butéon, Pictor.

FALÉRIOS: FAB. 2. 2.

FarsÁlia: PER. 36. 5.

Fenícios: PeR. 28. 6.

Fídias: PeR. 2. 1; 13. 6,15; 31. 2-3, 5; 32. 6.

Filémon: PER. 2. 1.

FILIPE: PER. 1. 6.

Flamínio (Gaio): Fab. 2. 3; 3. 1, 3, 5.

Fliunte: PeR. 4. 5.

FÓCIDA: PER. 17. 2.

Fócios: PER. 21. 2; 24.12.

Fódios: $F_{A B}$. 1. 2.

FóRUM: $F_{A B} .1 .8 ; 8.4 ; 9.5 ; 24.6$.

Fúlvio: Comp. Per.-Fab. 29 (2). 1.

GaLOS: FAB. 2. 3.

Gilipo: Per. 22. 4.

Gíscon: FAB. 15. 3, 4.

Glauco: Per. 31. 5. 
Grécia: Per. 7. 3; 12. 1, 2; 17. 1, 3; 22.1.

Gregos: Per. 15. 1; 17. 1; 19. 1; 20. 1; 24. 4; 29. 4.

Hades: Per. 3.7.

Hágnon: PER. 32. 4.

Helenos: PeR. 15.1.

Helesponto: Per. 17. 2.

Hestieus: PER. 23. 3.

Hera: PeR. 2. 1; 24.9.

Hera-Aspásia: Per. 24.9.

Héracles: FAB. 1. 2; 22.8.

Heraclides Pôntico: Per. 27. 4; 35. 5.

Hermipo, o comediógrafo: Per. 32. $1 ; 33.8$.

Hermótimo: Per. 24. 12.

Hipóbotas: PER. 23. 4.

Hipónico (pai de Cálias): Per. 24. 8.

Homero: FAB. 19. 2.

IBERos: FAB. 7. 2.

ICTINO: PER. 13. 7.

Idomeneu de LÁmpsaco: PeR. 10. 7; 35.5.

ÍON DE QuiOs: PER. 5. 3; 28.7.

Iónios: PER. 17. 2; 24. 3; 28.7.

ISMÉNIAS: PER. 1.5.

ItÁlIA: PER. 11. 5; FAB. 2. 1-2; 4. 6; 5. 6; 8. 4; 14. 6; 17. 3-4; 19. 1; 23. $1 ; 25.1,2 ; 26.1,4 ; 27.2$.

ItÁGenes: PER. 26. 2.

JúNio (MARCo): FAB. 9. 4.

LACEDEMÓNIA: 30.1.

Lacedemónios : PeR. 8. 5; 9. 6; 10. 1, 4; 17. 1, 4; 21. 1, 2; 22. 1, 3;

24.1; 29. 1, 5, 7; 30. 2, 5; 31. 1; 33. 1, 4. COMP. PER/FAB. 30 (3). 1.

Lacrátidas: PeR. 35.5.

LÂMACO: PER. 20. 1.

LÂMPON: PER. 6. 2-3.

LeMnos: PeR. 25. 2.

Lêntulo (Cornélio): Fab. 16. 7, 8, 9.

Leócrates: Per. 16. 3; Comp. Per.-Fab. 30 (3). 3.

Lesbos: PeR. 17. 2.

Líbia: FAB. 8. 4; 25. 1; 26. 3-4.

LÍGURES: FAB. 2.1.

LÍsICLES: PER. 24. 6.

Lívio (Marco): Fab. 23. 3.

LÓCRIDA: PER. 17. 2. 
Lótrono: FAB. 6. 2.

LUCANO: FAB. 20. 5-7.

Malíaco (Golfo): Per. 17. 3.

MÂNLIO: VIDE Torquato.

Marcelo (Claúdio): Fab. 19. 1, 4-6; $22.1,8$.

Marso: FAB. 20. 2.

MÁximo: vide Ruliano.

Mégara: Per. 19. 2; 29. 7; 30. 3, 4; 34. 3.

Melisso: PER. 26. 2-3; 27.1.

MenéXeno: Per. 24.7.

Menipo: Per. 13. 15.

MÉnon: PER. 31. 2, 5.

Medos: Per. 28. 6.

Megarenses: Per. 22. 1; 29. 4, 8; 30. 2-4.

Metágenes de Xípeto: Per. 13. 7.

Metaponto: $F A B$. 19. 7.

Metílio: FAB. 7. 5; 8. 4; 9. 2.

Mícale: PER. 3. 2.

Mileto: PeR. 24. 1.

MilésIos: PeR. 25. 1; 28. 2.

Milto: PeR. 24. 11.

Minúcio Rufo (Marco): FAB. 4. 1; 5. 5; 7. 5; 8. 1, 4; 9. 1-3; 10. 1, 4-7; 11. 3, 5, 6; 12. 2-4; 13. 1, 7. COMP. PER-FAB. 29 (2). 2; 30 (3). 2.

Mirónides: PER. 13. 12.

MNÉSICLES: PER. 13.12.

Musas: PER. $1.5 ; 11.4$.

"Novos Pisistrátidas": Per. 16. 1.

Naxos: PER. 11. 5.

Nemeia: Per. 19. 2.

NúMIDAS: FAB. 11. 7; 12. 4; 26. 3.

Olímpico (Péricles): Per. 8. 3; 39. 2.

Ônfale (Aspásia): Per. 24. 9.

OVICULA (CORDEIRINHO): FAB. 1. 4.

PÁralo: Per. 24. 8; 36. 8.

Parménides de Eleia: Per. 4. 5.

Paulo: vide Emílio.

Pegas: Per. 19. 2.

Peloponésios : Per. 22. 1-2; 29. 1; 33. 3, 5; 34. 1; 37.6.

Peloponeso : Per. 8. 7; 17. 2, 4; 19. 2; 29. 1; 33.5; 34. 1, 3.

Periforeto: Per. 27. 3, 4. 
Pictor (FÁbio): FAB. 18. 3.

Pireu: PER. 8. 7.

Pirilampes: PeR. 13. 15.

Pirónides: PeR. 24. 10.

PISA: PER. 2. 1.

Pisistrátidas: Per. 3. 2. Vide "Novos"

Pisístrato: Per. 7. 1.

Pissutnes: PeR. 25. 3, 4.

Pitoclides de Ceos: Per. 4.1.

Platáo: Per. 7. 8; 8. 2; 15. 2; 24.7.

Platáo, o Cómico: Per. 4.4.

Plistóanax: Per. 22. 1-2.

Plutarco:

CIMON: PER. 9. 6.

LISANDRO: PER. 22. 4.

MARCELO: FAB. 19. 2; 22. 8.

Poetas Áticos: PeR. 3. 4.

Polialces: PER. 30. 1.

Policleto: Per. 2. 1.

Polícrates de Samos: Per. 26. 4.

Pompónio: FAB. 3. 4.

Ponto: PeR. 20.1.

Posidónio de Apameia: Fab. 19. 4.

Potideia: Per. 29. 6.

Priene: PeR. 25. 1.

Protágoras: Per. 36. 5.

Quersoneso: Per. 11. 5: 19. 1.

RÉGIO: FAB. 22. 1.

Rodes: PER. 17. 2

Roma: PER. 1. 1. FAB. 1. 2; 2. 2; 7. 5, 7; 8. 4; 9. 4; 17. 4, 6; 24. 4; 26. 3-4; 27. 1. СоMP. PER./FAB. 30 (3). 7.

Romanos: $F_{A B} .2 .4 ; 3.5 ; 6.9 ; 7.2 ; 11.6 ; 12.1$, 4-5; 14. 3; 16. 1-3,

9; 19. 4; 23. 1, 3; 24. 1, 5; 25. 1; 26. 2; 27. 3. COMP. PER/FAB. 28

(1). $5 ; 29$ (2). 2, 3; 30 (3). 4.

Ruliano (FÁbio Máximo): FAB. 1. 3.

SAmos: PeR. 8. 9; 24. 1, 2; 25. 2; 26. 2, 4; 27. 4; 28. 4. COMP. PER./ FAB. 29 (2). 1.

SÂmios: PER. 25. 1, 3; 26. 1-2, 4; 28. 1-2, 7.

Síbaris: Per. 11. 5.

Sícilia: PER. 20. 4; 22. 4. FAB. 22. 1; 26. 2.

SiCIÓNIOS: PER. 19. 2. 
Simeta: PeR. 30. 4.

Símias: PER. 35. 5.

SinOpe: PER. 20. 2.

Sinópios: PER. 20. 1, 2.

Sócrates: PER. 13. 7; 24.5.

Sófocles: PeR. 8. 8.

TÂNagra: PER. 10. $1,8$.

Targélia: Per. 24. 3-4.

TARentinos: $F A B .21 .1-2,5 ; 22.3-7 ; 23.1,3,4$.

Tarento: Fab. 21. 1; 22. 2, 8; 23. 3. Comp. Per./Fab. 29 (2). 1.

Tebanos: FAB. 27. 3.

Teofrasto: Per. 23. 2; 35. 5; 38. 2.

Teleto: Per. 33. 8.

Tessália: PER. 17. 3.

Tessalo: Per. 29. 2.

Tibre: FAB. 1. 2.

Timesilau: PER. 20. 1.

Timon de Fliunte: Per. 4. 5.

Tisandro: Per. 36. 2.

Tólmides, o de Tolmeu: Per. 16. 3; 18. 2-3; 19. 2. Comp. Per-FAB. 28 (1). $2 ; 30$ (3). 3.

Tolmeu: Per. 18. 2.

Torquato (MÂnlio): Fab. 9. 2.

Trácia: PeR. 11. 5; 17. 2.

TrácIOS: PER. 19. 1.

TRÁgia: PER. 25. 5.

TRASIMENO: FAB. 3.1.

TrébIA: FAB. 2. 2; 3.4.

Triásias (Portas): Per. 30. 3.

Tucídides, filho de Melésias: Per. 6. 2-3; 8. 5; 11.1 ; 14. 1, 3; 16.

3. Comp. PER -FAB. 30 (3). 2.

Tucídides: PeR. 9. 1; 15. 3; 16. 1; 28. 2, 8; 33. 1. FAB. 1.9.

TÚRIOS: PER. 11. 5.

VArráo (Terêncio): FAB. 14. 2, 4-6; 15. 1; 16. 6, 8; 18.4.

Venúsia: $F A B$. 16. 6.

Verrugoso: FAB. 1. 4.

Volturno: Fab. 6.1.

Xantipo (pai de Péricles): Per. 3. 2.

Xantipo (filho de Péricles): Per. 24. 8; 36. 2, 4, 6.

Xénocles de Colarges: Per. 13.7.

XerXes: PER. 3. 2; 10. 5; 13.9. 
Zenáo de Eleia: Per. 4. 5; 5. 3.

Zeus/Júpiter: Per. 2. 1; 3.5. 
(Página deixada propositadamente em branco) 


\section{Volumes publicados na Colecção Autores \\ Gregos e LATINOS - SÉrIE TeXtos}

1. Delfim F. Leão e Maria do Céu Fialho: Plutarco. Vidas Paralelas - Teseu e Rómulo. Traduçáo do grego, introdução e notas (Coimbra, CECH, 2008).

2. Delfim F. Leão: Plutarco. Obras Morais - O banquete dos Sete Sábios. Tradução do grego, introdução e notas (Coimbra, CECH, 2008).

3. Ana Elias Pinheiro: Xenofonte. Banquete, Apologia de Sócrates. Tradução do grego, introdução e notas (Coimbra, CECH, 2008).

4. Carlos de Jesus, José Luís Brandão, Martinho Soares, Rodolfo Lopes: Plutarco. Obras Morais - No Banquete I-Livros I-IV. Tradução do grego, introdução e notas. Coordenação de José Ribeiro Ferreira (Coimbra, $\mathrm{CECH}, 2008)$.

5. Ália Rodrigues, Ana Elias Pinheiro, Ândrea Seiça, Carlos de Jesus, José Ribeiro Ferreira: Plutarco. Obras Morais - No Banquete II - Livros V-IX. Tradução do grego, introdução e notas. Coordenação de José Ribeiro Ferreira (Coimbra, CECH, 2008).

6. Joaquim Pinheiro: Plutarco. Obras Morais - Da Educação das Crianças. Tradução do grego, introdução e notas (Coimbra, CECH, 2008).

7. Ana Elias Pinheiro: Xenofonte. Memoráveis. Tradução do grego, introdução e notas (Coimbra, $\mathrm{CECH}$, 2009). 
8. Carlos de Jesus: Plutarco. Obras Morais - Diálogo sobre o Amor, Relatos de Amor. Tradução do grego, introdução e notas (Coimbra, CECH, 2009).

9. Ana Maria Guedes Ferreira e Ália Rosa Conceição: Plutarco. Vidas Paralelas - Péricles e Fábio Máximo. Tradução do grego, introdução e notas (Coimbra, $\mathrm{CECH}, 2010)$. 
(Página deixada propositadamente em branco) 


\section{OBRA PUBLICADA}

COM A COORDENAÇÁO

CIENTÍFICA

○

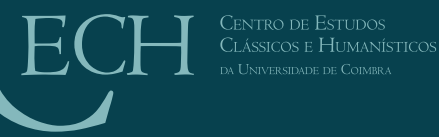

